BUDAPESTI CORVINUS EGYETEM

SZOCIOLÓGIA DOKTORI ISKOLA

\title{
ERDÉLYI MAGYAR EGÉSZSÉGÜGYI DOLGOZÓK MAGYARORSZÁGRA VÁNDORLÁSA
}

\author{
Doktori értekezés
}

Pitó Klára

Budapest, 2015 


\section{Tartalomjegyzék}

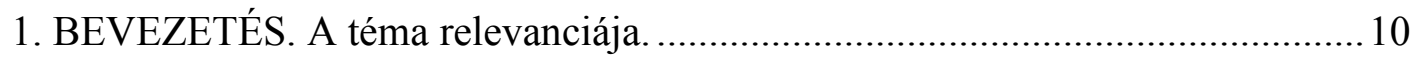

2. A NEMZETKÖZI MIGRÁCIÓ ELMÉLETEI................................................. 13

2.1. A migráció push és pull tényezőkre alapozó makro- és mikro elméletei ..... 13

2.1.1. A neoklasszikus közgazdaságtan makro- és mikroszintű elméletei ....... 14

2.1.2. Az új közgazdaságtan munkaerö-migrációs elmélete .......................... 15

2.2. Világrendszer és globalizációs elméletek .............................................. 15

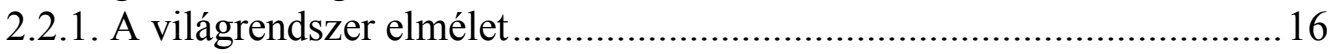

2.2.2. A duális munkaerőpiac elmélete ....................................................... 17

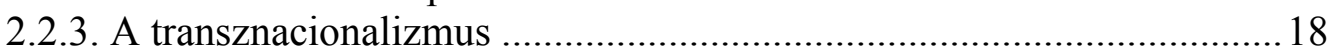

2.3. A migrációs folyamatok fennmaradásának elméletei ................................22

2.3.1. Migráns hálózatok és intézmények elméletei .....................................22

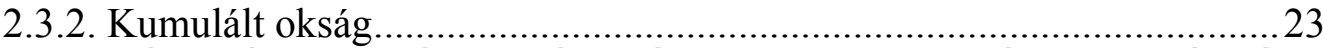

3. DIPLOMÁS VÁNDORLÁS: EGÉSZSÉGÜGYI DOLGOZÓK MIGRÁCIÓJA

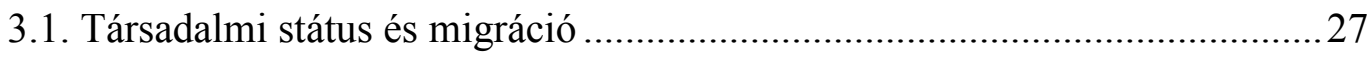

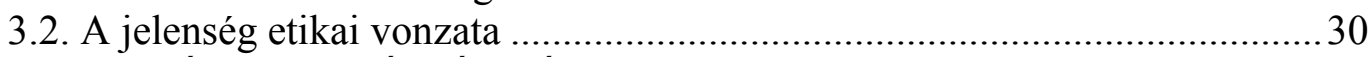

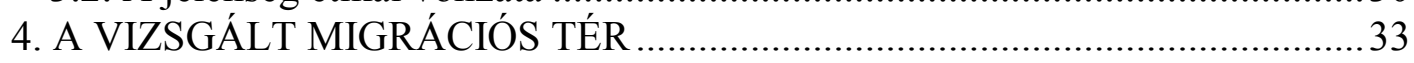

4.1. Migrációs folyamatok és politikák a globalizáció korában.......................... 33

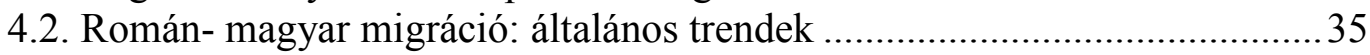

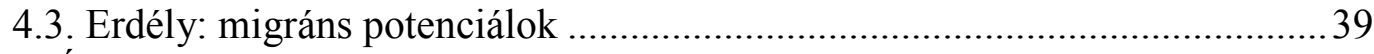

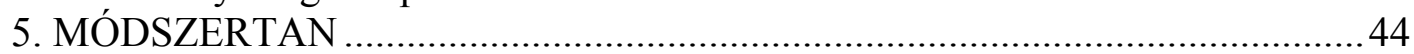

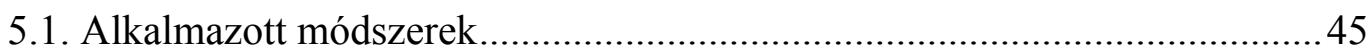

5.1.1. Statisztikai adatok: nyilvántartások ............................................... 45

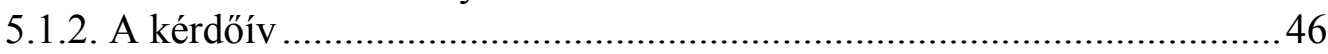

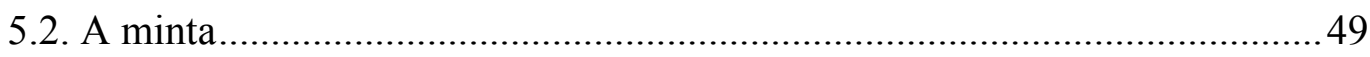

5.2.1. Egészségügyi képzés és a képzésben résztvevő csoportok Romániában.

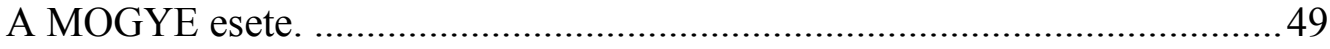

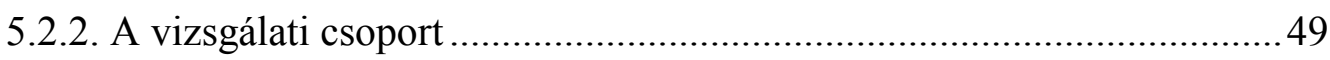

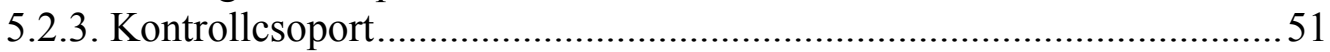

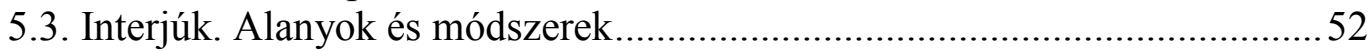

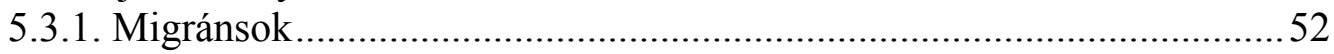

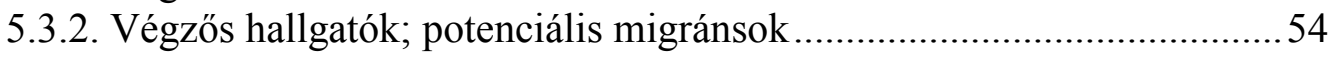

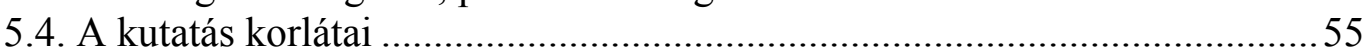

6. EGÉSZSÉGÜGYI DOLGOZÓK A MIGRÁCIÓS TÉRBEN ...........................57

7. MIGRÁNS NARRATÍVÁK - DÖNTÉSI MECHANIZMUSOK .....................6 67

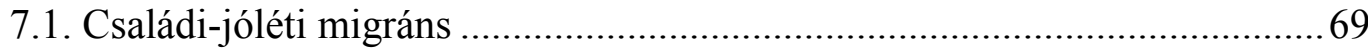

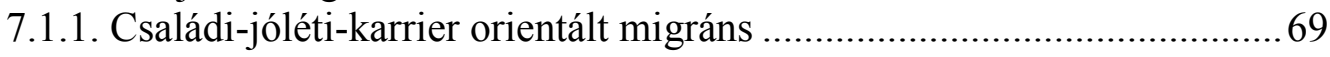

7.1.2 Családi-jóléti-nem karrier orientált migráns ...................................... 75

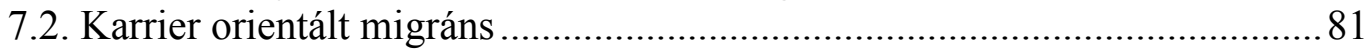

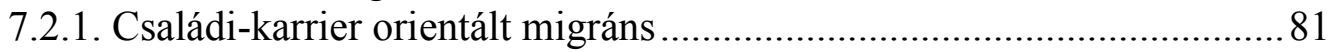

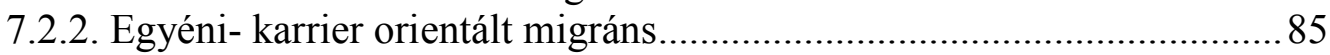

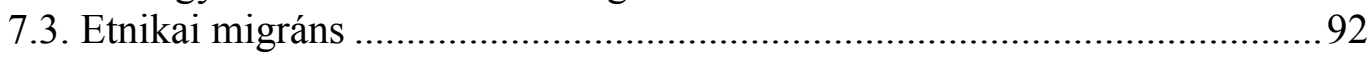

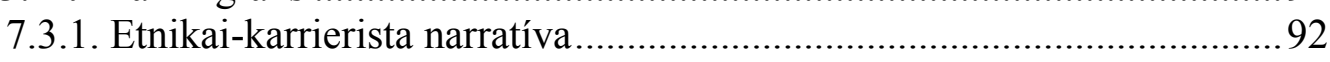

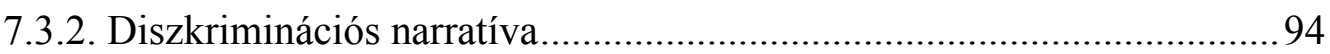

8. AZ ERDÉLYI, MAGYAR NYELVEN TANULÓ VÉGZŐS ORVOS-, GYÓGYSZERÉSZ ÉS NŐVÉR HALLGATÓK MIGRÁCIÓS POTENCIÁLJA. A KÉRDÖÍVES KUTATÁS EREDMÉNYEI A VIZSGÁLATI CSOPORTBAN .. 100 
8.1. Nyers migrációs potenciál 100

8.1.1. A migrációs potenciált általában befolyásoló szociodemográfiai tényezők és azok hatásai.

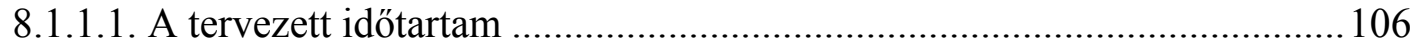

8.1.2. A kapcsolati tőke szerepe a külföldi munka tervezésében ................... 108

8.1.3. Idegennyelv- ismeret: a humán tőke hatásai...................................... 112

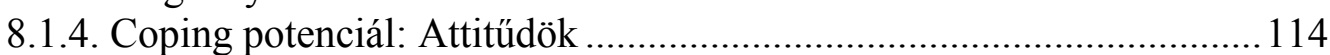

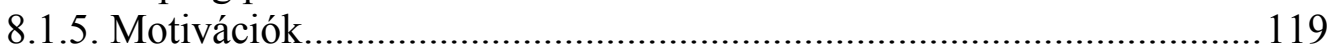

8.1.6. Összkép a befolyásoló tényezőkröl: a logisztikus regresszióelemzés eredményei

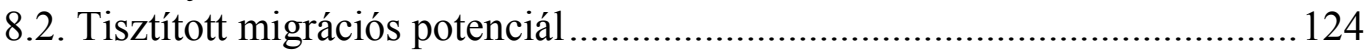

8.3. Ellen-motivációk, azaz helyben tartó tényezők ...................................... 127

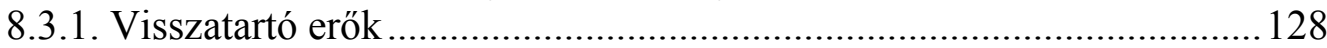

8.3.2. A maradás feltételei ............................................................................ 129

9. A MOGYE VÉGZÖS ROMÁN ÉS MAGYAR NYELVEN TANULÓ HALLGATÓI KÖZÖTTI MIGRÁCIÓS POTENCIÁL ÖSSZEHASONLÍTÁSA.

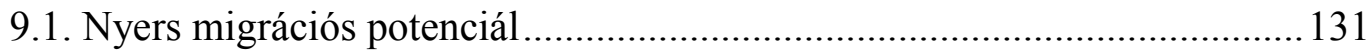

9.1.1. Szociodemográfiai tényezők szerinti összehasonlítás .......................... 132

9.1.2. Kapcsolati tőke szerepe a külföldi munka tervezésében ..................... 134

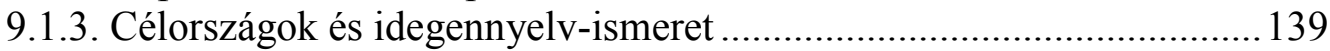

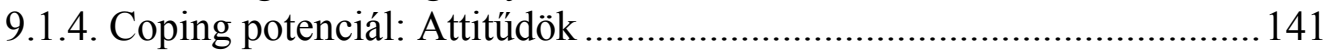

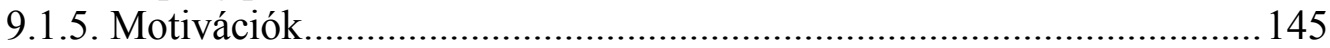

9.1.6. Újabb összkép: a logisztikus regresszióelemzés modelljei ................. 147

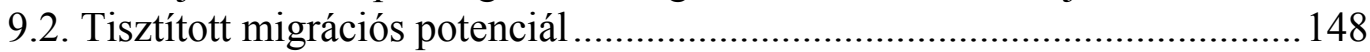

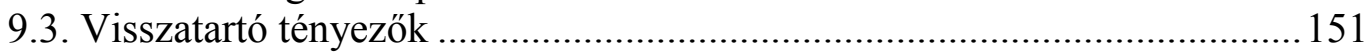

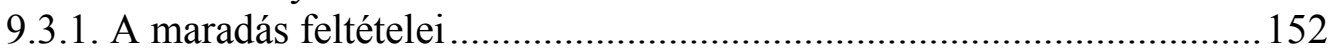

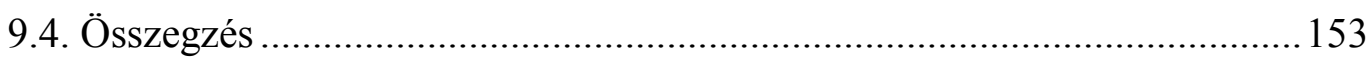

10. MIGRÁCIÓS POTENCIÁL AZ INTERJÚK FÉNYÉBEN .......................... 159

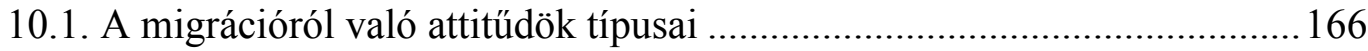

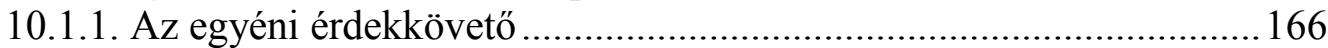

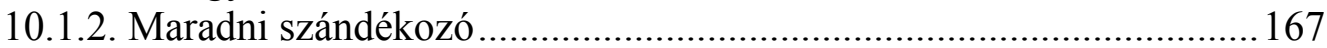

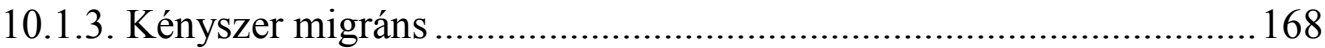

10.2. Összegzés: a migrációról való gondolkodás és a „befejezett” migráció

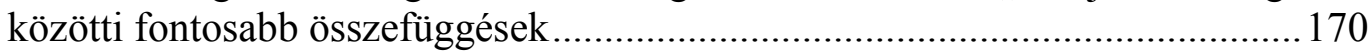

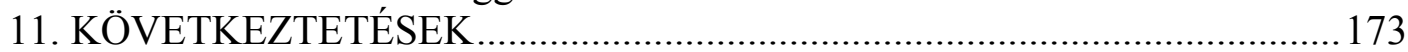




\section{Táblázatok és ábrák jegyzéke}

1. táblázat: Az alapsokaság és a „mintába” került vizsgálati csoport megoszlása intézmény szak és nem szerint

2. táblázat: Romániai egészségügyi dolgozók Európában: néhány célország statisztikája

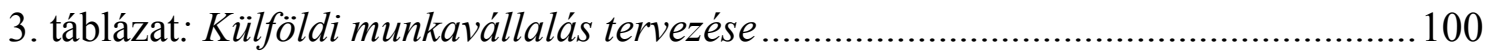

4. táblázat. A szociodemográfiai tényezök hatása a migrációs tervekre ........................ 102

5. táblázat: Kapcsolati tőke szerepe a migráció tervezésében ..................................... 108

6. táblázat: A migráns kapcsolat típusa és hatása a munkavállalási tervekre ............... 108

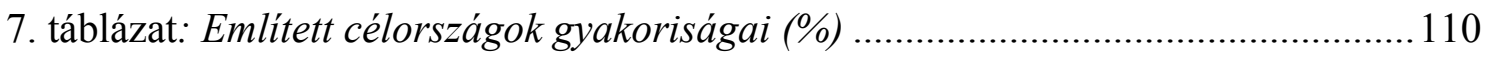

8. táblázat: Származás hatása az idegennyelv-ismeretre ............................................. 112

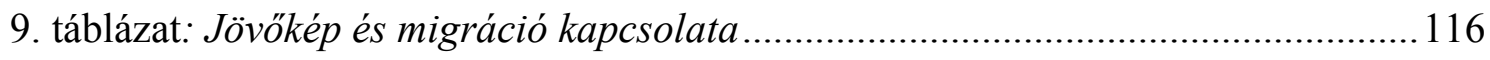

10. táblázat: A migrációs motivációk rangsora és emlitésük relatív gyakorisága ......... 120

11. táblázat: A nyers migrációs potenciált befolyásoló tényezök (a logisztikus regresszió

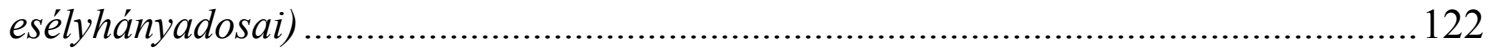

12. táblázat: Megtett lépés(ek) a migrációs terv megvalósitása érdekében ................... 125

13. táblázat: A tisztított migrációs potenciált befolyásoló tényezök (a logisztikus

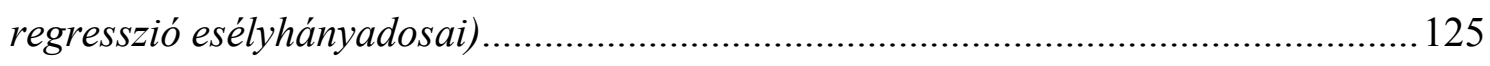

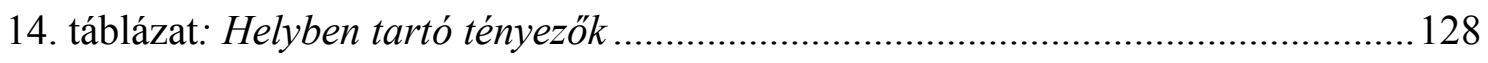

15. táblázat: A külföldi munkát tervezök aránya a szülők foglalkozása szerint (\%) ......133

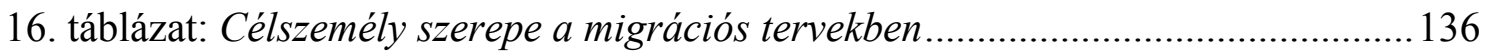

17. táblázat: A vándorlás tervezett ideje a vizsgálati- és kontrollcsoportban (\%)........ 138

18. táblázat: Nyelvtudás és külföldi munkavállalás tervezése közötti kapcsolat............140

19. táblázat: Szakmai képzéssel való elégedettség és a külföldi munka tervezése közötti összefüggés

20. táblázat: Migrációs motivációk rangsora a vizsgálati- és a kontrollcsoportban .... 146 21. táblázat: A külföldi munkavállalási terveket befolyásoló tényezők hatása a nemzetiség (nyelv)kontroll alatt tartásával.

22. táblázat: A külföldi munkavállalás érdekében megtett lépések relatív megoszlása a vizsgálati és kontrollcsoportban (\%)

23. táblázat: Az igénybe vett vagy potenciális információforrások relativ megoszlása a viszgálati-és a referenciacsoportban (\%)

24. táblázat: A külföldi munkavállalási tervek megvalósulásának esélyei a nemzetiség (nyelv) változó bevonásával 150 
1. ábra: Magyarország és Románia gazdasági fejlettsége 1988- 2013 közötti időszakban $\left(G D P / f^{\prime \prime}\right)$

2. ábra: A romániai migránsok fó célországainak gazdasági fejlettsége (GDP/fö) )........38

3. ábra: Az 1000 före jutó egészségügyi dolgozók száma négy európai országban 2010ben

4. ábra: A Romániából Magyarországra érkezö egészségügyi dolgozók száma, a honositások és elismertetések alapján

5. ábra: Romániából Magyarországra érkezö bevándorlók számának alakulása 66

6. ábra: A külföldi munkavállalás tervezett idötartamának relatív gyakorisága a hallgatott szak függvényében 106

7. ábra: A külföldi munkavállalás tervezett idötartama a szülök szubjektív anyagi helyzetének függvényében (relatív gyakoriság)

8. ábra: A leggyakrabban megjelölt célországok a migráció tervezett ideje függvényében

9. ábra: Idegen nyelvü média fogyasztása és a migráció tervezése közötti kapcsolat (relatív gyakoriságok)

10. ábra: Jövővel kapcsolatos attitüdváltozók átlagértékei a hallgatott szak függvényében.

11. ábra: Eddigi élettel való elégedettség és a migráció tervezése (relatív gyakoriságok)

12. ábra: Migrációs motivációk relatív gyakorisága a hallgatott szak alapján.

13. ábra: A szakmai képzéssel való elégedettség és a migráció okai közötti összefüggések (relativ gyakoriságok)

14. ábra: A maradás feltételeiként leggyakrabban megnevezett tényezők

15. ábra: Külföldi munkavállalás tervezése a vizsgálati és referenciacsoportban 131

16. ábra: Baráti/ ismerősi kapcsolatok a célországokban a vizsgálati és kontrollcsoportban (relatív gyakoriság).

17. ábra: Emlitett célországok a vizsgálati és kontrollcsoportban (\%) 137

18. ábra: Eddigi élettel való elégedettség hatása a migráció tervezésére (\%) 145

19. ábra: A maradás feltételeiként említett tényezők relatív gyakoriságai a vizsgálati és a kontrollcsoportban

\section{Mellékletek jegyzéke}

1. melléklet: Vizsgálati csoport súlyai

2. melléklet: Referenciacsoport súlyai

3. melléklet: Kérdöív 
4. melléklet: Átlagos éves bérek a célországokban (1990-2013).................................202

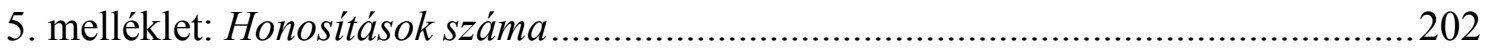

6. melléklet: MOGYE-n végzett magyar tannyelvü hallgatók (asszisztensek nélkül) és a

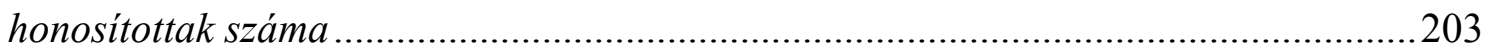

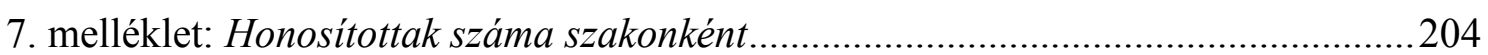

8. melléklet: Származás hatása a migrációs tervekere a vizsgálati- és referencia

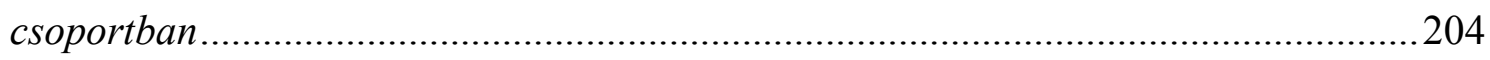

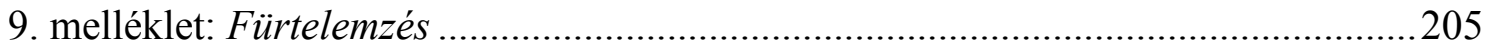

10. melléklet: Migráns interjúalanyok jegyzéke ......................................................208

11. melléklet: Végzős hallgatók interjúalanyainak jegyzéke .....................................208

12. melléklet: A témában közölt saját publikációk .....................................................209

\section{Rövidítések jegyzéke}

DPR: Diplomás Pályakövetési Rendszer

EEKH: Egészségügyi Engedélyezési és Közigazgatási Hivatal

EMK: Egészségügyi Menedzserképző Központ (SOTE)

EU: Európai Unió

GDP: Gross Domestic Product

MESZK: Magyar Egészségügyi Szakdolgozói Kamara

MOGYE: Marosvásárhelyi Orvosi és Gyógyszerészeti Egyetem

MOHPROF: Mobility of Health Professionals project (2007-2013)

MOK: Magyar Orvosi Kamara

NKI: Nemzeti Kisebbségkutató Intézet (Kolozsvár)

OECD: Organisation for Economic Co-operation and Development

SEEMIG: South East European Migration project

SOTE: Semmelweis Orvosi Tudományegyetem

USA: Amerikai Egyesült Államok

WHO: World Health Organization 


\section{BEVEZETÉS. A téma relevanciája.}

Az orvosok és más egészségügyi dolgozók tömeges nemzetközi vándorlása korunk jelentős társadalmi kérdése és problémája. A nemzetközi migráció egy olyan sajátos formáját jelenti, amely növekvő fontosságra tesz szert a kormányzati és nemzetközi migrációs-, egészségügyi és munkaerő-piaci politikákban, a szociológiai és interdiszciplináris migrációs kutatásokban, illetve a médiában megjelenő diskurzusokban. A nemzetközi vándorlást nemcsak a migrációs politikák befolyásolják, hanem a más országokban levő munkaerőpiacok struktúrája és a munkaerő-kereslet, a bérkülönbségek és egyenlötlenségek, a társadalmi biztonság és konfliktus meg a közpolitikák együttesen hatást gyakorolnak a migrációra (de Haas 2011).

A figyelem középpontjába kerülését számos, egymásra épülő tényezőnek köszönheti. Elsősorban maga a nemzetközi migráció a növekvő volumenével és kétirányú hatásaival egyre több kutató és döntéshozó érdeklődését keltette fel az elmúlt évtizedekben (Kaelin 2011; Levatino \& Pecoud 2012; Lahav \& Lavenex 2013). Ennek köszönhetően a migrációs szakirodalom jelentősen gazdagodott. Másodsorban a jóléti államok részéről megmutatkozó ambivalens bevándorlási politikák szintén figyelemfelkeltő szerepet játszottak/ játszanak. Míg a társadalmi és kulturális integráció megőrzése érdekében szigorú kontrollt gyakorolnak határaik felett, ugyanakkor munkaerő-keresletük kielégítésére törekedve (a képzési költségek befektetése nélkül), továbbá bizonyos érdekcsoportok nyomására, megkülönböztetett bánásmódban részesítik a munkamegosztási hierarchia alján (szakképzetlen munkaerő) és csúcsán (magasan képzett vagy szakértői réteg) levőket (de Haas 2011; Castles \& Miller 2009; Lavenex 2008; Levatino \& Pecoud 2012).

Mindebből látható, hogy egy olyan globális, sokrétü, ugyanakkor állandóan változó, dinamikus folyamat és probléma, amelynek leírása, magyarázata és kezelése egyfelöl interdiszciplináris megközelítést - makroszinten a különböző társadalomtudományi területek kutatóinak összefogását -, másfelől a különböző országok döntéshozóinak együttmüködését és időben a hosszú távú tervezést igényli (Favell et al. 2008; Bose 2012; Lahav \& Lavenex 2013).

A migráció-kutatásokban elengedhetetlen a különböző elemzési szintek ötvözése: az egyéni, mikroszintű motivációk, döntések és cselekvések az adott gazdasági és társadalmi viszonyokba ágyazottak. Jóllehet egyéni szinten a migráció egy személyes döntés eredményeként jelenik meg, a nagy volumenü vándorlási 
áramlatokban maga a migráció lehetősége is társadalmilag megalkotott, ezért szükséges mind a mikro-, mind a makroszinten ható tényezők figyelembe vétele (Gödri 2005; Sassen 2007).

A határon túl élő magyarok - és így az Erdélyben ${ }^{1}$ élők is - migrációs potenciálja több szociológiai kutatás tárgyát képezte, ${ }^{2}$ viszont ezek nem foglalkoztak specifikusan az általam vizsgált csoporttal. Ám arra alkalmasnak bizonyultak, hogy a kutatás tervezését módszertanilag elősegítsék, továbbá a majdani egészségügyi dolgozók migrációs potenciáljának értékelésekor egyfajta összehasonlítási alapot nyújtsanak. Másfelől az is igaz, hogy az itt leírt kutatással és annak előkészítésével egy időben több más helyi és főként nemzetközi kutatás zajlott és folyik. Az egyik kifejezetten az általam is vizsgált egyetem végzettjeinek Magyarországra vándorlását dolgozza fel; jóval nagyobb időtávot foglal magában, időben több évtizedre kiterjed, de hiányzanak a 'friss' adatok belőle, és csak az orvosok és fogorvosok migrációjára fókuszál (Ábrám 2011). Némely eredménye viszont ezt a kutatást is inspirálta. ${ }^{3}$

A különböző nemzetközi kutatások (az EU keretein belül megvalósuló WHO, OECD kezdeményezésü programok, mint pl. a MoHProf) elsősorban az egyes országokra koncentrálnak, így betekintést nyújtanak a romániai egészségügyi szakmunkaerő migrációs folyamataiba, ${ }^{4}$ viszont nem tesznek különbséget az egyes országokon belül élő nemzetiségek között. Ily módon nem alkalmasak az erdélyi magyar egészségügyi dolgozók vándorlásának tanulmányozására, viszont megteremtik a tágabb kontextust és összehasonlítási alapot, melyek segítségével megvizsgálható, hogy vannak-e a magyarok migrációjának sajátosságai, hiszen a különböző strukturális feltételek többékevésbé azonosak mindkét nemzetiségű csoport esetében.

Az értekezés alapjául szolgáló kutatás alapkérdése, hogy hogyan terveznek bekapcsolódni és mozogni a jövőbeni erdélyi egészségügyi dolgozók a fennálló migrációs áramlatokba? Mekkora a migrációs potenciál? További kérdései, hogy: melyek a vándorlási folyamatba való belépés motivációi, belső mechanizmusai? Melyek a választott célországok és tagjaik-e azok irányába mutató migráns hálózatoknak? Kik

\footnotetext{
${ }^{1}$ Erdély alatt a teljes Romániához csatolt földrajzi területet értem, nem csak a szük értelemben vett történelmi Erdélyt. Ebből következik, hogy az 'erdélyi magyar' megnevezés is tág fogalom, egyfajta szinonimája a romániai magyarnak. (A kettő közötti identitásbeli különbség fejtegetése meghaladja az értekezés kereteit).

2 Többek között: (Sik 1993; Gödri 2004; Kiss \& Csata 2004; Gödri \& Tóth 2005; Örkény 2003; Sik \& Simonovits 2003; Gödri \& Kiss 2009)

${ }^{3}$ Ennek és a további kutatásoknak a részletesebb bemutatására a továbbiakban kerül majd sor (lásd a 6. fejezetben).

${ }^{4}$ Legalábbis kísérletet tesznek egy általános kép felvázolására. A hiányos adatok és gyakori feltételezések nagyon eltérö eredményekhez vezethetnek a különböző kutatások esetében (Rohova 2011).
} 
és milyen időtávra tervezik a migrációt? Mely tényezők állnak a helyben maradás szándéka mögött? Követik-e az általános mintákat: a romániai egészségügyi dolgozók, illetve az erdélyi magyarság migrációjára jellemző trendeket?

A jelenség sokoldalúságának megragadására törekedve a trianguláció módszerével éltem, ötvözve a kvantitatív és kvalitatív módszereket.

A makroszintü elemzésben az Erdélyből átvándorolt egészségügyi dolgozók számát tartalmazó statisztikai adatok révén a folyamatnak az időbeni alakulását (a rendszerváltást követően, 1990-2012 közötti időszakban) és mintázatát próbáltam ábrázolni. Ám az összegyüjtött adatsorok nagyon hiányosak, amelyekkel kapcsolatban súlyos megbízhatósági problémák is felmerültek ${ }^{5}$ - a migrációs adatokat általában jellemző érvényességi problémákon túl. ${ }^{6}$ A mikro tényezők feltárása - mint a migráció motivációi, a vándorlást elősegítő tőkék, döntési mechanizmusok és dilemmák narratív interjúk révén történt.

A kutatás magvát a migrációs potenciál vizsgálat képezi, amely standardizált kérdőív segítségével méri az erdélyi magyar végzős orvostan, fogorvos, gyógyszerész és nővér hallgatók migrációs szándékát. A kvantitatív adatok finomítása, a belső mechanizmusok jobb megértése, továbbá egyfajta visszacsatolási kapcsolat megteremtése végett félstrukturált interjúkat is készítettem a végzősökkel. Ezek tovább gazdagítják és árnyalják a statisztikai összefüggésekből nyert képet, illetve lehetővé teszik - a narratív interjúkkal való összevetés révén - a migrációs folyamat két különböző szakaszában, a tervezésében és a vándorlás megvalósításában szerepet játszó tényezők közötti összefüggések vizsgálatát.

Jelen disszertáció fókuszában csupán két ország áll, nem vállalkozom a jelenség komplex felderítésére, mert a mindennemü rendelkezésemre álló erőforrás sokkal korlátozottabb annál, semhogy a problémát a maga teljességében bemutathatnám. Mindazáltal remélem, hogy az értekezés alapjául szolgáló kutatás eredményei rávilágítanak és segítenek megérteni olyan jelenségeket és folyamatokat, amelyek - bár a nagy egésznek csak egy kis szeletét képezik, számunkra mégis különös horderővel bírnak - mindeddig többnyire feltáratlanul, inkább csak a feltételezések szintjén húzódtak meg.

\footnotetext{
${ }^{5}$ Bővebben lásd a 6 . fejezetet.

${ }^{6}$ Lásd pl. (Gárdos \& Gödri 2014).
} 


\section{A NEMZETKÖZI MIGRÁCIÓ ELMÉLETEI}

A migrációs szakirodalom nagyon szerteágazó és sokrétű. Ez magában foglalja különböző irányzatok, megközelítésmódok, fogalmi rendszerek létezését és sokféleségét, mivel a migrációs folyamatok fejlődésével és változásaival párhuzamosan a migrációs kutatások kérdései és témakörei is módosultak. Egyes elemzők szerint lehetetlen egy egységes elmélet megalkotása (Portes et al. 1999), bár az utóbbi időben egyre többen szorgalmazzák egy egységesebb fogalomrendszer megalkotását, illetve olyan irányú törekvések is megjelentek, melyek a használatban levő makro- és mikroszintü fogalmakat egy általános keretbe próbálják beilleszteni, keresve a közös kapcsolódási pontokat (de Haas 2011). Az elméletek torzak és töredékesek abban az értelemben, hogy a vándorlás egy-egy aspektusára helyezik a hangsúlyt, és a folyamat bizonyos jellemzőire fókuszálva, a többit természetszerüen elhanyagolják vagy éppenséggel mellőzik. Viszont az egyén migrációs döntése és a döntési mechanizmusban szerepet játszó, valamint a vándorlást fenntartó tényezők annyira összetettek és képlékenyek, hogy nem írhatók le egydimenziósan, csupán egyetlen modell segítségével (Gödri \& Tóth 2005). A makroszintű elméletek föként strukturális okokkal, a mikroszintü megközelítések pedig az egyén döntésében szerepet játszó tényezők felderítésével nyújt magyarázatot a vándorlásra (Gödri \& Tóth 2005). Ebből kifolyólag a döntéshozási és migrációs áramlatok kialakulásának és fennmaradásának leírásához több elmélet fogalom- és eszköztára szükséges. A fejezet röviden áttekinti a téma kapcsán releváns elméleteket.

\subsection{A migráció push és pull tényezőkre alapozó makro- és mikro elméletei}

A migrációs elméletek kialakulásának kezdetén a közgazdaságtan modelljei voltak az uralkodó elméletek, amelyek a funkcionalista paradigmából erednek és leginkább Ravenstein nevéhez köthetők, aki megalkotta a migráció törvényeit. Ezek értelmében a társadalmak közötti, térbeli egyenlőtlenség váltja ki a migrációt; ezért egyensúlyi elméleteknek is nevezik őket (Hárs 1992a; de Haas 2011). 


\subsubsection{A neoklasszikus közgazdaságtan makro- és mikroszintü elméletei}

Középpontjukban a különböző országok eltérő szintủ gazdasági fejlettsége, az ebből következő bérkülönbségek (makroszint), valamint az ezekre reagáló, önös érdekeiket követő, haszonmaximalizáló egyének (mikroszint) állnak (Massey 1999). Ezekből a modellekből kiindulva alakultak ki a húzó-taszító tényezők elméletei, amelyek nagyon népszerüvé váltak a migrációs kutatásokban, és a migrációról való diskurzusokban is elsődleges magyarázó tényezőkként jelennek meg, melyek értelmében a migrációt az egyén azon döntése motiválja, hogy saját gazdasági helyzetén javítson. A taszító tényezőket a származási ország hiányosságai képezik (pl. kedvezőtlen gazdasági és társadalmi feltételek), míg a húzóerőt a fejlettebb célországokban a várt és ténylegesen elérhető nyereségek jelentik, vagy a konkrét toborzás formájában ragadható meg (Portes 1995; Messina \& Lahav 2006).

A közgazdaságtani elméleteket számos kritika érte, föként azért, mert a migrációt nem folyamatként, hanem egy statikus jelenségként, másfelöl az egyént a külső körülményei által meghatározott alanyként kezeli (Portes \& Böröcz 1989; Guilmoto \& Sandron 2001). Mindebből látható a modell korlátozottsága: hiányzik a migráció és a migrációhoz vezető kezdeti feltételek közötti összefüggések meghatározása; egy post hoc magyarázatot nyújt a migráció okaira. Mivel mellőzi az egyéni tevékenység (agency) és bizonyos szinten a struktúra fogalmát, az egyént egy passzív alanyként kezeli, amely képtelen a független és önálló döntésekre, amik megváltoztathatnák a strukturális feltételeket; és ily módon ki van szolgáltatva a push-pull erőknek (de Haas 2011). Korlátaiból adódóan ez az elmélet nagyon sok kérdésre és jelenségre nem képes magyarázattal szolgálni, mint pl. a bérkülönbségek megszünése után is fennmaradó migrációra, a különböző térségek között levő eltérésekre a migráció mértékét és irányát tekintve (makroszinten), illetve az ugyanabból az országból, régióból származó egyének közötti különbségekre a migrációs készséget illetően (Portes \& Böröcz 2001). A munkaerő-migrációra a kibocsátó országok elmaradottságának és szegénységének eredményeként tekint, amelyből az következik, hogy a szegényebb társadalmak leghátrányosabb helyzetben levő tagjai akarnak leginkább részt venni a munkaerő migrációban. Ez a feltételezés viszont nem látszik beigazolódni, hiszen nem rendelkeznek a szükséges erőforrásokkal (Geddes 2011; Mckenzie \& Rapoport 2006; Demuth 2000). Továbbá kritika érte amiatt is, hogy úgy kezeli a migrációs folyamatokat, mintha spontánul jelennének meg, a globális egyenlőtlenségi skálán kívül (Portes \& Böröcz 1989; Guilmoto \& Sandron 2001). 


\subsubsection{Az új közgazdaságtan munkaerö-migrációs elmélete}

A neoklasszikus modell hiányosságain javított azáltal, hogy felismerte: a migráció általában egy több személyes döntés eredményeként jön létre, egy adott család, háztartás vagy tágabb közösség azon igyekezetéből, hogy a helyi munkaerő-, biztosítási és tőkepiacok hiányosságaiból származó kockázatot csökkentse azáltal, hogy „több lábon áll" (Massey 1999; Roberts 1995). A nagy kockázat és információ hiány nem arra ösztönzi a háztartások tagjait, hogy megerősítsék stratégiáikat vagy egy bizonyos tevékenységre specializálódjanak, hanem inkább arra, hogy megosszák stratégiáikat: némely tagot külföldre küldjenek (Guilmoto \& Sandron 2001; Portes \& Böröcz 1989). Ez a fajta stratégia megerösödése elvezethet oda, hogy a migráció fennmaradhat két ország között a bérkülönbségek megszünését követően is. A migrációs folyamat kezdeti szakaszában a munkaadók toborzásos tevékenysége segít legyőzni a migráns előtt felmerülő információs akadályokat, így a migráció értéke a családi jövedelemforrások és a kockázat megosztásban jelenik meg (Massey et al. 1994). Ez a modell ugyan nem tagadja a családok és közösségek jövedelemnövelő tevékenységét, viszont rámutat arra, hogy a kibocsátó társadalom tagjai között fennálló és növekvő jövedelmi különbségek és az ebből származó relatív depriváció is válthat ki migrációt (Massey 1999; Massey et al. 1993). Fő hiányossága abban áll, hogy a vándorlás folyamatát teljesen történelmi kontextusából kiragadva, attól függetlenül vizsgálja és elmulasztja konceptualizálni, hogy a makro-strukturális tényezők - mint az állam, munkaerö-piacok, politikák vagy kialakult társadalmi csoportok - milyen erősen korlátozzák az egyén és a család választási lehetőségeit, és nem képes megmagyarázni azt a jelenséget, hogy a legtöbb migrációs áramlat miért jelenik meg földrajzilag és társadalmilag szelektíven mintázott formában.

\subsection{Világrendszer és globalizációs elméletek}

A globalizációból eredő társadalmi, gazdasági és politikai átalakulási folyamatok a jelenkori migráció megértésének elengedhetetlen kontextusát képezik. A globalizációt alkotó áramlatok és hálózatok különbözö térségi szinteken - az országok fölött átívelö, nemzeti és helyi szinten - sajátos formákat öltenek. Ezek a hálózatok olyan komplex és dinamikus kapcsolatok részeiként müködnek, amelyekben a globális gazdasági és társadalmi erők módosítják a strukturális és kulturális tényezők szintjén, illetve a más szinteken adott válaszokat (Salt 2001). Az eltérö történelmi tapasztalatok, kulturális értékek, vallásos hitek, intézmények és társadalmi struktúrák egyaránt közvetítik és alakítják a külső erők hatásait, a változás vagy ellenállás különböző formáihoz vezetve, 
és egyben nagyon eltérő végeredményeket hozva az egyes közösségekben vagy társadalmakban (Castles 2012; Sassen 2007). Mivel tehát a globalizáció többdimenziós folyamat, a migrációhoz való kapcsolata is összetett: míg a globalizáció irányítja a migrációt és változtatja annak formáit, közben a migráció is - a globalizáció belső elemeként - fontos szerepet tölt be a közösségek és társadalmak átalakításában (Castles \& Miller 2009).

\subsubsection{A világrendszer elmélet}

A tömeges migrációs áramlatok okát a globális kapitalizmus terjeszkedésének közvetlen makro- és mikro hatásában látja. Feltételezése szerint a nagyfokú elvándorlást a kapitalista gazdasági viszonyok behatolása váltja ki a periférikus, nem kapitalista társadalmakba. Ezáltal a kapitalista rendszeren kívül keletkező munkaerő a migráción keresztül „,bekebelezhetővé válik”, és a migráns munkaerő lesz az összekötő kapocs a térben elkülönült kapitalista és nem-kapitalista termelési módok között (Prónai 2003).

Portes és Böröcz történelmi-strukturalista megközelítésében a spontán munkaerő áramlások a vándorlási folyamatoknak egy kései - a jelenkori - szakaszára jellemző, amelyben a munkaerő-migráció ezen folyamatoknak egyik fontos hajtóerejévé vált (Portes \& Böröcz 2001). Vagy a másik oldalról közelítve: a munkaerő kereslet nagy vonzerővel bír a migrációra (Hárs 2010). ${ }^{7}$ A szerzőpáros kiemeli, hogy a munkaerő spontán áramlásának időszakát megelőzi valamilyen múltbeli kapcsolat a kibocsátó és befogadó ország között (pl. gyarmatosítás vagy munkaerő toborzás). Ennek során a küldő állam struktúráiba behatoló - a későbbi fogadó - ország intézményei átalakítják a politikai és gazdasági rendszert, új - ez utóbbi országra jellemző - kulturális mintákat teremtenek, amelyre válaszként a migráció mint reális stratégia jelenik meg a kibocsátó társadalom tagjai számára (Portes \& Böröcz 2001; Sassen 2007). Tehát adott országok között zajló migrációs áramlatok leírásának, illetve az államok vagy térségek kibocsátó vagy befogadó szerepének magyarázatában egy kulcstényező az érintett országoknak a világgazdaságban elfoglalt relatív pozíciója (Melegh 2012). Ebböl következik, hogy globális szinten a vándorlás ellenőrzés alá vonása segít fenntartani az országok között létező hierarchiákat, valamint a gazdagok és szegények közötti egyenlőtlenséget (Melegh 2004; Castles 2000; Castles 2004).

A világrendszer elmélet hiányossága a nagyon deduktív és determinisztikus szemlélet, továbbá a csupán egyszeri változás elemzése, amely az egyént - a

\footnotetext{
${ }^{7}$ Ez utóbbi megállapítás elsősorban Magyarországra vonatkoztatva született, de általánosítható a fejlődő országokból a fejlett országokba történő vándorlásra. Hiszen, amint Castles is állítja, a gazdasági dimenzió minden nemzetközi vándorlásban jelen van (Castles \& Miller 2009).
} 
neoklasszikus modellhez hasonlóan - a gazdasági erők passzív alanyaként vagy éppen áldozataként kezeli (de Haas 2011; Melegh 2012). Másfelől viszont az elmélet erénye, hogy kidomborítja a strukturális feltételek befolyásoló szerepét, amelyek keretei között a tömeges migrációs áramlások végbemennek. Mert bár az egyéni döntés nem hagyható figyelmen kívül, számításba kell venni a kontextuális tényezők korlátozó szerepét is (Portes \& Böröcz 2001; de Haas 2011), amelyek adott társadalmi csoportok és földrajzi utak mentén mintegy terelgetik a migrációt. ${ }^{8}$

\subsubsection{A duális munkaeröpiac elmélete}

Értelmezésében a nemzetközi migráció a modern ipari társadalmak belső munkaerőkeresletéből fakad, és inkább a fejlett országok húzóerőire, mint a küldő országok tolóerőire helyezi a hangsúlyt magyarázatában. A fejlett országokban a munkabér nem csupán kereslet-kínálat, hanem státus és presztízs kérdése is (Massey 1999). A munkamegosztási hierarchia alján jelentkező munkaerőhiány csökkentésére a bérek növelése strukturális bérinflációhoz vezetne, amely nagyon költséges megoldást jelentene. Mivel a hierarchia alján levő munkások számára az alacsony bérek és a felfele való mobilitás kis lehetősége nem motiváló, olyan emberekre van szükség, akik a munkavégzést nem kapcsolják össze a munkával járó státussal, vagy legalábbis nem tulajdonítanak nagy jelentőséget neki. Ezt az olcsó megoldást a külföldi munkaerőben (vendégmunkás) találják meg, aki számára a munka mindössze pénzszerzési lehetőség, mely révén a kibocsátó társadalomban elfoglalt státusán igyekszik javítani (Horváth 2003a; Massey 1999). A külföldi munkavállalókat kezdetben többnyire a munkaerőintenzív másodlagos szektorban alkalmazták (vendégmunka toborzás), ahonnan a képzetlen munkások bármikor elbocsáthatóak voltak (Massey et al. 1993). Ez az elmélet megmagyarázatot nyújt az alacsonyan képzett munkaerő állandó migrációjára a fejlett országokba, még az ott növekvő munkanélküliség időszakaiban is. A munkamegosztási létra alján elhelyezkedők iránti igény szektor-specifikus és szerkezetileg a munkaerőpiaci struktúrába és a társadalmi-kulturális hierarchiákba ágyazódott. Ugyanakkor betekintést nyújt a jelenség komplexitásába: egy látszólag pusztán gazdasági jelenség hátterében mélyen gyökerező társadalmi-kulturális okok is meghúzódnak (de Haas 2011).

Habár a migrációs kutatások zöme a szakmailag kevésbé képzettek migrációjára fókuszált, a globalizáció következtében megjelenő multinacionális vállalatok és az ezeken a vállalatokon belüli, de országhatárokat átlépő mozgások gyakorivá válásával;

\footnotetext{
${ }^{8}$ Zolberg szerint a migráció iránya sokkal inkább a különböző korlátozásoktól függ, mintsem az ösztönző tényezőktől (idézi Hárs: (Hárs 1992a), illetve (Zolberg 2001)). Lásd továbbá: (Portes 1995).
} 
és ezzel párhuzamosan, a kommunikációs és utazási technológiák ugrásszerü fejlődése következtében kialakult transznacionális létforma elterjedésével, megfogalmazódott az igény ennek a - magasabb státusúnak tartott - társadalmi rétegnek a vizsgálatára is (Favell et al. 2008; Melegh 2011). Ebbe a második típusba illik bele az egészségügyi dolgozók csoportja is.

Vita tárgyát képezi a fejlődés és a nemzetközi migráció kapcsolata, egymásra gyakorolt hatása. Mivel a fejlődés és a globalizáció egy szállítási és kommunikációs infrastruktúra kiépítésével járt együtt, a munkaerő áramlása a javak és tőke áramlását követi, csak éppen fordított irányban (Massey et al. 1993; Melegh 2004; Sassen 2006).

Egyes kutatók szerint a migráció elősegíti az alacsony jövedelmű országok gazdasági fejlődését a hazautalt pénzösszegek révén. Ám nem bizonyított, hogy a hazautalásoknak csakugyan szegénységet csökkentő hatásuk van vagy inkább az egyenlötlenséget növelik (Castles 2000). A magasan képzettek tömeges elvándorlásával az ország elveszíti „értelmiségi tőkéjét” és az oktatásba fektetett beruházásának megtérülését (Greco 2010), ami gátolja a fejlődést. Castles szerint a két tényező között fennálló oksági viszony összetett: a migráció egyszerre következménye és oka is a fejlődésnek. Inkább a politikai reformok, a demográfiai és társadalmi változások vezetnek fejlődéshez, és nem a migráció (Castles \& Miller 2009). De Haas megközelítésében a nemzetközi vándorlás inkább a lehetőségek és a fejlődés relatív szintjéhez köthető, mint az abszolúthoz (Melegh 2012). A szakképzettek - akik rendelkeznek a szükséges erőforrásokkal és választási lehetőségekkel - többnyire mobilak; elvándorlásuk inkább a fejlődés kudarcára utaló jelzés, mintsem fő oka annak (Castles et al. 2014). A fejlődő országok esetében kialakulhat a migrációtól való strukturális függőség - a már említett hazautalt pénzösszegek révén -, és ilyenkor a migráció a fejlődést helyettesítő tényezővé válhat (Castles 2004). A migráció és a globális egyenlőtlenség közötti kapcsolatot kutatva megállapították, hogy a két tényező között egy nem-lineáris, inkább fordított $U$ alakú kapcsolat van: a fejlődés beindulása átmentileg még növelheti a migrációt, amely még fokozza az egyenlőtlenséget a kibocsátó társadalomban (Melegh 2012), de hosszú távon - a migráns hálózatok fejlődésével - egy erős egyenlősítő hatást fejt ki (Mckenzie \& Rapoport 2006).

\subsubsection{A transznacionalizmus}

A transznacionális elméletek a migrációs irodalom egy újabb irányzatát képviselik. Kiindulópontjában a szuverén nemzetállamok hanyatlásának gondolata, illetve az információs és szállítási technológiák ugrásszerü fejlődése következtében az utazási 
költségek csökkenésével a térbeli mozgás tömegessé és gyakoribbá válásának gondolata áll (Vertovec 1999; Levitt \& de la Dehesa 2003; Portes et al. 1999). A transznacionális migráció egy olyan társadalmi folyamat, amelyben a migráns egy földrajzi, politikai és kulturális határok feletti társadalmi mezőt hoz létre. Mivel társadalmi kapcsolathálója, tevékenységei és életmódja a kibocsátó és a befogadó társadalomhoz is köti őt, Schiller és munkatársai a „transzmigráns” kategóriát javasolták megnevezésére (Prónai 2003).

A transznacionális megközelítés szakít a korábbi elméleteknek a nemzetállamoknak „nemzeti tartálytársadalmakként” való felfogásával, amely feltételezte az állam területi szuverenitását, társadalmi, politikai-kulturális homogenitását, a sokszínű együttélést, és az érdekközvetítés révén történő problémamegoldást. A transzmigráció nem egy átmeneti időre szól, hanem egy új életformát jelent. A migráns beépülése egy nyitott végü folyamat, ami a végeredményt és a további fejlődést illeti (Pries 2003). A transznacionális perspektívából nézve a migránsok többé nem gyökértelenek, mivel szabadon közlekednek oda-vissza a nemzetközi határokon keresztül, különböző kultúrák és társadalmi rendszerek között (Brettel 2000).

A transznacionális közösségek kialakulására többféle magyarázatot nyújt a szakirodalom. $^{9}$ Egyes kutatók megkülönböztetik a kényszermigrációval, illetve a gazdasági okokból szétszóródott csoportok transznacionálissá válását (Vertovec 1999). Portes szerint ha a migráció tömeges és politikai okú, a migránsok inkább morálisan kötődnek a hátrahagyott rokonsághoz és közösséghez, és kezdenek olyan tevékenységekbe, amelyekkel áthidalhatják ezt a szakadékot (Sandu 2000b). Ellenben ahol a migráció individualizált folyamat, tehát egyéni és családi döntésen alapszik, a transznacionális tevékenységek kivételesek és szelektívek, nélkülözik azt a normatív összetevőt, amely egymáshoz kapcsolja őket. Ez esetben a transznacionális közösségek alapjának a megosztott információk, a kapcsolatok és bizalom együttesét tartja a kutató (Portes 1996). A transznacionalizmus három típusát különbözteti meg: a gazdasági, a politikai és a kulturális transznacionalizmust (Portes et al. 1999).

\subsubsection{Etnikai diaszpórák}

A transznacionális migrációs elmélet egyik paradigmáját az etnikai diaszpórák képezik. E szemlélet értelmében létezik egy közös tudat vagy a tapasztalatok sokasága, ami sok embert összeköt egy társadalmi képződménybe vagy hálózatba. Némely kutató szerint a diaszpóra-tudat „törött emlékei” a közösség és a saját történelem sokféleségét

\footnotetext{
${ }^{9}$ Bryan Roberts és munkatársai a mexikói transznacionális közösségeket vizsgálva egy hipotézist fogalmaztak meg, amely szerint a transznacionális migrációs minta akkor jelenik meg, amikor a kibocsátó közösség visszahúzó hatása és a befogadó gazdaság visszatartó ereje is erős (Portes et al. 1999; Roberts 1995).
} 
eredményezi: a szilárdság egy elutasítását, amely gyakran a helyi vagy a globális elnyomó helyzetekben való ellenállás forrásaként szolgál (Vertovec 1999). Ily módon a migránsok körében zajló transznacionalizálódás egyaránt felfogható az ellenállás egy módozataként vagy a globális kapitalizmusba való bekapcsolódásként (Vertovec 2001). Ha a transzmigránsok keresik is a rendszerbe való betagolódás lehetőségét, oly módon teszik azt, ahogyan számukra a legkedvezőbb (Kivisto 2001). ${ }^{10}$

Ennek az irányzatnak a központi gondolata, hogy a régi, szétszórt diaszpórák napjainkra transznacionális közösségekké alakultak át, melyeket a társadalmi szervezetek, a mobilitás és kommunikáció különböző módjai tartanak fenn (Vertovec 1999). Vertovec megállapítja, hogy a transznacionalizmus nem választható el az identitás fogalmától, mivel sok ember transznacionális cserehálózata és ezekben való részvétele a közös identitás felfogására épül, amely gyakran a származási hely és annak kulturális, nyelvi jellemzőin alapul (Vertovec 2001). Faist megközelítésében a diaszpórák csakugyan a transznacionális közösség egy sajátos típusát jelenítik meg, de csak abban az esetben nevezhetők transznacionálisnak, ha tagjaik jelentős társadalmi és szimbolikus kapcsolatokat építettek ki a befogadó társadalom felé. ${ }^{11}$

A többi elmélethez hasonlóan a transznacionalizmusnak is megvannak a maga korlátai, hiányosságai. Már maga a fogalom használata körül hiányzik az egyetértés, mivel a szakértők különbözőképpen konceptualizálták, és ebböl adódóan a fogalom elméleti többértelműséghez és elemzési zavarokhoz vezetett (Castles \& Miller 2009). Egyes szerzők szerint kevés migráns van, aki a transznacionális kategóriába beleillik, mivel idővel a nyitott végü, mindkét társadalomban szerepet játszó egyének előbb-utóbb letelepednek az egyik helyen, inkább otthonuknak érezve és tartva azt: asszimilálódva a befogadó társadalomba. Tehát a transznacionális migránsok leszármazottai között, azaz a másod- vagy többed generációnál már csak elvétve létezik transznacionális migráns (Castles \& Miller 2009; Kivisto 2001; Roberts 1995). Más szakértők viszont amellett érvelnek, hogy a „lebegő” - a transznacionális térben folyamatosan mozgó - életmód akár generációkon át fenntartható (Portes et al. 1999).

\footnotetext{
${ }^{10}$ Bauböck szerint a migránsok a gazdasági lehetőségeket, a biztonságos lakhelyet és kultúrájuk szabad gyakorlási lehetőségét keresik (Bauböck 2001).

${ }^{11} \mathrm{~A}$ transznacionális tér három típusát különbözteti meg, amelyekben eltérő a domináns integrációs mechanizmus. A szimbolikus kapcsolatoknak, amelyek lehetővé teszik, hogy az egyének hálózatokban, csoportokban és szervezetekben együttmüködjenek, három fajta forrása van: a kölcsönös kötelezettségek és elvárások- sajátos társadalmi kapcsolatokhoz kötődnek és a múltban nyújtott cseréken és szolgáltatásokon alapulnak-, a reciprocitás társadalmi normája és a hasonló helyzetben levők csoportján belüli szolidaritás. Ez a szolidaritás intézményesülhet pl. az állampolgárságban. Állandó vita tárgyát képezi, hogy kinek adható állampolgárság és milyen alapon (Faist 2000; Fakhri et al. 2003).
} 
Az elméletekhez kapcsolódó további kritikák a jelenség újszerüségét kérdőjelezik meg, mivel álláspontjuk szerint transznacionális közösségek léteztek amióta a bevándorló enklávé közösségek megalakultak a gyarmatosító anyaország városaiban, és amióta nagy tömegben vándoroltak Európából a tengerentúlra, még ha akkor nem is ezzel a megnevezéssel illették őket. Szokványos volt a visszatérés, és a kibocsátó közösség értékeinek megtartása volt inkább a szabály, mint kivétel. A transznacionális elmélet használhatósága ellen felhozott további érv, hogy nem fektet kellő hangsúlyt a belépési folyamatokra, márpedig a nemzetközi mobilitást a befogadó ország intézményi folyamatai funkcionálisan korlátozzák, módosítják. A nemzetközi körforgásban élő egyének számára az intézményes/törvényes korlátok és lehetőségek fontos befolyásoló tényezők a migráció formáját, tervezett időtartamát tekintve (Hárs 1992a; Conway 2000; Roberts 1995).

Mindezeken a vitákon túlmenően Melegh megközelítése tünik a leginkább kézenfekvőnek, aki a transznacionalizmust összekapcsolja a „migrációs ipar” kialakulásával. Ez az üzlet különböző szinteken és sokféle intézmény részvételével szervezi az emberek nemzetközi mozgását. Sokszereplős intézmény ő maga is, amely a küldő és a befogadó államokon és kormányzati szerveken túl magában foglal nemzetközi vállalatokat, munkaerő-közvetítő ügynökségeket, diaszporikus etnikai közösségeket, nemzetközi migrációs szervezeteket és embercsempészettel foglalkozó hálózatokat, akik egyszerre lehetnek a migránsok segítői és kihasználói. Ezek különböző - és esetenként egymással ellentétes - érdekeiket követve nyomást gyakorolnak, illetve befolyásolni igyekeznek a nemzetközi vándorlást. Ha érdekeik nagy mértéküek és azok ellentétesek a nemzeti migrációs politikákkal, akkor tevékenységükkel aláássák a kormány ellenőrzési kísérleteit (Melegh 2011; Castles \& Miller 2009).

Jelen értekezés alapjául szolgáló kutatás első generációs és potenciális migránsokat érint, akiknek egy része már egy kiszélesedett nemzetközi térben migrált vagy tervez vándorolni, amelyben az egyén szabad mozgása többé-kevésbé biztosított, és a határátlépéssel járó adminisztrációs követelmények is leegyszerüsödtek az Európai Unió tagállamai között (Recchi 2008). Ezek mind elősegíthetik egy transznacionális létforma kialakulását és fenntartását. Nem szabad ugyanakkor figyelmen kívül hagyni a jelenség sajátosságát az erdélyi magyarok esetében, amikor is egy eleve kvázi vagy „modern” diaszpórában élő magyar társadalom tagjai úgymond visszavándorolnak az anyaországba (Feischmidt \& Zakariás 2010; Sik 2011c).

Amint az eddig leírtakból következik - föként a transznacionalizmus kialakulási feltételeinek taglalásából -, a transznacionalizmus a globalizáció egyik terméke (Castles 
\& Miller 2009; Melegh 2011). ${ }^{12}$ A disszertációban csakis ilyen megközelítésben tekintek a transznacionális migrációra, vagyis a modern, globalizált világ kísérőjelenségeként. A migrációs szándék megszületését, illetve a külföldi munkavállalás tervezését elősegítheti a határok átjárhatóságára építő transznacionális szemléletmód.

\subsection{A migrációs folyamatok fennmaradásának elméletei}

A migrációs irodalom különböző visszacsatolási mechanizmusokat tárt fel, amelyek magyarázatul szolgálnak arra, hogy a migráció, ha egyszer kezdetét veszi, miért válik önfenntartó folyamattá, adott migráns hálózatok és migrációs rendszerek kialakulását eredményezve. Ezek a visszaható mechanizmusok nagyon jól szemléltetik az egyéni döntések és a struktúra kölcsönhatását, amelyben az egyének döntést hoznak és mozognak (Massey 1999; de Haas 2011).

\subsubsection{Migráns hálózatok és intézmények elméletei}

Ezek a hálózatok nagyon dinamikusak, mivel minden egyes migráns egyre inkább kiterjeszti a hálózatot, és csökkenti a földrajzi mobilitás kockázatát mindazok számára, akikkel kapcsolatban áll, növelve ezáltal a további migráció valószínüségét (Massey et al. 1993; Hárs 1992a). Tehát a migráns hálózatok és migrációs rendszerek a tömeges migráció fennmaradását eredményezik, a vándorlást kiváltó okok megszünése után is. A szakértők körében nincs egyetértés a tekintetben, hogy ezek a hálózatok mint mezoszintű rendszerek milyen mértékben határozzák meg az egyéni cselekvést. Wilson szerint a hálózat-közvetítésű migrációs lánc nem feltétlenül jelenti azt, hogy a jövendőbeli migráns vagy annak családja számára csak egy vagy néhány célterület nyitott, ahová mehetnek. A migráns hálózatokat úgy kell felfogni, mint elősegítő és nem tokba záró, mint átható, kiterjedő és képlékeny, és nem mint merev és kötött struktúrákat (Brettel 2000). Viszont Guilmoto és Sandron azt hangsúlyozza, hogy azáltal, hogy a migráns hálózatok az első migráns csoportok vándorlására épülnek és azon képességükre, hogy egy bizonyos célországot és szakmai szektort céloznak meg, a már kialakult network-ök becsatornázzák vagy korlátozzák a későbbi migránsok körforgását (Guilmoto \& Sandron 2001).

Abból a szempontból viszont egységes az álláspont, hogy a migráns hálózatok társadalmi tőke gyanánt müködnek az egyén és a csoport számára: a tagok hozzáférnek a hálózatban levő más tagok társadalmi tőkéjéhez. Ennek a tőkefajtának az alapvető

\footnotetext{
${ }^{12}$ Portes transznacionalizmusról való definícióját véve alapul, amelyben a transznacionalizmus korábbi és a modern kori formája közötti különbséget taglalja (Portes et al. 1999).
} 
tulajdonsága a konvertabilitás: átváltható más fajta tőkére (Massey 1999; Portes 1995). Nem egységes viszont a fogalom konceptualizálása a különböző társadalomtudósok esetében, megalkotása óta különböző értelmezési változásokon ment keresztül. ${ }^{13}$ Portes meghatározását követve az egyén azon képességét értem társadalmi tőke alatt, hogy társadalmi kapcsolatai révén bizonyos erőforrásokhoz juthat hozzá, vagyis egy adott társadalmi struktúrában való tagságának köszönhetően igényelheti a társai által birtokolt forrásokat (Portes 1998). A család és a közösség szerepe lényeges a migráns hálózatokban. A családi kapcsolatok biztosítják gyakran mindazt a pénzügyi, kulturális, és társadalmi tőkét, amelyek lehetségessé, megvalósíthatóvá teszik a migrációt (Castles \& Miller 2009; Tilly 2001). A nagy távolságokon átívelő kapcsolatok, a családi és baráti kötelékek, az ezeken keresztül áramló új információk és az általuk kiváltott érdeklődés legalább annyira fontossá váltak a visszatérő migrációs mintában, mint a gazdasági nyereség fenntartása (Portes \& Böröcz 1989). Tehát a migráns hálózatok szolgálnak az elsődleges magyarázatul arra, hogy az országok miért találják nehéznek ellenőrzésük alatt tartani a már egyszer beindult migrációs folyamatokat (de Haas 2011).

A migráns hálózatok elméletei sokáig csak a társadalmi tőke pozitív hatásait szemlélték, és figyelmen kívül hagyták ezeknek a hálózatoknak az erősen korlátozó, visszahúzó szerepét, ugyanis a migránsok visszaélhetnek a csoporttagsággal járó kötelezettségekkel, illetve nem feltétlenül segítik egymást. Úgy tünik, hogy a hálózatok pozitív hatásai az idő előrehaladtával csökkennek (Portes 1995; Portes \& Sensenbrenner 2001; de Haas 2011).

A migrációs irodalomban a kapcsolati tőke a társadalmi tőke egy konceptualizálásaként jelenik meg. Kutatások sora foglalkozott az egyén kapcsolati tőkéje - amely magában foglalja, hogy kikkel áll kapcsolatban, milyen típusú ez a kapcsolat, mennyire intenzív a kapcsolattartás - és a migrációs szándék közötti összefüggésekkel (Sik 2003; Sik \& Örkény 2003; Massey et al. 1994). Gödri tovább árnyalta a kapcsolati tőke és a vándorlás közötti kapcsolatot, rámutatva arra, hogy az egyén migráns kapcsolathálója befolyásolja a migrációs döntést, elősegítve a cselekvést (a migrációs terv megvalósítását), még akkor is, ha ezek a kapcsolatok a későbbiekben nem mobilizálódnak (Gödri 2010). ${ }^{14}$

\subsubsection{Kumulált okság}

Massey szerint a vándorlás hátterében meghúzódó okok kumulatívak, abban az értelemben, hogy a vándorlási térben történő minden egyes mozgás módosítja azt a

\footnotetext{
${ }^{13}$ Ennek részletes taglalását lásd Orbánnál (Orbán 2006) illetve Portes-nél (Portes 1998).

${ }^{14}$ Kutatási eredményei alapján a célország társadalmába való beilleszkedésben viszont csak a ténylegesen mobilizált kapcsolatoknak van szerepe.
} 
társadalmi környezetet, amelyben a további migrációs döntések megszületnek, általában növelve a későbbi mozgások valószínűségét (Massey 1999: 45). Ide sorolhatók a korábban már említett migráns hálózatok terjedése, a relatív depriváció, a migrációhoz kapcsolódó értékek és a vándorlás kulturális megítélése. Massey és munkatársai a migrációs kultúra kialakulása kapcsán inkább az egyéni oldalon bekövetkezett változásokat emelik ki: az ismétlődő térbeli mozgás relatív állandó változásokat vált ki az egyén motivációiban, a társadalmi struktúrában elfoglalt helyében, kulturális miliőjében, amelyek együttesen módosítják ezt a döntési környezetet (Massey et al. 1994).

De Haas bírálta a migráns hálózatok elméletét a tekintetben, hogy figyelmen kívül hagy más visszajelző mechanizmusokat, amelyek a migrációnak a kibocsátó és befogadó környezetre való hatásán keresztül müködnek. Szerinte a kibocsátó társadalomban a migráció hatására kialakult jövedelmi egyenlőtlenségek vagy relatív depriváció, illetve a célterületen megvalósuló etnikai alapú munkaerő-piaci szegmentálódás mind példák ezekre a visszacsatolási mechanizmusokra. Felhívja a figyelmet, hogy egy kölcsönös egymásra hatásról van szó: a migráció megváltoztatja a kezdeti szerkezeti feltételeket, amelyek közepette a vándorlás elindult, és cserében ezek a strukturális feltételek is befolyásolják az egyéni aspirációkat és lehetőségeket (Guilmoto \& Sandron 2001; de Haas 2011). Brettel megfogalmazásában a migránsok változást hoznak a helyi közösségekbe nemcsak a pénzügyi, hanem a társadalmi átutalások révén is; miközben alakítják a politikai, gazdasági, társadalmi és kulturális környezetüket - akár a küldő, akár a befogadó társadalomban -, ugyanakkor ők maguk is formálódnak mindezek hatására (Brettel 2000).

A migráció kezdetben egy szelektív folyamat, és elsősorban a képzettebb, motiváltabb, kedvezőbb anyagi helyzettel rendelkező egyének számára lehetséges a vándorlás. A mozgás és a migráns hálózatok kiterjedésével ez a szelektivitás és egyben a mozgással járó kockázatok és költségek is csökkennek, míg végül a migrációs áramlatok függetlenné válnak az őket kiváltó okoktól és önfenntartók lesznek. Ez hosszú távon a küldő térségek humán tőkéjének kimerüléséhez vezethet, amely viszont még inkább megerősíti a vándorlásra ösztönző feltételeket (Massey 1999).

Összefoglalóan az alábbi elméleteket tartom fontosnak a kutatás során: a történelmistrukturalista megközelítést; a globalizációs szemléletmódot (országok relatív pozíciója); a mezo-struktúráknak a migráns hálózat és kumulált okság elméleteit; a neoklasszikus közgazdaságtan által megalapozott húzó-taszító tényezők modelljeit és a duális munkaerőpiac elméletéből a társadalmi státus szerepét. 


\section{DIPLOMÁS VÁNDORLÁS: EGÉSZSÉGÜGYI DOLGOZÓK MIGRÁCIÓJA}

Különös horderővel bír a nemzetközi migráció kérdéskörében a magasan képzett munkaerő, így az egészségügyi dolgozók tömeges migrációja. Ez utóbbi csoport vándorlásának egyedi jelentősége abban áll más foglalkozási csoportokhoz képest, hogy nemcsak a lakosság egészségi állapotára hat ki, hanem közvetve befolyásolja annak gazdasági teljesítőképességét és életminőségét is (Eke et al. 2009; Greco 2010). Az egészségügyi szakemberek migrációjának egy másik sajátossága az - állítja a szakirodalom egy másik szegmense -, hogy növekedése az elmúlt évtizedek során részben annak tulajdonítható, hogy a szakképzetlenek migrációjával ellentétben, a szakképzett munkaerő egy jelentős fokú szabályozatlanságot és liberalizációt tapasztalt, amely nagyon hasonlít a neoliberális globalizáció általános mintáira (Jakab 2011; Lavenex 2008; Castles \& Miller 2009). A vándorlási folyamatok és a mögöttük meghúzódó érdekek összetettségét jelzi, hogy a növekvő mértékü kivándorlás egyfelől nagyon költséges a beruházó- kibocsátó országok számára, tekintetbe véve a meg nem térülő képzési beruházások összegét; ráadásul szakember hiánnyal kell szembenézniük. Másfelől a toborzó- befogadó országok részére könnyen elérhető és gyors megoldást jelent a fennálló szakmunkaerő-hiány betöltésére a külföldi munkaerő vonzása. Ez a folyamat viszont nem tartható fenn, nem nyújt megoldást hosszú távon, mivel ez utóbbi tevékenység nemzetközi szintü etikai problémává vált a külföldi emberi erőforrások kimeríthetőségére hivatkozva. További érv fenntarthatósága ellen az, hogy a következő évtizedekben az egészségügyi dolgozók iránti igény növekedése várható a jóléti társadalmak öregedésének, a várható élettartam növekedésének, a nagyobb egészségtudatosság és közösségi elkötelezettségnek köszönhetően (Juss 2007).

$\mathrm{Az}$ egészségügyi dolgozók migrációja valamennyi európai és Európától távol eső országban megtalálható jelenség, és egyfajta „helyettesítő-migrációt” vált ki: az egyik országban fellépő hiányt más ország orvosaival igyekeznek pótolni. Becslések szerint az ezredfordulón 1,5 millió, a kevésbé fejlett országokból jövő, magasan képzett szakember dolgozott a fejlett országokban (Jenkins et al. 2010).

Viták folynak a munkaerő-mozgás liberalizálása kapcsán arról, hogy szabadabbá

vált-e a mozgás vagy sem. Az eddigi kutatások többnyire egységesként kezelték a munkaerő migráció különböző formáit. A transznacionális közösségeket leíró kutatások főként a menekültekre és alacsonyan képzett dolgozók migrációjára fókuszáltak, mivel elsősorban azt kívánták feltárni, hogy a kiváltságokat nélkülöző csoportokban az etnikai 
hálózatok és - kultúra hogyan segítik elő a gazdasági és politikai tevékenységet. ${ }^{15} \mathrm{~A}$ kutatásuk alanyát képező migráns sokkal valószínübb, hogy ellenőrzésnek és korlátozásnak van kitéve (Favell et al. 2008). Favell és munkatársai szerint a nemzetközi mozgás liberalizációjáról való teljes kép megalkotásához a másik oldal vizsgálata is szükséges. Ezért a nemzetközi térben mozgó szakembereket (professionals), a magasan képzett vagy technikai migránsok vándorlását kutatták, akiknek térbeli mozgása inkább a saját választáshoz, illetve a szakmai karrierhez és oktatási/képzési lehetőségekhez kötődik, mint az alacsonyan képzett munkaerőé. Az elemzők előzetes várakozásai szerint ez a csoport az, melynek tagjai a legkevésbé találkoznak a kirekesztés vagy gazdasági kizsákmányolás formáival, és ezért vándorlási tapasztalataikból kiderülhet nem csak az, hogy a liberalizáció milyen mértékben valósulhatna meg ideális feltételek mellett, hanem az is, hogy milyen korlátozások maradtak még fenn a mobilitás útjában. Véleményük szerint a transzmigráns szerepét a magasan képzett migránsok lennének képesek betölteni, mivel ők a globális gazdaság által kivételezettek: olyan nemzetállamok által toborzottak, amelyek készek bezárni határaikat a nemzetközi migráció sok más formája előtt. Továbbá olyan szintű humán és társadalmi tőkét birtokolnak, amely leginkább segítik őket egy globális élet valódi megteremtésében az új célterületen (Favell et al. 2008).

Egyes kutatók amellett érvelnek, hogy a magasan képzettek vagy szakemberek migrációja azért kapott mindeddig kevesebb figyelmet, mivel belépésük és alkalmazkodásuk a befogadó társadalomhoz ,zökkenőmentesen” történik, így jelenlétük is kevésbé feltünő illetve jelent problémát a fogadó ország számára (Portes 2008; Scott 2006; Sassen 1995). Ezt segíti elő a megkönnyített intézményi feltételek keretei között való belépésen kívül a szakemberek kulturális és humán tőkéje: többnyire beszélik az adott ország nyelvét, könnyen és rugalmasan alkalmazkodnak a kultúrához, illetve humán tőkéjük kedvező munkaerő-piaci lehetőségekre váltható át (Portes 2008) ${ }^{16}$. Vagyis a politikai fogadtatás módján túlmenően a származás is befolyásolja a beilleszkedés mintáját, a munkaerő-piaci sikerességet (Sassen 1995; Portes \& Böröcz 1989). Semleges politikai környezetben a befogadás sikeressége az egyéni érdemen és szaktudáson áll; a migráns szabadon versenyezhet a helyi munkaerő kínálattal, és lehetősége van arra, hogy a legmagasabb pozíciót érje el az elsődleges munkaerő-piaci szektorban, még akkor is, ha a rangléta alacsony fokán lépett be a rendszerbe (Portes \&

\footnotetext{
${ }^{15}$ Lásd pl. (Turner \& Bonacich 2001; Portes 1995; Wiegand 2001; Roberts 1995)

${ }^{16}$ Empirikus adatok viszont arra is rámutattak, hogy bár a szakemberek/magasan képzettek mobilitása és a befogadó társadalomba való integrációja a képzetlen migránsokétől jelentősen eltérő mintázatot mutathat, a kiváltságokkal való élés nem jelenti egyszersmind a globális mobilitással és az áttelepüléssel járó nehézségek kiküszöbölését (mint pl. alulfoglalkoztatás vagy „üvegplafon” jelenségének megtapasztalása) (Favell et al. 2008).
} 
Böröcz 1989). Legalábbis a humán tőke eme szállíthatóságába és általános érvényesíthetőségébe vetett egyéni hitben látják egyes kutatók a globális mobilitás „mítoszának” erejét, mely hit egy olyan feltételezéshez vezet, miszerint tulajdonosa bárhol, bármely országban boldogulhat, a társadalmi struktúrától és reprodukciótól függetlenül (Favell et al. 2008). A másik, a társadalmi struktúra oldaláról nézve a dolgot pedig: egy mesterségesen megalkotott szakértelem-osztály hierarchia könnyíti meg a közép- és felsőosztály nemzetközi mozgását a fejlett világban (Scott 2006). Castles ezt a megkülönböztető bánásmódot, amelyet a migránsok különböző csoportjaival szemben alkalmaznak, nevezi a transznacionális osztálystruktúra új típusú alapjának (Castles \& Miller 2009). Ö is hangsúlyozza, hogy a globális munkaerőpiac nem csak a humán tőke alapján, hanem faj, nem, származás, etnikum és törvényes státus szerint is rétegzett (Castles et al. 2014).

\subsection{Társadalmi státus és migráció}

A társadalmi osztály mint elemzési dimenzió háttérbe szorult az identitás-politika fogalmainak (etnikum, nemzetiség, faj, vallás) elterjedése következtében. Mivel a migráció az identitások összetett átalakulását és keveredését eredményezi, a politika színterén az identitással kapcsolatos kérdések dominálnak; ám nem téveszthető szem elöl, hogy az identitást az osztálydinamizmus formálja és táplálja a háttérből (Kearney 2004). Az osztályelemzés egyik dimenzióját az egyenlőtlenségeket és a kulturális identitások különböző fajtáit termelö mechanizmusok vizsgálata képezi (Savage 1995). A migrációs politikák szelekciós mechanizmusára utal az, hogy bizonyos identitással rendelkező egyének akadálytalanul átkelhetnek adott országhatárokon azon rend alapján, amely meghatározza és fenntartja ezeket a határokat; míg más identitással bírók nem. Önmagát reprodukáló folyamatról van szó: azok az egyének, akik nem ütköznek akadályba a határátlépéskor, valószínüleg előnyösen kapcsolódnak (associated) ahhoz a politikai rendhez, amely az érintett határt meghatározza (Kearney 2004).

Az osztályhelyzet vizsgálatának összetettségét jelzi - amint több kutatás eredménye is megerősítette -, hogy nagyon eltérő erőforrásokkal és életeséllyel rendelkező egyének ugyanazon „osztály” tagjaiként azonosították magukat (Portes 2008). A kutatók általában középosztályokról beszélnek, annak belső rétegzettsége miatt (Butler 1995). Goldthorpe a szolgáltatói osztálynak - amelynek a szakértői (professional) alkalmazottak is részét képezik - a középosztály más csoportjaitól való megkülönböztető jellegét munkájuk nagy fokú autonómiájában, illetve az alkalmazó bizalmának birtoklásában határozza meg (Goldthorpe 1982). Ez a bizalom a rájuk 
ruházott, általuk képviselt hatalmon és a rajtuk keresztül hordozott szaktudáson nyugszik. ${ }^{17}$ Mivel ezt a tudást bizonyítványaik révén képesek társadalmi és gazdasági státussá konvertálni, az oktatási rendszer szerepe kulcsfontosságú a középosztály számára (Butler 1995). Ebből kifolyólag a speciális tudáshoz való hozzáférést igyekeznek ellenőrzésük alatt tartani, amely a csoport társadalmi bezáródásához vezethet - az orvosi szakma területén ez pl. az osztály és a gender dimenziók mentén ment végbe (Witz 1995). Jóllehet napjainkban az orvosi szakma elnőiesedése figyelhető meg (George 2007; Rohova 2011). Ám úgy tünik, hogy az oktatás expanziójával az iskolai teljesítmény szerepét mindinkább visszaszorítja a származásé (Kolosi \& Keller 2012). Másodgenerációs bevándorlók körében végzett kutatás megállapítása szerint a leszármazottak nagyon gyakran a család nemzetközi vándorlását megelőző osztályhelyzetét reprodukálják, mivel a közép- és felső osztályból származó gyerekek olyan kulturális tőkével rendelkeznek, amelyeket egyfelől az iskola jutalmaz, másfelől a határon keresztül szállíthatók - a szüleik révén (Feliciano 2005).

Az oktatás nemzetközivé válásával ${ }^{18}$ már a munkaerőpiacra való kilépés előtt nagyfokú szelekció megy végbe, amely a tanulmányi migrációhoz köthető (Knight 2014; Hawthorne 2012). A nemzetközi mobilitás a középosztály identitásának újratermelésében egyre jelentősebb szerepet tölt be. ${ }^{19}$ Még ha nem is kötődik karrierúthoz, a migrációjuk alátámaszthatja a státus megkülönböztetést, mivel mobilitási tőkét képez (Scott 2006). Bourdieu megközelítésében az osztály és az életstílus összekapcsolódik az életkörülmények megteremtésében, amelyek a tőkejavak függvényében valósulnak meg, és habitust (hajlamokat, ízléseket) teremtenek. Kutatók tapasztalták „életstílus” migránsok vizsgálata során, hogy ezen egyének cselekvése nagyon kis mértékben tért el a társadalmi csoportjukra jellemző szokásos cselekvésektől; a habitus csak lassan változik (Oliver \& O’Reilly 2010). Ezeknek a migránsoknak a múltja látszólag irreleváns volt az új környezetben, de többségük mégis a korábbi osztályhelyzetét termelte újra habitusa, gazdasági és kulturális tőkéje megkülönböztető jellegével.

\footnotetext{
${ }^{17}$ Ez a paramedikus szakmákra kevésbé jellemző. Nem hagyható figyelmen kívül az a tény, hogy bár a nővérek helyzete a globális munkaerőpiacon hasonló az orvosokéhoz - mozgási szabadságukat, kedvező fogadtatásukat tekintve -, a munkamegosztás lokális szintjén hierarchikus viszonyban állnak egymással, amely meghatározza státusukat, tevékenységük autonómiáját, hatalmukat. A nővéri szakma presztízse jóval alacsonyabb az orvosinál az alárendelt helyzet, illetve a nök magas arányának következtében. A gyógyszerészek és fogorvosok kevésbé szorosan tagozódnak be a munkamegosztási hierarchiába, és munkájuk is kisebb mértékben ellenőrzött (Freidson 1970). Mivel a disszertáció a nemzetközi térben való mozgást taglalja, az egészségügyi dolgozókra többnyire egységes csoportként tekintek, figyelmen kívül hagyva a belső hierarchikus tagolódást.

${ }_{18}$ A bolognai rendszer kialakulásáról és működéséről bővebben lásd: (Huisman et al. 2012).

19 A szerző érvelése szerint a nemzetközi mobilitás révén szerzett tapasztalatok a növekvő középosztály rétegződését segítik elő, ahol a másodlagos- és harmadlagos oktatás szerinti választóvonalak mindinkább elveszítik hagyományos értelmüket (Scott 2006).
} 
Az egészségügyi dolgozók is a migrációs politikák egyik privilegizált csoportjához tartoznak. A fejlett országok jóléti társadalmának egészségügyi ellátások iránti igényének növekedése és határaik megnyitásával, továbbá az azzal járó kölcsönös diploma-elismerés eredményeképpen (Lavenex 2008) az erdélyi egészségügyi munkaerő egyre nagyobb arányban érintett a nemzetközi migrációban.

Természetesen a strukturális dimenzió és annak hatásai a szakértők vándorlása esetében sem hagyható figyelmen kívül. Amint Favell és munkatársai is megállapítják, a magasan szakképzettek migrációját is, éppúgy mint a makrogazdaság piaci logikájának erőit, intézményi korlátok és irányító mechanizmusok szabályozzák, mint pl. a különböző vállalati és szakmai korlátozó mechanizmusok, amelyek strukturálják azokat a lehetőségeket és korlátokat, melyekkel a képzett szakemberek szembetalálják magukat, akik a transznacionális migráció révén próbálják javítani életesélyeiket vagy megőrizni státushelyzetüket (Favell et al. 2008).

Világszintü egészségügyi-munkaerő válság kialakulását jelző folyamatok közepette ezek a vándorlási áramlatok a globális politika problémakörébe kerültek (Jenkins et al. 2010). Az egészségügyi szakemberek földrajzi mobilitása mellett és ellenében különböző érvek szólnak. A toborzó állam részére nyereséget jelent, mivel egyfelől ez a migráns csoport hozzájárul az ország humán tőkéjének növeléséhez, másfelől úgy részesül szakértelmében és szakmai tapasztalatában, hogy megspórolja az oktatási és bizonyos mértékben a képzési költségeket. A kibocsátó ország részére származó nyereség már kevésbé egyértelmü, de az általában felhozott érvek a következők: a hazautalt pénzösszegek és az azokból származó innovációs lehetőségek, a munkanélküliség csökkenése (ám ez utóbbi természetesen nem érvényes abban az esetben, ha az adott országban is már eleve hiányszakmáról vagy szakterületről van szó), illetve visszavándorlás esetén a hozott szakértelem és technológiai transzfer (Castles \& Miller 2009; Greco 2010). Hátrányként az agyelszívást - amely a származási országnak az oktatásba és szakképzésbe fektetett költségeinek meg nem térülését jelenti -, illetve a befogadó országokban a külső munkaerőtől való függőség kialakulásának veszélyét említik a kutatók (Lavenex 2008). További hátrányt jelenthet még a kibocsátó országok esetében, hogy a középosztály az a réteg, amely leginkább érintett, és fogy az elvándorlás következtében: ez egy fontos adófizetői csoport és - feltételezhetően gyermekei is termelékeny szakemberek lennének. Veszteségként könyvelhető el a „brain waste” jelensége is, amikor a fogadó országban a migránst nem képzettségi szintjének megfelelően, hanem az alatt foglalkoztatják (Greco 2010; Packer et al. 2010; 
Levitt \& de la Dehesa 2003). Viszont az elönyökként említett tényezőket illetően sincs egyetértés. A hazautalt pénzösszegek esetében is vita folyik arról, hogy tényleg a szegénységet csökkentik-e az alacsony jövedelmü országokban vagy az egyenlőtlenségeket növeli, illetve újratermeli. Továbbá a hazautalt pénzek tényleges nagyságáról, ${ }^{20}$ és a kibocsátó közösségekben való felhasználásuk módjáról nagyon kevés a tudományos ismeret (Greco 2010).

\subsection{A jelenség etikai vonzata}

Etikai téren különböző kérdések merülnek fel az egészségügyi dolgozók toborzása kapcsán, igazságosságának megkérdőjelezésétől (filozófiai értelemben vett jogosság alapján) kezdődően, a morális alapon orvvadászatnak vagy bűncselekménynek való minősítéséig. A fejlődő országokban tapasztalható súlyos szakemberhiány és a fejlett országokból érkező erős szívóhatás, mely a toborzásban nyilvánul meg, arra utal, hogy az egyenlőtlenség a gazdaságilag fejlett és fejlődő országok között tovább növekszik (Kaelin 2011; Cehan \& Teodorescu 2012). A toborzás etikusságát megkérdőjelező szakértők félelme elsősorban az alacsony- és közepes jövedelmű országok amúgy is törékeny egészségügyi rendszerének további gyengülésén, illetve az egészségügyi dolgozók elvesztése következtében a rendszer teljes összeomlásán alapszik (Jenkins et al. 2010; Jakab 2011). Válaszképpen 2010-ben az Egészségügyi Világszervezet (WHO) kiadta az Egészségügyi Személyzet Nemzetközi Toborzási Gyakorlatának Globális Törvénykönyvét. Ebben a szervezet elítéli a munkaerőhiánnyal küzdő országokból való aktív toborzást, és útmutatást nyújt a munkaerő és az egészségügyi rendszer megerősítésére: a személyzet visszatartására, a munkaerő fenntarthatóságára és a hatékony munkaerő tervezésére. Ezen célkitüzések megvalósítása érdekében szorgalmazza a képzés és az oktatás további fejlesztésének megerősítését és a munkaerö-piaci tevékenységek felügyeletét és koordinálását (Jakab 2011). Ám a szükséges erőforrások hiányában a kevésbé fejlett országoknak az egészségügyi személyzetük visszatartására irányuló erőfeszítéseik kimenetele kérdéses. Hiszen, amint arra Kaelin rámutat, az eddig történt hasonló próbálkozások - mint például a kibocsátó országokban a bérek növelése, vagy a befogadó országokban a toborzás beszüntetése nem voltak fenntarthatóak hosszú távon (Kaelin 2011). A kibocsátó országok tanintézeteiben a keretszámok növelése sem vezet önmagában eredményre, mivel csak

\footnotetext{
${ }^{20}$ A banki átutalások összegeit szokták alapul venni, de egyes becslések alapján a személyesen, nem pénzintézetek révén hazajuttatott pénzösszegek még egy legalább akkora mennyiséget tesznek ki (Black et al. 2006) pl:: (UN 2006). A Világbank becslése szerint Románia 2007-ben benne volt az első 10 legtöbb hazautalt pénzösszegben részesülö ország között (kb. évi 9 millió dollár). 2006-ban a GDP 5,5 százalékát tette ki, amivel az ország második legfontosabb pénzügyi forrásává vált (Rohova 2011).
} 
növekszik a potenciális migráns népesség és az adott ország oktatásba fektetett költsége, illetve az elvándorlás általi vesztesége. Egyes szakterületeken, ahol különösen nagy az agyelszívás, a helyben maradókra háruló többletmunka, növekvő stressz és szakmai elszigeteltség ugyancsak további növelheti a migrációt (Jenkins et al. 2010; Greco 2010).

Némely befogadó ország, mint az Egyesült Királyság - vélhetően a különböző nemzetközi szervezetek nyomására -, saját etikai kódexet fogalmazott meg, amelyben tiltja az aktív toborzást a nagyon hátrányos (gazdaságilag kevésbé fejlett és maga is súlyos egészségügyi munkaerő-hiánnyal küzdő) országokból. Egy kritikus, aki méltányolja ugyan ezt a gesztust, rámutat a nyitva hagyott kiskapukra, mint pl. arra, hogy a korlátozás nem vonatkozik a magánszférára, amelyben pedig a munkaerő vándorlásának többsége zajlik, illetve, hogy csak a csoportos toborzást tiltja, míg az egyéni toborzás tovább folytatódik (Sigler 2010).

Ellentét feszül az állampolgároknak az egészséghez való jogának és az egyének szabad mozgáshoz való emberi jogának biztosítása között (Shah 2010a). Az egészséghez való jogot tág fogalomként értelmezve az oktatáshoz való hozzáférés, az elvégzett munkáért járó méltányos fizetés és a pihenésre való idő is beleértendő amelyhez az egészségügyi dolgozóknak is éppúgy joguk van, mint bárki másnak; és hiányuk esetén dönthetnek a migráció mellett (Shah 2010b). Elvándorlásukkal viszont korlátozzák honfitársaik egészségügyi ellátáshoz való hozzájutását, azaz egészséghez való jogukat sértik. A témával foglalkozó szakértők némelyike az intézményes, politikai szinten való megoldás keresését sürgeti. Javaslataik között szakmai (magasabb szintü képzés, ösztöndíjak, folyamatos szakmai fejlődés, kutatási lehetőségek és rugalmas munkaidő biztosítása) és szociális ösztönzők (szolgálati lakás, gyerekfelügyelet, ingyenes étkeztetés, jobb felszerelés, biztonságos munkakörnyezet: védőoltásokhoz, gyógyszerekhez valóhozzáférés bizonyos betegségek megelőzésére) szerepelnek (Jenkins et al. 2010). Ám az általuk felsorolt tényezők többségének biztosításához gazdasági tőkére, nagyobb anyagi erőforrásra lenne szükség, és éppen ez az, amiben a kibocsátó országok szükölködnek. Ennek is tulajdonítható, hogy más kutatók mikroszinten, az egyénnél keresik a megoldást, és a migráció morális dimenzióját hangsúlyozva, az egészségügyi dolgozók társadalmi felelősségét állítják a középpontba. A szabad mozgáshoz és az egészséghez való jog közötti ellentmondásra a választ magánál az egyénnél vélik megtalálni, akinek saját magát kellene korlátoznia egyéni jogai gyakorlásában (értsd: a szabad mozgás jogával való élését), hogy mások jogait ne sértse (Cehan \& Teodorescu 2012).

Az Európai Unión belül nemcsak egyes tagállamok küzdenek az elvándorlásból 
fakadó súlyosbodó munkaerő-hiánnyal, hanem regionális szinten is nagy a hiány. A WHO becslései szerint 2020-ra az EU-ban 1 millió fős lesz a hiány az egészségügyi dolgozók körében. Ezen kihívás orvoslásához minden szereplő - a politikai vezetők, az egészségügyi szakértők és a civil társadalom - együttmüködésére van szükség. A szakember menedzselés-tervezés megvalósításában az egyik legnagyobb gondot az adatok hiánya okozza, amely miatt a feladat jóformán teljesíthetetlenné válik (Coggi 2011). Mégis vannak próbálkozások uniós szinten a migráció nagyságának felbecsülésére az egyes tagországokban a munkaerő-tervezése és menedzselése céljából (pl. a MoHProf program). Mindezek hosszú távon keresik a megoldást a szakember hiányra, amely rövid távon nem is orvosolható.

A kooperáció egy másik, globális szinten még súlyosabb akadálya az a korábban is említett érdekellentét, amely a kibocsátó és befogadó országok vagy másképpen a fejlett világ országai és a fejlődő államok között feszül. A kormányok közötti függőség aszimmetrikus, a küldő országok kevéssé tudják kontrollálni szakembereik elvándorlását, tehetetlenek a beindult migrációs áramlatokkal szemben. Erre ráerősít a másik oldalról a fogadó országok részéről kifejtett szívóhatás, akik - a képzetlenek migrációjával ellentétben - kedvezően fogadják a szakemberek bevándorlását, sőt, a korlátozott munkaerő kínálat miatt egymással versenyeznek, hogy magukhoz vonzzák őket. Ezek együttesen gátolják az együttműködési mechanizmusok létrejöttét maguk a célországok, illetve a célországok és küldő országok között (Levatino \& Pecoud 2012; Geddes 2011). A fő migrációs szervezetek közlései eredményeképpen két politikai irányzat jelent meg: az egyik az etikai toborzás gyakorlatát szorgalmazza, a másik pedig a cirkuláris migrációt és annak előnyeit hangsúlyozza. Ez utóbbit nagyobb konszenzus övezi, ${ }^{21}$ de ezzel kapcsolatosan is vannak kételyek, mert a jelenség mélyére ásva megvalósíthatatlannak tűnik a ,hármas nyertes” (a küldő-, a befogadó társadalom és a migráns) helyzetének megteremtése (Levatino \& Pecoud 2012; Lahav \& Lavenex 2013).

\footnotetext{
21 Az előbbi viszont gyakran vita tárgyát képezi, egyfelől éppen a fentiekben tárgyalt emberi jogok elvével való ütközése miatt. Másfelől az etikus toborzás egy 'képlékeny', megfoghatatlan indítvány, hiszen betartása önkéntes alapon müködik: semmilyen kényszerítő vagy szankcionáló eszköz nincs az érvényre juttatásuk szolgálatában (Cehan 2013).
} 


\section{A VIZSGÁLT MIGRÁCIÓS TÉR}

\subsection{Migrációs folyamatok és politikák a globalizáció korában}

A globalizáció kapcsolatba hozható regionális gazdasági egységek kialakulásával, amelyre jó példát szolgáltat az Európai Unió. ${ }^{22}$ Ezekre az egységekre a tőke, a munka és a munkaerő majdnem teljesen szabad áramlása, mozgása jellemző (Melegh 2012; Lavenex 2008). A globalizáció eredményeképpen gyorsan növekszik a határátlépések száma, avagy maga a migráció is globalizálódik, ami azt jelenti, hogy a nemzetközi vándorlás egyre több országot érint. Ez maga után vonja azt is, hogy kiszélesednek a mozgásban résztvevők jellemzői, vagyis a fejlett országokba belépők gazdasági, társadalmi és kulturális hátterüket tekintve tágabb spektrumon mozognak. Nő a mozgás volumene; a migráció elnőiesedik: már nem csak menekültként vagy családegyesítés céljából vándorolnak, hanem a munkaerö-migrációban is fontos szerepet töltenek be a nők; egyre több típusú migráció létezik; illetve a hagyományosan kibocsátó országok tranzit- és befogadó országokká válnak (Castles \& Miller 2009; Salt 2001; Hárs 2010).

Becslések szerint 2005-ben 200 millió ember élt a nem születési országában (Penninx et al. 2006). Európában a népesség 9,8 százaléka külföldi születésü volt 2013ban (United Nations, Department of Economic and Social Affairs 2013b). Dacára annak, hogy világszinten a fő migrációs áramlatok nem a fejlett országokra koncentrálódnak, hanem a fejlődő országok között zajlanak (Niessen 2000; Messina \& Lahav 2006; Demuth 2000), a bevándorlók számának növekedése a fejlett államokban számos kérdést és problémát vet és vetett fel a befogadó társadalmakban (Zolberg 2001; Castles \& Miller 2009). E mögött egy összetett jelenség áll, amelynek egyik aspektusa az, hogy a gazdaságpolitikában végbement neoliberális fordulat a jóléti állam hanyatlását eredményezte (Bauböck 2001; Castles 2012); a globalizáció mintegy átalakította a nemzetállam szerepét (Sassen 2007) ${ }^{23}$. Ez a változás a privatizációs- és individualizációs folyamatokban, és a közösségi szolidaritás szétszakadozásának trendjében ragadható meg. Ugyanakkor a csökkenő fertilitás, az öregedő népesség és a munka helyszínének és követelményeinek változásai egy erős keresletet teremtettek a bevándorlók iránt úgy az alsó, mind felső szakképzettségi szinten (Coleman 2006; Melegh 2011). A bevándorlás és letelepedés a befogadó társadalom számára nagyon gyors változásokat jelent, amelyek a bizonytalanság (uncertainty \& insecurity) érzetét

${ }^{22}$ Pries az EU alapját a transznacionalizmusban látja (Pries 2003).

${ }^{23}$ Lavenex a globális gazdaság feltételei között létező és müködő államot versenyállamnak nevezi, amely átvette a nemzeti kötődésủ jóléti állam helyét (Lavenex 2008) 
keltik. Így a bevándorlók válnak a globalizáció látható szimbólumaivá, ezért gyakran teszik felelőssé és vádolják őket a fenyegető és felfoghatatlan változásokért; vagyis ők a globalizáció ügynökei és áldozatai egyszerre (Castles 2012; Bauböck 2001). A befogadó társadalmak tagjai a jóléti rendszerük és társadalmi kohéziójuk veszélyeztetőit látják a bevándorlókban, és nyomást gyakorolnak a kormányzati szervekre a bevándorlás korlátozása érdekében. A politikai döntéshozók az állampolgárok igénylései, a csökkenő népességszám és a fenntartható gazdasági fejlődés kényszere, illetve különböző érdekcsoportok (pl. nemzetközi vállalatok) többirányú nyomása alatt törekednek határaik egyre szigorúbb ellenőrzésére, a mozgás szabályozására, vagyis az egyensúly megtalálására (Juss 2007). Juss szerint egy racionális bevándorlási politika egyaránt tekintettel van a hazai munkaerőpiac szükségleteire és a kedvezőtlen közvéleményre, a nemzetbiztonságra és az emberi jogok kötelezettségeire, az ország érdekeire és a fejlődő országokkal való nemzetközi szolidaritásra. Mivel ezek gyakran egymást kizáró intézkedéseket igényelnek, a migrációs politikáknak ugyancsak szűk mezsgyén kell lavírozniuk.

Európa hagyományosan egy kibocsátó terület volt, amely tendencia a 60-70-es évek folyamán változott meg, és nagy, addig kibocsátónak számító országok váltak rövid időn belül célországokká (Castles \& Miller 2009). Az Európai Unió migrációs politikája kétirányú: míg belül, a tagországok között az egyének szabad mozgása biztosított, kifelé a kívülről jövők növekvő ellenőrzése és korlátozása van érvényben (Recchi 2008). A globalizáció egyenlőtlenségeket megerősítő/növelő hatásai látható ebben is, hogy bizonyos régiókat és társadalmi csoportokat belefoglal a világkapitalista piaci kapcsolatokba, másokat pedig kizár (Castles 2012; Glick Schiller et al. 1995). ${ }^{24}$

Nyílt rendszer lévén, az EU csak aktív migrációs politikával befolyásolhatná a vándorlást, ez viszont a demokratikus alapvető emberi jogok sérelmével járna. A klasszikus értelemben vett nemzetközi migráció szabályozását csak az Unión kívüli országokkal szemben alkalmazhat, mert a tagállamok közötti vándorlás belső migrációnak, mobilitásnak számít (Kisvarga 2005; Wismar et al. 2011). A tagállamok több módszert is alkalmaznak a migráció „exportjának” elősegítésére és a határellenörzésre: a keleti határokon ütközőzónákat hoznak létre, különböző szerződéseket kötnek és együttmüködéseket építenek ki (Wallace et al. 2001; Morris 1997).

${ }^{24}$ A migráció osztályalapú szelekciós mechanizmusáról bővebben korábban, a 3. fejezetben esett szó. 


\subsection{Román- magyar migráció: általános trendek}

Bizonyos, korábban kibocsátó közép-kelet-európai országok egyre inkább egy bevándorlási régióvá alakulnak át, amelynek Magyarország is részét képezi (Melegh 2012); jóllehet az utóbbi időben a trend megfordulni látszik és Magyarország egyre növekvő ütemben bocsát ki migránsokat (SEEMIG 2014). Némely újabban csatlakozott EU tagállam egyszerre tölti be a tranzit-, a kibocsátó- és a célország szerepét (Penninx et al. 2006). Hárs egy longitudinális vizsgálatából azt a következtetést vonja le a rendszerváltást követő közel 2 évtized tapasztalatai alapján, hogy Magyarország esetében a migrációs folyamatokban nagyobb szerepet játszottak a migrációs politikák látványosabb a hatásuk -, mint a munkaerö-piaci kereslet alakulása. Jelenleg a migrációs politikák nem korlátozóak, sokszor inkább csak az elkedvetlenítést szolgálják (Hárs 2010).

A rendszerváltás óta eltelt bő két évtized során nagyon sok migrációval, és elsősorban - befogadó országgá alakulván - bevándorlókkal kapcsolatos kutatás született Magyarországon. Túlnyomó részük a határon túlról érkező magyarok társadalmi-demográfiai összetételét, beilleszkedését vizsgálta, főként az erdélyi magyarokét, mivel ők jelentették a legnagyobb volumenü bevándorló csoportot (Gödri \& Tóth 2005; Tóth 1994; Cseresnyés 1991). Ennek köszönhetően számos ismeret halmozódott fel az Erdélyből érkező migránsok kor- és nem szerinti összetételéről és azok változásáról (különböző időszakokban érkező bevándorlók), iskolázottsági szintjéről, anyagi helyzetéről, a vándorláshoz vezető fő motivációikról és azok változásairól, munkaerő-piaci helyzetükről, letelepedési célterületeikről stb. Mindezek alapján röviden megállapítható, hogy a rendszerváltást közvetlenül megelöző és követő egy-két évet felölelő időszakban beáramlott nagy számú menekült közel háromnegyede Romániából érkezett, többsége magyar anyanyelvü volt, illetve viszonylag magas arányban jöttek értelmiségiek (Tóth 1994; Gödri \& Tóth 2005). Az ezután következő két évtizedben, - amikor már nem menekülés, hanem bevándorlás zajlik -, leginkább a munkaerő migráció dominált, amit egyre növekvő arányban egészített ki a családegyesítési és tanulási célú migráció. ${ }^{25} \mathrm{~A}$ kezdeti magasabb férfi arányt - a nők egyre növekvő részvételével - a nemek kiegyenlítettsége váltotta fel; a bevándorlók átlagéletkora növekedett, mivel a fiatal munkaképes korú korosztály vándorlása mellett megjelent a nyugdíjas migráció, így egyre kevésbé fiatalítják a helyi népesség átlagéletkorát; illetve növekszik az alacsonyabban iskolázott és kevésbé képzettek,

25 Jóllehet a tanulás és munkavállalás gyakran egymásba fonódik, illetve egy kétlépcsős migrációs folyamatként is jellemezhetö (Hawthorne 2012). 
szakképzetlenek aránya. Többnyire a föváros és az azt övező agglomerációs terület, valamint a román határmente jelentik a fő célterületeket. Fogadtatásuk az anyaországiak részéről időben - és a különböző politikai, gazdasági és társadalmi tényezők és azok alakulásai függvényében - változó volt, integrációjuk viszont a közös nyelvnek köszönhetően viszonylag könnyen végbement, nagy számban magyar állampolgárok lettek. $^{26}$

Mindezek mellett - amint arra szakértők felhívják a figyelmet - nem hagyható figyelmen kívül, hogy a nemzetközi migráció egy sajátos formájával állunk szemben, amikor az egyazon nemzet tagjai között az egyének földrajzi mobilitása nélkül álltak fel új országhatárok ${ }^{27}$ (Gödri 2010; Melegh 2011). Tehát - mint korábban utalás történt rá - a vizsgált időszakban zajló migráció tulajdonképpen a diaszpórából az anyaországba való visszatérésként is felfogható, bár Magyarország egy ideig nem alkalmazott olyan mértékű megkülönböztető bánásmódot az áttelepülő határon túli magyarokkal szemben, mint amilyent Németország tanúsított a „hazatérő” németek irányában (Portes \& Böröcz 1989; Brubaker 1998; Fox 2003). A 90-es éveknek a határon túli magyarságot érintő politikáját a „szülőföldön boldogulás” elve vezérelte (Tóth 2000:251), ily módon az otthon maradt kisebbségi magyarokat bizonyos kiváltságok illették meg az anyaország részéről (Cseresnyés 1991; Brubaker 1998; Feischmidt \& Zakariás 2010). Az egyszerüsített honosítási eljárást érintő törvényt 2010-ben fogadta el a magyar Országgyülés.

Kezdetben a Romániából Magyarországra irányuló migrációt az etnikai migráció kategóriába sorolták a kutatók, a közös anyanyelvre és nemzetiségre, a nemzeti összetartozás szerepére, a kibocsátó országon belüli etnikai konfliktusokra hivatkozva (Sandu 2000a; Gödri 2004). Melegh szerint a határon túli magyarok Magyarországra vándorlása csak részben magyarázható az ország történelmi területi felosztásával és a határok megváltoztatásához kötődő etnikai privilégiumokkal; a globalizáció is fontos szerepet játszott benne. Mivel az anyaországban korábban megkezdődött a piaci átalakulás, mint Romániában, a jövedelmi különbségek - amint azt az alábbi ábra (1. ábra) is szemlélteti - további húzó hatást fejtettek ki a történelmi kapcsolatokon túlmenően, ${ }^{28}$ megnövelve a vándorlási hajlandóságot. A globalizációs hatások nagy fontosságát látszanak alátámasztani egyfelől a magyarországi gazdasági válság

${ }^{26}$ Ez csak nagyon vázlatos, és nem teljes körű szemelgetés a témában folyt kutatások sokaságából. Bővebben lásd például: (Tóth 2004; Németh et al. 2011; M. Szakáts 1995; Kincses 2010; Gödri \& Tóth 2005).

${ }^{27}$ Tóth Pál Péter „virtuális migrációnak” nevezi ezt a jelenséget (Tóth 2003). Ez azonban nem kizárólag Magyarország esetében létező sajátosság, hiszen több más ország esetében megfigyelhető mint a korábbi birodalmak, államok felbomlásának kísérőjelensége.

28 Magyarországon jóval magasabb volt a havi átlagbér, mint a szomszédos országok többségében (bővebben lásd: (Cseresnyés 1991)). 
következtében kialakult munkaerő migráció visszafelé irányuló tendenciái, másfelöl a nyugat-európai országokban elérhető nagyobb komparatív előnyök hatására kialakult új, erdélyi munkaerő-migrációs hálózatok (Melegh 2011).

1. ábra: Magyarország és Románia gazdasági fejlettsége 1988- 2013 közötti idöszakban $\left(G D P / f^{\prime \prime}\right)$

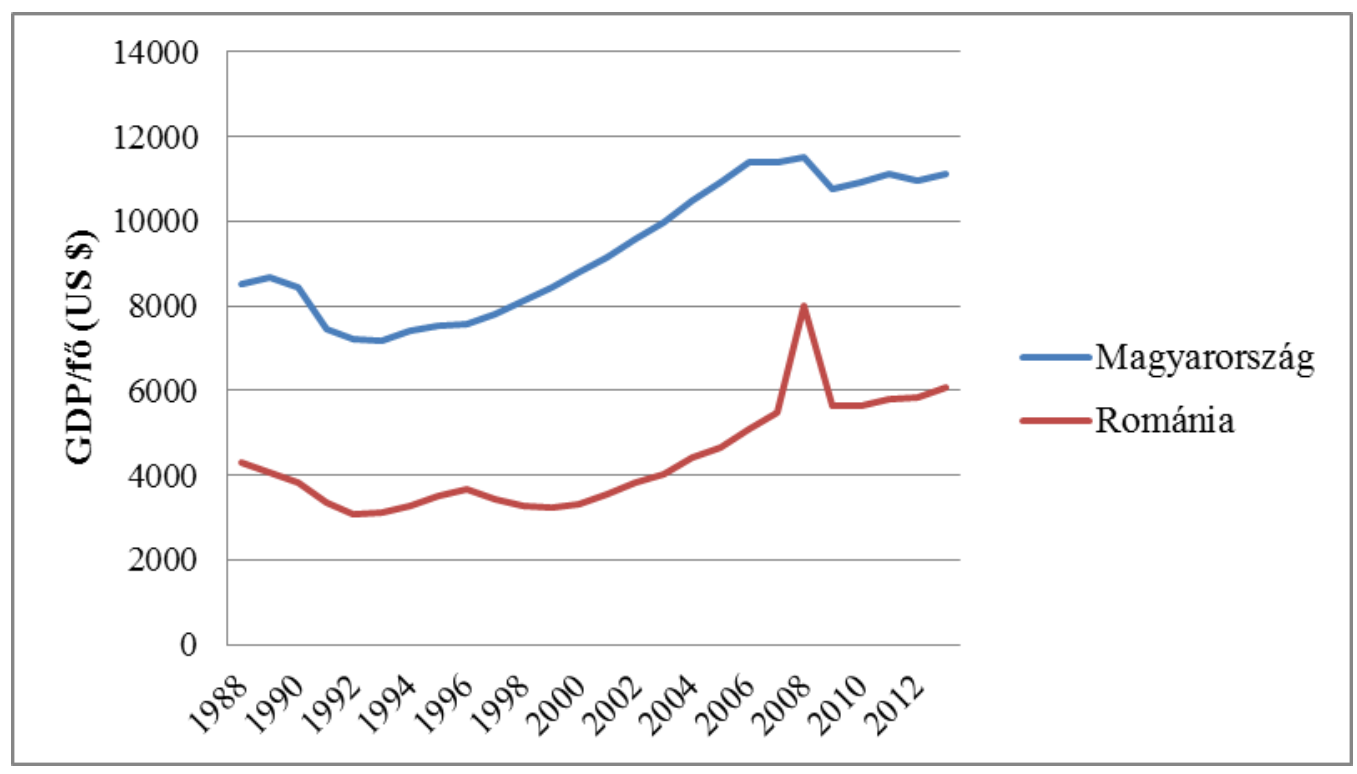

Forrás: World DataBank, Development Indicators (WorldBank 2014)

Ez az eltolódás a nyugati országok irányába fokozatosan ment végbe. Az 19891993 közötti időszak az etnikumok és vallási hovatartozás korszaka: német, magyar és zsidó kivándorlók hagyták el Romániát az anyaországba való hazatérés céljából, főleg Erdély területéről. 1994 után az etnikai kritérium átalakult (csökkent az etnikai migránsok aránya), amivel párhuzamosan kialakult a cirkuláris vagy körforgásos migráció (Sandu 2000a; Baldwin-Edwards 2008). Ezt a változást nagyon jól tükrözik a Magyarországra bevándoroltak körében végzett kutatások, hogy míg a rendszerváltást megelőző időszakban a menekülések okai között politikai és gazdasági tényezők is jelen voltak, a 90-es években a kisebbségi hátrányok említése csökkent, és felerősödtek a gazdasági motivációk (M. Szakáts 1995; Gödri 2004; Gödri 2010). Az ezredfordulót követően az anyaországban élö, határon túlról érkező magyar bevándorlók körében a leggyakrabban említett okok a bizonytalan jövőkép, a gazdasági megfontolások és a családegyesítés voltak. Ezen belül a romániai bevándorlók esetében a legfontosabb motivációt a család létfeltételeinek a javítása jelentette, amit az elemzők ,innovatív” migrációnak neveztek (Gödri \& Tóth 2005; Gödri 2004). Ekkor már kis arányú az etnikai migránsok aránya, és esetükben is inkább a kisebbségi lét és az ahhoz kapcsolódó bizonytalan jövőkép elutasítása volt motiváló (Gödri 2010). 
Az ezredfordulóra tehát a migrációs hálózatok Romániában mindinkább „deetnicizálódtak" (Kiss \& Csata 2004; Constantin et al. 2004; Sandu 2000b), ami együtt járt Magyarországról Nyugat-Európa irányába való terjeszkedésükkel. A nyugati országok gazdaságilag nagyobb komparatív előnyöket kínálhatnak a migráns munkavállalók számára (lásd 2. ábra). Ugyanakkor az etnicitás fontossága az ErdélyMagyarország térségben való mozgásban továbbra is központi kérdése maradt az elemzéseknek. Megjelent az etnicitás szerepének újraértelmezése, amelyben konvertálható tőkeként jellemzik, mivel vonzó tényező lehet a kedvező fogadtatás miatt és segíti a beilleszkedést (Brubaker 1998; Horváth 2002; Kiss \& Csata 2004; Feischmidt \& Zakariás 2010).

Megváltoztak a romániai migráns hálózatok: nem etnikai, rokoni és vallási alapon, hanem közösségi, szomszédi, baráti és érdeklődési alapon nyugvó hálózatok jöttek létre (Sandu, 2003a). Tehát a magyarok számára is elérhetővé váltak a rendszerváltás után kialakult román migráns hálózatok, viszont a két etnikum hálózatai nem olvadtak egymásba, amire a célországok különbözőségei utalnak (Gödri \& Kiss 2009). A magyarok által leginkább kedvelt célterületek: Németország, Magyarország, Ausztria és Észak-Amerika, a románok inkább Olaszországot és Spanyolországot választják (Gödri \& Kiss 2009).

2. ábra: A romániai migránsok fö célországainak gazdasági fejlettsége (GDP/fó)

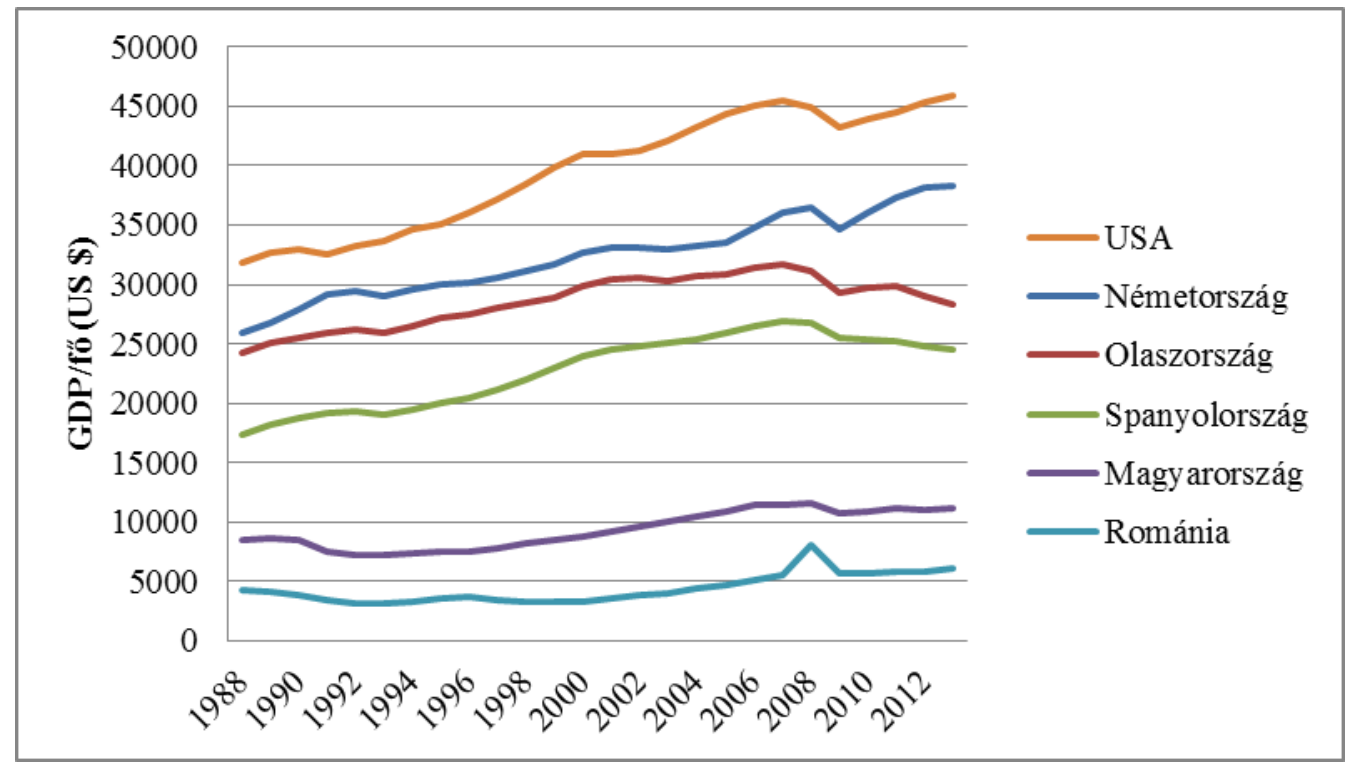

Forrás: World DataBank, Development Indicators (WorldBank 2014)

Viszont ennél egy kissé árnyaltabb a kép: a tömbben élő erdélyi magyarság a 90-es években a többségi népességnél nagyobb arányban vett részt a nemzetközi migrációban Magyarországon keresztül, és az így kialakult hálózatok részben megakadályozták a többségben élő magyarokat abban, hogy a még nagyobb vonzó hatást gyakorló Nyugat- 
Európa felé mutató hálózatokba bekapcsolódjanak. Másfelől viszont a szórványterületeken élők kapcsolathálójában nagy súlyt viselnek a többségiek, így migrációs stratégiáik és hálózataik az övékéhez hasonlóan alakultak (Kiss 2012).

\subsection{Erdély: migráns potenciálok}

Az alábbiakban a Romániából Magyarországra irányuló migráció vizsgálata következik. Mivel nemzetközi migrációs jelenségről van szó, ezért az elemzésben elválaszthatatlan a két ország egyidejü, párhuzamos szemlélete; amint az az elöbbi alfejezetben is megfigyelhető volt. Ez az elméleti rész a migrációs rendszer bemeneti oldalával, a migrációs potenciállal foglalkozik. A migrációs potenciál a jövőben várhatóan bekövetkező vándorlás becslésére szolgál, és nem más, mint a kivándorlást vagy külföldi munkavállalást jelző szándék (Sik 2003). Értelemszerü, hogy a migrációs szándék és a tényleges migráció közötti kapcsolat esetleges, de valószínüleg nagyobb arányban mozdulnak azok, akik tervezik. A migrációs tervek realizálódása a vándorlás során konvertálható speciális tőkék meglététől függnek, amelyek a társadalmon belül egyenlőtlenül oszlanak el (Kiss \& Csata 2004). A migrációs irodalomnak a potenciál mérésével való foglalkozásának hátterében az a felfogás áll, hogy a migrációs szándékok olyan figyelemre érdemes társadalmi tények, amelyek egy társadalmi csoport szociálpszichológiai állapotáról és a megkérdezettek cselekvési stratégiáiról nyújtanak információt (Gödri \& Kiss 2009).

Már említésre került, hogy számos migrációs potenciál-kutatást végeztek az erdélyi magyarok körében, erdélyi és magyarországi kutatók egyaránt. Ezek együttesen megállapítják, hogy az erdélyi magyar migrációs potenciált, illetve a külföldi munkavállalási vagy kitelepedési szándékot az alábbi tényezők befolyásolják: a nem, az életkor, az iskolai végzettség, gazdasági aktivitás, a személyes külföldi rokoni és baráti kapcsolatok, a korábbi külföldi migrációs tapasztalat - akár közvetett formában is (a környezetében élők korábbi migrációja) -, a vagyoni helyzet, idegen nyelv ismerete, a jövőről alkotott kép, a szülőföldhöz való kötődés, a származási település, az elégedettség mértéke, a településnagyság, illetve a településen élő magyarság aránya (Sik \& Örkény 2003; Kiss \& Csata 2004; Simonovits 2003).

Az új évezred kezdetén Erdélyben a férfiak és nők hasonló arányban tervezték a migrációt Magyarországra, ${ }^{29}$ és azóta a nők részvételi aránya növekszik, ami a vándorlás elterjedtségére (Massey et al. 1994) és a hálózatok bejáratottságára utal (Sik

\footnotetext{
${ }^{29}$ Bár a migráció különböző formáinál eltérések mutatkozhatnak: például a férfiak nagyobb arányban tervezték a rövidtávú (egy évnél rövidebb) munkavállalást (Örkény 2003).
} 
\& Simonovits 2003; Hárs 2010). Ezért várakozásaim szerint a végzős hallgatók körében is a migrációs potenciál nagysága hasonló a két nem esetében. Az életkor növekedésével csökken a migrációs hajlandóság, vagyis a fiatalabbak inkább terveznek külföldre vándorlást (Örkény 2003). Mivel jelen esetben egy fiatal, életkor szerint viszonylag homogén csoportról van szó $^{30}$ várhatóan a migrációs potenciáljuk magasabb, mint az átlagos erdélyi magyar migrációs potenciál. A magasabb iskolai végzettség - az idegen nyelv ismeretéhez hasonlóan - ösztönzőleg hat a külföldi munkavállalási szándékra, mivel ezek olyan humán tőkét jelentenek, amelyek elméletileg könnyen transzferálhatók egyik országból a másikba (Favell et al. 2008; Gödri \& Kiss 2009). ${ }^{31}$ És nem csak a terveket befolyásolják, hanem a célország kiválasztását is: a neoklasszikus közgazdaságtan mikroelmélete alapján a potenciális migráns inkább oda megy, ahol számításai szerint humán tőkéje befektetésének a várható megtérülése a legnagyobb (Massey et al. 1993). Ennek értelmében - és tekintetbe véve azt is, hogy az Európai Unió munkaerőpiaca nyitott az egészségügyi dolgozók előtt, - az idegen nyelv ismerete valószínüleg a nyugatabbra fekvő országok irányába tereli a végzősöket, vagyis Magyarország kevésbé vonzó a számukra. Már a tíz évvel ezelőtti adatok is arra utaltak, hogy az alacsony kulturális tőkével rendelkezők választják inkább Magyarországot (Örkény 2003), amely tendencia a későbbiekben megerősödni látszik. Az eddigi migrációs potenciál felmérések alapján a vándorolni szándékozó erdélyi magyarok csoportja a 2000-es évek közepétől kettéválik: míg Nyugat-Európába a magasabb anyagi és humán tőkével és a nagyobb társadalmi státussal rendelkezők (akik felsőfokú végzettséggel, idegen nyelv-ismerettel, magas jövedelemmel, és nagyvárosi származással rendelkeznek), addig Magyarországra a rosszabb helyzetben levők (falusi hátterü, alacsonyan képzettek, fizikai munkások, romák) igyekeznek (Kiss 2012). Ezek alapján azt feltételezem, hogy az alacsonyabb és közepes státusú, tehát a felfelé mobil végzős hallgatók inkább választják Magyarországot, mint Nyugat-Európát.

A román nyelv megfelelő szintű ismeretének hiánya - amelyet a kutatók a nyelvikulturális integrálatlanság jelenségeként írnak le - ugyancsak a migráció irányába hat, mivel a tágabb társadalmi integráció, mint például a munkaerő-piaci, igényli a nyelvi integrációt is (Kiss \& Csata 2004). A jó román nyelvtudással való rendelkezés növeli a migráció esélyét Nyugat-Európa irányába, Magyarországgal szemben (Gödri \& Kiss 2009).

\footnotetext{
${ }^{30}$ Bővebben lásd a Minta leírásáról szóló részt.

${ }^{31} \mathrm{Ez}$ természetesen függ attól, hogy milyen földrajzi térségen belül történik a mozgás, és hogy milyen kompetenciákról van szó. A harmadik országból érkező bevándorló esetében gyakran felmerül a státusinkonzisztencia vagy alulfoglalkoztatottság problémája.
} 
A gazdasági inaktivitásnak ugyancsak ösztönzö hatása van a Magyarországra irányuló migrációra, bár leginkább a munkanélküliek szándékoztak az anyaországban munkát vállalni vagy bevándorolni (Sik \& Simonovits 2003; Gödri \& Kiss 2009). Mivel jelen esetben nappalis hallgatókról van szó, a szülők társadalmi státusának (iskolai végzettség és foglalkozás alapján képzett mutató) hatása került vizsgálatra; jóllehet korábbi felmérések alapján az apa iskolai végzettségével mért családi státus szerepe elhanyagolható $^{32}$ (Kiss \& Csata 2004). A közvetlen vagy közvetett migrációs tapasztalatnak a vándorlási szándékra gyakorolt hatása már régen felkeltette a kutatók figyelmét, akik megállapították, hogy minél nagyobb valakinek a személyes, illetve a közvetett migrációs tapasztalata, annál inkább nő annak az esélye, hogy visszatérjen külföldre ${ }^{33}$ (Massey et al. 1994). Az erdélyi magyarok körében a migrációs szándék egyik legfontosabb magyarázó erejü tényezője a korábbi külföldi munkavállalási tapasztalat (Örkény 2003). Mivel a vizsgált népesség fiatal és többségük feltételezéseim szerint megszakítás nélkül folytatta tanulmányait, ezért nem kérdeztem rá a migrációs tapasztalatra. $^{34}$

A külföldre mutató családi/ rokoni- baráti kapcsolatok kutatása központi szerepet játszanak manapság a hálózatelemzésekben. Amint az elméleti részben már említésre került, a migrációs kapcsolatok társadalmi tőke gyanánt müködnek, amelyek a mozgás irányába hatnak, illetve mobilizálásuk révén csökken a migráció költsége és kockázata (Castles \& Miller 2009; Portes \& Böröcz 1989; Tilly 2001; Portes \& Sensenbrenner 2001; Gödri 2010). Továbbá segítik az információ-áramlást, hozzájárulva az egyén aspirációinak megváltozásához (de Haas 2011; Fawcett 1989). A korábbi migrációs potenciál-kutatások azt jelzik, hogy az erdélyi magyarok migrációs terveire szignifikánsan hat a kapcsolati tőke, de legnagyobb befolyása a családi kapcsolatoknak van, legalábbis ami a szándékoknak a realizálását jelenti; viszont a fiatalok elsősorban a migráns baráti kapcsolatok mentén mozdulnak el (Gödri \& Kiss 2009; Gödri 2010). Feltételezem tehát, hogy inkább tervezik a külföldi munkavállalást azok a hallgatók, akik rendelkeznek migráns kapcsolati tőkével, illetve migráns baráti kapcsolattal.

\footnotetext{
${ }^{32}$ Magyarországon Ph.D. képzésben részt vevő, határon túlról érkezett magyar hallgatók körében végzett kutatás eredményei alapján viszont az apa iskolai végzettségének hatása az Erdélyből jövők esetében a legmagasabb. Ám az elemzők azt is hozzáfüzik, hogy a szülöi háttér meghatározó szerepe csak adott iskolázottsági szint felett érvényesül (Papp \& Csata 2013).

${ }^{33}$ Lásd a kumulatív okság alfejezetben.

34 A kérdőív összeállítása során sajnos nem vettem figyelembe a tanulmányi mobilitást elősegítő különbözö ösztöndíjprogramok szerepét, melyek révén ugyancsak szakmai tapasztalat szerezhetö. Az interjúkból kiderül, hogy némely esetben milyen meghatározó szerepe tud lenni egy külföldön töltött szakmai gyakorlatnak. Egy magyarországi, hasonló összetételü populáción (SOTE hallgatók körében) végzett kutatás eredményei alapján a korábbi külföldi tanulmányút nem növelte a hallgatók migrációs szándékát; viszont a saját külföldi munkatapasztalatuk igen (DPR 2013).
} 
A vagyonosság hatása leginkább a szubjektív anyagi helyzet révén ragadható meg, mert az egyént döntéseiben nem feltétlenül a valóság vezérli, hanem az, amilyennek vagy ahogyan a valóságot érzékeli (Bose 2012; Demuth 2000). Az anyagi helyzet kétoldalú dologként müködik: mint elégséges vagy bőséges gazdasági tőke a külföldi munkavállalás ellenében hathat (Sik \& Örkény 2003), másfelől pedig lehetővé teszi a vándorlási szándékok megvalósítását. Viszont tovább árnyalja a képet a relatív depriváció jelensége: mivel az egyén saját gazdasági jólétét másokéhoz viszonyítva ítéli meg, gazdasági állapota változatlansága esetén is romlást észlelhet, amennyiben a környezetében élőké javul, például a külföldi munka eredményeképpen. Az Erdélyben élő potenciális migránsok esetében nagyon fontos szerepet játszik a lecsúszástól való félelem és az élethelyzettel való elégedetlenség (Kiss \& Csata 2004; Gödri \& Kiss 2009). Az elégedetlenséget a „migrációs potenciál motorjának” nevezi a magyar szerzőpáros (Sik \& Örkény 2003, 191), ezért várakozásaim szerint az elégedetlenebbek inkább tervezik a külföldi munkavállalást. Viszont az elégedetlenség fakadhat és párosulhat alacsony gazdasági tőkével, amely gátló tényező a tervek megvalósításában (de Haas 2011). Ezért az elégedetlenebbek motiváltabbak lehetnek a külföldi munkavállalásra, viszont a szándék kimenetele még inkább kérdéses, mint a bőségesebb anyagi tőkével rendelkezők esetében.

Korábbi kutatások tapasztalatai alapján a szülőföldhöz való kötődés bizonyult a legfontosabb helyben tartó tényezőnek, és fordítva: minél gyengébb volt ez a kapcsolat, annál inkább nőtt a migráció tervezésének a valószínűsége (Sik \& Örkény 2003). Később a család vette át ezt a horgony-szerepet (Gödri \& Kiss 2009), ami a jóléti migrációs motivációk előretörésével hozható összefüggésbe - míg az etnikai eredetü okok, a szülőföldhöz ragaszkodás háttérbe szorult. ${ }^{35}$ Jelen kutatás fókuszában az állt, hogy mely tényezők - beleértve a szülőföldet és a családot is - és meggyőződések játsszák a visszatartó szerepet az egyén döntésében.

A jövőkép eltérő észlelése (mint: az országban élő fiatalok vagy a kisebbségi magyarság jövőjét, illetve a szakmában pályakezdők anyagi helyzetét érintő attitüdök) különböző hatásokhoz és döntésekhez vezethet. Amikor az egyén optimistán szemléli a jövőt, valószínűleg maradni szándékozik (vagy rövidtávú migrációt tervez tapasztalatszerzés vagy kalandvágyból). Viszont ha pesszimistán látja jövőjét és nem lát módot a változásra, akkor kivonul, tehát a „lábával szavaz”, máshol keresi céljai megvalósítását (Hirschman 2001). Festinger egy árnyaltabb képet nyújt az egyén választáshoz való attitüdjéről a kognitív disszonancia redukció elméletében. Az

\footnotetext{
${ }^{35}$ A család (párkapcsolat) szerepe elsődleges volt a legtöbb migráns narratívájában is.
} 
egyénben minden döntési helyzetben, amikor választania kell két olyan lehetőség között, amelyeknek pozitív és negatív következményei egyaránt vannak, feszültség, úgynevezett kognitív disszonancia alakul ki. Ez többféle módon csökkenthető, amelynek leggyakoribb formája a választási lehetőségekkel kapcsolatos információk megváltoztatása. Ez azt jelenti, hogy a döntésre kényszerülő egyén vagy a választott opciót igyekszik jó színben feltüntetni a velejáró negatív következmények lebecsülésével, vagy az elvetett alternatíváról való negatív ismereteit próbálja minél inkább alátámasztani - a „savanyú a szőlő” mechanizmus (Festinger 2000). Tehát a pozitív jövőkép és a helyben maradás közötti kapcsolat összetettebb, mint elsőre tűnik: jelenthet valódi optimizmust, illetve a migráció lehetőségének hiányában az előtte álló jövő megszépítését. 


\section{MÓDSZERTAN}

A Bevezetőben már történt utalás arra, hogy a nemzetközi migráció kutatása interdiszciplináris megközelítést igényel, mivel maga a folyamat is interdiszciplináris: összekapcsolódnak a különféle társadalmi viszonyok és cselekvési formák, és ezért a megragadás és megértés különböző módjait igényli (Bose 2012). Részben ennek tulajdonítható a migrációs elméletek sokfélesége (a közgazdaságtantól, a szociológián át a politika-tudományokig terjedő eredettel), mindenik a maga szemléletmódjával és módszerével az összképnek egy-egy kis szeletét adva.

A kutatás arra a központi kérdésre irányul, hogy ki hogyan szándékszik belépni és mozogni a vizsgált térben, amely elsősorban Erdélyt és Magyarországot jelenti. A kérdésre a választ mikro- és makro szinten kerestem; ez utóbbi magába foglalja a makrogazdasági viszonyokat (különbségek, egyenlőtlenségek), a történeti kapcsolatokat és az intézményi tényezőket. Kutatásomban több elméletre is alapoztam. Leginkább a nemzetközi vándorlás globalizációs és transznacionális elméleteire, a mezo- struktúrák migrációs hálózat elméleteire, a neoklasszikus közgazdaságtan húzó-taszító elméleteire, a határon túl élő magyarság vándorlásával és migrációs potenciáljával foglalkozó kutatásokra építettem.

A feltárni kívánt jelenség nagy kihívást jelentett nem csak sokoldalúsága miatt, hanem azért is, mert egyszerre tekint múltba és jövőbe. A vizsgált bő két évtized alatt (1990-től 2012. júniusáig) nagy társadalmi, gazdasági és politikai változások mentek végbe (legfontosabbak: az 1989-es rendszerváltás hatásai, illetve Romániának az Európai Unióhoz való csatlakozása 2007. januárjában, a 2008-ban bekövetkezett gazdasági válság), melyek az egyén számára utazási szabadságot hoztak és a nemzetközi vándorlás útjában álló politikai akadályok eltörlését eredményezték. Hogyan alakult ebben a sokrétüen változó kontextusban az erdélyi egészségügyi dolgozók Magyarországra irányuló migrációja? Miért vándorolnának el a jövő egészségügyi dolgozói és mi az, ami otthon tartaná öket, illetve milyen feltételek megváltoztatása révén lehetne maradásra bírni őket? Hogyan szándékoznak belépni és mozogni a migrációs térbe(n)? Melyek a lehetséges célországok és tagjaik-e azok irányába mutató hálózatoknak? Mikorra és milyen távra tervezik a külföldi munkavállalást, illetve hogyan hatnak a vándorlási szándékokra a különböző társadalmidemográfiai tényezők és különböző attitüdök? Szerepet játszanak-e döntéseikben a globális hierarchiák, illetve verbalizálják-e ezeket? 
Migrációs potenciál alatt a hallgatók külföldi munkavállalási szándékát értem. A nyers migrációs potenciál megnevezés egyszerüen ezeket a szándékokat, migrációs terveket foglalja magában; a tisztított migrációs potenciál pedig a jelzett terv megvalósítása érdekében tett beruházásokat is figyelembe véve tesz kísérletet a szándék komolyságának mérésére (Sik 2003).

\subsection{Alkalmazott módszerek}

Kutatásomban a triangulációt alkalmaztam, mely révén a jelenség jobb megértésére törekedtem, a makro- és mikroszintü, kvantitatív és kvalitatív vizsgálatok ötvözésére. Ehhez egyrészt a rendelkezésre álló statisztikai adatokat dolgoztam fel - azok mindenféle korlátozottságának tudatában -, kiegészítve Magyarországon élő, Erdélyből bevándorolt orvosokkal/ápolókkal készült interjúkkal. Ezek a már vándoroltakkal készített interjúk részben segítettek feltárni mikro szintü tényezőket: bizonyos migrációs motivációkat és döntési mechanizmusokat, amelyek a számadatokból nem derülnek ki. Továbbá hozzájárultak a kérdőív előkészítéséhez a kérdések megfogalmazásával, ${ }^{36}$ mert a migrációs potenciál kutatásához - a bevett szokás szerint - surveyt alkalmaztam. A kérdőív révén gyüjtött adatokat kereszttáblák és logisztikus regresszióelemzés segítségével elemeztem. Végül pedig félig strukturált interjúkat készítettem a végzős hallgatókkal, amelyek részben a kérdőíves kutatás eredményeit gazdagítják, részben pedig lehetőséget nyújtanak a migrációs motivációk és döntési mechanizmusok esetleges változásának vizsgálatára.

\subsubsection{Statisztikai adatok: nyilvántartások}

Az adathiány - annak ellenére, hogy viszonylag magas szinten szabályozott és engedélyekhez kötött szakmáról van szó -, illetve a különböző nyilvántartások adatai közötti eltérések a kutatásban érintett két ország számára is súlyos problémát jelentenek (Galan et al. 2011; Eke et al. 2009; Eke et al. 2011). További nehézséget okoznak az adatok körül a különböző jogszabályváltozások; valamint az uniós csatlakozás eredményeképpen leegyszerűsödött ügyintézés következtében a migráció kevésbé nyomon követhető, illetve a szekunder vagy tercier migráció nem mérhető. Mindezek figyelembe vételével a leghasznosabb eszköznek a befogadó országok nyilvántartásai bizonyulnak. A Központi Statisztikai Hivatal adattára olyan foglalkozási kategóriákkal dolgozik a bevándorlók kapcsán, amelyek nem tették lehetővé az egészségügyi

\footnotetext{
${ }^{36}$ Az interjúalanyok megtalálása és megkeresése az elérhetési nehézségeik, illetve szűkös időkorlátaik miatt időben elhúzódott, azaz több hónapot vett igénybe az adatfelvétel. Így a két típusú kutatás (interjú és survey) időben részben fedi egymást.
} 
dolgozók beazonosítását és leválogatását. A Bevándorlási és Állampolgársági Hivatal nem bocsátott rendelkezésre adatokat. A Szociális és Munkaügyi Minisztériumhoz tartozó Állami Foglalkoztatási Szolgálat intézménye, amelyet 2009-ben kerestem meg, csak 2000-től tudott adatokat szolgáltatni, amiből mindössze az orvosok számát tudtam kiszürni. 2013-ban felvettem a kapcsolatot a Magyar Egészségügyi Szakdolgozói Kamarával, ahol kezdetben azzal bíztattak, hogy az átvándorolt szakdolgozók adatai hozzáférhetőek az Oktatási Hivatal Magyar Ekvivalencia és Információs Központ archívumából. Megkeresésemre a Hivatal főosztályvezetője közölte, hogy nem rendelkeznek az igényelt adatokkal a kutatáshoz szükséges bontásban. ${ }^{37}$ Végül minden szál az Egészségügyi Engedélyezési és Közigazgatási Hivatalhoz vezetett (a Magyar Orvosi Kamarából is), amely 2008-ban lett létrehozva az egészségügyi dolgozók nyilvántartásainak központosítása céljából. A rendszerváltás óta eltelt két évtized egészségügyi dolgozókat érintő migrációs folyamatának elemezéséhez az EEKH által rendelkezésemre bocsátott adatokat vettem alapul ${ }^{38}$.

Ezek a tapasztalatok reform-igényeket vetnek fel, hiszen a politikai érdeklődés nem elégíthető ki ilyen nyilvántartásokkal, adathiánnyal.

\subsubsection{A kérdöív ${ }^{39}$}

A kérdések összeállítását elsősorban az erdélyi magyar migrációs potenciál kutatások (Örkény 2003; Sik \& Örkény 2003; Sik 2003; Kiss \& Csata 2004; Gödri \& Kiss 2009), a magyarországi orvosok külföldi munkavállalási szándékait vizsgáló kutatások (Eke et al. 2009) és a romániai egészségügyi dolgozók migrációja témakörében született

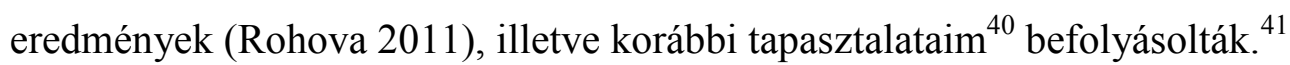

A külföldi munkavállalási szándékot két kérdéssel vizsgáltam, ${ }^{42}$ amelyből az első inkább a tágabb értelemben vett szándékra, a második pedig a határozottabb tervekre irányult. ${ }^{43}$ A migrációs tervek megvalósítása érdekében tett lépések vizsgálata ${ }^{44}$

\footnotetext{
37 Az 1990-2007 közötti időszakban Romániából érkezett és ekvivalencia vizsgát tett szakdolgozók adatait igényeltem naptári év, nem, szak, és lehetőség szerint a diplomát kiállító intézmény szerinti bontásban.

${ }^{38} \mathrm{Az}$ adatokat egy későbbi fejezet ismerteti (lásd: 4. ábra, Error! Reference source not found.. táblázat).

${ }^{39}$ Megtalálható a 3. melléklet-ben. Ez az orvosok részére készült; más szakok esetében apró módosítások tapasztalhatók.

${ }^{40}$ Már korábbi tanulmányaim során is foglalkoztam a témával (MA-s szakdolgozat).

${ }^{41}$ Ezen felül olyan szempontok is szerepet játszottak mint a szükös időkeret (elsősorban a válaszadók részéről), így igyekeztem minél rövidebb terjedelmüre szabni.

42 . és 6. kérdés

${ }^{43}$ Kissé meglepő módon a két kérdésre adott válaszok között nem volt nagy az eltérés, illetve nem csak egyirányú volt a kapcsolat (vagyis a gondolattal gyakrabban foglalkozók nagyobb arányban terezik a külföldi munkavállalást), hanem fordított is (gyakran gondolt rá, de mégsem tervezi). Az elemzés kitér rá bővebben.

14. kérdés
} 
a tisztított migrációs potenciál kutatását szolgálta. Ezenfelül rákérdeztem a migráció időzítésére, ami befolyásolja a vándorlás tényleges megvalósulásának esélyét ${ }^{45}$ (Horváth 2003b), illetve a külföldi munkavállalás tervezett időtartamára. ${ }^{46}$

A migrációs potenciált befolyásoló szociodemográfiai tényezők közül a nem, az életkor, családi állapot, a szubjektív anyagi helyzet és a foglalkozás (jelen esetben: a hallgatott szak) hatását vizsgáltam. Mivel egy olyan népességet kutattam, amely bizonyos szempontokból homogén (például iskolázottság), illetve fiatal, ezen kérdések némelyike a szülőkre irányult. ${ }^{47}$

Az egyént körülvevő migráns hálózatok, az adott célországokkal összekötő családi és baráti kapcsolatok fontossága és szerepe a migráció tervezésében, illetve a migrációs kultúra kialakulásában, már régóta központi helyet foglal el a migráció irodalmában (példának okáért: (Kandel \& Massey 2002; Gödri \& Kiss 2009; Sik 2011a; Melegh 2012; Guilmoto \& Sandron 2001; Tilly 2001)). A hallgatók által célterületként megjelölt ország(ok) kapcsán rákérdeztem a migráns kapcsolatok meglétére, típusára, illetve a célszemély (a célországban élő rokon/barát/ismerős) részéről érkező esetleges hívogatásra, amely a toborzás egy formájának tekinthető. ${ }^{48}$

A kulturális tőke is fontos szerepet tölt be a migráció tervezésében, mert - ahogyan már az előző fejezetben kifejtésre került - könnyen szállítható és konvertálható (Sik \& Örkény 2003; Sik 2011b; Butler 1995). Mivel jelen esetben az iskolai végzettség hatása nem releváns - hiszen kizárólag magas iskolai végzettséget (hamarosan) megszerzőkről van szó -, a humán tőke kapcsán az idegennyelv-ismeret szintjének és az idegen nyelvü média fogyasztás hatását kutattam. ${ }^{49}$

Az Örkény-Sik által felállított rendszerben a migrációs potenciál vizsgálatában egy további tényezői csoport a „pszichikai tőke”. Ezen tőkefajtához sorolták többek között a potenciális migráns jövőben való bizakodását, személyes helyzetével való elégedetlenségét, az etnikai feszültségek megtapasztalását (Sik \& Örkény 2003). Általánosságban leginkább a coping potenciál fogalmával írható le, amely magába foglalja többek között az optimizmust, kontrollképességet, reményképességet, társadalmi forrást teremtő (kapcsolatépítő) és mobilizáló képességet. Olyan rendszerként fogható fel, amely az egyén „személyes ellenálló képességét és a

\footnotetext{
${ }^{45}$ Nem matematikai- statisztikai értelemben használva a fogalmat.

${ }^{46}$ Ez utóbbi kérdés (12-es kérdés) egyben lehetőséget nyújtott a szokványosan nem migrációnak minősülő, viszont jelentőségét tekintve nagy horderejü munkavállalási forma: az ingázási szándék vizsgálatára is.

${ }^{47}$ Ilyenek: a megszerzett legmagasabb iskolai végzettség, foglalkozás, szubjektív anyagi helyzet (21-25. kérdések).

48 9-11 kérdések. A migráció elterjedésével a toborzás nem csak intézmények révén történik, hanem a személyes kapcsolatokon -a családi és baráti hálózatokon - keresztül is (Sassen 2007).

49 30. és 31. kérdés.
} 
megküzdés eredményességét” biztosítja (Réthy 2002:9.) A hallgatók jövöképét néhány kijelentéshez való attitüdjükkel vizsgáltam; ${ }^{50}$ elégedettségüket pedig a látogatott képzőintézmény által nyújtott szakmai oktatással és eddigi életükkel, feltételezve, hogy a nagyobb fokú elégedettség inkább a helyben maradás szándékát erősíti (Sik \& Örkény 2003). ${ }^{51}$ Ezen túlmenően a gazdasági javak disztributív igazságosságáról alkotott elképzelésükhöz (Tóth 2012) kapcsolódó méltányosság érzésének hatását is kutattam. Feltételezésem szerint a méltányosság érzése az elégedettséghez hasonlóan müködik, vagyis minél inkább véli valaki úgy, hogy méltánytalanság éri, annál inkább tervezi a migrációt.

Rákérdeztem érzelmi kötődések fontosságára (család, szülőföld, saját nemzet iránt érzett felelősség), amelyek gátolhatják a migrációs tervek kialakulását vagy kivitelezésését. Továbbá a külföldi munkavállalást tervezők különböző motivációkat és külső - többnyire szakmai - feltételeket nevezhettek meg, melyek megváltozásával az otthon maradást választanák inkább. ${ }^{52}$

\subsubsection{Az adatfelvétel nehézségei}

Sok nehézséget okozott az, hogy a MOGYE-n folyó képzésnek nem csak az egyetem épülete, hanem a város különböző pontján valamennyi állami kórház is színtere. Végzős diákokról lévén szó, viszonylag kevés számú előadásuk volt egy nap, különösképpen az orvostan-hallgatóknak, ami szintén megnehezítette az elérhetőségüket. Utolsó éves hallgatókként az államvizsgára készülve és szakdolgozatírással elfoglalva eléggé megszürték, hogy mire használják fel idejüket.

De a legnagyobb akadályt az egyetem legfőbb vezetősége jelentette, aki nem hogy partnernek nem mutatkozott a kutatás kivitelezésében, ${ }^{53}$ hanem még a végzősök alapmegoszlására vonatkozó adatok kiadását is megtagadta a hallgatók jogainak védelmére hivatkozva.

\footnotetext{
${ }^{50} 17$-es kérdés

51 Jóllehet a képzéssel való elégedetlenség migrációs potenciált növelő hatásáról kétségeim voltak. Bővebben: a 8. fejezetben.

52 7-es, 13-as és 16-os kérdés. E két utóbbi kérdés esetében a válaszlehetőségeket a magyarországi és romániai kutatások eredményei (Eke et al. 2009; Maier et al. 2011; Rohova 2011), illetve a már migráltakkal való interjúk ihlették.

53 Köszönet és tisztelet azoknak a magyar professzoroknak, akik megosztották tapasztalataikat, és rendelkezésemre bocsátották korábbi kutatásaik eredményeit, illetve lehetőségeik szerint támogattak a kutatásban.
} 


\subsection{A minta}

\subsubsection{Egészségügyi képzés és a képzésben résztvevö csoportok Romániában. A MOGYE} esete.

Erdélyben egyetlen orvosi egyetemen történik magyar nyelvű képzés, ami azt jelenti, hogy az előadások magyarul, a gyakorlati órák pedig román nyelven folynak. ${ }^{54} \mathrm{~A}$ Marosvásárhelyi Orvosi és Gyógyszerészeti Egyetem megalakulása 1872-ra vezethető vissza, ám mint önálló magyar nyelvü intézmény 1948-ban jött létre, és mint az Orvostudományi és Gyógyszerészeti Felsőoktatási Intézet müködött. 1962-ben kéttannyelvü intézetté alakították, ami a magyar szak fokozatos csökkenését eredményezte. A magyar hallgatók aránya az 1984/85-ös tanévtől kezdve kevesebb, mint felére csökkent és 1989-ben alig több mint tucatnyi hallgatót vettek fel a magyar tagozatra (Nagy 2005). 1990-ben megalakult az egységes orvosképzés, ami az általános orvosi és a gyermekorvosi kar összevonásával járt. A rendszerváltást követően a trend megfordult, és ma már - a magyar nyelvü oktatást is nyújtó fő szakok esetében - közel fele a magyar diákok aránya. Az intézmény egyetemi rangját 1991-ben nyerte el (Ábrám 2011; Nagy 2005).

\subsubsection{A vizsgálati csoport}

Kutatásomhoz az alapsokaságot tehát a Marosvásárhelyi Orvosi és Gyógyszerészeti Egyetem (MOGYE) alapszakjain - úgymint általános orvos, fogorvos, gyógyszerész és nővér - tanuló, végzős hallgatók képezték. Kétségkívül más erdélyi orvosi egyetemeknek is vannak magyar hallgatói, de Magyarország számára a fó orvoskibocsátó intézmény a MOGYE, másfelől a szükös erőforrások miatt a kolozsvári és a nagyváradi orvosi egyetem kimaradt a kutatásból. Mivel az egyetem nővérképzése viszonylag kevés számú hallgatóval müködik (30-35 fö/ évfolyam/ nyelvi tagozat), másfelől Erdély több főiskolája is nyújt magyar nyelvü nővérképzést, ezért a nővéri almintát két másik intézmény végzős hallgatóival egészítettem ki. Egyikük a marosvásárhelyi Bod Péter Asszisztensképző Főiskola, amelyet 2000-ben alapítottak, és általában 30-35 fó végez évfolyamonként. A másik a csíkszeredai Louis Pasteur Egészségügyi Posztlíceum, amelyet ugyancsak az ezredfordulón alapítottak, viszont a képzés itt nagyobb létszámban történik (45-50 fö/évfolyam). Bár valamennyi intézmény vonzáskörzete nagy, az egyetem által nyújtott nővérképzés elsősorban a tanulmányi idő

\footnotetext{
${ }^{54} \mathrm{Ez}$ is csak az alapszakokra áll, mármint az orvosi, fogorvosi, gyógyszerész, nővér (egészségügyi asszisztens) és szülésznő szakra. A fogászati asszisztens, balneológia és dietetika szakon az oktatás nyelve román (Ábrám 2011). Ez utóbbiak viszont a kutatásban nem érintettek.
} 
hosszában tér el a főiskolai képzéstől: az előbbi esetében 4 éves, ${ }^{55}$ ez utóbbi esetében pedig 3 éves a képzés. Az orvosi karok esetében 6 éves, a gyógyszerészhallgatók számára pedig 5 éves a képzés időtartama.

A magyar tannyelvü végzős hallgatók esetében a teljes népesség lekérdezésére törekedtem. A kérdőíves adatfelvétel 2012. novemberében zajlott, amikor önkitöltős kérdőívvel kerestem meg a hallgatókat. Jóllehet kötelező előadások kezdete előtt vagy végeztével $^{56}$ próbáltam elérni őket az egyetemi és kórházi előadótermekben, az előadások látogatottsága nagymértékben befolyásolta a válaszadási arányt (a válaszmegtagadók aránya elhanyagolható volt ${ }^{57}$ ). 2013. januárjában történt még egy adatfelvételi kísérlet, ${ }^{58}$ amikor további 26 orvostan- és 3 fogorvos hallgató válaszolt. Így a MOGYE-n a válaszadási arány 73 százalék, a Bod Péter Asszisztensképző Főiskolán 58 százalék, a Louis Pasteur Egészségügyi Posztlíceumban pedig 85 százalék. Az alábbi táblázat tartalmazza a további megoszlásokat. ${ }^{59}$

1. táblázat: Az alapsokaság és a „mintába” került vizsgálati csoport megoszlása intézmény szak és nem szerint

\begin{tabular}{|c|c|c|c|c|c|c|}
\hline \multirow[b]{2}{*}{ Intézmény } & \multirow[b]{2}{*}{ Szak } & \multirow[b]{2}{*}{ Neme } & \multicolumn{2}{|c|}{ Alapsokaság } & \multicolumn{2}{|c|}{ Minta } \\
\hline & & & $N$ & $\%$ & $N$ & $\%$ \\
\hline \multirow[t]{13}{*}{ MOGYE } & $\begin{array}{l}\text { Általános } \\
\text { orvos }\end{array}$ & Férfi & 51 & 37 & 35 & 35 \\
\hline & & Nő & 87 & 63 & 66 & 65 \\
\hline & & Összesen & 138 & 100 & 101 & 100 \\
\hline & Fogorvos & Férfi & 9 & 20 & 6 & 18 \\
\hline & & Nő & 37 & 80 & 28 & 82 \\
\hline & & Összesen & 46 & 100 & 34 & 100 \\
\hline & Gyógyszerész & Férfi & 7 & 14 & 4 & 11 \\
\hline & & Nő & 44 & 86 & 33 & 89 \\
\hline & & Összesen & 51 & 100 & 37 & 100 \\
\hline & Nővér/ápoló & Férfi & 4 & 13 & 2 & 10 \\
\hline & & Nő & 27 & 87 & 19 & 90 \\
\hline & & Összesen & 31 & 100 & 21 & 100 \\
\hline & Egyi & & 266 & 77 & 193 & 77 \\
\hline
\end{tabular}

\footnotetext{
${ }^{55}$ Itt is csak néhány éve, 2010-ben hosszabbították meg a képzés időtartamát 3-ról 4 évre (MOGYE).

${ }^{56}$ Az előadások kezdete előtt sokkal hatékonyabbnak bizonyult, mert a diákok inkább hajlandóak voltak elöadás elött/ alatt kitölteni a kérdőívet, mint az óra végeztével ottmaradni, feláldozva a szabadidejük kis részét, vagy azért, mert vándorolniuk kellett egy másik intézménybe.

${ }^{57}$ A Bod Péter Asszisztensképző Főiskola, illetve a MOGYE román tagozatos nővér hallgatói kivételével, akiknek számottevő része nem volt hajlandó kitölteni a kérdöívet.

${ }^{58}$ A küszöbön levő vizsgaidőszak fokozni látszott a MOGYE hallgatók óralátogatási arányát. A nővérek esetében egyfelől nem volt szükség a második adatfelvételi hullámra (MOGYE és a Louis Pasteur Egészségügyi Főiskola esetében), másfelől nem volt megvalósítható (a Bod Péter Asszisztensképző Főiskola végzősei több hetes kórházi gyakorlaton vettek részt, szétszórva különböző osztályokon).

${ }^{59}$ A MOGYE hallgatói létszáma valójában több 12 fővel, de a teljes populációból kihagytam azokat, akik magyar állampolgárként, magyarországi állandó bejelentett lakcímmel jelentkeztek a képzésre, mivel ők ellenirányú vándorlást végeztek; valószínüleg az alacsonyabb romániai tandíjak jelentették a vonzerőt. (Néhány esetben ugyan egyfajta visszavándorlásról beszélhetünk, mert olyannal is találkoztam, akinek születési helye Románia). Az ilyen hallgatók az általános és fogorvosi szakon lelhetők fel.
} 


\begin{tabular}{|c|c|c|c|c|c|c|}
\hline \multirow[t]{3}{*}{ Bod Péter A.F. } & Nővér/ápoló & Férfi & 2 & 6 & 1 & 6 \\
\hline & & Nö & 29 & 94 & 16 & 94 \\
\hline & & Összesen & 31 & 100 & 17 & 100 \\
\hline \multirow{6}{*}{$\begin{array}{l}\text { Louis Pasteur } \\
\text { E.F. }\end{array}$} & Egy & & & 9 & & 7 \\
\hline & Nővér/ápoló & Férfi & 7 & 16 & 6 & 15 \\
\hline & & Nő & 41 & 84 & 35 & 85 \\
\hline & & Összesen & 48 & 100 & 41 & 100 \\
\hline & $E g y$ & & & 14 & & 16 \\
\hline & Mindösszese & & 345 & 100 & 251 & 100 \\
\hline
\end{tabular}

Forrás: Képzőintézmények nyilvántartásai

A férfiak és az idősebbek kissé alulreprezentáltak a mintában, ezért szakonként nemek és korcsoport szerint súlyoztam (lásd: 1. melléklet). A fent említett két csoport alulreprezentáltsága alacsonyabb óralátogatási arányuk eredménye, amit valószínüleg az okozhat, hogy az idősebbek már munkahellyel/ családdal rendelkeznek, ami korlátozza időbeosztásukat. Ésszerünek tünik, hogy az életkor és a szak között összefüggés áll fenn, tehát minél rövidebb egy szak képzési ideje, annál kisebb a hallgatók átlagéletkora, mégis megmaradtam az azonos korcsoportok használatánál minden szak esetében, mivel a csíkszeredai intézményben - kivételesen - nagyon nagy a kor szórása, így magas az átlagéletkor is, míg a másik két intézményben a nővéri csoport elég homogén korszerkezetü - néhány tag kivételével, akik viszont több évvel eltérnek az átlagtól. Aránytalannak bizonyul a két életkori csoport szerinti felosztás a fiatalabbak javára, viszont a 24 éves kor a leggyakoribb a legtöbb szak esetében, így ha ezeket nem a fiatalabb korcsoporthoz, hanem az idősebbekhez sorolom, akkor ez utóbbi lesz aránytalanul nagy. Szerepet játszott a korcsoportok meghatározásánál továbbá, hogy ne a hallgatott szakot tükrözzék csupán le, illetve nem utolsósorban az is, hogy a kontrollmintából hiányoznak a nővérek, akik viszont a vizsgálati csoportot leginkább fiatalítják, így jóformán csak néhány román hallgató lenne a fialatabb korcsoportban.

\subsubsection{Kontrollcsoport}

Összehasonlításként a román tannyelvű szakokon is lekérdeztem a kérdőívet, itt viszont sokkal alacsonyabb volt a válaszadási arány, ami elsősorban annak tulajdonítható, hogy tapasztalatom szerint a külön, román nyelven tartott előadások látogatottsága jóval alacsonyabb, mint a magyar hallgatók esetében. ${ }^{60}$ Az általános orvostan-, fogorvos és gyógyszerész szakos, román nyelven tanuló 236 végzősből mindössze 75 diák töltötte ki a kérdőívet, ami 32 százalékos válaszadási arányt jelent. Ebből kifolyólag nem

${ }^{60}$ Amint említettem már, a teljes népesség lekérdezésére törekedtem. Azt sajnos nem sikerült kiderítenem, hogy mi állhat az alacsonyabb óralátogatási arány hátterében (talán az óraadó kevésbé követeli meg a jelenlétet; más a hallgatók és tanárok attitüdje?). 
tekintehető reprezentatívnak. További torzítás forrása lehet az, hogy magyar vagy vegyes etnikumú házasságból származó hallgatók a román tannyelvü csoportba jelentkeznek, feltételezésem szerint a szaknyelv jobb elsajátítása és a későbbiekben való jobb boldogulás reményében. A 75 hallgatóból 4 említette meg a beszélt nyelvek között a magyart, mint amelyet folyékonyan beszél. Mivel a magyar és a román nyelvű kérdőív kis mértékben ugyan, de különbözött egymástól (a kisebbséget érintő kérdéseket nem tartalmazta a román nyelvü kérdőív), ezeket a válaszadókat a román tannyelvü mintában hagytam. Egy másik érv ezen kategorizálás mellett a már eleve adott „önbesorolás”, nyelvi azonosulás: valamilyen oknál fogva a román tagozatra jelentkezett. További problémát jelentett az, hogy nem ismert előttem ezen hallgatók aránya a román tagozaton, és joggal feltételezhető, hogy ennél a négy hallgatónál többről van szó, vagyis a tényleges román alapnépesség számának pontos ismerete hiányában megmaradtam a tagozatonkénti magyar-román besorolásnál, bár a román megnevezést idézőjelesen kell érteni, még ha nem is mindig történik utalás erre. A kontrollmintában szerepel 47 (a 141-ből) általános orvostan-, 11 (az 54-ből) fogorvostan és 17 (a 41-ből) gyógyszerészhallgató. ${ }^{61}$ A nővérek közül mindössze 5 hallgató vállalkozott a kérdőív kitöltésére a 34-ből, akikből három - mint utólag kiderült - magyar volt. Ezért az asszisztenseket teljesen kihagytam az összehasonlító elemzésből, amely összehasonlítással egy különálló fejezet foglalkozik.

\subsection{Interjúk. Alanyok és módszerek}

Az interjúzás két lépcsőben történt, két különböző célcsoportban. Az egyikre - részben - a survey kutatást megelőzően, a másik pedig azt követően került sor.

\subsubsection{Migránsok}

Először az Erdélyből már átvándoroltakat, tehát a Magyarországon élő orvosokat és nővéreket kerestem meg hólabda módszerrel. Mivel nem állt módomban kérdőíves felmérést végezni körükben, - hiszen nincs egy nyilvántartás, amelyből kiderülne, hogy földrajzilag hol találhatók, hogyan oszlanak meg -, ezért döntöttem a kvalitatív módszer mellett. És mivel az említett nyilvántartás hiányában nem állt rendelkezésemre egy mintavételi keret, ezért fordultam a hólabda módszerhez.

${ }^{61}$ Az alkalmazott súlyokat a 2. melléklet tartalmazza. 


\subsubsection{A hólabda módszer}

Egy olyan mintavételi eljárás, amely a nem valószínűségi kiválasztási módszerek körébe tartozik. Általában feltáró jellegü kutatások esetében alkalmazandó, amikor a vizsgált népesség tagjainak körülhatárolása különböző nehézségekbe ütközik (Babbie 2003). Az egyik interjúalanytól a másikig való eljutás módszere semmiképpen sem tekinthető statisztikailag reprezentatívnak (Bryman 2008). A hólabda eljárással történő kiválasztásnak egyik nagy veszélye, hogy csak egy összefüggő hálózatba tartozó egyéneket fog be, így a kutató nem szerez információkat azoktól/azokról, akik ezen a körön kívül vannak (hogyan, miben különböznek). Statisztikai szempontból tehát egy nem megbízható módszer, viszont a vizsgálni kívánt migrációs motivációk és döntési mechanizmusok feltárására alkalmas.

Összesen 14 áttelepült egészségügyi dolgozóval készítettem interjút, ${ }^{62}$ akik 2002 és 2007 közötti időszakban vándoroltak Magyarországra. ${ }^{63}$ A 14 interjúalanyból 10 nő volt; szakok szerint: 10 szakorvos (egyikük elhagyta a közvetlen szakterületét és jelenleg a gyógyszeriparban dolgozik), 2 fogorvos és 2 nővér; intézmények szerint: 9 a MOGYE-n, 3 a nagyváradi orvosi egyetemen és ketten egyik székelyföldi asszisztensképzőben szereztek diplomát, származás szerint: 8 fő a Székelyföldről, 4 Közép Erdélyből (Marosvásárhely és környéke) és 4 fö a Partiumból vándorolt az anyaországba. ${ }^{64}$ Korukat tekintve a 30-as éveik első felében jártak (31-35 éves), egyetlen kivétellel, aki már belépett a 40-es éveibe, amely tény elörevetíti azt, hogy közvetlenül a diplomázást követően vagy röviddel azután migráltak. Az adatfelvétel 2012. ősze- 2013. tavasza közötti időszakban zajlott. A kezdeti fázisban fél-strukturált interjúkat készítettem (3 db), majd váltás történt, mivel módszertani szempontból megfelelőbbnek tűnt a narratív-félig strukturált interjú $(11 \mathrm{db})$. Ez azt jelenti, hogy narratív kérdéssel indítottam, majd rákérdeztem bizonyos eseményekre/témákra, - ha az interjúalany nem említette a narratívája során -, amelyek az interjúvezetőben szerepeltek. A narratív kérdéssel való indítás célja az volt, hogy a válaszadót minél kevésbé befolyásolja válasza megfogalmazásában, és lehetősége legyen olyan narratíva illetve identitás bemutatására, amelyet valószínűleg korlátoztak vagy irányítottak volna a kérdések mögött meghúzódó domináns ideológiák. ${ }^{65}$ A kutatásnak ez a szakasza

\footnotetext{
${ }^{62}$ Ebből 10 személyes beszélgetés volt, 4 pedig Skype-on keresztüli (ez utóbbi csoportba azok tartoznak, akik nem Budapesten praktizálnak).

${ }^{63}$ Ez többnyire a második nagy orvos-bevándorlási hullám időszakát öleli fel, így nagyobb is volt az esélye annak, hogy az ebben az időszakban vándorolt emberekre találok. Ugyanakkor a hólabda módszer hátrányként említett „becsatornázási” jelenség is egyben.

${ }^{64}$ A MOGYE egész Erdélyre kiterjedő vonzereje itt is bizonyítást nyer, mert nem csak Közép Erdélyből és a Székelyföldről, hanem a Partiumból is vonz hallgatókat.

${ }^{65}$ A narratív módszerről lásd bővebben: (Kovács \& Melegh 2001).
} 
egyfajta kvalitatív előkészítésként szolgált a migrációs potenciál vizsgálatához, a külföldi munkát vállalni szándékozók elemzéséhez.

\subsubsection{Végzös hallgatók; potenciális migránsok}

A végzősök körében a kérdőív lekérdezését követően félig strukturált interjúkat is készítettem a döntésben szerepet játszó tényezők, mechanizmusok és stratégiák jobb, teljesebb megismerésére törekedve - a trianguláció elvét követve. A mintavételben a szakok és társadalmi státus szerinti megoszlást követtem. A családi társadalmi státus két változóból, mégpedig a szülők iskolai végzettségéből és foglalkozásából képzett index, mely alapján 3 kategóriát különböztettem meg: magasabb (magas iskolai végzettséggel párosuló diplomás, szellemi, vállalkozói, vagy vezetői munkakör), alacsonyabb (alacsonyabb szülői iskolai végzettség és azzal párosuló- kék galléros, gazdálkodó, inaktív- munka, beosztás) és vegyes (egyik szülő egyik, a másik szülő a másik kategóriába tartozik) ${ }^{66}$ státus.

A szükös időkeret miatt ${ }^{67}$ szakonként 2-2 hallgatóval szándékoztam elbeszélgetni: egy alacsonyabb és egy magasabb státusú családból származóval. Ez összesen a 4 szakon és a 2 tagozaton (magyar és román) 16 diákot jelent. A megvalósult minta összesen 20 főből áll, mivel nem minden csoportnál sikerült kontaktembert találni, aki segíthetett volna az előzetes kiválasztásban, így némely csoport esetében több végzőssel is készítettem interjút, mire meglett a megfelelő összetétel. Sajnos a státus szerinti kiválasztást nem sikerült érvényre juttatni a nővérek esetében - sem a magyar, sem a román tannyelvü csoportban -, ahol csak alacsonyabb státusú hallgatókkal tudtam beszélgetni; illetve a magyar fogorvosok csoportjából csak magas státusúakat sikerült találnom. Viszont a nővérek esetében a kérdőíves felmérés eredményei alá is támasztják, hogy túlnyomó többségben az alacsonyabb státusú szülők gyermekei választják ezt a szakmát, ${ }^{68}$ valamint azt is, hogy a magyar nyelvű fogorvos-hallgatók körében a legmagasabb azoknak aránya, akik magasabb státusú családból származnak. A 20 interjúalany összetétele a következő: 3 magyar és 2 román orvostanhallgató, 2 magyar és 3 román fogorvosi, 3 magyar és 3 román gyógyszerészhallgató, és 2 magyar 2 román nővér. Az interjúk 2013. áprilisában készültek.

A végzősökkel készített fél-strukturált interjúk elemzése nyílt és strukturális kódolás ötvözésével történt. A nyílt kódolás vagy kezdő kódolás (initial coding) a

\footnotetext{
${ }^{66}$ Kisebb arányban, de természetesen olyan esetek is előfordultak, amikor egyik vagy mindkét szülő felfelé vagy lefelé volt mobil (diszkrepancia volt az iskolai végzettsége és foglalkozása között). Ilyen esetekben a foglalkozás szerint történt a besorolás.

${ }^{67}$ Mind a magam, mind a végzős hallgatók részéről fennálló probléma volt.

${ }^{68}$ Ezt a szakirodalom is alátámasztja, és a szakma alacsonyabb presztízsével magyarázza (Freidson 1970).
} 
szöveg kisebb egységekre tördelése révén az interjúk közötti hasonlóságok és különbségek megtalálását segítette. A strukturális kódolás pedig a rendszerezést szolgálta, mely a kérdőívből származó eredményekkel való összevethetőséget alapozta meg. ${ }^{69}$ Mindezt nagy mértékben megkönnyítette az interjú típusa, mert az interjúvezetőben szereplő kérdések alapján egyszerüvé vált a rendszerezés. Ezt a két módszert egészítették ki második lépésben az identitás kódjai, amelyeket az határozott meg, hogy az egyén hogyan helyezte el magát a történetben - pontosabban: válaszaiban -, érvelésében másokhoz és az eseményekhez képest (Riessman 2012). A kódok segítségével végül fürtelemzést végeztem, ${ }^{70}$ amelynek célja a különböző típusok feltárása volt (lásd a 9. mellékletet).

\subsection{A kutatás korlátai}

A kutatás a jövőbeli erdélyi magyar egészségügyi szakemberek migrációs potenciálját vizsgálta, de kérdéses, hogy a kapott eredmények mennyiben általánosíthatók egész Erdélyre. Nem megállapítható az, hogy miben különböznek a vizsgált diákoktól azok a magyar anyanyelvü orvos- és gyógyszerészhallgatók, akik a román nyelvü oktatás mellett döntenek - talán az intézmény földrajzi közelsége miatt.

Másik problémaforrás lehet a nővérképző intézmények kiválasztásából származó torzítás, hiszen, magyar nyelvü nővérképzés több más városban is folyik, illetve nincs semmilyen adat arra nézve, hogy hány magyar asszisztens végez román tannyelvü intézményben vagy csoportban. Az idősebb és az előadásokról hiányzó hallgatók nagyobb arányban maradtak ki a mintából, mint fiatalabb évfolyamtársaik, pedig ezek a tényezők szignifikáns különbségeket rejthetnek magukban.

A mintavételnél egy további fontos problémát jelent az, hogy a kontrollminta nem reprezentatív. Így a magyar és a román tannyelvű mintát összehasonlító elemzések eredményeit nagyon óvatosan kell kezelni.

Számításba kell venni továbbá a kérdőív román nyelvre fordításából adódó esetleges torzításokat is.

A kutatás egy további hiányossága, hogy a kérdőív lekérdezése időben részben átfedte a már kivándoroltakkal való interjúk készítését. Így a narratív interjúk melyeknek survey előkészítő szerepük is volt - némely fontos eredménye nem került bele a kérdőívbe: mint pl. a külföldi szakmai tanulmányútnak/ nyári gyakorlatnak a

\footnotetext{
${ }^{69}$ A módszerek részletesebb leírásához lásd: (Saldana 2009).

${ }^{70}$ A módszerről bővebben lásd: (Kovács \& Melegh 2001).
} 
migrációs tervekre gyakorolt hatása; a migráns hálózatok, illetve családi- és párkapcsolatok fontossága motivációkként (a motivációk rangsorában).

A már Magyarországon élö, Erdélyből bevándorolt egészségügyi dolgozók hólabda módszerrel történő kiválasztása nagyon esetleges és viszonylag szük időterjedelemben átvándoroltakat fed le, ezért nem vonható le messzemenő következtetés ezekből az interjúkból. Müködhetnek az itt leírtakon túl eltérő mechanizmusok is, amiket nem sikerült feltárni. Ennek a módszernek egy további hátránya, hogy mivel egyik interjúalany egyeztetett az interjú ügyében a másikkal (akinek tudta és beleegyezése nélkül nem akarta kiszolgálatatni az elérhetőségét), nem tudni, hogy a kutatásról közölt információk (gondolok itt például a feltett kérdések említésére) hogyan befolyásolták a későbbi válaszadókat.

Triviális, de maga az a dolog, hogy az egyének tudják, hogy megfigyelik őket, kiválthatja az általuk elképzelt elvárásoknak való megfelelési kényszert. ${ }^{71}$

A kutatás egy további korlátja, hogy csak az Erdélyben diplomát szerzett és szerző egészségügyi dolgozókkal foglalkozik, és nem terjed ki az egyetemi tanulmányaik alatt Magyarországra vándorlókkal, akik esetében valószínüleg más mechanizmusok is müködnek, mint a vizsgált népességben. Továbbá az eredmények alapján nem adható válasz arra a kérdésre, hogy a magyar egészségügyi rendszerben levő munkaerő- hiány pótlását (szakterületenként, földrajzi régiónként) vagy inkább az egyenlőtlenségének növelését eredményezné a tervezett migráció megvalósulása.

${ }^{71}$ Az egyik interjúalany például megjegyezte, hogy ő nem megfelelő a válaszadói szerepre, mert nem tervez külföldre vándorolni. 


\section{EGÉSZSÉGÜGYI DOLGOZÓK A MIGRÁCIÓS TÉRBEN}

Magyarországon is évek óta egyre fokozódó problémát jelent az egészségügyi személyzet elégtelensége. Ennek fő okai: a szakma rossz presztízse, ami az alacsony beiskolázási számokban ölt testet; illetve a szakszemélyzet elvándorlása, melyet a hazai bérezéssel, továbbképzési lehetőségekkel, szakmai lehetőségekkel és az életminőséggel való elégedetlenség generál (Baukó et al. 2003; Vízvári 2003). A Magyar Kórházszövetség adatai alapján 2002-ben a kórházak esetében a betöltetlen állások száma meghaladta a 8000-et, amiből 2393 orvosi, 1197 asszisztensi és 2123 ápolói állás volt (Baukó et al. 2003). A magyarországi orvosok elvándorlását 2003-tól elemzik a Semmelweis Egyetem Egészségügyi Menedzserképző Központ munkatársai. Egy 2008ban végzett elemzésükből kiderül, hogy a magyar rezidens orvosoknak közel kétharmada (65\%) tervezett külföldi munkavállalást, ${ }^{72}$ ám a hiányszakmák esetében (pl. aneszteziológus, radiológus, sebész, háziorvos) még magasabb ez az arány. A migrációt tervezők körében a legfontosabb motivációk között a magasabb bérek, a jobb szakmai lehetőségek és munkakörülmények szerepeltek (Eke et al. 2009).

A magyar egészségügyben az orvoshiányt a korábbi, rendszerváltást megelőző időben is többnyire a határon túli magyar szakemberek pótolták. A bevándorolt orvosok többsége romániai, ukrajnai és jugoszláviai egyetemeken szerezte szakképesítését. 1990-ben a magyar állampolgárságot szerzettek 10,6 százaléka az egészségügy területén dolgozott, és jóllehet arányuk a kezdeti csúcs után csökkenő tendenciát mutat, 1992-ben is megközelítette a 10 százalékot (Tóth 1994). 1991 első félévében munkavállalási engedélyt szerzett 19121 román állampolgárnak 9 százaléka volt egészségügyi dolgozó (Hárs 1992b). 1989- 1992 közötti időszakban a MOK (Magyar Orvosi Kamara) 1462 bevándorolt orvost regisztrált, amelynek 61 százaléka (887 fö) Marosvásárhelyen szerezte diplomáját (Balázs 2003). A Marosvásárhelyi Orvosi és Gyógyszerészeti Egyetem (továbbiakban MOGYE) az ezredfordulót követő években is kulcsfontosságú szerepet töltött be az anyaországban fellépő orvoshiány utánpótlásban: a 2005-ben

\footnotetext{
${ }^{72}$ A rezidens orvosok más kategória, mint a vizsgált hallgatók, hiszen már diplomázott, szakképzésüket elkezdett fiatalokat foglal magába. Ez egyfelől azt jelenti, hogy köztük vannak a MOGYE bizonyos végzettjei, akik Magyarországon kívánnak szakképesítést szerezni. Másfelöl ez állhat az anyaországiakra is: vagyis már elvándoroltak közülük azok, aki fejlettebb országban kívánnak szakorvosi címet nyerni. Így a két szelekciós mechanizmus talán kiegyenlíti egymást Magyarország szempontjából. Tehát magas ez a migrációs szándékot jelző arányszám, tekintetbe véve azt is, hogy a migrációt komolyan tervezők egy része valószínüleg már kilépett ebből a csoportból.
} 
honosított 190 oklevél fele (95) marosvásárhelyi volt (Ábrám 2011).

A szakdolgozókat illetően, Balogh Zoltán, a MESZK (Magyar Egészségügyi Szakdolgozói Kamara) elnöke közlései szerint, az új évezred kezdetén, Románia uniós csatlakozását megelőző években kb. 200-250 ápoló vándorolt Magyarországra évente. Ez alapvetően hiánypótló szerepet játszott a magyar egészségügyben, ahol az ápolói létszámcsökkenés már megkezdődött. Megfigyelhető viszont a határon túli magyarlakta területekről érkező egészségügyi szakdolgozók számának csökkenése. Ennek ellenére 2007-ben még mindig Románia volt a legfontosabb kibocsátó ország - a legtöbb migráns innen érkezett - Magyarország számára, de ez már csak alig 50 fö́t jelentett, 2008-ban pedig ennél is kevesebbet (Balogh 2009). A MESZK egy kutatása szerint ${ }^{73}$ a munkaerő-hiányt tovább súlyosbítja a határon túlról érkezett migránsok visszavándorlása, amely 2008-ban 12 százalékos létszámcsökkenést jelentett a külföldi munkavállalók körében a vizsgált intézményekben. A visszavándorlás mellett a továbbvándorlás, illetve ,viszont-toborzás” jelensége is megfigyelhető (Balogh 2009). ${ }^{74}$

Románia vezetőségét az országnak 2007-ben megvalósult Európai Unióhoz való csatlakozását megelőzően az egészségügyi alkalmazottak migrációját tekintve egy ambivalens hozzáállás jellemezte: ${ }^{75}$ egyfelől a román egészségügyi rendszer szakemberhiányát kommunikálta, és javaslatokat fogalmazott meg az orvosokat otthon tartására. ${ }^{76}$ Másfelől az állam maga toborzó alanyként is tevékenykedett: a 2001-ben létrehozott Munkaerő- Migrációs Hivatalon (OMFM- Oficiul pentru Migraţia Forţei de Muncă) keresztül, amely ügynökség végezte a különböző foglalkozású szakemberek - köztük az orvosok, nővérek és ápolók - toborzását, folyamatosan tájékoztatva az érdeklődőket a különböző országokban felmerülő keresletről, hiányszakmákról, a bérekről, munkaügyi törvényekről, a munkavállaláshoz szükséges dokumentumokról. A Hivatal nemcsak munkaerö-közvetítőként müködött, hanem esetenként a munkaadó és munkavállaló közötti szerződés megkötésében vállalta a lebonyolító szerepét is (Baldwin-Edwards 2008).

\footnotetext{
73 Elektronikus kérdőívben kérdezték meg 13 kórházi intézmény (3 fövárosi és 10 vidéki) ápolási vezetőjét.

${ }^{74}$ A MESZK elnökével 2013. júliusában készített interjúmban arról számolt be a professzor úr, hogy a Romániát határoló megyékben megjelent az ingázós munkavállalási forma, amikor a magyarországi szakdolgozók vállalnak munkát egy-egy közeli erdélyi nagyvárosban. Öket a visszavándorolt dolgozók „vitték magukkal”. Az elnök becslése és tapasztalatai szerint az erdélyiek továbbvándorlása elsősorban a 35-40 év közötti korcsoportra jellemző és az elvándorlók 10-20 százalékát teszik ki. Erre egyrészt az igazolást igénylők születési helyéből (nem magyarországi születésü), másrészt a célországból következtet (pl. Franciaországba vagy Belgiumba inkább a román nyelvet beszélők szándékoznak menni).

${ }^{75}$ A migráció egy kihívás elé állítja az államot: a gazdasági tendenciák a nyitott cserét igénylik, az állampolgárság viszont a területi és közösségi védelmet (Faist 2000).

${ }^{76}$ A 2005 -ös országos választásokat követően Eugen Nicolaescu miniszter egy interjúban arról számolt be, hogy tervezett reformjaikkal, melyek a rendszer átszervezését, az orvosi bérek növelését, munkakörülményeik javítását, az orvosokat megbecsülő bánásmódot tűzték ki célul, a kivándorlók számának csökkentését remélik elérni (Ion 2006).
} 
Ebben az időszakban Románia több országgal is kétoldalú megállapodást kötött (mint Németország, Spanyolország, Magyarország, Svájc, Luxemburg, Franciaország), amelyben bizonyos szakmákban - köztük az orvosi is - munkát vállalhattak a román állampolgárok (Macovei 2004; Cehan \& Teodorescu 2012). Az EU-s csatlakozás magával hozta az orvosi oklevelek kölcsönös elismerését, aminek következtében megnövekedett az orvosok külföldi munkavállalási hajlandósága (Rohova 2011). A Román Munkaerő- Migrációs Hivatal 2005-ös év végi beszámolójából kiderül, hogy a román Egészségügyi Minisztérium- Humán Erőforrás és Szakmai Fejlődés Igazgatósága által szolgáltatott adatok szerint 360 orvos és 1700 asszisztens hagyta el munkahelyét Romániában 2005. január- augusztus közötti időszak alatt külföldi munkavállalás céljából. ${ }^{77}$ A fó célországok Németország, Svájc, Anglia, Olaszország és Magyarország. A Német Orvosok Föderációs Kamarája adatai szerint 660 romániai orvos volt Németországban 2004-ben. Olaszországban az Orvosi Kamara nyilvántartásában 2004 végén 94 romániai orvos szerepelt, közülük 20 fogorvos.

Az EU-s csatlakozás tehát megteremtette az egészségügyi képesítések szállíthatóságának feltételeit, vagyis elősegítette az orvosi, nővér, fogorvosi, szülésznő és gyógyszerész diplomák kölcsönös, és legtöbb esetben automatikus elismerését. Jóllehet több EU-15 ország ideiglenes korlátozásokat állított fel Romániával szemben az átmeneti időszakra, az egészségügyi dolgozók elég rövid időn belül élhettek a szakma privilégiumaival, mivel a minősítések elismertetése egy automatikus eljárás révén történik, mely során az egyéni képesítést a képzettségi szinttel és a képzés idejével ellenőrzik, és nem a szaktudás egyéni felbecsülésével vagy a kért kompetenciák mérésével (Wismar et al. 2011).

Az újonnan csatlakozott országok alacsonyabb bérezési szintje nagyon erős ösztönzők voltak abban, hogy munkaerejük máshol keressen állást (Maier et al. 2011). Mindezek hatása látható a magas migrációs potenciál (más tagországokhoz viszonyítva) és a külföldön munkavállalás céljából regisztrált orvosok és nővérek számában. Romániában a csatlakozás évében 4990 fó igényelte a külföldi munkavállaláshoz szükséges igazolást, amely az egészségügyi dolgozók 10 százalékát teszi ki, és 2008. januármárcius közötti időszakban további 2683 fö. Jóllehet empirikus kutatás igazolta, hogy 2007-ben a 4990 dolgozóból 1421 (a teljes egészségügyi munkaerő 3 százaléka) volt, aki ténylegesen migrált, ez még mindig magas arány ahhoz képest, hogy több más tagállamban maga a migrációs potenciál - a megigényelt igazolások számával becsülve

\footnotetext{
77 A Munkaerő- Migrációs Hivatal kizárólag a legalább 2 év szakmai gyakorlattal rendelkező orvosokat szerződtette, 1-2 éves időszakra. Tehát a frissen végzettek nem jelentek meg ezekben az adatokban. Lásd Daniela Nicoleta Andreescu szakszervezeti vezető összefoglalóját (Andreescu 2005).
} 
- többnyire 3 százalék alatti volt a csatlakozásuk évében (például Magyarország: 2,7\%; Litvánia: 2,7\%, Észtország: 6,5\%; illetve 2005-ben már 1,8\%) (Maier et al. 2011).

A WHO egy európai szintü, átfogó kutatásának eredményeképpen megállapítja, hogy a megelőző várakozásokkal/ félelmekkel ellentétben, az újabban csatlakozott országok (EU 12) migránsai nem árasztották el a korábbi tagállamokat, és viszont: az utóbbiak részéről sem történt masszív agyelszívás. Az Unió kibővülése felerősített már korábban létező migrációs áramlatokat, de több ország esetében is enyhén csökkenő tendenciát látunk a kezdeti csúcs után. A szervezet viszont elismeri, hogy bár a kiáramlás nem is érte el a várt nagyságrendet, sok ország tekintélyes számú egészségügyi dolgozót veszített el a csatlakozást követő majdnem 10 év folyamán (Wismar et al. 2011). Románia is a magas fokon érintett országok közé tartozik, mely állapotot tovább súlyosbítja az a jelenség, hogy a csatlakozás után néhány évvel később is viszonylag magas a munkaerő migrációs hajlandósága (tehát nem csak a retrospektív adatok hatása tükröződik a kezdeti csúcsban). Ennek magyarázatául valószínüleg az éppen ekkor kezdetét vevő gazdasági válság szolgál. Míg egyes országok (pl. Lengyelország, Szlovákia és Észtország) munkaerő-politikájuk változtatásával és a bérek növelésével igyekeztek maradásra bírni szakdolgozóikat (az intézkedések hatékonyságát jelzik az igazolást igénylők számának csökkenése; ám azt is számításba kell venni, hogy ez hosszú távon nem fenntartható a gazdasági válság feltételei közepette), Romániában a válság miatt éppen ellenkező intézkedések történtek 2010ben: drasztikus bércsökkentés és létszámleépítések, melyek hatása érzékelhető a növekvő migrációs potenciálban, azaz a kikért igazolások számában (Maier et al. 2011; Galan et al. 2011).

A migrációt tervező romániai egészségügyi dolgozók számára a legfontosabb ösztönző tényezők - remélt nyereségek - a külföldön elérhető jóval magasabb bérek (átlagosan négyszeres a különbség (Glinos et al. 2011)), illetve a hazai társadalom részéről tapasztalt alacsony társadalmi megbecsültség és alacsony értékelés/ tisztelet. A bérekkel, a munkafeltételekkel és a társadalmi megbecsültséggel való elégedetlenség egyaránt jellemző a migrációt tervezőkre, illetve a befejezetlen egészségügyi reformok és meg nem valósított célok is egy kiábrándult egészségügyi munkaerőt teremtettek, amely kész elhagyni szülőföldjét. Szerepet játszik még (a Magyarországról távozni készülő dolgozók esetében is) egy külföldi egészségügyi rendszerben szerzett munkatapasztalat (Glinos et al. 2011; Galan et al. 2011; Rohova 2011).

A tükörstatisztikák fényében a romániai migráns egészségügyi dolgozók legfontosabb célterületei Franciaország, Olaszország, Németország és az Egyesült Királyság. 
2. táblázat: Romániai egészségügyi dolgozók Európában: néhány célország statisztikája

\begin{tabular}{|c|c|c|c|}
\hline Ország & Nyilvántartottak száma (stock) & $2007-2008$ & 2009 \\
\hline Belgium & Nővér & 175 & na \\
\hline \multirow[t]{2}{*}{ Franciaország } & Orvos & 1000 & 1160 \\
\hline & Fogorvos & 50 & na \\
\hline \multirow[t]{3}{*}{ Németország } & Orvos & na & 927 \\
\hline & Fogorvos & 157 & na \\
\hline & Nővér és szülésznő & 606 & na \\
\hline \multirow[t]{2}{*}{ Olaszország } & Nővér & 8497 & na \\
\hline & Orvos & na & 555 \\
\hline \multirow[t]{2}{*}{ Ausztria } & Fogorvos & 103 & na \\
\hline & & $2003-2008$ & \\
\hline \multirow[t]{6}{*}{ UK } & Orvos & 671 & \\
\hline & Orvos müködési engedéllyel & 125 & \\
\hline & Nővér és szülésznő & 493 & \\
\hline & Növér müködési engedéllyel & 315 & \\
\hline & Fogorvos müködési engedéllyel & 6 & \\
\hline & $\begin{array}{l}\text { Gyógyszerész müködési } \\
\text { engedéllyel }\end{array}$ & 47 & \\
\hline
\end{tabular}

Forrás: (Wismar et al. 2011)

Ezek az adatok felvetik annak lehetőségét, hogy a román egészségügyi rendszer munkaerő-hiánnyal küzd (ezt igazolandó lásd: 3. ábra); ám nem mutatja meg a migráció intenzitását az ország különböző földrajzi régióin és az egyes szakterületeken belül. Mert a fő problémát az jelenti, hogy egyes régiókban (pl. az orvosokkal és nővérekkel legkevésbé ellátott észak-keleti régió a legnagyobb kibocsátó) és szakterületeken (pl. intenzív terápia, gyerekgyógyászat) nagyon egyenlőtlenül oszlik meg a rendelkezésre álló munkaerő, ${ }^{78}$ és némelyikben olyan mértékű a szakember hiány, hogy néhány fö kivándorlása is már a helyi egészségügyi rendszer fenntarthatóságát veszélyezteti. A gond másik forrása a bemeneti oldalon jelentkezik: az orvosi pálya vonzereje nagyon lecsökkent: míg az ezredfordulón 7-8 hallgató jelentkezett az egyetem által egy meghirdetett helyre, mostanra már csak 0,9 fö jut egy helyre ${ }^{79}$ (Maier et al. 2011). A szakma alacsony státusa - főként a nővéreké - a bérezéssel is megragadható: 2008-ban a nemzetgazdasági tevékenységek sorában a hatodik helyen állt. Az alacsony fizetés az elvándorlás fokozódása mellett a szakmai elégedetlenség növekedését, romló

\footnotetext{
${ }^{78}$ Főként a nagy egyetemi központokban, illetve a gazdaságilag fejlettebb régiók városaiban tömörülnek, míg a falvak súlyos szakemberhiánnyal küszködnek (Rohova 2011).

${ }_{79}$ Az érem másik oldala viszont az, hogy a korábbi keretszámokat is megnövelték.
} 
személyzeti morált és az informális hálapénz követelését eredményezte (Rohova 2011). ${ }^{80}$

A Bukaresti Orvosi és Gyógyszerészeti Egyetem egyik professzorának a nyilatkozata alapján 2010-ben 2779, 2011-ben 2841 orvos váltotta ki a külföldi munkavállaláshoz szükséges okiratot. Legfontosabb célországaik: Németország, NagyBritannia és Franciaország (Román Orvosi Kollégium 2012). Jelentős eltérés tapasztalható a romániai egészségügyi dolgozók és a román migránsok célországai között (ez utóbbiak esetében: Olaszország, Spanyolország, Németország) (Gödri \& Kiss 2009), amely arra enged következtetni, hogy az egészségügyi dolgozók más hálózatok tagjaiként mozognak a migrációs térben. Illetve kedvező fogadtatásuknak köszönhetően a gazdaságilag fejlettebb, magasabb béreket kínáló országok munkaerőpiacaira is beléphetnek (lásd: 2 . ábra és 4 . melléklet).

Az igényelt elismerési igazolások adatainak értelmezésekor óvatosság szükséges, mivel nem azt jelentik, hogy ennyi szakember ténylegesen el is hagyta az országot, viszont jelzik a migrációs szándékot. Az orvos professzor becslése szerint ilyen mértékü elvándorlás esetében az ország éves vesztesége 22 millió euró, mivel egy államilag támogatott képzés keretében végzett orvostan-hallgató 6 éven át tartó taníttatásának a költsége kb. 8000 euró (Viasu 2011). Ezen felül még számításba kell venni a szakdolgozók, főként nővérek elvándorlását és oktatásukból származó anyagi veszteségeket. Sajnálatos módon a nővérek vándorlásáról még kevesebb adat áll rendelkezésre, pedig valószínűleg ők a legnépesebb migráns egészségügyi dolgozói csoport (Glinos et al. 2011).

Jóllehet folyamatosan növekszik az orvosok száma (pl. 2008-ban 50238 volt a számuk, vagyis 100000 lakosra 234 jutott), de ez még mindig alacsony az európai országok rátáihoz képest. Legnagyobb hiány a nővérek és a szakorvosok körében található, amelyet elsősorban az elvándorlásnak tulajdonítható. A nővérrel való ellátottsági ráta nem sokkal haladja meg az EU- átlag felét (Rohova 2011).

Az alábbi ábra Románia és - a kutatás eredményei alapján - a magyar nyelven tanuló potenciális egészségügyi migránsok számára legfontosabb célországok egészségügyi dolgozókkal való ellátottságát mutatja.

\footnotetext{
${ }^{80}$ Az OECD és WHO jelentések fényében az egészségügyi dolgozók nemzetközi migrációja önmagában nem oka a krízises munkaerő-hiánynak, hanem csak ráerősítenek a már létező problémákra, mint a világgazdasági válság, járványok, rosszul müködő egészségügyi rendszerek (Cehan \& Teodorescu 2012). Inkább mélyebben meghúzódó okok tüneteiként javasolják kezelni az elvándorlást (Wuliji et al. 2009).
} 
3. ábra: Az 1000 fóre jutó egészségügyi dolgozók száma négy európai országban 2010ben $^{81}$

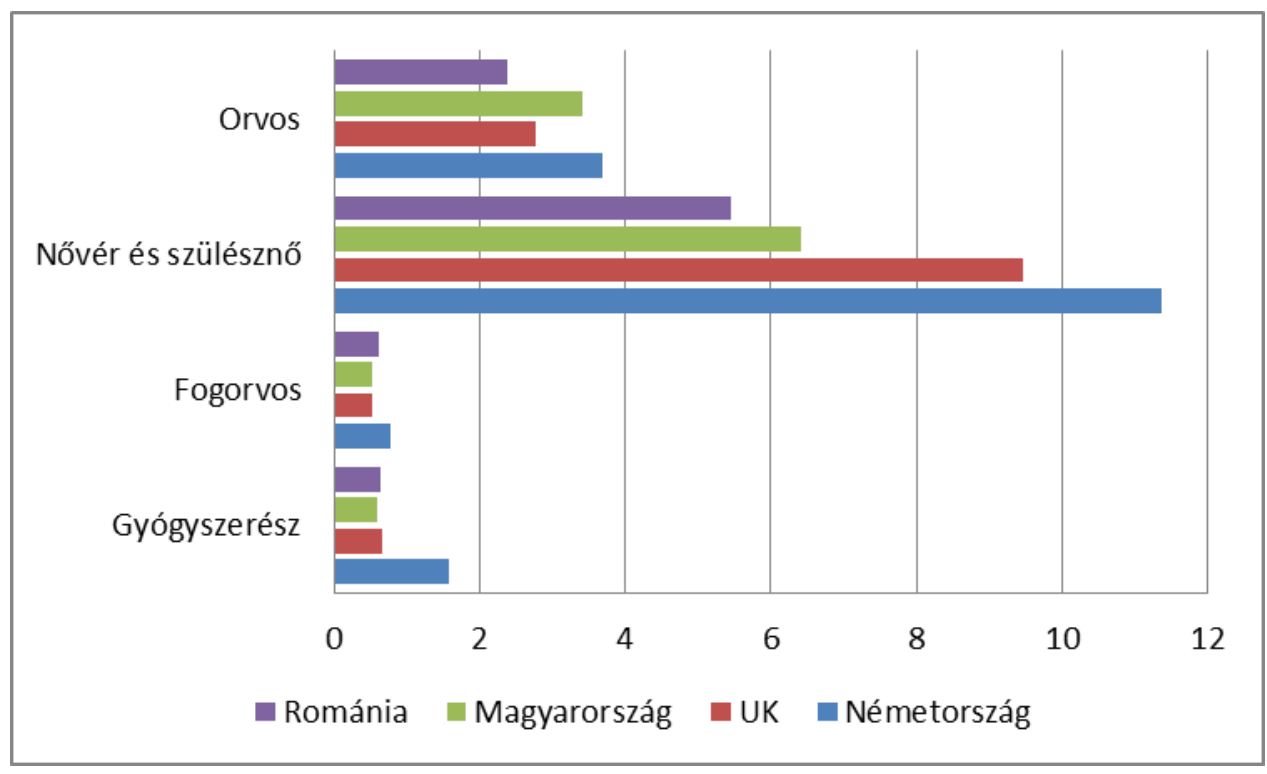

Forrás: World Health Organization (WHO 2014)

A Romániában lévő nővér és szülésznőhiány csakugyan szembeötlő, ami tovább erősítheti a migrációs hajlandóságot a még nem elvándorlókra háruló többletmunka, a túlterheltség révén (Greco 2010). A szakorvosokkal való ellátottság terén is történhettek az elmúlt négy évben kedvezőtlen változások, főleg ha a külföldi munkavállaláshoz szükséges igazolást kiváltó orvosok csakugyan el is vándoroltak.

A Magyarországra áttelepült és itt szakmájukat gyakorló egészségügyi dolgozók száma a diploma-honosítási adatokból tudható meg. A nyilvántartásnak az Egészségügyi Engedélyezési és Közigazgatási Hivatal (EEKH) a rendszergazdája jelenleg.

${ }^{81}$ Az Egyesült Királyság esetében 2011-es adatok állnak rendelkezésre (kivétel: a gyógyszerészek esetében 2010-es adat). 
4. ábra: A Romániából Magyarországra érkezö egészségügyi dolgozók száma, a honositások és elismertetések alapján ${ }^{82}$

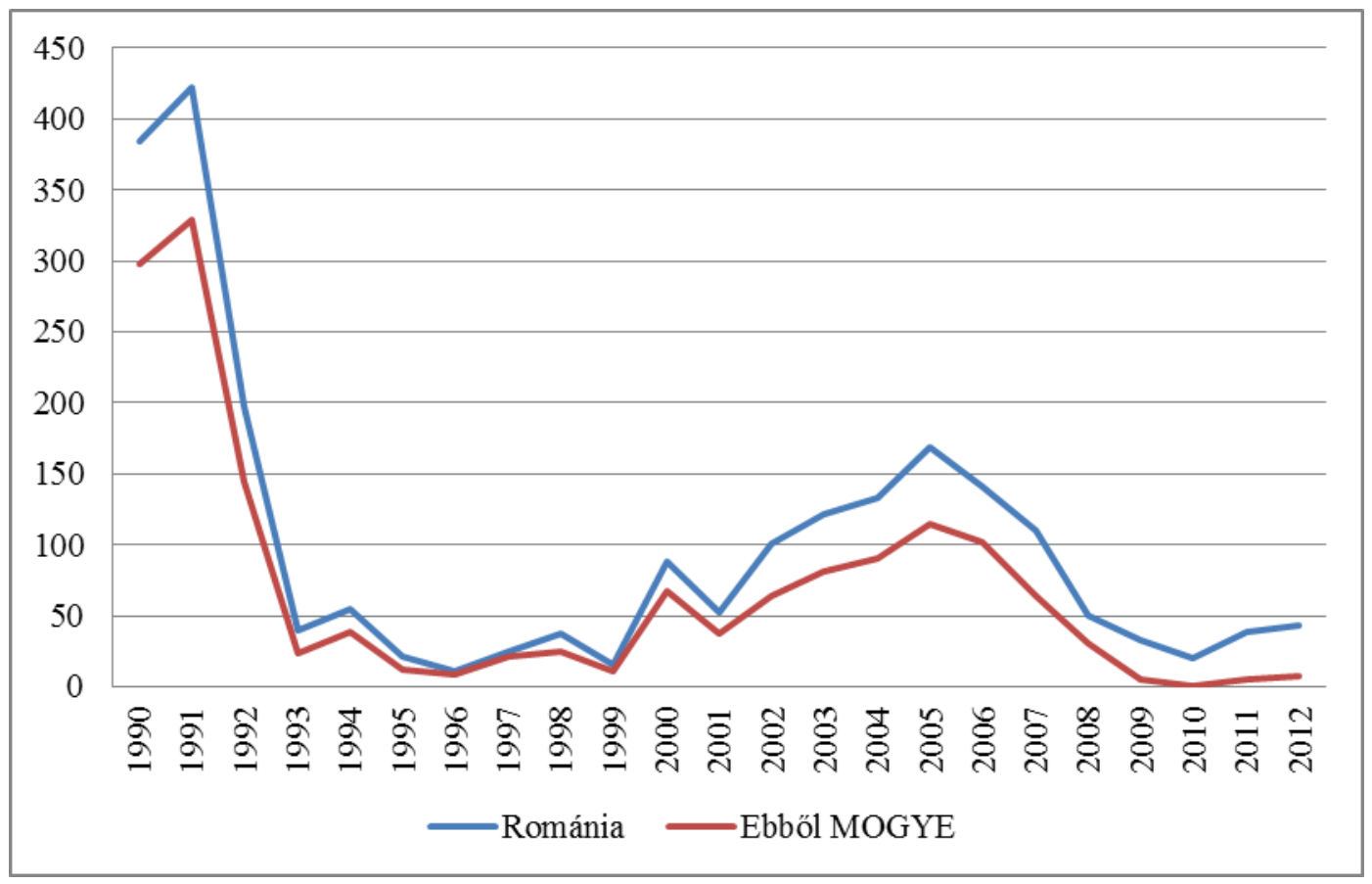

Forrás: az EEKH adataiból saját számitás alapján

Megj.: más romániai orvosi egyetemek, ahonnan érkeztek egészségügyi dolgozók: Kolozsvár, Temesvár, Bukarest, Jászvásár (Iasi), Nagyvárad, Arad és Craiova

A Marosvásárhelyi Orvosi és Gyógyszerészeti Egyetem - mint egészségügyi migránsokat kibocsátó intézmény - domináns szerepe egyértelműen megmutatkozik az adatokban, az áttelepültek közel kétharmada ennek az intézménynek a végzettje. ${ }^{83}$ Két csúcspont figyelhető meg a vándorlási folyamatban: az egyik a 90-es évek elején, a rendszerváltás következtében megnyílt határok eredményeképpen, a másik 2005-ben, Magyarország EU-s csatlakozását követően, amely esemény ráerősített a 2002-ben valószínűleg a státustörvény hatására - ismét növekedésnek indult vándorlási kedvre. Románia belépése az Európai Unióba más irányba terelte, illetve megkönnyítette a szakemberek nyugati országokba vándorlását, amely hatás a MOGYE végzettek esetében a Magyarországra irányuló migrációban azonnali törést eredményezett.

A MOGYE kibocsátóként és a magyar egészségügy szakember hiányának pótlásában játszott kiemelkedő szerepe már korábban is felkeltette az érintettek

${ }^{82}$ A nővérek és ápolók nem szerepelnek ebben a táblában, mivel csak 2002-től vannak róluk adatok. Az 1990-ig visszamenőleges adatok megszerzésére számos kísérletet tettem, de végül eredménytelenül (az érintett időszak alatt az adatgazda és honosítási jogszabályok változásai miatt).

83 A részletekért lásd az 5. mellékletet. Azt, hogy egyes évfolyamokon belül milyen arányú volt a Magyarországra való vándorlás, sajnos nem áll módomban megállapítani, mivel nem rendelkezem a diploma kiállítási évének ismeretével. Az adott évben végzett magyar hallgatók számát pedig értelmetlen összevetni az ugyanazon évben történt honosítások számával, hiszen a vizsgált időszak kezdeti csúcséveiben sokkal több MOGYE-n végzett egészségügyi dolgozó honosított, mint ahányan a magyar tannyelvü szakokon diplomáztak azokban az években (lásd a 6. mellékletet). 
figyelmét, amelynek hatására néhány éve (2009-ben) a SOTE és a MOGYE néhány professzora közös kutatást végzett (Ábrám 2011). Ez a kutatás egy jóval nagyobb időterjedelmet foglal magában, visszamegy a Marosvásárhelyre költözött egyetem müködésének majdnem a kezdetéig, viszont csak az orvosokkal (általános orvos és fogorvos) foglalkozik az 1953-2008 közötti időszakban. Számításaikat szintén az EEKH-tól kapott adatokra alapozva végezték, a kapott számadatok viszont jelentős eltérést mutatnak az általam eredményül kapott számoktól; jóval magasabbak az övéik, akár százas nagyságrendű eltérések is vannak egyes években. ${ }^{84}$ Ám a kutatás nagy érdeme, hogy az adott évben honosított diplomák esetében nemcsak a kiállító intézmény nevét, hanem a kiállítás évét is beazonosították. Ezáltal lehetővé vált az úgynevezett „csúcsévekben” bekövetkezett átvándorlás részletesebb elemzése, amelyböl kiderül, hogy mely évfolyamokra volt leginkább jellemző a migráció. Míg az első migrációs hullám hátterében nagyon eltérő korosztály - tág időbeli skálán diplomázott orvos csoport - áll, a 2005-ben honosítottak túlnyomó többsége frissen végzett, azaz 20032004-ben szerzett orvosi oklevelet (Ábrám 2011).

A szakterület szerinti megoszlások vizsgálatakor ${ }^{85}$ kisebb eltérések tapasztalhatók: a 90-es évek eleji nagy migrációs hullám hasonlóképpen zajlott le valamennyi szakterület dolgozói körében. ${ }^{86} \mathrm{Az}$ ezredfordulón megnövekedett migránsok számának visszaesése figyelhető meg 2001-ben, majd ismételt emelkedése 2002-ben. Míg az átvándorolt orvosok száma töretlenül ível fölfelé 2005-ig, majd irányt vált és 2008-ban drasztikusan lecsökken, illetve 2011-ben ismét elindul fölfelé, addig a fogorvosok esetében ez a trend 2-3 év késéssel és kevésbé élesen jelenik meg. Számuk jóformán változatlan a 2002-2004 közötti időszakban, majd 2005-ben megugrik kissé és kisebb hullámzással, de 2007-2008-ban is magas marad, és csak 2010-ben esik nagyon vissza. 2011-től, ha kisebb mértékben is, mint az orvosoké, számuk ismét növekszik. A gyógyszerészekről - mivel szám szerint ők vannak a legkevesebben - nehezebb következtetéseket levonni. Esetükben viszont a 2002-es év jelenti a csúcsot, és a fokozatos csökkenés 2007-ben gyorsul fel, illetve a 2011-es növekedési trend nem jellemző rájuk.

Annak megállapításához, hogy sajátosnak mondhatók-e ezek a migrációs trendek, vagy az erdélyi magyarok vándorlási tendenciáit követik, az alábbi grafikon

\footnotetext{
${ }^{84}$ A kutatás egyik vezetője az időközben az adatbázison végzett tisztításra gyanakszik. Viszont ezt az EEKH nem erősítette meg. Hárs is közel 1600 föt említ, akik munkavállalási engedélyt szereztek 1991 első felében (Hárs 1992b). Ezen tág kategóriába viszont valószínüleg a nővérek, ápolók és akár más, a kutatás által nem vizsgált szakszemélyzet is beletartozhat.

${ }^{85}$ Lásd a 7. mellékletet.

${ }^{86}$ A nővérek (egészségügyi asszisztensek) adatait nem tartalmazza.
} 
nyújt segítséget, amely a Romániából érkező bevándorlók számát ábrázolja és a 2000-es évek migrációjára enged részletes rálátást. ${ }^{87}$

5. ábra: Romániából Magyarországra érkezö bevándorlók számának alakulása

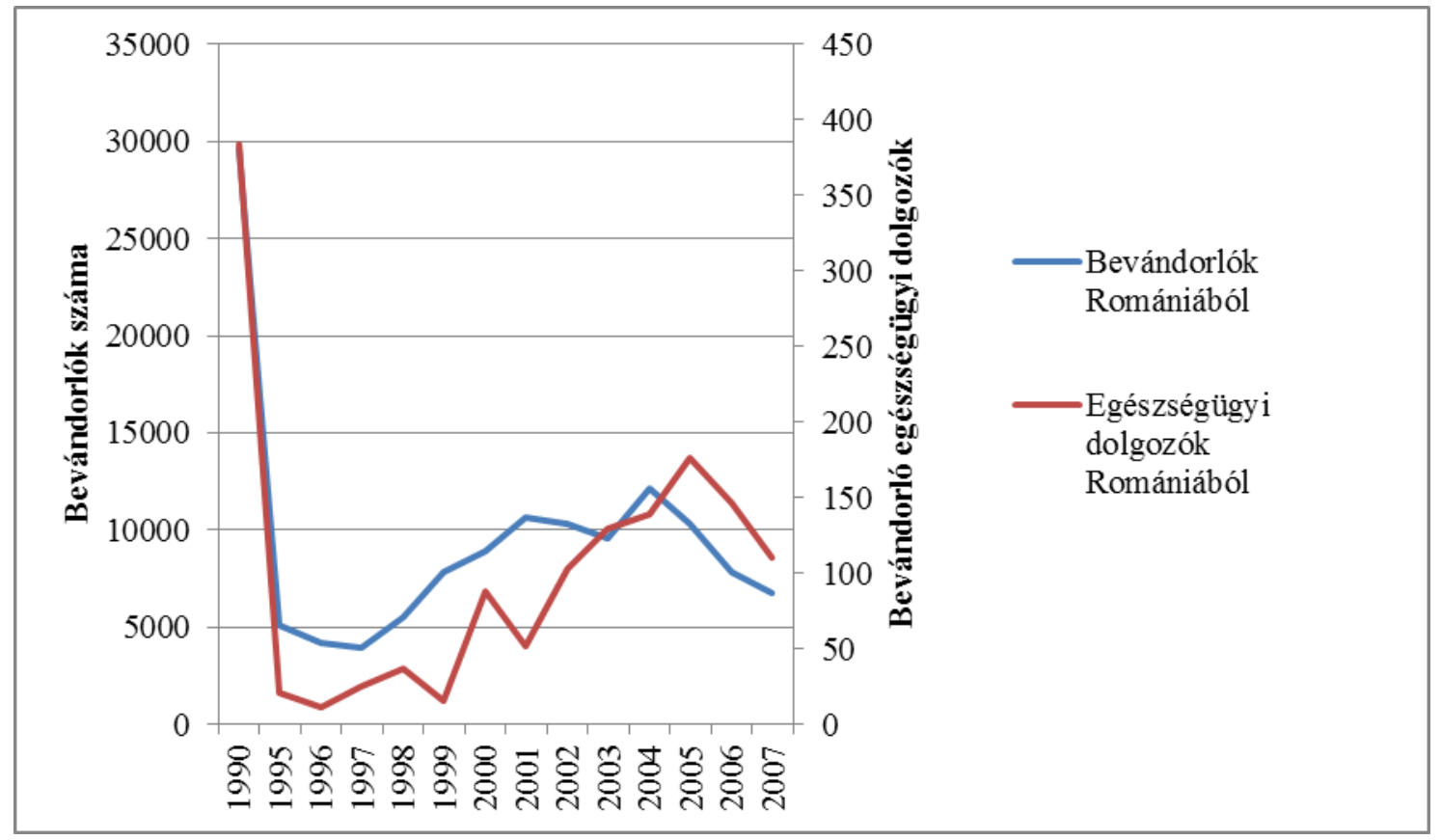

Forrás: KSH Demográfiai Évkönyv 2007 és EEKH adatai

Romániából Magyarországra vándorolt migránsok számának növekedése tulajdonképpen már 1998-ban elindul és fokozatosan növekszik, majd a 2003-as évi kisebb visszaesés után 2004-ben éri el csúcsát, illetve 2006-ban már nagyon lecsökken. A két csoport adatainak összehasonlításakor nem mutatkoznak jelentős eltérések, egymással ütköző trendek; jóllehet megállapítható, hogy az egészségügyi dolgozók migrációja a 2000-es években néhány évvel később kap lendületet, illetve a csökkenésében bekövetkezett éles törésvonal is 1-2 évvel később jelentkezik (MOGYE végzetteknél 2007-ben, általában a romániai egészségügyi dolgozóké pedig 2008-banlásd: 5. melléklet). Általánosságban viszont megállapítható, hogy a romániai egészségügyi dolgozók mozgása többnyire beleilleszkedik a Romániából Magyarországra vándorlók migrációs trendjébe.

\footnotetext{
${ }^{87}$ Csak származási ország szerinti adatok állnak rendelkezésre, de ezek megfelelő viszonyítási csoportot jelentenek, hiszen amint azt az erdélyi magyar migrációs kutatók megállapították, a Romániából érkező bevándorlók túlnyomó többsége magyar nemzetiségü (Hárs 2010; Gödri \& Tóth 2005). Ezért is használtam szinonimaként az erdélyi magyar és romániai bevándorlókat.
} 


\section{MIGRÁNS NARRATÍVÁK - DÖNTÉSI MECHANIZMUSOK}

Ebben a részben azt próbálom megérteni, hogy a már átvándoroltak hogyan mutatják be a jelenből visszatekintve vándorlási történetüket. Ehhez a narratív interjút használtam, amely módszer szabadon tárja fel a vizsgálni kívánt mechanizmusokat.

A globalizációs folyamat eredményeképpen az éles földrajzi határok elmosódnak, ami maga után vonja a kulturális és társadalmi választóvonalak képlékenyebbé válását is. Ezzel együtt az országhatárokon átívelő migráció is és a migráns identitásáról alkotott kép is megváltozik: már nem egy egyszeri és befejezett eseményt, illetve egy új kultúrába való asszimilálódási folyamatot jelent, hanem akár többszöri oda-vissza mozgást, a kibocsátó és a befogadó közösséghez való egyidejü tartozást, melyben az identitás is komplexebbé válik (Bodó 2008; Kovács \& Melegh 2007). Ebben a határok fölött „lebegő” helyzetben a migránsnak nemcsak a környezete, hanem önmaga számára is újra kell értelmeznie önmagát, megváltozott helyzetét és emberi viszonyait. Mivel a társadalmi identitásunk részben a magunkról hallott és általunk elmondott narratív történetekből épül fel, a migráns is különböző szövegeket, narratív sémákat keres, melyek segítségével összefüggő történeteket alkot magáról és amelyekkel értelmet ad a vándorlásának (Kovács \& Melegh 2004; Kovács \& Melegh 2001). Ezek feltárására irányuló vizsgálatok olyan kvalitatív interjús módszert alkalmaztak, amellyel a beavatkozás mértékét - tehát a kutató által használt fogalmak konnotációinak hatását - a lehető legkisebbre igyekeztek csökkenteni: a narratív életút interjú mintájára használt narratív migrációs történetet (Rosenthal 1993; Kovács \& Melegh 2001). A narratív interjú lényege, hogy nyitott az alanyok felé, vagyis lehetővé teszi, hogy „hallassák a hangjukat”, azaz szabadon mesélhetik el történetüket. Így megpróbálja elkerülni, hogy az élettörténetben használt fogalmak alárendelődjenek az uralkodó társadalomtudományi és politikai elméleteknek, illetve képesek az elbeszélő által használt összetett kognitív formákat elemezni (Kovács \& Melegh 2007; Kovács \& Melegh 2001).

A narratív interjú nyújtotta előnyök és sokszínüség kihasználására törekedve az Erdélyből bevándorolt egészségügyi dolgozókkal készített félig strukturált interjúk többségét - ahogyan a módszertani részben erre történt utalás - a migrációs történet 
szabad elmesélésére buzdító kérdéssel indítottam. ${ }^{88} \mathrm{~A}$ megkérdezett orvosok és nővérek migrációs történetüket általában nagyon szükszavúan, a vándorláshoz vezető okokra szorítkozva adták elő. A hozzájuk intézett kérdésekre további adatokkal szolgáltak, melyek világosabbá, érthetőbbé tették a narratívában elmondottakat, esetenként alátámasztva azt az önmagukról alkotott képet, melyet az indító történetben bemutattak, máskor pedig mintegy elszakadva tőle, egy másik fajta 'én' jelenik meg, amely akár ellentétben is állhat az előzővel, vagy akár váltakozva: hol egyik, hol a másik szólal meg. Az első eset magyarázatát abban látom, hogy egyfelől az elbeszélő által a kezdetben megválasztott tematikus mezö (Rosenthal 1993) annyira meghatározza a történetet, azt, hogy miként mutatja be önmagát, hogy vagy következetesen marad ezen a területen vagy egyszerüen képtelen ebből kilépni, ami egy feszültség forrássá válik további válaszaiban. Másfelől természetes, hogy az egyén különböző helyzetekben más és más pozíciót vehet fel a többi szereplőhöz és korábbi önmagához képest, amelynek célja, hogy a hallgatóját megpróbálja bevonni saját tapasztalataiba és nézőpontjába (Riessman 2012). És mindezt - értelmezi a múlt tetteit és azok mozgatórugóit - a jelen perspektívájából nézve teszi. Mindezekből kiderül, hogy a narratívák nagy kihívást jelentenek mind az elbeszélőnek, aki bizonyos identitás állítás(oka)t fogalmaz meg és különböző társadalmi pozíciókba helyezi önmagát, miközben megpróbálja vándorlásának történetét megalkotni; mind a kutató számára, aki megkísérli ezeket a bonyolult összefüggéseket elemezni és interpretálni.

Az interjúk kódolását a következőképpen végeztem: a narratív interjúk esetében elöször a narratív részt kódoltam le. A kódolás kezdeti szakaszában megpróbáltam a Rosenthal által kidolgozott hermeneutikus módszert, illetve ennek a Kovács-Melegh páros által adaptált változatát alkalmazni (Rosenthal 1993; Kovács \& Melegh 2001; Kovács \& Melegh 2007). Mivel a narratívák többsége meglehetősen rövid, ${ }^{89}$ a módszer egy egyszerüsített változatát használtam, és az elemzést aszerint végeztem, hogy a migránsok hogyan látják és jelenítik meg a jelenből a múltba nézve vándorlásukat. A narratívákat tehát aszerint kódoltam, hogy a mesélő milyen motivációkkal indokolja (pl. családi, szakmai), illetve milyen tényezőkkel legitimálja migrációját, és hogyan jeleníti meg önmagát és az eseményeket a vándorlástörténetében (pl. van-e döntéstörténet vagy csak sodródás, aktív vagy passzív szerepben mesél), majd ezeket összevetettem az interjú további részeivel, amelyek vagy alátámasztották vagy cáfolták a narratívában

\footnotetext{
88 A továbbiakban folyamatosan jelzem, hogy az éppen elemzett vagy idézett interjúrészlet esetében narratív interjúval van-e dolgunk vagy sem. Ám ez a fajta különbségtétel sem olyan egyértelmü. Arra is van példa, hogy a családi háttérről érdeklődő indító kérdésre az interjúalany önként elmeséli migrációs történetét.

${ }^{89}$ Ez részben az interjú alanyok szűkös időkorlátainak, másfelől az én, ebben a módszerben való kutatói tapasztalatlanságomnak is köszönhetö.
} 
bemutatott képet. Az aktív-passzív szerep jelentősége abban áll, hogy jelzi azt, hogy maga az egyén mennyire tartja elfogadottnak a vándorlást.

Az interjúkban a migráció fő motivációiként a következő tényezőket említették: család és párkapcsolat, szakmai boldogulás, jóléti okok (magasabb kereset és életszínvonal), kisebbségi léthelyzet, korábbi migrációs tapasztalat, egészségügyi problémák. Az elvándorlás legfontosabb okaiként bemutatott tényezők között a következő összekapcsolódások figyelhetők meg:

Családi jóléti Karrierista Etnikai

Szakmai Nem szakmai Családi Egyéni Szakmai Diszkriminációs

Mindezek alapján különböző típusokat különböztettem meg. Természetesen legjellemzőbb a különböző motivációk és típusok keveredése. Mivel a csupán félstrukturált interjúkban is rákérdeztem a vándorlás okaira, a fenti logika mentén ezeket is bevettem az adott csoportokba, ${ }^{90}$ jóllehet ez utóbbiak esetében utalok arra, hogy nem narratív interjúról van szó.

Migráns/narratíva típusok:

\subsection{Családi jóléti migráns}

\subsubsection{Családi jóléti-karrier orientált migráns}

Ennél a típusnál hangsúlyos a párkapcsolat, a Nyugaton megszerezhető magasabb bérek, de emelett szakmai okok is helyet kapnak a vándorlástörténetben, mint az otthon kudarcba fulladt - az alig elkezdett vagy el sem kezdett - szakmai pálya vagy az önmegvalósításra való törekvés. Illetve egészségügyi problémák is szerepet játszottak a migrációs döntés meghozatalában.

LP történetében is egyik központi motiváció és szereplő a párja, aki miatt - és mint később kiderül, akivel együtt - vándorolnak Magyarországra. Viszont LP döntésében párja szerepe nem annyira kizárólagos, mint például RI esetében, mert a narratívában egy önálló döntéshozatal is megjelenik egészségügyi problémája kezeltetésének szándéka kapcsán. Bár a narratíva elején csak utalás történik rá, válaszaiból megtudható, hogy ez a vándorlástörténet is egy tágabb mintakövetésbe, egy csoportos - iskolatársai részére intézményesen megszervezett - toborzásos migrációjába van beágyazva.

„Hát én R-ben végeztem el az egészségügyit, és igazából akkor a csoporttársaim ide kijöttek Magyarországra. Én meg két évet nem. Elöször is voltam Németországban

${ }^{90}$ Mivel az összes interjúnak közel kétharmadát teszik ki, nagy veszteség lett volna teljesen kihagyni öket az elemzésböl. 
majdnem egy évet, aztán dolgoztam otthon egy évet, és hát ez a kérdés, hogy miért vagyok itt? Hát egyrészt barátom miatt, most már férjem, tehát egyrészt az akkori barátom miatt, másrészt nekem hormonzavarom van, és akkor azt úgy nagyon akartam kezeltetni, én kis naiv. Elég komplikált. Tehát vagy P vagy Bukarest, és azt mondtam, hogy $P$, mert ott megértenek és megértetem magamat." (LP, nő, nővér)

Válaszaiban mindkét tényező - párkapcsolat és munkahely - fontos szerepet kap, a kisebb történetek néha a párjáról, máskor pedig a munka- és migráns társairól szólnak. Önála, illetve majd EP-nél jön elő rögtön az indító narratívában a volt sorstársak visszavándorlásának említése. Erre egyfelől magyarázatként szolgálhat az erős kollektív szolidaritás - hiszen csoportosan, együtt érkeznek, és már előtte is ismerték egymást -, másfelől utalhat arra, hogy a visszavándorlás csakugyan a nővéreket érintette leginkább (Balogh 2009). Hiszen az orvosok, fogorvosok inkább a kollégák továbbvándorlását említették; jóllehet visszavándorlókról is beszámoltak.

A - legalábbis részben - önálló migrációs tervezés képét a továbbiakban is igyekszik fenntartani, felsorakoztatva motivációit (és ezek között az egészségügyi probléma csak egyik), amelyek a vándorlás tervezéséhez vezettek. A karrierjében és életében „valami többet" elérni vágyó, önmegvalósításra és kalandra törekvő, és saját értékelése szerint ezt meg is valósító nő képe kevéssé idomul a narratívában bemutatott, párját követő nőéhez. A kettő közötti szakadékot a különálló migrációs tervek, de közös döntéshozás mozzanatával hidalja át.

„, Tehát egy évet, vagy szüken egy évet voltam kint, aztán egy évet dolgoztam otthon. Otthon fogyatékosokkal dolgoztam. És akkor igazából... furcsa volt, egy idő után azt éreztem, hogy nem elég, és én többet akarok csinálni. (...) És akkor jött ez a lehetöség, hogy egyrészt beszéltem a barátommal, és mondta, hogy hát, ő is feljönne P-be. Ö járt Magyarországra dolgozni, ő is feljönne Pestre dolgozni, itt van a testvére, és akkor meg nyilván még ritkábban jött volna haza. És akkor... meg már bennem is érlelödött, hogy valamit váltani kéne, valami többet... És mivel a csoporttársaim idejöttek ebbe a kórházba, így én is idejöttem. Mikor én jöttem, akkor is jött egy csapat. Tehát sokan jöttünk. Kevesen vagyunk közülük itt.” Máshol: „Ami viszont érdekes, hogy majdnem ugyanezzel a, tehát ugye ez történt vele, és így beszélgetett a testvérével, és ugyanez megfogalmazódott bennem, töle függetlenül, hogy jó lenne kijönni ide Budapestre, mert tudtam, hogy a lányok végül is, akikkel kijöttem, hogy azok készülnek ide ki, és valahogy úgy megfogalmazódott bennem. Tehát majdnem egyszerre vele együtt, és mégis egy kicsit külön, hogy mi lenne, ha. És akkor igazából igy kijöttünk.” (LP) 
Az össztörténetnek (a narratívát kiegészítő kérdésekre adott válaszokat is beleértve) egy fontos eleme az erdélyi identitás, a magyarországi magyarokkal szembeni „másság” fontosságának hangsúlyozása, annak megélése, ami egy „mi-ők” (erdélyi magyarmagyarországi magyar) ellentétpár felállításához vezet. ${ }^{91}$

Az erdély magyar identitás jelen esetben nem a vándorlástörténet során, hanem a jövőbeli terveket illetően jön elö; jóllehet az etnikum kérdésköre a magyar nyelv használata kapcsán már korábban is felmerül.

„[É]n úgy gondolom, hogy teljesen más mentalitás az, ahogy otthon felnöttünk, és... és énszerintem nagyon nehéz úgy megtalálni a társat, hogy egy magyarországi és egy erdélyi. Van ilyen, mert van ismerösöm, barátom. Én látom a különbséget, és nekem fura; elfogadok, én mindent elfogadok. Nekem fura. Viszont azt tudom, hogy milyen óriási nagy segitség, hogy mindketten erdélyiek vagyunk. Együtt jöttünk ki és megvagyunk egymásnak. Tehát ez egy óriási erō. ’(LP)

KE egészségügyi problémával küzd, és részben ennek tulajdonítja Erdélyben ért kudarcait. Vándorlástörténete - amely elsősorban egészségügyi állapota és szakmai pályafutásának, illetve annak kudarcának ismertetéséből épül fel - központi szereplője ő maga, mégis párja az, aki a migráció melletti döntést először meghozza.

„, Otthon voltam akkor nyolc hónapot, és akkor igy maradtam volna is, meg mentem volna is, de igy folyamatosan kerestem a lehetöségeket, és igazából én szerettem volna kutatni, (...) aztán valaki más esélyes került oda, úgyhogy az ott kudarcba fulladt, és mivel a párom, neki ugye, ö sebészeti ágban szeretett volna rezidensvizsgázni, hát ő is megpróbálta kétszer, de hát amint tudjuk, sebészként sem olyan egyszerü elhelyezkedni. Hát neki nem sikerült másodszorra sem a rezidensvizsgája, úgyhogy ő döntött, mert ide egyböl felvették, és akkor meg közben én is kaptam itt kint PhD hallgatói ösztöndijat, és akkor így én is jöttem értelemszerüen. Ennyi." (KE, nő, orvos)

Saját döntéshozatala sokáig egy nyitott végü, elhúzódó folyamat, amelyet a párkapcsolatától függetlenül, a karrierjére fókuszáltan jelenít meg.

\footnotetext{
91 Az Erdélyből Magyarországra vándorlók sajátos erdélyi identitásának kialakulásáról és müködési mechanizmusáról bővebben lásd pl. Fox és Biró tanulmányait. A migráns a saját világát védve el- és „átbeszéléseiben” távolságot próbál teremteni az idegen világgal szemben, sőt a saját világát helyezi az idegen fölé. Az idegenség érzését növeli a migráns izolált állapota is vagy - akár időszakos - megalázott helyezte, státusvesztése munkavállalóként (Biró 1996; Fox 2003).
} 
„,Elmentem, megnéztem több helyet is, és akkor végül elmentem állásinterjúra arra a helyre, ahová végül PhD. hallgatónak fel is vettek, és akkor úgy döntöttem, hogy megyek. Ök sokáig nem, tehát lefagyasztottam az ottani rezidensképzést, csak akkor mondtam fel, amikor már eldöntöttem, tehát lejárt a PhD. hallgatói státuszom, és akkor eldöntöttem végleg, hogy itt leszek rezidens és nem otthon, tehát itt is jelentkeztem a rezidensképzésbe, és akkor az otthonit lemondtam” (KE)

A döntés elodázásának és kezdeti fel nem vállalásának hátterében a migrációt elítélő normavilág áll (Gödri 1998; Kovács \& Melegh 2007); explicit módon a családja támogatásának hiánya, aki nehezen engedi el.

„Hát a szüleim elöször nehezen fogadták el, lévén, hogy egyetlen gyerek vagyok, de utána meg úgy gondolták, hogy mindegy, hogy hol vagyok, az a lényeg, hogy én jól érezzem magam. Tehát hogy boldog legyek abban és ott, amit csinálok. És egy idö után megtanulták azt, hogy ekkora távolságra élünk, ez mégsem akkora távolság, mert van internet, van telefon, van Skype. ${ }^{92}$ Akkor idönként jönnek ök is, idönként hazamegyünk, meg ök is igazából a korukhoz képest ilyen mobilisek, tehát szívesen jönnek ök is ide nyaralni. Hát így elfogadták. Mert ez volt a fö lényeg, hogy nekem jó legyen. De ehhez kellett egy kis idö, tehát kellett egy olyan jó két év, három, amíg ezt így teljesen békében el tudták mondani." (KE)

Erre a típusra nagyon jellemző a lebegő-sodródó léthelyzet. ${ }^{93}$ A lebegő létforma a transznacionális migránsokra jellemző és a migráns többes kötődéséből - mind a kibocsátó, mind a befogadó közösség tagja - ered (Brettel 2000; Portes 1999; Conway 2000; Glick Schiller et al. 1995). Némely interjúalany esetében csakugyan a származási közösséghez való szoros kötődésből és az egykori visszatérés szándékából következik. Viszont olyan migráns is található, akinél ez inkább a kapcsolatok megszakítását és abból következően a sodródás, a kitágult referenciatérben az önérdekek szabad követésének, egyfajta kollektív identitásvesztésnek az állapotát jelenti. Ebből adódik, hogy általában további migrációt terveznek: ez utóbbi csoport tagjai többnyire

\footnotetext{
92 A migráció normalizálódásával megnő a két világ (amely kettőnél több országot is magába foglalhat) közötti átjárhatóság (Bodó 2008).

93 Ezzel a „mobilis” identitással máshol is találkozunk ugyan, de ennél a típusnál jelenik meg a leghangsúlyosabban.
} 
Nyugatabbra szándékoznak menni, ${ }^{94}$ az előbbi pedig a visszatérést fontolgatja; Magyarország csak átmeneti állomássá válik.

„[E]lég sokszor ott volt a levegöben, hogy hazamegyünk. Tehát azért van az, hogy például a diplomahonositásomat is eléggé húztam. Az állampolgárságom most már megvan úgy kilenc év után, de elég későn adtam be. Tehát annak ellenére, hogy egyrészt nagyon sok papírmunka, meg minden. Másrészt meg, mikor úgy nekifogtam volna, hogy csináljam, akkor mindig volt valami, hogy á, úgyis fél éven, éven belül hazamegyünk, és akkor minek. Igazából, tehát ez egy stabil munkahely nekem. És őrült módon szeretem azt, amit csinálok, mert azt hiszem, hogy enélkül nem tudnám csinálni, bármilyen munka is lenne. Viszont a férjemnek, hát most egy stabil helyen dolgozik, és neki úgy most kialakulóban van, hát ha úgy mondtam, karrier, nem szeretem ezt a szót, de úgy neki is egyre jobban megy, és akkor most úgy tünik, hogy talán maradunk. Mindig az volt az érzésem, hogy a gyerekeim nem itt fognak felnőni. "95 (LP)

„, Hát ez ilyen, ilyen mobilisak vagyunk. Mindenki kérdi, hogy mikor döntjük el, hogy hol akarunk élni. De én úgy gondolom, hogy amíg a gyerek nem jár iskolába, amíg nincs gyerek, aki iskolába járna, addig teljesen lehet követni minden egyéb érdeket. Tehát így nem kötödünk egyik városhoz sem Magyarországon annyira, hogy most onnan ne tudjunk elmozdulni, ha valami ésszerü vagy jobb érdek nem kívánja." Máshol: „Mindenki azt érzi, hogy közelebb, könnyebben átjárható a két ország, inkább azért, mert úgy nehéz volt elszakadni. De miután már elszakad az ember, akkor utána már nem érzi ezeket a távolságokat, tehát igy rájön, hogy mindegy, hogy egy határral vagy három határral van odébb, hogy így átjárható, vagy nem tudom, inkább ezért.” (KE)

„Magyarországhoz igazából nem köt semmi, igy is- úgy is messze vagyok az otthoniaktól, úgy meg közelebb lennék a barátnömhöz és a családjához, illetve a szüleihez.” Máshol: „Magyarországhoz képest minden olyan távol van. Nem fizikailag, hanem minden egy ismeretlen világ volt akkor, hogy eszembe sem jutott megpróbálni. Ez így egyszerübb volt: nyelvi probléma nem volt, viszonylag könnyen meg lehetett oldani ezt az egész munkavállalási ügyet. Mert ugye attól függött minden. Azóta már kicsit kinyilt a szemem (nevet), meg a lehetöségek is, meg egyéb...” (ON, férfi, orvos)

\footnotetext{
${ }^{94}$ Esetleg majd a nagyon távoli jövőben szándékoznak visszatérni szülöföldjükre.

${ }^{95}$ Férje nyelvtudása hiányában vetették el a nyugati munkavállalás tervét.
} 
ON is párkapcsolatára és szakmai okokra hivatkozva mesél vándorlásáról. ${ }^{96}$ Ugyancsak ezeket és más jóléti okot (magasabb jövedelem) említ jövőbeni tervei, azaz továbbvándorlási szándéka kapcsán. Egyedi az, ahogyan fogalmaz: nem annyira az elvándorlás mellett való döntésé, mint inkább az otthon maradás, az ottani korlátozott lehetőségek, jövőkép elutasításáé a főszerep (Gödri 2010).

„[V]égeztem, és akkor nem is terveztem otthon maradni. Részben azért, mert a barátnöm cseh és kicsit közelebb igyekeztem hozzá, de az a szakma, amit én szerettem volna csinálni nagyjából, ahhoz Romániában nem igazán volt feltétel, meg nem is volt, nem is létezett ilyen formában az a szakma (...) az orvosin belül. Itt Magyarországon viszont elég régóta és jól müködött, úgyhogy azért is jöttem ide...” Máshol: „Soha nem is akartam volna Romániában, és egyre kevésbé akarok ott dolgozni” (ON)

A párkapcsolatra vagy szakmai okokra való hivatkozáson túl, - amelyek mellett az egyéni döntés is megjelenik - ennek a típusnak lényeges jellemzője a mintakövetés, a korábbi (de akár saját évfolyamukról csoportosan vándorló) migránsok hálózatai tevékenységének a hatása. Elsősorban az információforrás szerepét töltik be ezek a kapcsolatok, de a terep előkészítését is segíthetik: a személyes körülnézést, érdeklődést külföldön. ${ }^{97}$

„,[I]nterneten kerestem információt, meg hát érdeklödtem azoktól, akik igy külföldön voltak. Többekkel is eljöttem, ilyen szabadidömben kijöttem, beszélgettem azokkal, akik itt vannak, meg is látogattam, több helyre elküldtem az önéletrajzomat, több helyröl visszajeleztek. Elmentem, megnéztem több helyet is, és akkor végül elmentem állásinterjúra arra a helyre, ahová végül PhD hallgatónak fel is vettek.” (KE)

A migráns hálózat hatása $\mathrm{ON}$ esetében már a szakterület választás kapcsán megjelenik, majd az információszerzésben, később az adminisztratív ügyek intézése során.

„[I]lyen sebészeti szakmákat sosem szerettem, belgyógyászathoz sem nagyon fülött a fogam, viszont valami manuális, valamilyen gyakorlatias dolog tetszett, ami mozgásszervekkel foglalkozik. Otthon leginkább az ortopédia állt közel, de az ugye

\footnotetext{
${ }^{96}$ Nem narratív interjúról.

97 A magasabb társadalmi-gazdasági státusú migránsok rendelkeznek - több erőforrás birtokában - azzal a képességgel, hogy már a tényleges elvándorlást megelőzően kiterjedt információ- és álláskeresést valósítsanak meg vagy meglátogassák a célterületet, amelyek a későbbi belépést megkönnyítik (Bagchi 2001).
} 
mütéttel jár, amit nem akartam. És aztán egyszer valaki hazajött, aki 2 évvel fölöttünk járt, egy srác, és ö mesélt róla ott a bentlakásban, hogy ilyen rehabilitációra jelentkezett (...) és akkor jöttem rá, hogy az épp nekem való” Máshol: „A honosítás meg úgy ment, hogy akkor azzal nagyon sokunknak gondunk volt. Pont ilyen átmeneti időszak volt, hogy Románia elötte lépett be az Unióba, tehát mi gyakorlatilag már uniós állampolgárokként jöttünk át, de még nem volt meg a kitaposott út, hogy hogyan is lesz a honosítással, a magyarok nem nagyon tudták, kicsit akadékoskodtak, mert nem tudták, hogy mit hogyan. És akkor ilyen össznép összefogás volt, sokan, így kb. 50-en-60-an támadtuk meg azt a hivatalt- nyilván páran intézték, de sokan voltunk mögöttük. És végül elfogadták, hogy ne kelljen egyenként, mindenkinek külön-külön mindent lefordittatni, egyenként intézni az ügyet, hanem úgy összességében megengedték, hogy egy bizonyos módon elfogadják és honositják a diplomákat viszonylag egyszerüen, nem kellett ilyen különbözeti vizsgákat tenni; ki kellett fizetni azt az igazgatási díjat, de nagyjából ennyi volt" (ON)

A migráns hálózatok a tájékoztatás és eligazítás mellett - mintegy ezek nem szándékolt következményeként - a potenciális migráns célterületének megválasztását is korlátozzák, becsatornázzák (Portes 1995; Guilmoto \& Sandron 2001; Portes \& Sensenbrenner 2001). Többször visszatérő kép a „kitaposott úton” való járás, ami megkönnyíti az előrehaladást és egyben a bevándorlók adott településen vagy intézményben való tömörüléséhez vezet. Ám arra, hogy ezeknek a „gócpontoknak” a kialakulásában a migráns hálózatokon túl a befogadó félnek is szerepe van, egy másik interjú világít rá. ${ }^{98}$

\subsubsection{Családi jóléti-nem karrier orientált migráns}

A családi (pontosabban: a vándorlás időszakában még csak párkapcsolati) viszonyok az elsődleges migrációs motivációk; legalábbis ezt az okot említette elsődlegesként az interjúalanyok majdnem mindenike. A más emberekhez füződő kapcsolatok középpontba helyezése, a másokhoz való viszonyban való önmeghatározás, illetve az érzelmi motiváltság hangsúlyozása általában együtt jár a passzív szereppel, amikor az elbeszélő nem kezdeményezője az eseményeknek, hanem elszenvedője azoknak, megesnek vele; továbbá a többes szám használata, a „mi”-narratíva jellemzi (Kovács \& Melegh 2004). Az eseményekkel való sodródás egészen odáig fokozódhat, hogy a narrátor az áldozat szerepében jelenik meg, a másik szereplő által szinte kényszerítve érzi magát a vándorlásra, feladva saját vágyait, terveit.

\footnotetext{
${ }^{98}$ Lásd az 5. típusnál: TC történetét.
} 
„A párommal ahogy végeztünk, egyböl eljöttünk. Valószinüleg én otthon is boldogultam volna. Mondjuk, nem volt rendelö, ahol konkrétan kezdhettem volna, de fogorvosként több lehetöség volt. A párom viszont, amikor végeztünk, mondta, hogy az otthoni fizetésböl nem lehet megélni, nemhogy még lakás, meg család meg bármi... És hogy ö jön el, és gondoljam meg, hogy jövök-e vele vagy maradok otthon (nevet). Végül is nehéz döntés volt, mert én nem akartam eljönni otthonról... De végül a párom miatt... na, akkor jó, jövünk.” Később: „Mondjuk, a férjem húzott maga után, mert én magamtól..." (RI, ${ }^{99}$ nö, fogorvos)

RI végig megmarad a párját, majd férjét követő nő szerepében. A migrációs döntés felelőssége mást terhel, ő inkább a párkapcsolatát tekintve volt választás elé állítva. ${ }^{100}$ $\mathrm{Az}$ országon belüli vándorlás esetében is következetesen férje a kezdeményező, ő minden esetben nehezen szánja rá magát az újabb költözésre, bár utólag „,belátja”, hogy döntéseik a férjét igazolták és számára is előnyökkel járt a migráció. Mivel a vándorlás döntésének felelősségét nem ő hordozza, következményeiről is szabadon beszélhet (Gödri 1998). Ám nem visszakozik, nem bánta meg, hogy követte párját, sőt, a szakmai téren szerzett tudásával legitimálja választása helyességét, miközben az országok közötti makrokülönbségekre (gazdasági fejlettség és szakmai színvonal terén) reflektál:

„De hogy én nem akartam kijönni, egy dolog. Mert én otthon is boldogultam volna a munkámban, de igy utólag, visszatekintve nem bántam meg, mert igy, ahogy beszélgettem évfolyamtársakkal és ismerösökkel, akik fogorvosok otthon, és láttam, hogy otthon nem sok a lehetöség. A rendelök sem olyan modernek, felszereltek, tehát nem olyan környezetben tudnak dolgozni, és a vevők, a páciensek sem tudják megfizetni a minöségi munkát (...)Úgyhogy én utólag tényleg nem bántam meg, mert kezdettöl modern rendelöben dolgoztam, ahol volt felszerelés, volt anyag, minden volt a kezem alatt. Nem az volt, hogy tudom, hogy ezt kellene csinálni, de nem tudja megfizetni a páciens, és akkor... nem tudom mi. Ilyen szempontból jó volt nekem is, hogy kijöttünk." (RI)

\footnotetext{
${ }^{99}$ Nem narratív interjú.

${ }^{100}$ Ez egy bevett, általános legitimizációs módszer (Gödri 1998).
} 
Közvetve anyagi nehézségekkel, pályakezdőként az alulfizetettség miatt felmerülő megélhetési problémával és alacsony státustól való félelemmel ${ }^{101}$ (Kiss \& Csata 2004; Gödri \& Kiss 2009; Rohova 2011; Glinos et al. 2011) - amit a párja jelzett felé közös jövőjük tervezése során - indokolja elvándorlásukat, közvetlenül pedig az érzelmi kötődéssel.

„Abból a pénzböl fogorvosként szerintem azért otthon is lehet keresni; általános orvosként akkor... hát 3 millió lejt- régi lejben-, annyit adtak. Akárhogy szoroztuk, osztottuk, semmire nem volt elég, nem hogy még lakást béreljünk vagy bármi. Mondta a párom, hogy nem azért tanult hat évet és még nem tudom, hogy mennyit fog, hogy ennyivel kiszúrják úgymond a szemét." (RI)

A továbbiakban kiderül, hogy a mintakövetés is szerepet játszik döntésükben, hiszen elmondása szerint „a párom évfolyamáról 50 százalék startból nem is keresett otthon munkát, hanem direkt idejött keresni. 25 százalék még megpróbált otthon dolgozni és utána jött el, és 25 százalék maradt otthon”. Ez a tömeges vándorlás egy migrációs kultúra jelenlétére utal, amelyben a migráció elfogadott életstratégia (Massey et al. 1994), legalábbis pragmatikus szinten. ${ }^{102}$

Tudatosan reflektál is a férje és közte levő gondolkodásbeli különbségre, illetve karrierjéről mesélve is kiderül, hogy elfogadja női szerepét, amit sikeresen él meg (Kovács \& Melegh 2004).

„, Barátok, minden otthon van, a szülők- ezért nem is akartam. Én inkább ilyen érzelmi beállítású vagyok, a párom racionálisabban gondolkodik. Én emiatt nem akartam eljönni, de végül is beláttam, hogy otthon nem sokat tudunk kezdeni (...) [n]em vagyok karrierista, meg nem szeretnék reggeltöl estig dolgozni, de... az a típus sem vagyok, aki otthon ül a gyerekekkel most 5-ig (...) Tehát nekem mind a kettő kell.” (RI)

A párkapcsolatra építő vándorlástörténet viszont nem csak a nőkre jellemző. Több férfinál is ${ }^{103}$ elsődleges okként jön elő, amihez karrier vagy más jóléti indok is társul.

\footnotetext{
101 Az erdélyi potenciális migránsok vizsgálata kapcsán megállapított egyik kulcs motiváció - a státusvesztéstől, lecsúszástól való félelem - nyer megerősítést (lásd a 4.3. alfejezetet).

${ }^{102} \mathrm{Az}$ erdélyi magyarok normavilága elítélte és elítéli az elvándorlást (Gödri 1998; Kovács \& Melegh 2001). Ezt támasztják alá ezek az interjúk is.

${ }^{103}$ A négy férfi közül három esetében. E háromból kettő tartozik ehhez a típushoz.
} 
BA elbeszélését átszövi a migrációhoz füzött beváltatlan remények és a kudarcélmények dacára mégis „sikeres migráns” imidzsének fenntartására irányuló erőfeszítésből származó feszültség. A döntés felelősségét egymaga hordozza, így fontossá válik annak helyességének legitimálása; illetve a döntéshelyzetben felmerülő elvárások meg a vándorlás utáni élmények közötti kognitív disszonancia (Festinger 2000) csökkentése. Ezt a vándorlástörténete egyediségének, majd döntései megbánhatatlanságának hangsúlyozásával és ismételgetésével próbálja megvalósítani.

Ez a narratíva is azt igazolja, hogy a vándorlás nem annyira egyéni, mint inkább családi stratégia. Ezen kívül fontos eleme a Kelet-Nyugat ellentétpár (Kovács \& Melegh 2001), a kettő közötti egyenlőtlenségek, hierarchia kidomborítása.

„Én még az egyetem alatt megnősültem, és a feleségem, ő nem erdélyi származású, magyarországi születésü, úgyhogy azt is mondhatni, hogy részben a család miatt kerültünk ide. De hogy érdekesebb legyen a történet, én elöször Ausztriába költöztem ki. A feleségem ugyanis ott tanult, ott volt még akkor diák, végzös, úgyhogy Y-ban laktunk egy, hát majdnem egy évig, és mivel nem sikerült... közben elvégezte a sulit, és nem találtunk állást, sem én, sem ö, igy jöttünk vissza Magyarországra. (...) És mondhatni, hogy ez tényleg egy jó választás mindenféle szempontból. A gyerekek is szeretik az iskolát, illetve az óvodát. Igazából a munkahely is jó, anyagilag is, mondhatni, hogy meg vagyunk elégedve. Tényleg. Azért érdekes az én esetem, szóval lehet, hogy érdekes, mert én nem Keletről jöttem Nyugatra, hanem Nyugatról jöttem keletre, és nem sok ilyet fogsz te hallani, hogy valaki visszatelepül Ausztriából vagy Angliából vagy egyéb, úgymond fejlettebb országból Magyarországra, és mégis azt mondja, hogy itt nem rossz. Persze, lehetne jobb is, de nem rossz.” Később: „[É]n az életemben semmit nem változtatnék. Tehát, hogyha ugyanezt még egyszer kellene csinálni, én ugyanígy, mindent ugyanígy csinálnék. " (BA, férfi, háziorvos)

A narratíva kezdetén még marginális szerepet játszó, hol explicit, hol meg implicit formában megjelenő jóléti (anyagi gyarapodásra irányuló) motiváció a későbbiekben mindinkább uralja a történetet, illetve a kérdésekre adott válaszokban hangsúlyosan megjelenik.

„Én akkor kicsit kiábrándultam ebböl az egészségügyi hierarchiából, meg a bérekböl, meg az egész, hát, végül is ebböl a rendszerböl, és akkor én úgy gondoltam, hogy tök jó lehetőség, akár a pénzügyi szektorban mozgolódni” Később: „,[H]át igazából untam én, hogy 80-90 ezer forint körüli fizetésem volt. Ennyi. Ez ilyen egyszerü. Nem akartam én 
életem végéig ilyen pénzekért dolgozni. Ügyeltem, most tény és való, ügyeltem, és ilyen havi 6-7-8 ügyelettel kerestem ilyen 130 ezer forintot 2006-ban- 2007-ben. Nem akartam életem végéig 130 ezer forintból élni, hát ez vicc. (...) Úgyhogy azt gondolom, hogy több lábon kell állni, ez a kulcsa mindennek.” (BA)

A továbbiakban fény derül arra, hogy anyagi megfontolásból ideiglenesen pályát vált, amely döntéshez egy újabb migráció párosul a szomszédos Ausztriába. Ám ez a másodszori nekifutás is sikertelennek bizonyul, és ez az újabb kudarc visszatereli eredeti szakterületére, illetve az anyaországba.

„Én szerettem a munkámat, csak zavart az, hogy mindig megmondták, hogy mikor menjek szabadságra, mikor ügyeljek, mikor mit csináljak, hova menjek. Tulajdonképpen rendelkeztek velem, és egyrészt sem anyagilag nem voltam motiválva, munka az volt böven, lehetett tanulni, gyakorlati tapasztalatot szerezni, de se meggazdagodni, se önálló dolgokat megvalósítani nem nagyon lehetett, úgyhogy én azt mondtam, hogy én most itt életem végéig ennyi pénzért ezt igy csináljam? Nem akarok én mindig másoknak, másokhoz alkalmazkodni. Ezért döntöttem a háziorvoslás mellett, mert a magam ura vagyok (...) Bennem van egy kis ilyen vállalkozó vér is.” (BA)

A történet egyik érdekessége, hogy jóllehet házastársához tervezett kiköltözni az elbeszélő, a migráció mégis váratlanul, felkészületlenül érte.

„Az olyan kis nekivágás volt, nem. Ilyen, mint a szegény legény, tudod, a batyut a nyakába, és hamuban sült pogácsával, aztán...” (BA)

A vándorlás váratlanságával és a „,szerencsét próbáló szegény legény” hősével nem csak nála, hanem ZS esetében is találkozunk, aki szintén elsősorban párját említi vándorlásának kiváltó okaként. És bár a vándorlástörténetben legalább ekkora szerep jut egy véletlen találkozásból származó személyes toborzásnak - állásajánlatnak -, ZS képtelen elszakadni a párkapcsolattal indító narrációs mezőtől, és többnyire nem a felelősségteljes, döntéshozó cselekvő, hanem a szerencsét próbáló „,szegény legény” szerepében mesél továbbra is, akivel „megtörténnek” váratlan események.

„Ez egy ilyen nagyon hirtelen jött az egész, mert én a mostani feleségemet akkor ismertem meg, 2004. nyarán, és akkor szintén 2004. nyarán kaptam ezt az ajánlatot is egy idegenvezetés során végül is, egy müemléktemplomban vezettem körbe egy 
magyarországi csapatot, akiröl azt sem tudtam, hogy kik és mik. És akkor így utána így beszélgettünk, hogy akkor mit csinálok, és akkor mondtam, hogy én most végzek az orvosival. Azt mondták, hogy jaj, de jó, ök meg embereket keresnek. És ha esetleg lenne kedvem, akkor jöjjek ki, és majd megbeszéljük. Végül is egyszer, még azon az öszön szabadságra jöttünk ki az akkori barátnömmel, és ha már felajánlották, biztosak voltunk benne, hogy ez csak egy kicsit ilyen protokolláris felajánlás volt, de hát akkor már megkérdezzük, tekintettel arra, hogy ö már fél lábbal kint élt, így aztán, jó, akkor megkérdezzük, vesztenivalónk nincs. Mondták, hogy igen, persze, januártól kezdhetek. Azért nem tudok erröl többet, mert ez igy annyira hirtelen jött és elözetes tervek, mert én végig úgy terveztem, hogy én majd Romániában elvégzem a szakorvosképzést, és majd valahol a Székelyföldön fogok praktizálni. Fogalmam nem volt arról, hogy mit szeretnék csinálni. (...) és igazából a könnyebb utat választom, mert itt már úgymond volt az embernek, ajánlottak egy munkahelyet, lehetett magyarul csinálni a képzést, és miért $n e ?$ ?" (ZS, férfi, szakorvos)

További vándorlást érintő döntését is - néhány évig Angliában vállal orvosként munkát, ingázik a két ország között - ,szerencsét próbálásként” említi, melynek tulajdonképpeni célja az anyagi gyarapodás; mint ahogy a Magyarországra vándorlásában is közvetve szerepet játszottak a román nyelvi problémák.

Ennél a típusnál tehát szorosan összefonódik a szeretett személy követése - avagy a családi viszonyrendszerek meghatározó szerepe - és az anyagi motiváltság, ami a Nyugat- Kelet között fennálló bérkülönbségek verbalizálásában érhető tetten; illetve ezek kihasználására törekszik. Az anyagi jó(bb)létre igyekvés, amelyet ráadásul a relatív depriváció érzése is táplálhat, könnyen egy sodródó létforma kialakulásához vezethet.

„,Tehát én nem közvetlenül Erdélyböl, hanem, mondjuk Ausztria, Nyugatról jöttem Keletre. Úgyhogy végül is mondhatni, hogy a család, meg talán a pénz. Tehát ezt is fel merem vállalni, hogy itt kezdöként nagyobb lehetöségek vannak, illetve jobb az anyagi vonzata, nagyobb a fizetés, mint mondjuk Erdélyben kezdö orvosként” (BA)

„De most már készülünk tovább, átmegyünk a párommal Angliába. Mert most itt is ugyanaz a helyzet: az egészségügyben nem fizetik túl őket, és... bosszantó az a tény, hogy tudja, hogy pl. Angliában kezdö orvosként tízszer annyi a fizetés- tehát a kezdö fizetés-, mint itt. És az a szomorú, hogy itt-mégis tény, hogy 5 év múlva többet adnak és jobb lesz, tehát nem kell legyen rászorulva a hálapénzre meg ilyesmi. De ott megfizetik 
az orvosokat, nincsen hálapénz, normálisan. Na... Én most megint nem akarok menni, de... (nevet) Úgy látszik, hogy mi ilyen vándorló család vagyunk.” (RI)

„,Végleg kiköltözni soha nem akartam, mármint Magyarországról. És akkor elmentem egy ilyen interjúszerüségre, ahol arról volt szó, hogy majd elmondják, hogy miben is áll a kinti munka. Ez körülbelül tíz percben lezajlott, és a nap hátralévő részében egy ilyen felkészitö volt, hogy majd a kinti munkára, a nap végén pedig mindenki olyanfajta szerzödést kapott, amit átnézhetett és aláirhatott. És ettöl kezdve így adott volt a helyzet, meg sokkal jobb fizetés, egy lehetöség arra, hogy az ember az angol nyelvet egy kicsit jobban megtanulja, úgyhogy akkor ezt én bevállaltam. A család, az maradt itthon, és akkor én minden héten egy hét ott, egy hét itthon három évig. Ez olyan 150 repülöutat jelent pontosan oda-vissza, tehát egy oda, egy vissza. Úgyhogy az úgy jó volt egyébként,

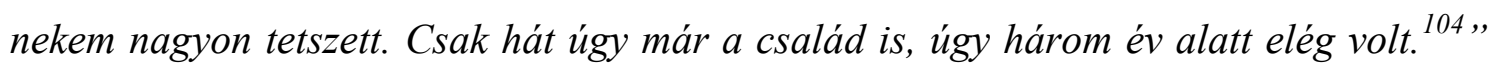
(ZS)

Megállapítható, hogy a családtagok hátrahagyása feszültségforrássá válhat még a gyakori oda-vissza mozgás esetében is. Máskor - mint BA esetében - a nyugatabbi országokban történő munkavállaláshoz füzött várakozások beváltatlan reményeknek bizonyulnak, csalódást szülnek.

„,[O]tt éltünk, és azért mozgolódtunk, és minden szálat megmozgattunk, és azt a következtetést vontuk le, hogy Ausztriában nincs kolbászból a kerités. Lehet, hogy virsliböl van, de kolbászból tuti nincs.” (BA)

\subsection{Karrier orientált migráns}

\subsubsection{Családi-karrier orientált migráns}

Ez a típus abban különbözik a korábbiaktól, hogy a vándorlástörténetben a migráció egyetlen motivációjaként felhozott érzelmi kapcsolat az interjú második felében a háttérbe vesz, majdhogynem eltünik. Egy törést tapasztalható, mintha két különböző személy jelenne meg: míg a narratívában a párját vagy testvérét követő, a másikhoz való viszonyában bemutatott passzív elbeszélő, addig válaszaiban fokozatosan elszakad ettől a szereptől és egy saját karrierjére fókuszáló egyén szólal meg. Az előző típusoktól eltérően, ahol a Nyugat-Kelet ellentétpárban megjelenő makrogazdasági különbségek

\footnotetext{
${ }^{104}$ Csak ideiglenesen hagyta abba a külföldi munkát, tervei között szerepel ismételten az angliai, ingázó munkavállalás.
} 
(elsősorban jövedelmi eltérések) képezték az egyik migrációs motivációt, itt az ErdélyMagyarország szembeállításában az egészségügyi rendszerek különbözőségei (képzési rendszer, felszereltség, szakmai fejlődési lehetőségek) állnak a középpontban.

HR-nek ebbe a típusba való besorolása kicsit problematikus, mivel nem narratív interjúról van szó. Migrációs döntése leginkább a kumulált okság elméletével írható le (Massey 1999): egyik családtagjának előzetes elvándorlása és szakmai motivációk is szerepet játszottak. Jóllehet testvére mintájának követése jelenik meg először - mind a pályaválasztás, mind az elvándorlás terén -, a szakmai megfontolások, a korábbi migrációs tapasztalat és az ennek következtében kialakuló szakmai relatív depriváció motiváló hatása is kezdettől jelen van, más irányból hatva ugyan a migrációs szándékra, de ugyanazt a tervet erősítve. Az ok, amiért mégis ebbe a csoportba került besorolásra, az a vezetői szerep; a későbbiekben kiderül ugyanis, hogy párja vele együtt jött, öt követte. De nagyon kevés esetben szólal meg a „mi”, többnyire csak a jövőt illető terveik kapcsán.

„A növérem- szintén a növérem (nevet), igen nagy szerepet játszott az életemben mindig, amikor nagy döntések elött álltam; ö volt az úttörö, én meg követtem öt mindig. Ök kiköltöztek már... nem tudom, mikor. Már egyetemista voltam, de nem tudom, hányban (...) és nagyon hívtak, hogy próbáljam meg itt kint, egyrészt. Ez volt az érzelmi oldala. Másrészt, szakmai szempontból, azért döntöttem így, vagy azért választottam ezt az utat, mert 6. éven voltam kint majdnem egy hónapot részképzésen itt, a SOTE-n, és hát nagyon megtetszett az egyetem. Éreztem, hogy ég és föld a színvonalbeli különbség.” Később: „Azt tudni kell, hogy nem egy átlagos nívójú rendelöben dolgozom most, egy szakmailag ismert és elismert ember a fönököm, a rendelö vezetöje, akitöl rengeteget tanulunk, tanulok. De ez nem átlagosnak mondható színvonal még P-ben sem. Tehát nagyon nagy szerencsém volt igazából... de én is a kovácsa voltam egy kicsit ennek a szerencsének, mert nem itt kezdtem.” Férjéről beszélve pedig: „Ö sosem akart eljönni, csak miattam jött el (nevet), engem követett, de most viszont neki is nagy szerepe van abban, hogy még mindig itt vagyunk. Mert miután én leszakvizsgáztam, mondtam, hogy részemröl vehetjük a sátorfánkat, és mehetünk haza; viszont akkor már ö volt szakmailag egy olyan helyzetben, egy olyan lehetöség elött állt, amit nem akart kihagyni, és akkor így évröl évre húzódott ez a dolog. ” (HR, nő, fogorvos)

A korábbi típustól eltérően, ezek a karrier-centrikus elbeszélésmódot választó nők a továbbvándorlás ellenében a helyben maradást vagy visszatérést tervezik. Jóllehet férjük terveiben szerepel(t) a nyugatabbra vándorlás, ök ezt a tervet - férjükkel közös 
megegyezés alapján vagy egyénileg szembehelyezkedve - elutasítják, a magyar társadalomba való sikeres integrációjukra („,meggyökerezés”), a kulturális és földrajzi közelségre, illetve távolságra hivatkozva. A kibocsátó országhoz való földrajzi közelség azért fontos, mert egyfelől segíti a szülőföldhöz füződő kapcsolatok intenzív ápolását, ${ }^{105}$ másfelől a visszatérési szándék életben tartását szolgálja. ${ }^{106}$

MJ is nagyon rövid elbeszélést nyújt arról, hogy hogyan, pontosabban miért vándorolt Magyarországra, amit így összegez:

„Lényegében utána [mármint a barátja] jöttem, úgy kerültem ide.” (MJ, nő, orvos)

Tehát párkapcsolatára hivatkozva legitimizálja döntését, amely egy mintakövető stratégiához vezet. Viszont a részletekre irányított kérdésekre válaszolva a saját karrier bemutatása kerül elő. A sodródás itt is jelen van, de csak országhatárokon belül, szakmai okokból (saját szakképzése, férje karrierje kapcsán). Kifejtéseiben férje karrierjének elmesélése csak ritkán keresztezi az övét, és ilyenkor vált át többes számba.

„,És ügyeltem is már, akkor is csak úgy, hogy ott volt mellettem a föorvosnö. De ez ugye nekem egy kicsit, hogy is mondjam, tekervényes a történet, mert júliusban járt le az én szerződésem, és akkor 2007-ben volt egy ilyen létszámstop az egészségügyben, hogy azt mondták, hogy több új alkalmazottat nem vesznek föl, és a Y-i kórház emiatt nem adott nekem szerzödést, és pont a férjemnek is letelt a rezidensi időszaka, ami ugye azt a két évet jelenti, amíg az egyetemmel vagy szerzödésben, amíg az egyetem fizet, és a két év után a másik négyet, mert ö sebész, neki hat év kellett, azt a másik négy évet, azt már a kórház kell, hogy fizesse a béredet, meg a szakképzéshez ő enged el utána. És akkor neki meg az kellett volna, hogy a kórház alkalmazásba vegye, és így akkor a férjemet sem vették alkalmazásba, és nekem sem adtak tovább szerzödést. És akkor emiatt elkerültünk K-ba, mert ott volt sebész állás. ” (MJ)

A narratíva, majd a válaszokból kirajzolódó történet ambivalenciájának oka lehet, hogy a saját szakmai és egyéb indokaikra (román nyelv használata, országok közötti makro különbségek: az elérhető bérek, a képzési rendszerek különbözőségei) hivatkozva önzőnek tűnhetnek és ezért valami „erősebbel” (Kovács \& Melegh 2007), rokoni vagy párkapcsolatra, esetenként etnikai okokra alapozva legitimálják döntésüket.

\footnotetext{
${ }^{105}$ Elsősorban a határmenti területekről áttelepültek esetében tölti be ezt a funkciót.

${ }^{106}$ Ezt a következő típushoz tartozó NE még egyértelmübben verbalizálja: ,,minél messzebbre megy az ember, annál nehezebb utána megvalósítani” a visszatérést.
} 
„Hát, most mit mondjak? Sokkal egyszerübb anyanyelven beszélni a betegekkel, még akkor is, hogyha az ember megtanul románul, de mégsem úgy fejezi ki magát az ember, minthogyha az anyanyelvén beszélne (...) A nyelvi könnyebbség, meg az, hogy itt igazából sokkal könnyebb volt bekerülni a rezidensi rendszerbe, nem úgy, mint Romániában. (...) Meg hát, ugye a körülmények is akkor jobbak voltak, mint Romániában, a kórházi körülményekre értem ezt az egészet. A fizetés is jobb volt, mint Romániában, de most már azt kell mondanom, hogy sem a fizetés, sem a körülmények nem annyival jobbak, mint amennyivel anno voltak.” (MJ)

Az RT által elmesélt történet alapjában nem különbözik az előzőektől: a nővére példáját követő nő ${ }^{107}$ számára a Magyarországra vándorlás a „nagy álommá” válik, melynek alapja a szoros testvéri kapcsolat. ${ }^{108}$

„Hát ez álmom volt már amikor az egyetemre jártam, hogy-a növérem már kikerült, és 5 év van közöttünk, de nagyon-nagyon szoros a kapcsolat- hogy jövök utána. Tehát ez ilyen (nevet)... Végül is emiatt... emiatt akartam kijönni. És már csak annyi volt hátra, hogy legyen meg a diploma, és válasszak valami olyat, ami tetszik. Az egyértelmü volt, hogy én is A-ba kerülök, tehát én is ott kezdek” Máshol: „És ez már ilyen bolondosan beteljesülés volt, hogy ide jöttem és akkor OK, most már együtt vagyunk, és akkor a szüleink is megnyugodtak, hogy ott vagyunk egymásnak. Ha már nem mellettük, akkor legalább egymásnak ott vagyunk.” (RT, nő, szakorvos)

Viszont ezt a kezdetben bemutatott, kerek történetet,- amely valószínüleg a családban többszörösen átbeszélt és legitimként elfogadott naratíva - a későbbiekben számos meglepő, ennek „ellentmondó” esemény követi, ami terhessé, feszültté teszi az összképet. A továbbiakban többnyire egy aktív szereplőként bemutatott cselekvő jelenik meg, aki döntéseiben és párkapcsolatában is függetlenként, egyenrangúként jeleníti meg magát. Migrációs döntésének alárendelődik a párkapcsolati stratégiája.

„Harmadévesek voltunk. Tehát ő [mostani férje] már úgy ismert meg, hogy az volt a vágyam, hogy eljöjjek. És eljött az a pillanat, hogy befejeztük az egyetemet, éppen jött a nyár. Ö már egy évvel elöbb befejezte, de K-ban maradt, és... eljött a pillanat, amikor...

\footnotetext{
${ }^{107}$ Ez a mintakövetés csak a migrációra terjed ki. Jóllehet az idősebb testvér is orvos, RT nem őmiatta választja ezt a pályát.

${ }^{108}$ Narratíváját befolyásoló tényező lehet az, hogy nővére adta meg az elérhetőségét; ő egyeztetett vele elözetesen az interjú ügyében.
} 
talán mondhatta volna azt, hogy ne menjek, de talán úgy gondolta, hogy ha ez az én álmom, akkor nem áll elé. És mivel ezt nem is mondta, akkor dacból is, vagy nem tudom... tehát ez volt a... ez volt megírva, hogy el kellett jöjjek. Aztán azóta egy csomót szenvedtünk, mert 10 éve vagyunk együtt, tavaly házasodtunk csak, és... ez nagyon hosszú ideig csak távkapcsolat volt (...) ö nem jött ki. K-ban dolgozik, ezért lakunk mi Cben, ez pont a félút. Elövettük a térképet, megnéztük, hogy mi a közepe ennek a $K-B$ útnak, és akkor C-ben van egy utca, amelyik ott vezet át (nevet) a közepén, és akkor mindenki 35 km-t megy be dolgozni, és 35 km-t, mikor haza megy.” (RT)

Az aktív-passzív beszédmód közötti váltások és az abból eredő ellentmondás a döntés legitimálásának - jelen esetben a helyben maradásé a visszatéréssel szemben problematikusságát hozza felszínre: az elbeszélő mintha maga sem értené meg önmagát.

„[V]alószínüleg lett volna lehetöségem, hogy visszamenjek, és nem... nem tudok már visszamenni. Barátaim ott vannak, barátaim ott dolgoznak, férjem ott dolgozik, ugyanaz a kórház végül is, ahol dolgozik, egy helyen dolgoznánk mind a ketten, nekünk ott van lakásunk 5 percre az új sugárterápiától, és mégsem érzem úgy, hogy vissza tudnák menni (...) Ez ilyen nagy-nagy visszalépés lenne [szakmailag], ha visszamennék, és nem hiszem, hogy tudnák adaptálódni az új környezethez, adjunktúrához." Egy másik történetben: „Akkor, amikor mehettünk volna, Németország volt, aki fogadott, egész könnyen lehetett ott honositani, meg hát egyáltalán... Nem tudtam volna ott maradni. De tényleg, mikor ott voltunk minden, az anyagi része is nagyon jó volt, igy ösztöndíjas... volt szállásunk, volt az étel, a hétvégén a bicikli, kaptunk 400 eurót; tehát az nagyonnagyon sok volt nekem, mint egyetemista, és mégis annyira boldogtalan voltam, hogy... nem voltam ott 6 hónapot, utolsó hónapban igy ikszeltem a naptáramban a napokat, mint a börtöntöltelék, hogy jó, ennek is vége lett. Pedig a legjobb barátnöimmel laktam egy albérletben, egy órás út volt a másik város, ahol ö lakott.” (RT)

\subsubsection{Egyéni- karrier orientált migráns}

\subsubsection{Hezitáló narratíva}

Ebbe a típusba mindössze két vándorlástörténet tartozik. Több ponton kapcsolódik az előbbi típusokhoz, mint például a romániai egészségügyi rendszer - és benne föként a rezidensképzés- bírálata, a korábbi migrációs tapasztalat, illetve akár a Nyugat-Kelet ellentétpárban a haszonkalkuláció említése. Ami viszont megkülönbözteti, az az, hogy mindkét narratíva inkább a karrierre összpontosít, az emberi kapcsolatoknak nincs 
igazán jelentős szerepe benne. Mivel párkapcsolat egyáltalán nem említtetik a vándorlástörténetben - sem előtte, sem utána -, az elbeszélés teljesen a szakmai pálya bemutatására épül. Egy további sajátos jellemzője ennek a típusnak, hogy egy belső feszültség szövi át. Az elbeszélésből vagy hiányzik a személyes döntéshozás eleme (az erre utaló igék) vagy a migráció egy külső adottságként, illetve a körülmények kényszereként jelenik meg.

NE esetében ez a feszültség már az indítás pillanatától jelen van, amikor két narratívát is felkínál.

„Hát úgy kerültem ide, hogy... az öszinte verzió vagy a hivatalos?” (NE, nő, orvos)

Az „őszinte” verzió az egyetemi professzorok közötti konfliktusról számol be, amely közvetve őrá is kihat és szakmai terveinek módosulását eredményezi.

„,Mert nekem ugye eszem ágában sem volt eljönni, tehát ez a vicces a történetben, csak aztán (...) akkor ez volt az, ami végsö soron eldöntötte, de... Tehát ez a nem hivatalos verzió." (NE)

Itt az ellentmondás a kétféle narratíva szereplője között feszül, hiszen a különböző motivációk és döntési mechanizmusok eltérő kilépési módokat és ezzel együtt eltérő identitásokat eredményeznek (Biró 1996): egyfelől a szülőföldi szakmai lehetőségeitől megfosztott friss diplomásból az alkalmi „kényszer” migránsét, másfelől a toborzott, a szakmai álmait követő és a migrációt előkészítő vándorét. Az elbeszélő a kettő között váltogatva mesél, általában tudatosan jelezve azt, hogy most éppen melyik szálon fut a történet. Ebben az elbeszélésben is - akárcsak ZS esetében - a döntést egy váratlan és páratlanul kedvező, kihagyhatatlannak tünő lehetőség, pontosabban az azzal való élés legitimizálja. ${ }^{109}$

„És akkor mondta a prof., hogy ha akarok, akkor jöhetek PhD. hallgatónak, és akkor így nekem... hát, elég sokáig, úgy 6. év elejéig azt mondtam, hogy nem, és akkor... mert hát ugye, itt az is volt, hogy ahhoz kellett egy ösztöndijat is szerezni, hogy az ember ne épp ingyen éljen és viruljon, és... megpályáztam egy ösztöndíjat, ez az NSD-nek ${ }^{110}$ volt, amit ugye Romániában 4 embernek osztották ki, úgyhogy én ehhez olyan nagyon nagy

109 Jóllehet NE aktívabban részt vesz ennek a lehetőségnek az előkészítésében, míg ZS esetében csakugyan ,véletlenről” van szó.

${ }^{110}$ Álnév. 
reményeket nem is füztem, és aztán végül is én lettem az egyik abban az évben abból a 4 emberböl... végül is igy vált lehetövé. Én egyébként... tehát utána jött az, hogy összebalhéztam XY-nal, tehát ez még mindig úgy volt, hogy nem volt teljesen biztos- ez most megint a nem hivatalos verzió. De végül is így, hogy volt egy ösztöndijjam, volt egy prof., aki készséggel várt és volt egy olyan terület, amit szerettem volna is csinálni, és szerettem volna kipróbálni, hogy milyen is az a kutatás, tehát milyen az, hogy laborban dolgozni, ténylegesen kutatni, nem csak kórlapokat bújni, amit az egyetemen is csináltam. Tehát végül is így kerültem én ide.” (NE)

A narratíva egy további sajátossága, hogy többnyire hiányoznak a vándorlásra utaló igék, az elbeszélő ilyenkor az aktív cselekvőből passzív elszenvedőjévé válik annak, amit a külső történések ,rákényszerítenek” vagy amit szerencséjének köszönhet. Mindezek együttesen utalnak arra, hogy a migráció számára sem teljesen elfogadott. Ezt támasztják alá a szülőföldhöz való erős kötődés, a visszatérés szándéka, a saját népén való segíteni akarás, illetve az őt feltételesen elengedő és visszaváró szülő.

„[A]zért, mert úgy érzem, hogy... hogy ezzel, amit választottam otthon elég sokat tudnék segíteni, mert ez otthon elég gyerekcipöben jár ez a tudomány, és hát igazából akik foglalkoznak vele, azok sem mind értenek nagyon hozzá. (... És hogy ezt otthon egy kicsit megpróbálni használni; bár egy fecske nem csinál tavaszt”. ${ }^{111}$ Később: „És én... én otthon szeretnék... pont azért mert... egy olyan helyen, ahol... ahova emlékek kötnek, ahol az emberekkel így még... mondjuk találkozhatok ismerösökkel az utcán, tehát így ez... Ezért inkább otthon... De mindenképpen olyan területen, ahol magyarul beszélnek.” Máshol: „[M]ind a ketten támogattak, apum maximálisan, anyum meg azzal a feltétellel, hogy aztán legyek szives és jöjjek haza egy idö múlva. De mind a ketten támogattak, és apum mindig azt mondja, hogy söt még messzebbre, hogy ha kell és hogy... otthon annyira rossz most a helyzet, hogy meg se forduljon a fejemben haza menni." (NE)

\footnotetext{
${ }^{111}$ A külföldön megszerzett szakmai tudásfölény otthoni kamatoztatása néhány más interjúkban is előjött, azokban viszont nem a segítségnyújtás, hanem a saját anyagi gyarapodás áll a háttérben. Illetve szakmai okokra hivatkozva utasítják el némelyek a visszatérést, mivel az számukra visszalépést jelentene. Ez utóbbi a 'brain circulation' jelenség működésének korlátozottságát támasztja alá (Favell et al. 2008).
} 
A visszatérés gátló tényezőjeként megjelenik a kedvezőtlen román társadalmi-gazdasági helyzet, a korrupció, az egészségügyi rendszer fejlödésének hiánya és a rossz munkakörülmények: ${ }^{112}$

„[N]em csak orvosként igazából, hanem szinte bármilyen szempontból nem túl szívderitö most a helyzet, és tényleg ezen valamit változtatni kell, mert nem kellene ilyen rosszul álljanak... az ország, mint ahogy áll. Kicsit kevesebbet kéne lopni és akkor kicsit több jutna az embereknek a megélhetésére és jólétére. Tehát amikor... most is hallottam otthon, hogy a daganatos betegeknek a gyógyszert behozzák az országba, csak még mielött kiküldenék a centrumokból, hogy megkaphassa a beteg, azelött eladják jóval drágábban, nem hivatalosan külföldre, és akkor a beteg meg nem kapja meg. És mondják a betegnek, hogy de hát ha meg akarja kapni azt, ami megmenthetné az életétmég így se biztos, de nagyobb valószínüséggel-, akkor hozassa be, tehát vegye meg magának. Ezekre én nem találok szavakat, tényleg... Döbbenet. Úgyhogy... tényleg, ami most otthon van, tehát...uhh... tényleg kritikán aluli. És egyszer ezt már végigasszisztáltam a gyerek... a daganatos betegekkel. És az ezelött 7 évvel volt, és most se változott semmi.",113 (NE)

AO történetében a feszültség forrása egyfajta frusztráció, a pályát módosított férfi saját döntéseinek helyességét kérdőjelezi meg utólagosan. Bár elbeszélésmódja többnyire individuális, szenvtelen, szűkszavú és racionális, mégis egyfajta passzivitás, közömbösség jellemzi (Kovács \& Melegh 2004).

„Az utolsó egy-két évben az egyetemen ez már egy eldöntött dolog volt, hogy valahol külföldön vállalok munkát. Németország vagy a német nyelvterületek alapvetően, és Magyarország jött így szóba.” Később: „Egyszerüen csak úgy döntöttem, hogy miután megkaptam a diplomámat, hogy eljövök Magyarországra. Nagyon-nagyon nem érdeklödtem, nem érdekelt, hogy hogyan fog menni az egész folyamat. És az pedig úgy

\footnotetext{
${ }^{112}$ Hasonló okokra hivatkozva érvel a visszatérés ellen az előző típusba besorolt RT is: „,[H]ogy milyen kondíciók vannak- most a kondíciót nem a falakra és a bútorra értem, hanem... hanem, hogy milyen lehetöségeik vannak a betegeknek. Ha nincs pénze kifizetni a vizsgálatokat, ha nincs pénze kifizetni a mellékhatásoknak a kezeléséhez a gyógyszereket, vagy sokszor még a citasztatikumot (?) is saját zsebböl kell állja, akkor... akkor nincs mivel dolgozni sem. Hát nálunk a CT, az MR, a fej CT az... felveszem a telefont, beirom a gépbe, és akkor egy hét múlva- két hét múlva rendelkezésemre áll. És akkor egy pontosabb tervezést és egy pontosabb kezelést tudok végrehajtani(...) Persze itt is sírunk és állandóan jobb felé tendál az ember, de... nem tudnák már visszamenni."

${ }_{113} \mathrm{Az}$ orvosmigráció kutatása kapcsán mások is hasonló következtetésekre jutottak: a taszító tényezőkként müködő körülmények (mint a korrupció, a kibocsátó és befogadó ország egészségügyi technológiája és felszerelése közötti eltérés) javulásának hiánya következtében nincs visszavándorlás. Néhány ország tapasztalata szerint a feltételek javulásával megindul a visszavándorlás (Packer et al. 2010).
} 
idöközben kialakult, hiszen annak idején még a Bevándorlási Hivataltól kellett tartózkodási engedélyt kérni, vagy munkavállalásit, vagy nem tudom, micsodát, és akkor egyik folyamat a másikat követte, és mindig szóltak, hogy mit kell csinálni következö lépésként." (AO, férfi, gyógyszerügynök)

A korábban említett belső bizonytalanság más események kapcsán is megjelenik mint például a pályaválasztás. Ez utóbbi esetében a mintakövetés vezérli a döntéshozást.

„Érettségi után felvételiztem az orvosira, habár nem voltam biztos benne, hogy orvos akarok lenni. Ez már akkor is olyan necces volt, hogy most milyen szakmát válasszak magamnak. (...) Tizenkettedikben, persze. Hát így megkérdezte az osztályfönök, hogy ki hová megy. Többen jelentkeztek, hogy orvosira, hát, mondom, akkor én is oda megyek. Most semmi nagy affinitást nem éreztem különben ebbe az irányba, nekem teljesen mindegy volt." (AO)

Belső vívódását, a döntési folyamat nyitottságát, a nyugati jólét keresését (a KeletNyugat ellentétpár említése révén) jól tükrözik alábbi válaszai:

„Közben voltam Németországban is egy ideig gyakornok, három hónapot. Már bánom, hogy visszajöttem, mert akkor mondták, hogy maradjak ott, de úgy gondoltam, hogy itt jobbak lesznek a lehetőségek, vagy legalábbis akkor még úgy tünt, hogy sikerül a kórház vezetésével megegyezni. Mondjuk, az hiba volt, tehát akkor, abban a pillanatban kint maradhattam volna.” Máshol: „Minden más valószínüleg jobb választás lett volna. Tehát Nyugat-Európa, az mindenképpen jobb választás lett volna, mint Magyarország, már annak idején. Ezt nem bánom, hiszen itt is a maximumot, amit ki lehetett hozni, azt szerintem megtettem vagy megteszem, de az biztos, hogy elönyösebb lett volna anyagi szempontból, szakmailag és munkahely szempontjából viszont valószinü, hogy nem. Tehát ott sokkal nehezebb érvényesülni, én úgy gondolom. ” (AO)

A feszültség egy további forrása lehet a szüleivel való konfliktus, pontosabban a szülei elutasító attitűdje a migrációjához, amely az erdélyi normavilágot közvetíti:

„,Most sem tudják elfogadni, ez egy alapprobléma, komoly konfliktushelyzet különben. Ök nagyon ritkán, egy évben egy-két alkalommal eljönnek Magyarországra. Én nagyon gyakran nem tudok hazamenni, és akkor ez már önmagában egy feszültségforrás, hiszen lehetnék ott folyamatosan valahol a közelükben, és az sem jó indok számukra, hogy, 
mondjuk, akár Erdélyen belül, Románián belül már nem is beszélve sokkal nagyobb távolságra lehetnék tölük, mint most. Most három óra alatt autópályán otthon vagyok. Ugyanezt a három órát tudom menni vagy négy órát Magyarországon belül, és még sehol nem vagyok, ha nem autópályán megyek." (AO)

Beváltatlan reményeire a megoldást a továbbvándorlásban látja.

\subsubsection{Nem hezitáló narratíva}

Hiányzik az előző típus narratívájára jellemző feszültség. A vándorlástörténetben ha meg is jelenik a párkapcsolat, a másik fél - esetleg gyerek - csak marginális szerepet játszik. Bár különböző okok vezettek a Magyarországra vándorláshoz, szakmailag sikerült megvalósítania célját, elérnie valamit.

TC elbeszélésében az odahaza megélt „szakmai zsákutca”, a kilátástalannak ítélt karrier vezet el a migrációs döntéséhez. Terve megvalósításának első lépésében rokoni migráns kapcsolatára támaszkodik, illetve ez befolyásolja a célterület kiválasztását. Úgy meséli el a történetét, hogy annak ő az egyedüli cselekvője, aki egymaga elindul, állást keres és intézkedik mindaddig, amíg célját eléri.

„,Ott nem sikerült akkor nekem, gyerekgyógyász szerettem volna lenni, de nem sikerült, mert elég magas pontszámok kellettek volna hozzá. Otthon voltam B-ben stagiar [gyakornok], nagyon szerettem ott lenni, és tényleg jó volt ott... úgy tünt, hogy akkor ott szeretnék maradni, de aztán nem nagyon biztattak ott a B-i klinikán, és a rezidens képzést, azt nagyon magas pontszámmal - olyan 800-900-as pontszám kellett volna, és nekem nem jött volna össze szerintem másik évben sem (...) És utána eldöntöttem, a nagynéném C-ben lakott, hogy megpróbálom Magyarországot. És C-ben ajánlották a patológiát; mondtam, hogy köszönöm szépen, ez nem az én lelkivilágomnak - tudod, hogy gyerekgyógyász lelkivilágának nem megfelelö (nevet). És akkor ajánlották, hogy A-ban vannak helyek, próbáljam meg. El is mentem A-ba” (TC, nö, szakorvos)

Individuális cselekvő szerepét a későbbiekben is igyekszik megőrizni, amikor válaszaiból kiderül, hogy a kiindulópontot a migráció tervezésében egy kolléga „győzködésének”, személyes toborzásának az eredménye (Sassen 2007), illetve párjával egyidőben vándorolt az anyaországba.

„És ő [kolléga] mondta, hogy ö elmegy Magyarországra, kész, öt nem érdekli. Ő mind mondta, hogy te T, miért vagy ilyen butus, gyere te is. De mondom, hogy: P, te tudsz 
valamit, hogy mit kell ott csinálni? Hát persze, megyünk és elintézzük. És annyira természetesnek vette, hogy megyünk Magyarországra. Nekem nem volt, nem lett volna ez ilyen kézenfekvő. És akkor vele csak néhány hónapot voltunk együtt, de ö nagyon kis kommunikativ, nagyon-nagyon közlékeny és aranyos lány volt; és igy beültette a fejembe valahogy a bogarat, és valahogy nem ment ki utána a fejemböl. Ö nem segített semmiben, hogy mit kell intézni vagy mit nem kell intézni, hanem én tényleg elmentem elöbb a nagynénémhez C-be” Máshol: „,[K]özben kapott [párja] egy Ph.D. lehetöséget itt G-ben, úgyhogy kapott az alkalmon és jött. De közben nekem is rendezödtek ezek a dolgok, úgyhogy így szinte párhuzamosan jöttünk, de függetlenül egymástól, tehát nem volt az, hogy na, ha az egyik eljön, akkor a másik is eljön. Ez mind a kettönknek így generálódott, valahogy a sors így hozta.” (TC)

Gyerekorvosi álmát az anyaországban sem könnyü megvalósítania, a ,járatlan úton” való próbálkozás az adminisztráció útvesztőjében kudarcba fullad, ami a már ismert útra, a honfitársi migráns tömbbe tereli:

„,[D] ott segitettek mindent elintézni. Már ott ki volt járva az út, és nagyon könnyedén tudták intézni ezt az egészet. Ez jó volt, hogy nem kellett ilyen akadályokba ütközni. Mert például elmentem G-be is, mert ott ajánlottak nekem gyerekgyógyász állást, csak ottan mindenféle bonyolult... azt hitték, hogy milyen bonyolult ez az egész. Nem volt kijáratva ez az út, és nem szívesen láttak. Természetesen az osztályon szívesen láttak, de már ezeket az adminisztratív dolgokat a humánpolitikai osztály nem szívesen vette, hogy most ezeket akkor intézze. Igazából nem kellett volna olyan sok mindent intézni, csak nem tudták, hogy hová, mit kell.” (TC)

A nagy történetben egy alkalommal itt is megjelenik a belső konfliktus. Jóllehet a kezdő narratív részben nyomát sem találni, a migrációs döntés sikerességét értékelve előjön a szülők iránt érzett felelősségérzet és a lelkiismeret furdalás. ${ }^{114}$ Ennél a résznél a nála nagyon ritkán használt többesszámba vált át, mint aki párjával osztozik ennek a felelősségnek a hordozásában.

\footnotetext{
${ }^{114}$ Ez azonban abban különbözik a korábbi bevándorlók esetében megfigyelt, a migrációt elítélő kultúrából eredő lelkiismeret furdalástól (Kovács \& Melegh 2001), hogy itt nem a tágabb közösségi tagok (honfitársak) cserbenhagyásából származik, hanem egy mikroközösséggel (család/szülők) szemben vállalt kötelezettség be nem teljesítéséből. Ez individualizálódó életvezetésrőll és gondolkodásmódról tanúskodik (Bodó 2008).
} 
„Az nagyon rossz, hogy a szüleim otthon vannak, és hogy otthagytam öket. Kétségekkel vagyok tele, hogy ez jó... vagy legalábbis nem ilyen messzi kellett volna eljönni (...) És ez nagyon rossz érzést kelt bennünk, mert hogy egyszerüen nem számíthatnak ránk szegények. És ez nekem borzasztóan rosszul esik, hogy vagyunk nekik, de mégsem; mikor baj van, akkor nem vagyunk ott, és ez rossz érzés. Ha még egyszer... igy hozta a sors." (TC)

\subsection{Etnikai migráns}

Az erdélyi magyar identitásnak egyik kulcseleme a többségi nemzettől való megkülönböztetés. A másságban való szocializálódásuk lényege, hogy a társadalmi másiktól való megkülönböztetésben határozzák meg magukat (M. E. Szakáts 1995). Ezt a különbözőséget egyaránt hangsúlyozták a román és az erdélyi magyar nacionalista ideológiák, illetve a magyarországi politikai diskurzusok is támogatták (Fox 2003; Gödri 1998). Az etnicitás, a kisebbségi léthelyzet fontos és nagy magyarázóerővel bíró tényezője volt az erdélyi magyarság kivándorlásában (Brubaker et al. 2006; Sandu 2000a; M. E. Szakáts 1995; Kovács \& Melegh 2001; Gödri 2010), főként a rendszerváltást megelőző és követő időszakban.

\subsubsection{Etnikai-karrier orientált narratíva}

EP története a migrációt olyan stratégiaként mutatja be, amely segített elhagyni a számára nemkívánatos nyelvi környezetet, az elutasított kisebbségi léthelyzetet (Feischmidt \& Zakariás 2010; Gödri 2010). Elbeszélésében egy csoportos vándorlást, mintakövető történetet ír le, és későbbi válaszaiban is sürün váltogat a többes szám általában mikor itt megélt eseményekről, tapasztalatokról mesél - és az egyes szám között. A készenléti, várakozó állapotból egy váratlan találkozás - személyes toborzás mozdítja ki, amely mobilizálja migrációs szándékát.

„,[H]át voltunk 13-an, akik mindenképpen menni akartunk úgy valamerre- már itt dolgozott kint XY, aki egy elözö évfolyamon végzett, és csak véletlenül összefutottunk az utcán, megkérdezte: nincs kedved, de, van kedvünk. És akkor kijöttünk, szétnéztünk, tetszett úgy a hely, ahogy fogadtak... s azóta itt dolgozunk. Mondjuk maradtunk a 13-ból hárman, mert a többiek mind visszamentek.” Máshol: „,Nem neveltek román ellenesnek, de úgy legbelülröl tiltakozik minden egyes porcikám az ellen, hogy románul beszéljek, és hát oda kellett. Alig vártam, hogy a sulit elvégezzem és ne kelljen többet románul 
tanulni. Úgyhogy igazából csak ez volt úgy az indítóok, hogy mondtam, hogy bármilyen nyelvet tanulok, de azt nem (...) [A]hogy letettem az államvizsgát és mondom, hogy volt ez a kapcsolat, egy percig nem gondolkodtam. Tehát nem az volt, hogy akkor megrágom, átrágom, tervezem, hanem döntöttem és jöttem." (EP, nő, nővér)

Viszont későbbi önbemutatása: „,Utána meg itt építgettem szépen a karrieremet”, „De már akkor is bennem volt, hogy már szeretnék megállni a saját lábamon és nem az, hogy hátulról támogassanak. Azóta meg már nagyon büszke... büszke volt rám”, „A hozzátartozó az úgy kezeli, mint akár egy szobalányt, akinek pattogtat (közben csettint is az ujjával), aztán se kérem, se köszönöm. Mondjuk ilyen téren én nagyon nevelem öket. Még azt se hallom, akár a betegtöl is, ha úgy kéri, biztos, hogy nem. Kéremköszönöm, ez a varázsszó nálam”, elért pozíciója (osztályos főnővér), a visszavándorolt kollégái mindegyikével való közvetlen kapcsolattartás arra engednek következtetni, hogy a többes szám használata inkább egy vezetői szerepet jeleznek, illetve az elbeszélő egy olyan pozíciót vesz fel, amelyben ő az egész csoport képviselője és szóvivője. Ezt a vezetői szerepet támasztja alá a férjéhez való viszonya is. A történetben nem sok hely jut párjának, amit részben magyaráz az, hogy már idekint ismerte meg öt, illetve magyarországi származású. Viszont ő az egyedüli nő az interjúalanyok között, aki bár férjezett, mégis a jövőt illető terveiről és szándékairól egyes számban beszél; férjét vagy annak terveit nem is említve.

Az integráció hiányának ad hangot, amely valószínűleg a származási családjához füződő kapcsolatai és kollegiális kapcsolathálózatának leépüléséből - honfitársai visszavándorlása következtében - adódik. Ez az állapot vezet a sodródáshoz: a továbbvándorlás, esetleg visszavándorlás fontolgatásához.

„Itt azért az ember, ha belegondol, akárhonnan nézi, egyedül van.” Később: „,Mert itt vagy dolgozol és van pénzed, és nincs idöd regenerálódni, vagy nem dolgozol, akkor meg a sárga csekket nincs, aki kifizesse (...) Itt azt hiányolom, hogy az ember dolgozik 30 napból 30-at, és akkor tényleg van mindenre, de hát nincs szabadidöd. És ez hosszú távon nem jó.” Máshol: „[A] helyhez én sem nagyon ragaszkodok, nem tudom megmagyarázni, hogy miért. Itt is szeretem, de most, hogy otthon voltam, mondom simán, egyik napról a másikra képes lennék hazaköltözni, és egy percet nem gondolkoznék azon, hogy bánnám. Úgyhogy benne van a pakliban, hogy egy nap azt mondom, hogy jó, hát akkor megpróbálom máshol." (EP) 
Az elvágyódás- visszavágyódás kettősségére, mely minden vándorlástörténetben tetten érhető (Kovács \& Melegh 2004), tudatosan is reflektál, verbalizálja mind a saját tapasztalataiból, mind migráns rokonának tapasztalatából merítve.

„Nem mondom azt, hogy nincs honvágyam, mert szerintem hazudik, aki azt mondja, hogy nincs. Vannak olyan idöszakok, amikor az ember rágódik és úgy végiggondolja, hogy mi lett volna, ha... Szerintem ez mindenkiben megfordul, aki otthon maradt, és soha nem lépett $k i, a z$ is biztos eljátszik a gondolattal, hogy mi lett volna, ha megpróbálja...” Máshol: „,[Ö]benne alakult ki az a kettősség, ami szerintem elöbbutóbb mindenkiben kialakul. Azt mondta, hogy amikor valaki valamilyen idegen országba akar menni, nagyon-nagyon mérlegelni kell azt, hogy soha többet nem lesz már ugyanaz az ember. Ö nagyon honvágyas. Most van ott, hogy hát ilyen heti szinten elsírja magát, hogy de haza akar költözni, de aztán mégse akar haza költözni... Pedig ök jól élnek. Tehát még csak az sincs, hogy-tényleg nagyon jó nyugdija van, meg megtalálta ott a maga szerencséjét. Ettöl függetlenül benne van a kis... marcangoló."

\subsubsection{Diszkriminációs narrativa}

Egyetlen migrációs történet tartozik ebbe a kategóriába. Jóllehet nem a szó szoros értelmében vett narratív interjúról van szó, mégis a többi narratívához hasonlóan került elemezésre, mivel az első kérdést követően,-- melyben családi hátteréről, tanulmányairól kérdeztem - önként mesélte tovább a történetet, egészen Magyarországra érkezéséig.

GL lényegében egy diszkriminációs történetet mesél el, amelyben az őt - etnikai alapon - ért hátrányos megkülönböztetések, szakmai karrierjének akadályoztatása, választási lehetőségeinek korlátozása és kényszerpályák hatására dönt végül a Magyarországra vándorlás mellett. ${ }^{115} \mathrm{Az}$ elbeszélés egyik központi eleme az etnikai identitás, amely Erdélyben a magyar, az anyaországban pedig az erdélyi identitást jelenti. ${ }^{116}$ A másik kulcstényező a politikai hatalom, amely korlátozza, elnyomja és bizonyos választásokra kényszeríti. Már az elbeszélés elején, tanulmányai kapcsán megjelenik és befolyásolja az életét.

\footnotetext{
${ }^{115}$ A vándorlástörténet egyediségét, a felhozott motivációknak és döntési mechanizmusnak a többiekétől való különbözőségét az interjúalany eltérő életkorával járó tapasztalata is magyarázza, hiszen sokkal több időt töltött el a román munkaerőpiacon, mint a többi megkérdezett. A döntését meghatározó motivációk mint az egyéni és kollektív szintű etnikai diszkrimináció, szakmai kilátástalanság és az érvényesülés lehetöségének hiánya - elsősorban a rendszerváltozást megelőzően Magyarországra vándorolt erdélyi értelmiségiek indoklásában jelennek meg (Gödri 1998).

${ }^{116}$ Alátámasztja Sik megállapítását (Sik 2011c).
} 
„Azután 1992-ben kerültem be az orvosi egyetemre. Gyakorlatilag ez volt az első év, amikor már nem müködött a numerus clausa elve, amikor már nem felülröl határozták meg az összhallgatókból a magyar hallgatóknak a számát (...) Számomra egy fontos tényezö volt még azokban az években, hogy én kötödöm az otthonomhoz, a szülöföldemhez, és akkor még olyan szlogeneket hangoztattam, hogy én leszek, aki lekapcsolja a villanyt Erdélyben utolsónak. Hát ez nem így alakult, nem így hozta az élet” Később: „Maga ez a mókuskerék, aminek a mai nap is - látjuk a médiában, hogy most is mi zajlik a MOGYE-n a tanszékek körül-, nyilván ezek a dolgok akkor is adva voltak. És hogy milyen mértékben, hogy kivülröl az mennyire volt látható, az egy lapra tartozik. Hogy én hogy éltem meg mindezt belülröl egy olyan tanszéken, amely legendás volt arról, hogy gyakorlatilag én voltam az egyetlen magyar ember azon a tanszéken. Szóval nem volt egy kellemes környezet, amikor a laborvezetö, aki végzettségben messze alattam volt, persze nem szeretem ezt kihangsúlyozni, de rámszólt, hogy ebben a laborban csak román nyelven lehet beszélni, amikor egy diákhoz magyarul fordultam, az ö anyanyelvén, természetesen." (GL, nő, szakorvos)

Elbeszélésmódjában többnyire tárgyilagos és szenvtelen, az érzelmeit igyekszik kordában tartani.

„Még egyszer: nem gondolom, hogy nekem itt most a sérelmeket kellene sorolni és számolgatni, mert ennyi év távlatából valóban nem ez az elsödleges, és az ember szeret a szép- legalábbis az a fajta személy vagyok, aki szeret a szép dolgokra emlékezni. Jobbára ha felidézek valamit azokból az időkböl, akkor szeretem a jó dolgokat, de tudom, hogy a te témád arról szól, hogy miért is jönnek el onnan az emberek.” (GL)

Történetében az identitás szerepe nem csak a migrációt megelőző időszakban fontos, hanem a megérkezés után is. Nagy hangsúlyt fektet az integrációra, kiemelve a befogadó társadalomban felépített kollegiális kapcsolatait, amelyek mintegy ellensúlyozzák a szülőföldjén tapasztalt hátrányos megkülönböztetést.

„Én nem éreztem úgy az elmúlt évek alatt, hogy én itt jövevény lennék vagy hogy furán néznének rám (...) És gyakorlatilag ezt mondhatom, hogy mindenhol erröl szóltak az évek, mintha midenhol valahogyan láthatatlan antennákkal sikerült azokat az embereket megtalálnom, akik vagy a szimpátia miatt, valamiért érzékenyek az erdélyi sorsra, és az, hogy honnan vagyok sosem jelentett gondot." (GL) 
Az integráció alapja a közös kultúra, amely nagy szerepet játszik terveiben, és a továbbvándorlás ellen hat.

„,[T]ényleg vannak olyan emberek Magyarországon, akik érzékenyek arra, hogy mi történik velünk, hogy miért vagyunk itt, hogy mi gyakorlatilag egy nemzet vagyunk, hogy mi ugyanazon a kultúrán nöttünk föl, ugyanúgy Benedek Elek meséin nöttem föl, mint az itteni gyerekek” Később: „De a lényeg az, hogy mindig, amikor erröl [továbbvándorlásról] beszélgettünk, az a végkövetkeztetés, hogy nekünk az nagyon fontos, hogy a gyerekünk egy magyar kultúrán szocializálódjon, hogy ö magyar színházba járjon, hogy magyar népmesét olvassunk”. (GL)

Az ugyanazon nemzethez és nyelvi közösséggel való azonosuláson túl itt is megmarad a másság tudata, az erdélyi identitáshoz való ragaszkodás (Kovács \& Melegh 2001).

„, [N]ekünk a szükebb-tágabb környezetünk is erdélyi emberekböl tevödik össze, akik azért onnan származtak el, és tudat alatt vagy öntudatlanul, vagy nem tudom, hogyan nevezzem, mégis az otthoniak társaságát keressük, amikor a nagyon szük körröl van szó. Mert nyilván, hogy munkahelyi kapcsolatok, a szakma által meghatározott kapcsolatok, az más történet. De amikor a saját magánéleted, az abszolút személyes köröd, az nagyjából az otthoniakból tevődik össze.” (GL)

\section{4. Összegzés}

Összefoglalásként elmondható, hogy a megkeresett, Erdélyből bevándorolt egészségügyi dolgozók migrációs történetüket két nagy tematikus mezőben mesélik el. Az egyik az emberi viszonyrendszerek (családi kapcsolatok, baráti és rokoni migráns hálózatok, etnicitás), a másik a szakmai pálya és a hozzá kötődő témakörök.

Az átvándoroltak migrációs motivációi között leggyakrabban családi vagy párkapcsolatuk szerepel, amely egy korábban intézményesült kulturális és társadalmi minta. Ez rávilágít arra a szemléletmódjukra, hogy ők elsősorban egy családi egység tagjai vagy valakitől függnek (Melegh et al. 2010). Az interjúk második felében adott válaszok, további események megemlítése vagy aprólékosabb leírások segítenek nem csak egy árnyaltabb képet kapni a kezdő történetről, hanem rávilágítanak a döntéshozatal bonyolult mechanizmusára, a befolyásoló tényezők összetett és egymásra kölcsönösen ható valóságára. Éppen ezért csak több szinten képesek elmesélni, és a 
későbbi magyarázatok és válaszok gyakran meg is kérdőjelezik, akár megcáfolják a korábban bemutatott képet. A passzív szerep, amely többnyire más szereplőkre vagy a külső körülményekre hárítja a felelősséget, arra utal, hogy a migránsok sem értenek teljesen egyet tettükkel - szülöföldjük elhagyásával -, és ezért folyamodnak a családi kapcsolatokhoz vagy etnikumhoz (kisebbségi léthelyzet, etnikai diszkrimináció, problémák a román nyelv használatával) mint legitimizációs tényezőkhöz. Aktív szerepben is megjelennek mint önmegvalósításra törekvő vagy saját egészségügyi problémáját kezeltetni kívánó egyén.

Az aktív-passzív elbeszélésmód közötti váltogatás a magukkal hozott kettős kultúrára utal: egyfelől az erdélyi magyarság nagyon nehezen engedi el tagjait, elítéli a kivándorlást, hiszen a közösség stabilitása és léte ellenében hathat (Melegh et al. 2010; Gödri 1998; Biró 1996). Másfelől mégis nagyon elterjedt a migráció, egy migrációs kultúra alakult ki, amelyben normatívvá, elfogadott életstratégiává válik a külföldi munkavállalás (Kandel \& Massey 2002; Bodó 2008), amint arra az interjúalanyok utalnak is a vándorlás tömeges jelenségként való bemutatásával (csoportos migráció), saját korábbi migrációs tapasztalataik említésével, és a migráns hálózatokra építő, a „kitaposott utat” követő vándorlástörténeteikkel. A kettő együttes müködésének ambivalenciája feszültséget generál a narratívákban: némelyikből teljesen hiányzik a döntéstörténet. A migráns hálózatok megerősödésével és önállósulásával a vándorlási folyamat megállíthatatlanná válik: újabb és újabb tagokat toboroznak (Massey et al. 1993).

A másik fö tematikus mező, amelyben a migrációhoz vezető döntés mechanizmusát leírják, az a szakmai pályafutás, a karrier, ${ }^{117}$ amely az esetek többségében otthon el sem kezdődött, ${ }^{118}$ máskor meg rövid időn belül akadályokba ütközött, kudarcba fulladt. A külföldi karrier választása mögött a globális hierarchiák (Melegh 2012), a kibocsátó és befogadó ország egészségügyi képzési rendszere közötti különbségek, a hazai szakmai lehetőségek korlátozottsága, a korábbi tanulmányi/szakmai migrációs tapasztalat és ezzel együtt megváltozott referenciatér (de Haas 2011), a kollégák - és közvetve intézmények - toborzásos tevékenysége, a Nyugat és Kelet közötti bérkülönbségek, valamit a hazai kezdő fizetések elégtelenségétől ${ }^{119}$ és

\footnotetext{
${ }^{117}$ Toro-Morn eltérő osztályhoz tartozó bevándorló nőket kutatva tapasztalta, hogy a magasan képzett nők számára a szakmai pályán tett célkitüzéseik ugyanolyan fontosak voltak, mint családi kötelezettségeik; szemben a munkásosztálybeli nőkkel, akiknél ez utóbbi játszott elsődleges szerepet (Toro-Morn 1995).

${ }^{118}$ Ezt a jelenséget, mármint a román munkaerőpiacra való belépés elkerülése miatti migrációt, nevezik státusszorongásnak (Kiss \& Csata 2004).

${ }^{119}$ Ez a kárpátaljai frissen végzett magyar orvosok számára is problémát jelent (Orosz \& Molnár 2008).
} 
az ezzel járó lecsúszástól való félelem (státusvesztés) tényezői állnak. ${ }^{120} \mathrm{~A}$ friss diplomával átvándorolt egészségügyi dolgozók integrációja a magyar társadalomba - a nyelvi és kulturális hasonlóság ellenére - gyakran csak felszínesen, a munkahelyi környezetre korlátozódva ment végbe. ${ }^{121}$ Erre részben magyarázatul szolgál az erdélyi magyar identitáshoz való ragaszkodás, annak megőrzése; és egyben igazolja a korábbi megállapítást, hogy a szülőföld nem - és esetenként maguk a szülők sem - egykönnyen engedi el őket. Másfelől egy lebegő, sodródó állapot/létérzés kialakulásához vezet, amelyben a Nyugat-Kelet között fennálló bérkülönbségek a továbbvándorlás felé sodorhatják őket. A szoros kötődést a kibocsátó közösséggel a viszonylag kis földrajzi távolságnak köszönhető gyakori személyes kapcsolattartás tartja fenn; míg a sodródó állapot részben a migráns léttel, de inkább - Románia EU-s csatlakozását követően a határok elmosódásával és a referenciatér kitágulásával járó - egyfajta transznacionális szemléletmód és hálózatok kialakulásával magyarázható. Mindezekből kifolyólag jelenlegi (földrajzi) helyzetüket némelyek csak átmenetinek vélik, és a tovább-, illetve visszavándorlás gondolata foglalkoztatja őket, attól függően, hogy anyagi vagy érzelmi (család, szülöföld) motivációk vezérlik. A sodródás, az átmenetiség érzése és az időben elhúzódó, hosszú távú következményekkel bíró döntések lezáratlansága arra utalnak, hogy a vándorlás nem egy egyszeri, hanem apró, rövid távú, kisebb horderejü döntések sorozata. Ezért jelent kihívást a migrációs potenciál vizsgálata, mivel mérése elsősorban azon a feltételezésen alapszik, hogy a vándorlás egyetlen nagy döntés eredménye.

Helyben tartó tényezők a visszavándorlással szemben a szakmai fölény (knowhow) és a két ország egészségügyi rendszerének felszereltsége, eszközparkja közötti különbség, illetve általános jóléti és társadalmi attitüdök eltérései (pl. korrupció); a továbbvándorlással szemben pedig a magyar nyelvhez és kultúrához való ragaszkodás.

A különböző tematikus mezők nem egymástól elkülönülten, hanem egymásba fonódva, különbözőképpen összekapcsolódva jelennek meg a migrációs történetekben, ami utal a kumulált okságra (Massey 1999) és összetett mechanizmusok működésére, amelyek a vándorlók migrációs döntéseiben szerepet játszanak.

A származás szerepe, a társadalmi státus - érdekes módon - nem tematizálódik ezekben a migráns történetekben. Erre részben magyarázatként szolgálhat az, hogy a vándorlás a családi/párkapcsolati és baráti (kollegiális) migráns hálózatok révén - amelyek hozzájuk

\footnotetext{
120 A román orvosok körében is hasonló okok vezetnek a kivándorláshoz. Ök megemlítik még az egészségügyi politikák hiányosságait (befejezetlen egészségügyi reformok), a kapcsolatok szükségességét a szakmai pályán való előlépéshez, a megbecsültség hiányát és a meghirdetett rezidensi helyek elégtelenségét. Ez utóbbi keretszámait az Egészségügyi Minisztérium határozza meg a képzési központok befogadó képességéhez mérten, ami messze alatta maradhat a képzési rendszerbe belépni kívánó hallgatók számától. (Évente átlagosan 3700 hallgató diplomázott a 2000-es évek első évtizedében, míg a meghirdetett rezidensi helyek száma 1400 körüli volt) (Rohova 2011; Glinos et al. 2011).

${ }^{121}$ Ehhez nagymértékben hozzájárulhat az, hogy többségüknek a házastársa is erdélyi.
} 
hasonló társadalmi státusú csoporttagokat foglalnak magukba - vagy toborzás formájában valósult meg. 


\section{AZ ERDÉLYI, MAGYAR NYELVEN TANULÓ VÉGZŐS ORVOS-, GYÓGYSZERÉSZ ÉS NŐVÉR HALLGATÓK MIGRÁCIÓS POTENCIÁLJA. A KÉRDŐÍVES KUTATÁS EREDMÉNYEI A VIZSGÁLATI CSOPORTBAN}

„Nálunk a tendencia az, ahogy egy felmérés is kimutatta, hogy minden ötödik órában elhagyja az országot egy orvos, és az egyetemisták több mint 70 százaléka akar külföldre menni, mert a fizetések nagyon alacsonyak. Bármilyen EU-s országhoz hasonlitva, azt hiszem, itt a legalacsonyabb",122

A kutatás alapkérdése - amint a Bevezető rész utalt rá - az volt, hogy mekkora a migrációs potenciál a magyar tannyelvü végzős orvostan-, fogorvos-, gyógyszerész- és nővérképző hallgatók körében.

Ebben a fejezetben sorra megvizsgálom kereszttáblák segítségével azokat a tényezőket, amelyek a migráció tervezéséhez vezethetnek, majd modellezni próbálom ezeket. Utána a helyben tartó, illetve a maradás feltételeiként megnevezett tényezőket elemzem.

\subsection{Nyers migrációs potenciál}

A nyers migrációs potenciált a „Tervezed-e, hogy külföldön dolgozol?” kérdésre adott válaszok mérik. $^{123}$

3. táblázat: Külföldi munkavállalás tervezése

\begin{tabular}{lc} 
Tervezi, hogy külföldön dolgozzon & $\%$ \\
\hline Biztosan nem & 7 \\
Kevéssé valószínü & 18 \\
Igen, de előbb otthon próbálkozik & 27 \\
Nagyon valószínủ & 16 \\
Biztosan igen & 17 \\
Még nem döntött & 15 \\
\hline$N$ & 248
\end{tabular}

\footnotetext{
${ }^{122}$ Idézet az egyik hallgatóval készült interjúból.

123 Ezt megelőzte egy másik kérdés: „Gondoltál-e már arra, hogy külföldön vállalj munkát?”. Értelemszerüen szorosan összefügg a kettő, viszont érdekelt, hogy vannak-e olyanok, akikben például többször is felmerült a külföldi munka gondolata, de tervek szintjén nem jön elö. Ez a fajta magatartás kevéssé jellemző: mindössze 8 hallgató van, aki többször is gondolt a külföldi munkára, illetve komolyan fontolgatja, de el is veti a migráció tervét vagy kevéssé tartja valószínűnek. Érdekes módon inkább a feltételezett mechanizmus fordított működése figyelhető meg: a migrációra néha gondolók (99 fö) egyharmada „otthoni próbálkozást” követően tervez elmenni, ötöde még határozatlan és hárman nagyon valószínűnek vagy biztosnak tartják, hogy külföldön vállalnak munkát.
} 
Megállapítható, hogy a hallgatók többségének tervében szerepel a külföldi munkavállalás, mindössze 7 százaléka zárja azt ki teljesen, illetve összesen egynegyede nem tervezi. ${ }^{124}$ A külföldön munkát vállalni szándékozók aránya jóval magasabb, mint amekkora általában az erdélyi magyar felnőtt népességre jellemző; ${ }^{125}$ ami nem meglepő, hiszen fiatalabb korosztályról lévén szó, ezt eleve feltételeztem. A csak - erdélyi magyar - fiatalok (17-30 évesek) külföldi munkavállalási szándékával való összehasonlításkor ${ }^{126}$ a különbség jóformán eltűnik: a fiataloknak közel háromötöde (58\%) tervez külföldi munkavállalást, további egyötöd-egyötöde pedig kitelepedést és/vagy tanulást. ${ }^{127} \mathrm{Ez}$ alapján a kor hatása - miszerint a fiatalabb életkor serkenti a migrációs hajlandóságot - a vándorlási tervekre visszaigazolást nyert. A már felsőfokú végzettséggel rendelkező erdélyi fiatalok külföldi munkavállalási hajlandósága viszont kissé elmarad az átlagtól: fele nem tervez külföldön munkát vállalni. ${ }^{128}$

A magyarországi adatok tükrében kissé magasnak mondható a vizsgált népesség migrációs potenciál arányszáma: a SOTE hallgatóknak ugyancsak egynegyede nem tervez külföldi munkavállalást diplomája megszerzése után, kétötöde viszont igen és 36 százaléka még bizonytalan terveiben. ${ }^{129}$ Ennél kissé magasabb a magyarországi rezidens orvosok külföldi munkavállalási hajlandósága, mintegy fele jelezte ezirányú szándékát; ${ }^{130}$ viszont, mint korábban erre utalás történt, ${ }^{131}$ ez utóbbi csoport már túljutott egy migrációs szelekciós mechanizmuson.

A két hallgatói csoport (erdélyi és magyarországi) adatainak összehasonlításából az a következtetés vonható le - a narratív interjúk eredményei alapján -, hogy az erdélyi magasabb migrációs potenciál kialakulásában a szakmai okok és a globális hierarchiában elfoglalt relatív pozíció (Románia kedvezőtlenebb helyzete

\footnotetext{
124 A továbbiakban a biztos nem és nem valószínű válaszlehetőségek, illetve a nagyon valószínü és biztosan igen kategóriák összevontan szerepelnek.

${ }^{125}$ A kolozsvári Nemzeti Kisebbségkutató Intézet 2013. nyarán végzett reprezentatív kutatása szerint az erdélyi magyar felnőtt lakosság körében a külföldi munkavállalási potenciál 26 százalékos, míg az elvándorlásé 10 százalék (NKI 2013).

126 Köszönet a kutatás vezetőinek, hogy rendelkezésemre bocsátották az adatbázist az elemzések elvégzésére.

127 A kategóriák között nagy az átfedés: több mint egynegyede kettő vagy három migrációs formát is megjelölt, és 39 százaléka csak egyet.

128 A vizsgált népesség viszont még nem tartozik ebbe a kategóriába, hiszen még diplomázás előtt vannak; még nem léptek ki a munkaerőpiacra.

${ }^{129}$ A kutatás a Diplomás Pályakövetési Rendszer keretében valósult meg 2012-ben. Köszönet az Educatio Társadalmi Szolgáltató Nonprofit Kft.-nek, hogy rendelkezésemre bocsátotta az adatbázist. Az összehasonlításhoz a SOTE általános orvostudományi, egészségtudományi, fogorvos-tudományi és gyógyszerésztudományi karai hallgatóinak adatait használtam. A kutatás eredményeiről bővebben lásd: (DPR 2013).

${ }^{130}$ A gyorsjelentés felhívja a figyelmet, hogy ez az arányszám alacsonyabb, mint a korábbi években tapasztaltak (EMK 2012). A román egészségügyi dolgozóknak ugyancsak fele szándékozott munkát vállalni külföldön az EU-s csatlakozás évében (Rohova 2011).

${ }^{131}$ Lásd a 68. lábjegyzetet.
} 
Magyarországhoz képest) tényezőin kívül (Melegh 2012) a kisebbségi léthelyzet is szerepet játszhat.

8.1.1. A migrációs potenciált általában befolyásoló szociodemográfiai tényezők és azok hatásai

4. táblázat. A szociodemográfiai tényezök hatása a migrációs tervekre

Elöbb

otthon

Tervez külföldi munkavállalást (\%) Nem Igen próbálkozik Határozatlan $\quad N$

Nem

Férfi

$30 \quad 30$

27

13

56

Nő

$23 \quad 33$

26

18

193

Életkor

24 éves vagy fiatalabb

$23 \quad 31$

29

17

205

25 éves vagy idősebb

$37 \quad 37$

17

9

41

Családi állapot *

Nőtlen/hajadon

$20 \quad 32$

25

22

100

Párkapcsolata van

$21 \quad 34$

34

Házas

$44 \quad 32$

24

Együtt él nem házasságban

37

28

16

11

88

Hallgatott szak *

Orvos

Fogorvos

Gyógyszerész

$25 \quad 17$

25

19

44

28

\section{4}

Nővér

20

40

24

33

27

29 posztgraduális)

(technikum-

Anya iskolai végzettsége

Alapfokú (szakiskola v. kevesebb)

(technikum-

Felsőfokú

$25 \quad 31$

28

16

105

Apa foglalkozása

Szellemi/vállalkozó/önálló

$\begin{array}{ll}16 & 49\end{array}$

$26 \quad 27$

Szellemi/vállalkozó/önálló

Vezetői/diplomás alkalmazott

Munkás/gazdálkodó

$28 \quad 26$

$14 \quad 43$


Társadalmi státus*

\begin{tabular}{lccccc} 
Alacsony & 22 & 33 & 30 & 15 & 79 \\
Vegyes & 33 & 36 & 13 & 18 & 72 \\
Magas & 21 & 28 & 37 & 14 & 92 \\
$\begin{array}{l}\text { zubjektív anyagi helyzet } \\
\text { Szegény }\end{array}$ & 32 & 32 & 18 & 18 & 60 \\
Közepes anyagi helyzet & 18 & 32 & 30 & 20 & 103 \\
Gazdag & 29 & 31 & 33 & 7 & 75 \\
\hline Sszesen & & &
\end{tabular}

A nemek között nincs jelentős eltérés: bár a férfiak nagyobb arányban vetik el a külföldi munka gondolatát, a nőkre a határozatlanság is sokkal inkább jellemző, így az összefüggés nem szignifikáns. A nemek szerinti kiegyenlítettség alátámasztja a korábbi megfigyeléseket ${ }^{132}$ (Örkény 2003; Tóth 2004), illetve várakozásomat erre vonatkozóan. Életkor tekintetében a 25 évesek és idősebbek határozottabbak mind külföldi munkavállalási, mind pedig maradási szándékaikban, míg fiatalabb csoporttársaik inkább határozatlanok és ,„próbálkoznának előbb otthon”. ${ }^{133},{ }^{134}$

Szignifikánsan különbség tapasztalható a családi állapot tekintetében. A nem együttélő párkapcsolattal rendelkezőkre jellemző leginkább a külföldi munkavállalás tervezése, legkevésbé pedig az együtt élőkre. A házasoknak - a hajadonokhoz/nőtlenekhez hasonlóan - több mint fele szándékszik külföldre menni; jóllehet az otthon maradás mellett is leginkább ők döntenek. A határozatlanság leginkább a hajadon/nőtlenek csoportjára és az együtt élőkre jellemző ( $\chi^{2}=17,368$; szig.:0,043). ${ }^{135}$

Hallgatott szak szerint külföldi munkavállalást legnagyobb mértékben a nővérek majdnem háromnegyede - terveznek és legkevésbé a gyógyszerészek. Az orvos és fogorvos hallgatóknak mintegy fele szándékszik külföldre menni, viszont a fogorvosok inkább „előbb otthon próbálkoznának”. A gyógyszerészek egyharmada még bizonytalan terveiben és egynegyede nem tervez migrációt $\left(\chi^{2}=20,971\right.$, szig. $\left.=0,013\right) .{ }^{136}$

\footnotetext{
132 Sőt, fokozatosan a nők felülreprezentáltsága figyelhető meg az erdélyi bevándorlók között (Gödri \& Tóth 2005; Hárs 2010).

${ }^{133}$ Három korcsoportra bontásban viszont - és a kormegoszlás alapján ez indokoltnak tünhet -, illetve a határozatlanok kihagyásával már kiélesednek a különbségek: a 23 éves és fiatalabb korcsoport háromnegyede (78\%) tervez előbb-utóbb külföldi munkavállalást, a 24 évesek 64 százaléka és a 25 éves meg idősebb korcsoport háromötöde (szig.: 0,060).

${ }^{134}$ Az erdélyi magyar fiatalok körében föként a 24-30 éves korosztály tagjai szeretnének nagyobb arányban otthon munkát vállalni (kevesebb, mint fele tervezi a migrációt), míg a nagyon fiatalok esetében a migrációs potenciál hasonló a hallgatók ugyanazon korosztályba tartozó tagjaiéhoz.

135 Egy korábbi kutatás eredményei alapján a családi állapot hatása csak a hosszú távú külföldi munkavállalási szándék esetében volt szignifikáns: a nőtlenek/ hajadonok, illetve az élettárssal élők a családosoknál nagyobb arányban tervezték ezt a típusú migrációt (Gödri \& Kiss 2009).

${ }^{136}$ A magyarországi hallgatók esetében egy fordított sorrend tapasztalható. Miközben közel egyharmaduk bizonytalan terveit illetően - minden kar esetében -, legkevésbé az egészségtudományi kar hallgatói
} 
A szülők iskolai végzettsége a korábbi tapasztalatokhoz híven - amelyek ugyan a válaszadó iskolai végzettségével dolgoztak (Kiss \& Csata 2004) - nem befolyásolja a külföldi munkavállalást tervezők arányát $\left(57-65 \%\right.$ közötti), ${ }^{137}$ viszont eltérő stratégiákhoz vezet. Az alacsonyabb szülői kulturális tőkével rendelkezők átlagon felül szándékoznak külföldön vállalni munkát, a közepes (érettségi) iskolai végzettségü szülők gyerekei „előbb otthon próbálkoznának”, és a legmagasabban iskolázottak gyerekei kissé nagyobb arányban tervezik a helyben maradást. Ez összefügg az előző pont megállapításával, mert a hallgatott szak és a szülők iskolai végzettsége nagyon szorosan összefügg. Mivel a nővérek származnak leginkább kulturális tőke-szegényebb családokból és a fogorvosok a legkevésbé, így hasonló összefüggés mutatkozik akár a szak, akár a szülők végzettségének a külföldi munkavállalási szándékra gyakorolt hatásának vizsgálatakor. Ez arra utal, hogy a felfelé mobilak inkább tervezik a külföldi munkavállalást ${ }^{138}$.

A szülők foglalkozásának nincs szignifikáns hatása, bár kisebb eltérések megfigyelhetők. A gazdaságilag inaktív, munkanélküli és elhunyt szülők gyermekei a legkevésbé, a vállalkozó, önálló és szabad szellemi foglalkozású apáké és a kékgalléros anyáké pedig leginkább szándékoznak munkát vállalni külföldön. Feltételezhezően egyfelől szakmai/presztízs okok játszanak szerepet, vagyis a migráció a státusmegőrzést is szolgálhatja, míg másfelől a kétféle mobilitás - társadalmi és földrajzi összekapcsolódása ${ }^{139}$ is megfigyelhető. ${ }^{140}$

A családi társadalmi státust vizsgálva megállapítható, hogy a vegyes státusúak kisebb arányban terveznek külföldön munkát vállalni. Valószínüleg a szülők iskolai végzettsége és foglalkozása, vagy még inkább az apa és anya foglalkozása közötti

(32\%), leginkább pedig a fogorvos-tudományi kar hallgatói (59\%) szándékoznak külföldön munkát vállalni; a gyógyszerész hallgatók pedig az általános orvostan-hallgatóknál kissé magasabb arányban.

137 A magyarországi kutatás eltérő eredményt hoz: a szülők iskolázottsági szintjének emelkedésével párhuzamosan a hallgatók külföldi munkavállalási hajlandósága is növekszik.

${ }_{138}$ A földrajzi és társadalmi mobilitás összekapcsolódása volt jellemző az Erdélyből érkezett bevándorlókra is (Gödri 2010). Ám jelen esetben összevont kategóriák alkalmazásával - a határozatlanok kihagyásával - az alacsony és magas státusú családból jövők egyenlő mértékben tervezik a migrációt; a vegyes státusúak kisebb arányban. Ez utóbbi összefüggést megerősítik a későbbi interjúk is. A tisztított migrációs potenciál pedig nagyon hasonló mindhárom csoportban (49-54\%).

${ }^{139}$ Lásd elöző bekezdéseben a szülők végzettsége kapcsán leírtakat. Hasonló mechanizmus müködését figyelték meg más kutatók is: az osztályhelyzetük megőrzéséért vagy osztálymobilitásuk biztosításáért küzdő családok a Dominikai Köztársaságból az USA-ba küldik némely tagjukat. A tanulmány megállapítása szerint a migráció és az általa létrehozott transznacionális hálózatok olyan stratégiák, melyek révén a háztartás képes megőrizni azt, amit birtokol, legyen az erőforrás vagy társadalmi helyzet (Glick Schiller et al. 1995).

${ }^{140} \mathrm{Az}$ erdélyi magyar fiatalok között leginkább a diákok (68\%) és a kékgallérosok (szak-, betanított- és segédmunkások: $62 \%$ ) tervezik a külföldi munkavállalást; legkevésbé a vállalkozói/ vezetői beosztással rendelkezö/ szellemi alkalmazotti réteg $(47 \%)$. 
diszkrepancia hatása húzódik meg a háttérben, amelyek akár egymás ellenében hathatnak a vegyes státus esetében, mintegy semlegesítve az egymást. ${ }^{141}$

A szubjektív anyagi helyzet lényeges eleme a migrációs terveknek. Az, hogy az egyén milyennek ítéli meg anyagi állapotát, inkább meghatározó szándékai befolyásolásában, mint maga az objektív anyagi helyzet (Demuth 2000). A szülők szubjektív anyagi helyzetét 2 skála mérte: az egyik a nagyon szegénytől a nagyon gazdagig terjedő 11 fokú skála, míg a másik a „nélkülözések között élnek” és a „gondok nélkül élnek” közötti 5 fokú skála volt. Legkedvezőbb anyagi háttérrel a fogorvos hallgatók rendelkeznek: közel háromnegyede jól vagy anyagi gondok nélkül él, illetve anyagi gondokkal leginkább a nővéri pályát választók szülei küzdenek (45\%). Hasonló mintázat látható a gazdagsági szint értékelésében, bár itt csak a fogorvos hallgatók rendelkeznek kiugró értékkel, akiknek majdnem fele (46\%) szüleit gazdagnak véli (skála 7-10 terjedő értékei) és csak nyolcada „szegény” (skála 4-es vagy kisebb értékei); a másik három szakon a hallgatók több mint negyede (26-30\%) rosszabb jövedelmi helyzettel bíró szülők gyermeke. ${ }^{142} \mathrm{Az}$ anyagi nehézségek megléte illetve hiánya csak gyengén hat a kedvezőtlen anyagi helyzettel rendelkezők helyben maradási vagy külföldi munkavállalási hajlandóságára, de a vagyonossági skálával már pontosabb kép nyerhető. A fejlődési elmélet megállapításához hủen ${ }^{143}$ (de Haas 2011) a magukat közepes és a nagyon jó anyagi helyzettel rendelkezőknek tartók tervezik leginkább a külföldi munkát, bár a magukat gazdagnak vélők majdnem a rosszabb anyagi helyzettel rendelkezőkhöz (,szegények”) hasonló arányban vetik el a migráció tervét ( $\chi^{2}=12,720$, szig.:0,048). ${ }^{144}$ A két alsó kategóriába tartozókra sokkal inkább jellemző a határozatlanság. ${ }^{145}$

\footnotetext{
141 A foglalkozási csoportokat más módon való összevonásakor a szülői státus hatása teljesen eltünt. Viszont a későbbi interjúk megerősítik, hogy a helyben maradás mellett leginkább a vegyes státusú családokból jövők döntenek.

${ }^{142}$ A kétféle skála eredményei nemcsak egymással függnek össze szignifikánsan $\left(\chi^{2}=53,335\right.$; szig.:0,000), hanem a családi státussal is. Viszont a vegyes státusú családból származók anyagi helyzetüknek értékelésében nem egy „,középutat” követnek, hanem az alacsony státusúakéhoz hasonló értékelést.

${ }^{143}$ A fejlődés kezdeti szakaszában nem csökken a migránsok száma, hanem még tovább növekszik, mivel ekkor már rendelkezésre állnak a vándorlás megvalósításához szükséges eszközök (de Haas 2011).

${ }^{144}$ A magyarországi hallgatók körében is az átlagosnál jobb anyagi helyzetben élők tervezik leginkább a munkavállalást, viszont sorrendben az átlagosnál rosszabb anyagi körülmények között élök követik őket.

${ }^{145}$ A határozatlanok kizárásával, illetve a 'tervezi-nem tervezi' dummy változó megalkotásával egymásnak ellentmondó eredményt hoz a két féle szubjektív anyagi helyzet; jóllehet nem szignifikánsak az összefüggések. Az anyagi nehézségekkel küzdő családokban élők kissé nagyobb arányban tervezik a migrációt, mint az anyagi gondok nélkül élök (72 százalék a 67 százalékkal szemben). Ez az összefüggés a szülök iskolai végzettsége alapján tett megállapítást erősíti meg. Viszont a másik változó alapján a magukat átlagos anyagi helyzettel rendelkezőknek és vagyonosak ítélők inkább szándékoznak külföldre menni, mint a „szegények”. Jóllehet más migrációs potenciál kutatás is megerősítette, hogy a vagyontalanság, szubjektív szegénység csökkenti a külföldi munkavállalás esélyét, viszont a megélhetési gondok is ugyanilyen hatást fejtettek ki (Koltai \& Sik 2012).
} 
Az anyagi helyzet mérését még egy további változó segítette: a saját lakóingatlannal való rendelkezés. A végzősök hatodának (15\%) van saját lakóingatlana; a birtoklás nem az anyagi helyzettel, hanem a korral és családi állapottal függ össze, vagyis az idősebbek és házasok átlagon felül bírnak saját lakással/házzal. Az ingatlannal való rendelkezés némileg a helyben maradási szándékot erősíti, jóllehet az összefüggés nem szignifikáns.

\subsubsection{A tervezett időtartam}

6. ábra: A külföldi munkavállalás tervezett idötartamának relatív gyakorisága a hallgatott szak függvényében

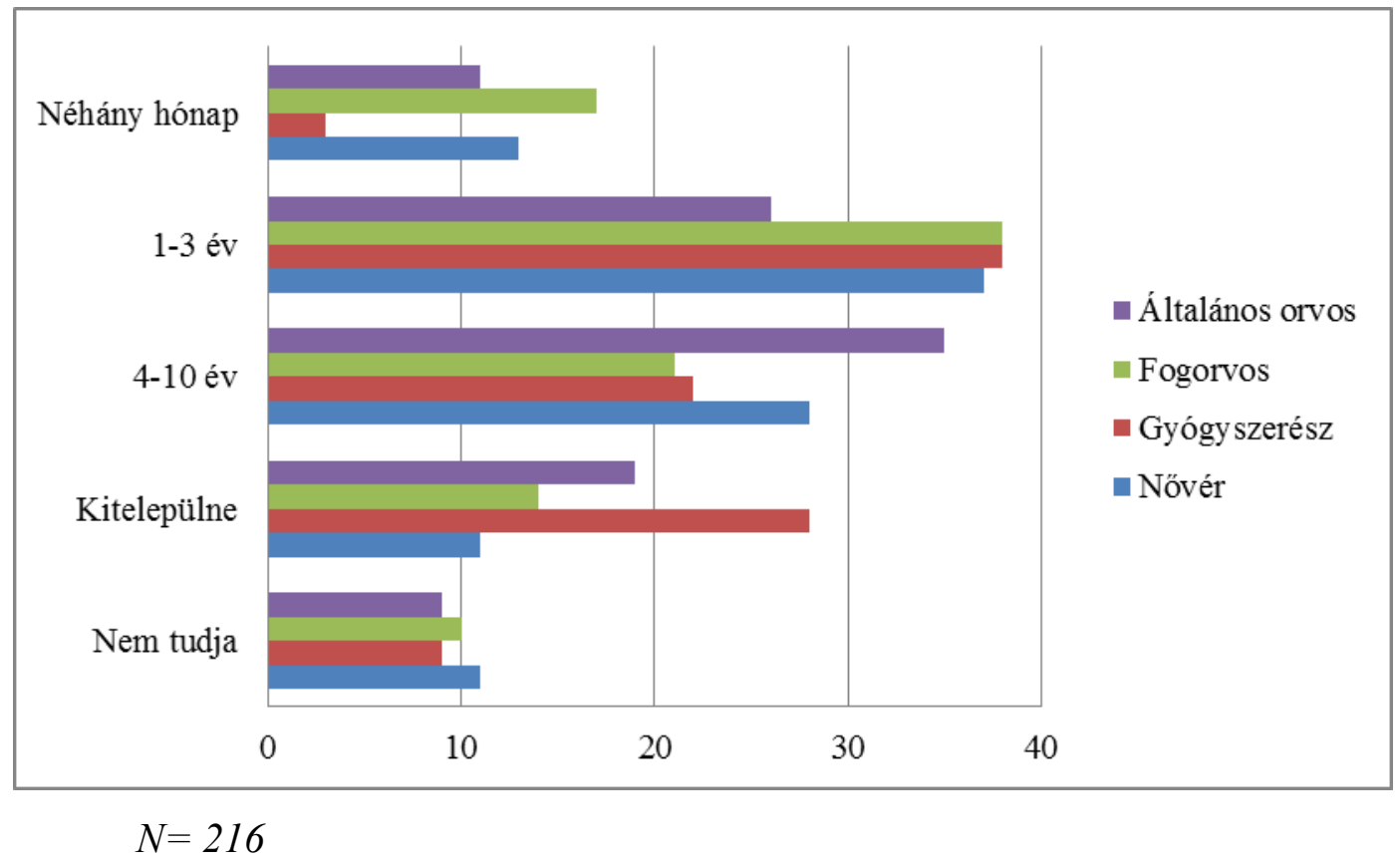

A rövidtávú, néhány hónapos külföldi munkavállalást, ami tapasztalatszerzésnek is tekinthető, átlag fölött a fogorvosok és nővérek tervezik; ${ }^{146}$ ellenben a végleges elvándorlás gondolata leginkább a gyógyszerészekre jellemző (egyharmada). A középtávú (1-3 éves) külföldi munkavállalás tervezése a leggyakoribb valamennyi csoport esetében, az orvostan-hallgatókat kivéve, akik elsősorban a hosszú távú (4-10 éves) migrációra készülnek (38\%). ${ }^{147}$

Családi állapot szerint a házasok és az együtt élők leginkább a középtávú és a végleges elvándorlást tervezik, az egyedülállók és párkapcsolattal rendelkezők pedig a hosszú és középtávú migrációt.

Szignifikáns az összefüggés a külföldi munkavállalás tervezett ideje és időtartama

\footnotetext{
${ }^{146}$ A határozatlanokat kihagyva az elemzésből.

${ }^{147}$ Ez egyfelől a migrációs motivációk, másfelől a szakterületek sajátosságainak következménye. Hiszen egy szakmai, tanulási célú vándorlás - mint pl. a rezidensi képzés elvégzése - átlagosan 5 évet vesz igénybe egy külföldi szakvizsgát megszerezni vágyó orvos számára.
} 
között: a közvetlenül diplomázás után vándorolni szándékozók fele hosszú távú, egynegyede pedig végleges elvándorlást tervez. A néhány év múlva elindulni vágyók inkább a középtávú és hosszú távú migrációt (43\% és 32\%) tervezik.

A kapcsolati tőke megléte szintén befolyásolja - jóllehet nem szignifikáns módon - a tervezett külföldi munkavállalás időtartamát. Hasonló módon hatnak az erős és a gyenge kötések $^{148}$ ebben az esetben: a családtag/rokon vagy barát/ismerős jelenléte a célországban szinte ugyanolyan módon befolyásolják a tervezett időtartamot. Több, mint egyharmaduk a hosszú távú, egynegyedük- egynegyedük pedig a kitelepülést, illetve a középtávú migrációt tervezi. A migráns kapcsolati tőke-szegények leginkább a középtávú migrációra készülnek (45\%), illetve átlag fölött tervezik a rövidtávú munkavállalást $(13 \%) .{ }^{149} \mathrm{Az}$ alacsony társadalmi státusúak átlag fölött tervezik a középtávú vándorlást (41\%), de a hosszú távú is gyakori (36\%). A magas státusúakra is ez a két időtáv a jellemző (38\% és 34\%), de nagyobb arányban tervezik a kitelepülést (18\%). A vegyes státusú családokból jövők hasonló arányban (29-31\%) terveznek minden - a rövid távú kivételével - típusú munkavállalási formát.

7. ábra: A külföldi munkavállalás tervezett idötartama a szülök szubjektív anyagi helyzetének függvényében (relatív gyakoriság)

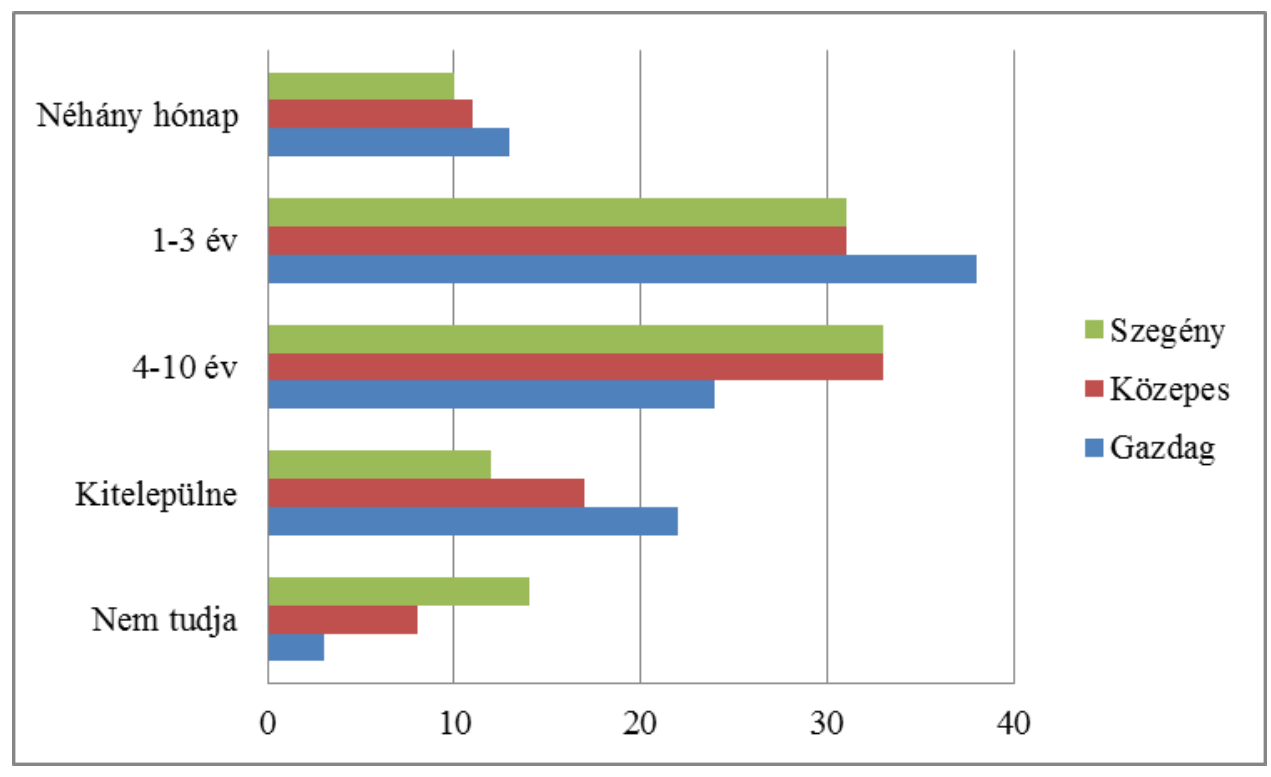

$N=198$

A szülök szubjektív anyagi helyzete oly módon hat a tervezett időtartamra, hogy a jobb jövedelmi helyzet egy kissé növeli a középtávú migráció és a kivándorlás szándékát a hosszú távú migráció rovására. A rosszabb jövedelmi helyzet pedig a bizonytalankodók

\footnotetext{
${ }^{148}$ A gyenge kötések fogalmának konceptualizálása az értekezésben eltér a Granovetter által megalkotott kifejezéstől, mivel a baráti viszonyokat is magában foglalja, függetlenül a kapcsolatok tényleges „erősségétől” (Granovetter 2010).

${ }^{149}$ Bár ez utóbbi a rokoni kapcsolatokkal rendelkezőkre is jellemző (12\%).
} 
arányát növeli.

\subsubsection{A kapcsolati tőke szerepe a külföldi munka tervezésében}

A kapcsolati tőke az egyént körülvevő személyes és tágabb körü kapcsolati hálót jelenti, amely az egyén migrációs döntését befolyásolja. Az elméleti részben leírt megállapításokat alátámasztva ${ }^{150}$ a narratív interjúk bizonyítják, hogy milyen nagyon fontos szerepet tölt be. Minél több olyan emberrel áll kapcsolatban valaki, akik külföldön dolgoztak/dolgoznak vagy élnek, annál inkább nő a valószínüsége annak, hogy ő maga is a migráció mellett dönt (Tilly 2001). Jelen kutatás a választott célországba mutató kapcsolatot, és annak a migrációs szándékokra gyakorolt hatását vizsgálta.

A külföldi munkát fontolgatók felének nincs személyes kapcsolata a célországban élö vagy tartózkódó személlyel; ők kissé nagyobb arányban vetik el a külföldi munkavállalás tervét.

5. táblázat: Kapcsolati tőke szerepe a migráció tervezésében

Tervez külföldi munkavállalást (\%)

\begin{tabular}{lccccc} 
A célországban & Nem & Igen & Elöbb otthon próbálkozik & Határozatlan & $N$ \\
\hline Nincs kapcsolata & 22 & 31 & 33 & 14 & 111 \\
Van kapcsolata & 10 & 43 & 26 & 21 & 107 \\
\hline Összesen & & & & 218
\end{tabular}

A migrációt tervező végzősök negyedének él az adott országban rokona, hatoduknak barátja, és minden kilencediknek ismeröse.

6. táblázat: A migráns kapcsolat típusa és hatása a munkavállalási tervekre

Tervez külföldi munkavállalást (\%)

\begin{tabular}{lccccc}
$\begin{array}{l}\text { A célországban } \\
\text { él... }\end{array}$ & Nem & Igen & Elöbb otthon próbálkozik & Határozatlan & $N$ \\
\hline Rokona & 13 & 43 & 25 & 19 & 47 \\
Barátja & 7 & 54 & 24 & 15 & 41 \\
Ismeröse & 5 & 26 & 32 & 37 & 19 \\
\hline Összesen & & & & 107
\end{tabular}

$\mathrm{Az}$ érintett országokban élő barátok négyötöde magyar nemzetiségü, illetve erdélyi származású, a fennmaradó 19-20 százalék viszont helybeli és nem magyar nemzetiségü. Ez utal a migráns kapcsolatok erős beágyazottságára, amelynek tagjai zömében a kibocsátó közösségből származnak, viszont a kapcsolatok kezdődő kiszélesedésére is, vagyis a kibocsátó és befogadó hálózatok összefonódására (Tilly 2001). A külföldön élő

${ }^{150}$ Lásd pl.: (Portes 1995; Massey 1999; Castles \& Miller 2009). 
emberekkel kapcsolatban állók több mint fele tapasztalt személyes toborzást (Sassen 2007) külföldi munkavállalásra a rokonai, barátai részéről, további egynegyedüket látogatóba hívták - ami szolgálhatja a „körülnézést” -, ötödüket pedig egyáltalán nem invitálták. ${ }^{151}$

Szoros, de nem szignifikáns összefüggés mutatkozik a kapcsolat típusa és a migrációs tervek között. Leginkább egy barát jelenléte az adott országban vezet a külföldi munkavállalás tervezéséhez, de a rokon jelenléte is bátorítja azt. ${ }^{152}$ Ez megerősíti azt a korábbi megállapítást, hogy a fiatalok számára fontosabb szerepet töltenek be migrációs szándékaikban a baráti, mint a rokonsági kapcsolatok (Gödri 2010; Gödri \& Kiss 2009). A kapcsolati tőke-szegények inkább döntenek a helyben maradás, illetve az „előbb otthon próbálkozás" mellett. A kívülről érkező bátorítás is növeli a migrációs hajlandóságot. Másfelől viszont a látogatóba hívott emberek kevésbé tervezik a külföldi munkavállalást, illetve nagyobb arányban határozatlanok, mint azok, akiket sem látogatás, sem pedig munkavállalás céljából nem hívogattak külföldön élő rokonaik, barátaik vagy ismerőseik. Viszont az alacsony esetszám miatt óvatosság szükséges ezen összefüggések értelmezésekor.

A kapcsolati tőke fontossága megmutatkozik nem csak a migrációs szándékra gyakorolt hatásában, hanem információforrásként is kulcsfontosságú szerepet tölt be (Portes 1998; Sassen 1995). A narratív interjúk is alátámasztják ezt az összefüggést, hiszen a feltárt típusok mindegyikében jelen van.

A külföldi munkavállalást előmozdító lépések közül első helyen áll a magyar nyelven tanulók esetében a barátoktól/ismerősöktől való személyes érdeklődés (33 százalékuk említette), megelőzve az interneten gyüjtött információk említési gyakoriságát ${ }^{153}$ (18\%).

\subsubsection{Célországok}

Arra a kérdésre, hogy melyik országban vállalna munkát, több országot is megjelöltek a válaszadók. Az erdélyi magyarság körében mindig is népszerű Németország a legkedveltebb (Sik \& Simonovits 2003). Magyarország vonzerejének hanyatlása (Gödri \& Kiss 2009) itt is tetten érhető: a harmadik helyet foglalja el, Anglia megelőzi őt. ${ }^{154}$ Ennek okai között a már korábban említett magyar egészségügy átszervezése, leépítések stb. szerepelhetnek, illetve a 2007. januárjától már a román állampolgárok részére is

\footnotetext{
151 A szakirodalom megállapítja, hogy a migráns hálózatok és azok munkahelyre toborzó hatása gender alapú: a nők inkább rokoni, míg a férfiak inkább munkahelyi kapcsolataikra támaszkodva döntenek (Sassen 1995; Bagchi 2001). Az alacsony esetszám miatt ez az összefüggés nem volt vizsgálható.

152 A barát és ismerős kategóriák összevonásakor is megmarad a gyenge kötéseknek a külföldi munkavállalási tervekre gyakorolt erősebb hatása a családi/rokoni kapcsolatokéhoz képest.

${ }^{153}$ Több válaszlehetöség megjelölésére volt lehetőség.

154 Az erdélyi magyar fiatalok által megjelölt célországok is hasonló rangsort követnek, azzal a különbséggel, hogy a Skandináv országok megelözik Magyarországot.
} 
elérhető más országok munkaerőpiacai nagyobb komparatív előnyöket kínálnak a külföldi munkát fontolgatók számára.

7. táblázat: Említett célországok gyakoriságai (\%)

\begin{tabular}{lc} 
Melyik országba menne & $\%$ \\
\hline Németország & 32 \\
Anglia & 26 \\
Magyarország & 20 \\
Skandináv országok & 9 \\
USA & 3 \\
Olaszország & 3 \\
Franciaország & 2 \\
Más EU-s ország & 3 \\
Nem EU-s országok & 3 \\
\hline \multicolumn{2}{c}{$N=232$} \\
Megj.: Több országot is meg lehetett jelölni
\end{tabular}

Németország valamennyi szak számára - a gyógyszerészek kivételével - célország (4347 százalékuk említi). Angliát a gyógyszerészhallgatók választják átlagon felül (50\%), és az orvostanhallgatók a legkevésbé (27\%). Magyarország leginkább a fogorvos szakra járók számára vonzó, 43 százalékuk jelölte meg, ami azt jelenti egyben, hogy számukra az anyaország éppúgy az első helyen áll, mint Németország. Legkevésbé a nővérek készülnek Magyarországra (20\%), mivel - amint az már a narratív interjúkból is kiderült - részükre már nem jelent előrelépést az anyaországi munkavállalás. A Skandináv országok leginkább az orvosi és fogorvosi hallgatók számára, az USA a gyógyszerész és nővér hallgatók számára célterület; Európai Unión kívüli országokat többnyire fogorvosok (13\%) és orvosok (7\%) jelöltek meg. Az említett, más EU-s és nem EU-s országok között szerepel (az említések gyakorisága szerinti sorrendben): Svájc, Írország, Új-Zéland, Ausztrália, arab országok, Ausztria, Hollandia, Kanada.

Nincs összefüggés a társadalmi státus és a célország megválasztása között, tehát a korábbi kutatások eredményeire (Kiss 2012) alapozott feltételezésem, miszerint Magyarországot inkább az alacsony (24\%) és vegyes státusúak (34\%) választják, nem igazolódott be (a magas státusúak: 27\%). A későbbiekben készített interjúk is megerősítik, hogy inkább a magas státussal rendelkezők - avagy státusmegőrzők említették Magyarországot. Ennek egyik alapvető oka a korábbi, tanulmányi célú migrációs tapasztalat, amely kiszélesítette a potenciális migráns referenciaterét és bővítette társadalmi tőkéjét; a másik fő ok meg a migráció motivációjában található: a szakmai továbbképzés vagy tapasztalatszerzés vezérli inkább, mintsem a két ország közötti bérkülöbségek. Ezen felül szerepet játszanak még a migráns hálózatok, a nyelvi azonosság (egy idegen szaknyelv ismeretének hiánya), párkapcsolat. 


\subsubsection{A külföldi munkavállalás időzítése}

A migráció időzítése eltér a különböző országok esetében, amely összefüggésbe hozható az adott országnak a különböző szakos hallgatók körében tapasztalt népszerüségével.

8. ábra: A leggyakrabban megjelölt célországok a migráció tervezett ideje függvényében

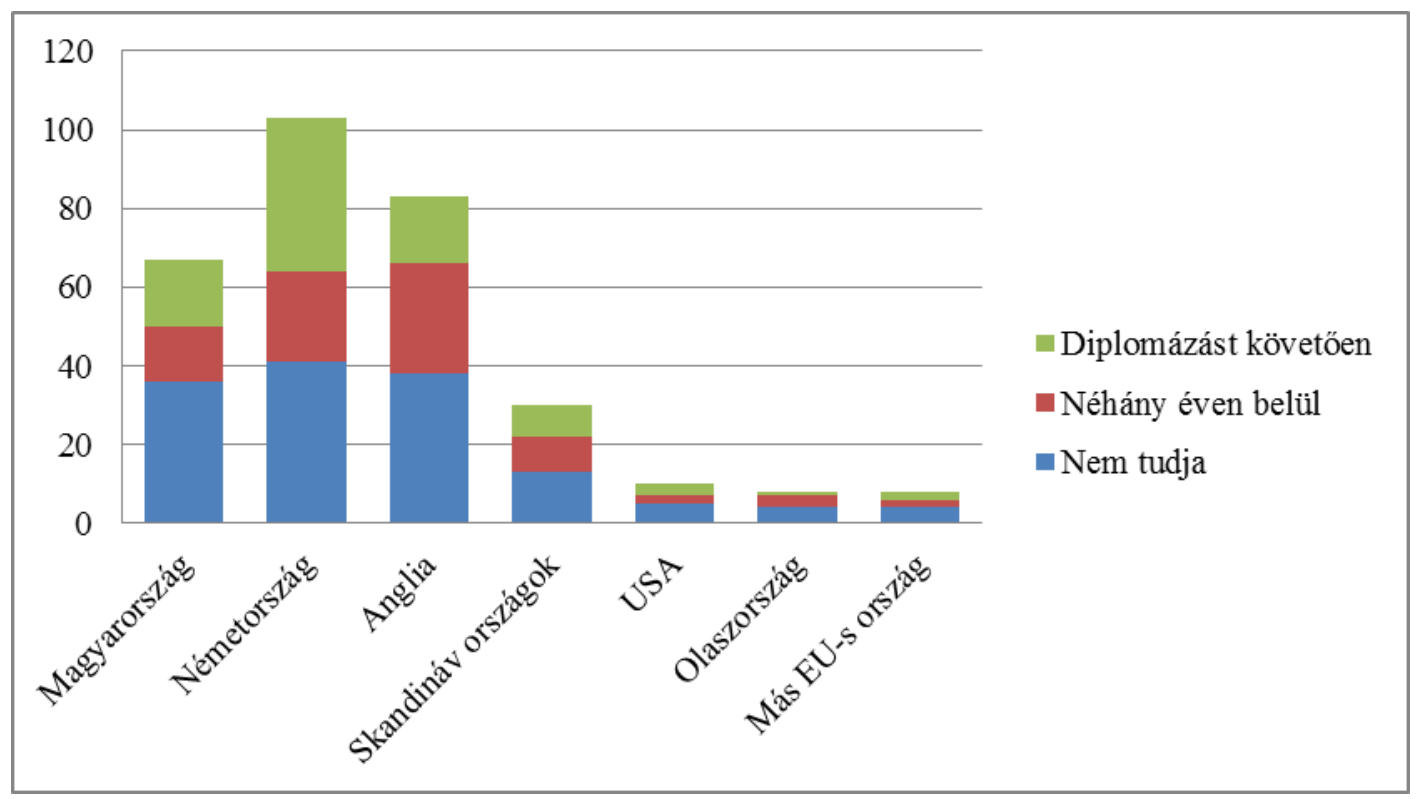

$N($ említések száma $)=309$

A célterület és a vándorlás tervezett időzítése közötti kapcsolat viszont csak Németország esetében szignifikáns $\left(\chi^{2}=8,429\right.$; szig.:0,015). A Németországot (is) választók körében a közvetlenül diplomázás utánra, vagy a rezidens képzésre időzített vándorlást tervezők aránya megközelíti a határozatlanokét; ez utóbbi a legnagyobb hányadot jelenti minden ország esetében $(39 \% \text {, illetve } 40 \%)^{155}$. Ennek hordereje abban áll, hogy az időben közeli és határozott migrációs tervek nagyobb valószínüséggel valósulnak meg, mint az idő távlatába vesző és bizonytalan tervek (Horváth 2003b). Vagyis az amúgy is kedvelt Németországba valószínüleg nagyobb is lesz a munkavállalás és szakképzés céljából megvalósuló migráció. A Magyarországot (is) választók közel felének még nincs konkrét terve arra vonatkozóan, hogy mikor is szeretné a külföldi munkavállalást elkezdeni, továbbá egynegyede már rögtön diplomázás után elkezdené itt a munkavégzést/ tanulást; amely a gyógyszerészek kivételével valamennyi szakot egyformán érint.

\footnotetext{
155 Leggyakoribb válasz a határozatlanság/ bizonytalanság: a legtöbb esetben a „még nem tudom, hogy mikor" válasz dominál. Ez alól Franciaország jelenti az egyik kivételt: az ezt az országot (is) választók többsége néhány évvel a diplomázás után migrálna. A nagyon alacsony az esetszám miatt (5 fö), nem tulajdonítható ennek nagy jelentőség.
} 


\subsubsection{Idegennyelv-ismeret: a humán töke hatásai}

Az angol a legelterjedtebb és leginkább beszélt nyelv (113 fö folyékonyan beszéli, ebböl 49 fö rendelkezik közép- vagy felsőfokú nyelvvizsgával), ezt követi a német nyelv (21 hallgató beszéli, 10 fö rendelkezik nyelvvizsgával); olaszul vagy franciául összesen 8 hallgató beszél, akik közül hárman rendelkeznek középfokú nyelvvizsga bizonyítvánnyal.

Nincs különbség a magukat ,jó” és „közepes” tanulónak vélő hallgatók között a nyelvvizsga bizonyítvánnyal való rendelkezés tekintetében: mindkét csoportnak közel egynegyede rendelkezik felső- vagy középfokú nyelvvizsgával. Másfelől viszont szignifikánsan eltérnek az idegen nyelvek ismerete terén: ugyanis a jó tanulók kétharmada beszél egy idegen nyelvet, a közepes tanulóknak viszont kevesebb, mint fele $\left(\chi^{2}=8,102\right.$; szig.: 0,004). A meghatározó tényező a származás, azaz a szülők társadalmi státusa. Talán nem meglepő, hogy a magas státusú családból jövőkre jellemző leginkább egy idegen nyelv ismerete, és az alacsonyabb státusúakra a legkevésbé.

8. táblázat: Származás hatása az idegennyelv-ismeretre

\begin{tabular}{lcc} 
Szülöi státus & $\begin{array}{c}\text { Nyelvismeret }(\%) \\
\text { Legalább társalgási } \\
\text { szintü }\end{array}$ & Nyelvvizsga (\%) \\
\hline Alacsony $(\mathrm{n}=79)$ & 33 & Bizonyítvánnyal rendelkezik \\
Vegyes $(\mathrm{n}=74)$ & 47 & 12 \\
Magas $(\mathrm{n}=95)$ & 75 & 37 \\
\hline$N=238$ & $\chi^{2}=31,670 ;$ szig:0,000 & $\chi^{2}=17,843 ;$ szig:0,000
\end{tabular}

A legalább társalgási szintü nyelvismeret, illetve a nyelvvizsga bizonyítvány megléte nem erősíti a külföldi munkavállalás tervezését, mert az alacsony szintü idegen nyelvtudással rendelkezők hasonló arányban szándékoznak migrálni, mint a folyékonyan beszélők (60\% és 64\%). ${ }^{156}$ A felső- vagy középfokú nyelvvizsgával való rendelkezés csak Olaszország, az USA és a Skandináv országok esetében látszik lényegesnek: az első országot (is) említők háromötöde, az USA-t (is) jelölők kétötöde, míg a Skandináv országokba vágyók egyharmada rendelkezik nyelvvizsgával; a többi ország esetében ez az arány nem haladja meg a 28 százalékot. Ám amint a korábban közölt táblából leolvasható, ${ }^{157}$ mindössze tízen vagy annál is kevesebben nevezték meg

\footnotetext{
${ }^{156}$ Ellenben a magyarországi hallgatók esetében az idegen nyelvismeret növeli a külföldi munkavállalási szándékot: pl. az angolul folyékonyan beszélők kétötöde (43\%) tervez külföldi munkavállalást, míg a gyenge nyelvismerettel rendelkezőknek csupán egynegyede $\left(\chi^{2}=43,653\right.$; szig:0,000). A bizonytalanokat kihagyva az elemzésből, még hangsúlyosabbá válik a nyelvtudás hatása a migrációs tervekre.

${ }^{157}$ Lásd a 7. táblázatot.
} 
Olaszországot vagy az USA-t. A társalgási szintünek minősített nyelvtudást véve alapul - és nem csak a nyelvvizsga bizonyítvánnyal igazolhatót -, az tapasztalható, hogy a Skandináv országok vonzzák leginkább az idegen nyelvek ismeretével bírókat (79 százaléka beszél legalább egy idegen nyelvet; $\chi^{2}=8,827$; szig.:0,012), illetve Olaszország (75\%). A „más EU-s országokba” és az angol nyelvterületekre igyekvők háromötöde rendelkezik társalgási szintü nyelvismerettel. Viszont a Magyarországot (is) célországként jelölők fele alacsony szintü idegen nyelvtudással rendelkezik és csak egyötödének van nyelvvizsga bizonyítványa; de a Németországba igyekvőknél is nagyon hasonló a helyzet (54 százaléka beszél folyékonyan legalább egy idegen nyelvet vagy/és rendelkezik nyelvvizsga bizonyítvánnyal). Így az a korábban megfigyelt tendencia, hogy a magasabb idegennyelv-ismerettel bírók inkább Nyugat-Európába, a szegényes nyelvtudással rendelkezők pedig inkább Magyarországra szándékoznak menni (Kiss 2012; Örkény 2003), csak részben áll a vizsgált népességre, vagy legalábbis nem különül el élesen egymástól a két csoport. ${ }^{158}$

9. ábra: Idegen nyelvü média fogyasztása és a migráció tervezése közötti kapcsolat (relatív gyakoriságok)

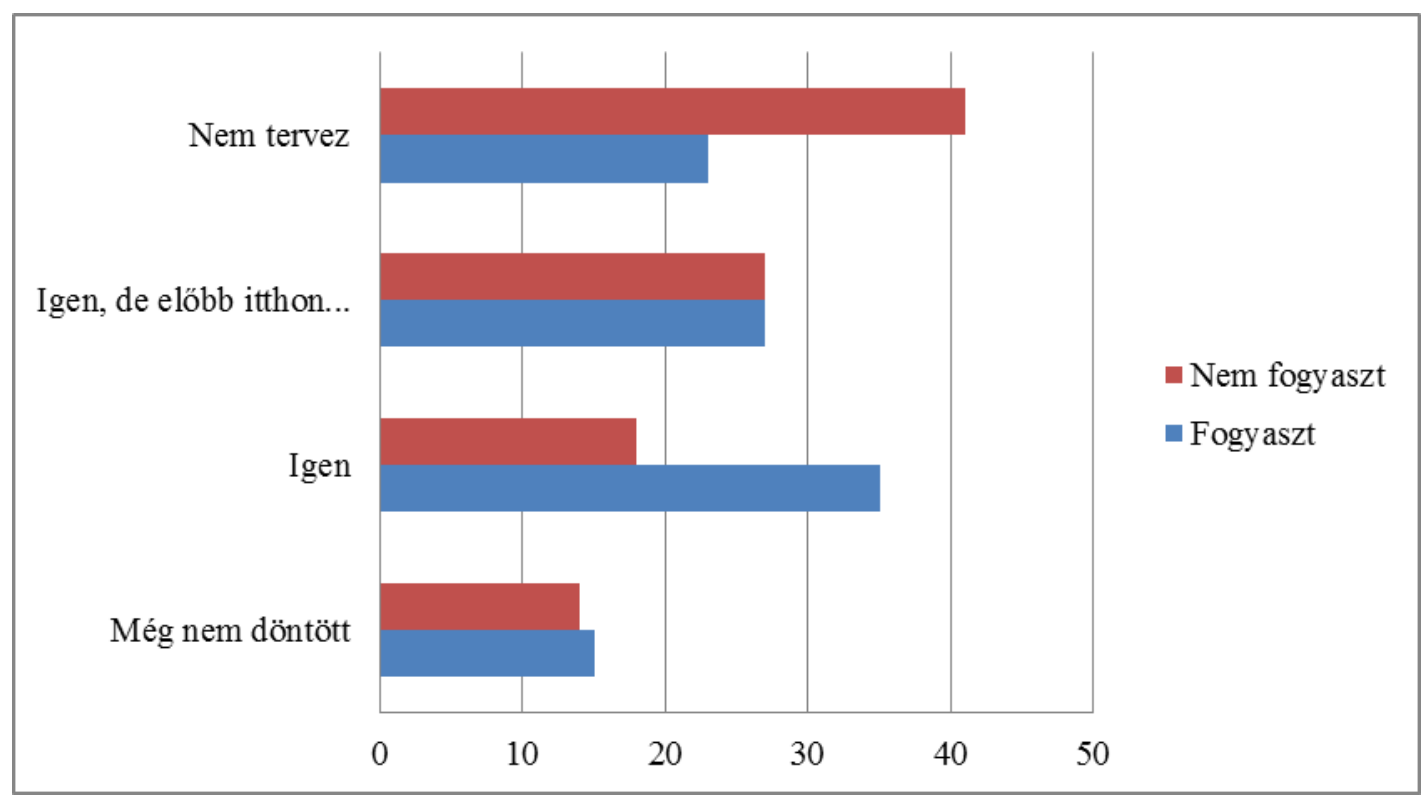

$$
N=248
$$

Szignifikáns azonban az idegen nyelvü média (folyóirat, napilap, rádió, TV) fogyasztása és a migráció tervezése közötti kapcsolat $\left(\chi^{2}=8,949\right.$; szig.: 0,030$)$, bármilyen irányú is legyen okságilag ez az összefüggés. Ez alatt az értendő, hogy valaki tervezheti a külföldi munkavállalást annak következtében, hogy az idegen nyelvü médiát fogyasztva kitágult a referencia tere, illetve olyan ismeretekre tesz szert,

158 Természetesen annak szerepe sem hagyható figyelmen kívül, hogy már egy eleve szelektált, felsőoktatásban tanuló hallgatói népességről van szó. 
amelyek fényében előnyösebbnek vélheti a külföldi munkavállalást. Másfelöl az idegen nyelvü média fogyasztása lehet a migrációs tervek egy következménye, a készülés egy formája; és ilyen esetben a nyelvtanulás, gyakorlás egy formáját is jelentheti. Viszont az idegennyelvü média fogyasztásának gyakorisága már nem függ szignifikánsan össze a migráció tervezésével; jóllehet a vándorlást tervezők gyakrabban néznek/hallgatnak/olvasnak külföldi médiát.

Az elemzés egy további eredménye, hogy várakozásaimmal ellentétben, az idegen nyelvek ismerete kevéssé kapcsolódik a migráns hálózatokban való részvételhez: ahhoz, hogy a megkérdezettnek él-e az adott országban rokona, barátja vagy ismerőse, illetve a kapcsolat típusához.

Megállapítható, hogy a nyelvismeret jelen esetben olyan humán tökeként müködik, amely ugyan nem közvetíti a származás hatását a migrációs tervekre - mivel a magasabb szintű nyelvtudás nem erősíti a külföldi munkavállalás tervezését -, viszont elősegítheti a külföldi munkavállalás szándékának megvalósítását a későbbiekben, mivel szükség esetén bármikor konvertálható.

\subsubsection{Coping potenciál: Attitüdök}

\subsubsection{Helyzet- és jövőkép}

A végzős hallgatók a helyzetüket és jövőjüket érintő kijelentésekre egy ötfokú Likert skálán válaszolhattak ( $1=$ egyáltalán nem ért egyet, $5=$ teljesen egyetért). Az, hogy az egyén milyennek érzékeli és értékeli saját helyzetét és lehetőségeit, befolyásolja szándékait és jövőjét érintő döntéseit (Örkény 2003; Festinger 2000). A felsorolt hat állítás közül kettő a tágabbi környezetükre vonatkozott (romániai fiatalság és az erdélyi magyar kisebbség jövője), egy a nemek közötti megkülönböztetésre (külföldön több esélyük van a nőknek az orvosi pályán); a további három pedig a jövedelemre (kezdő fizetés elégségessége, a hálapénz szükségessége; és egy hipotetikus helyzet: otthon maradna egy nyugati kereset feléért).

Leginkább azzal értettek egyet a hallgatók, hogy az egészségügyi dolgozók kezdő fizetése nem elégséges családjuk eltartásához ${ }^{159}(\mathrm{Mean}=3,94)$; és ugyancsak nagy volt az egyetértés a tekintetben is, hogy a nyugat-európai orvosi/gyógyszerész/nővéri bérek feléért biztosan otthon maradnának (Mean= 3,76). Ezeket követi a magyar kisebbség hátrányosnak ítélt jövőképe (Mean=3,52). A nőket nem látják hátrányos helyzetben az orvosi pályán külföldi kollégáikhoz képest (Mean=2,16), és a nők maguk

\footnotetext{
${ }^{159}$ Romániában egy rezidens orvos bére 800 RON (60.000 HUF) volt a megkérdezés időszakában. Az EU országai között a romániai egészségügyi dolgozók a második legalacsonyabban fizetettek (Reginato, Grosso 2011).
} 
sem tartják annak (Mean= 2,23); bár a pályaválasztásnál vagy a szakterület kiválasztásánál fontos szempont több női hallgató számára, hogy az összeegyeztethető legyen a női/anya szereppel. ${ }^{160}$

A nők kissé borúlátóbbak, de csak a fiatalok jövőjének megítélésében térnek el nagyobb mértékben a férfiaktól, inkább kilátástalannak látva azt (Mean=3,12; férfiak: 2,82; $\mathrm{F}=3,247$; szig.: 0,073); míg a férfiak inkább érzik a megélhetés terhét pályakezdőként (Mean=4,12; nők: 3,90).

10. ábra: Jövővel kapcsolatos attitüdváltozók átlagértékei a hallgatott szak függvényében ${ }^{161}$

Fiataloknak nincs jövője az országban

Magyarok mindig hátrány os helyzetben lesznek Romániában

Külföldön a nöknek nagyobb esélye van egyes szakterületeken elhelyezkedni*

Kezdő orvosként (stb.) otthon az ember képtelen eltartani a családját

Hálapénz szükséges rossz*

Nyugati fizetés feléért biztosan maradna

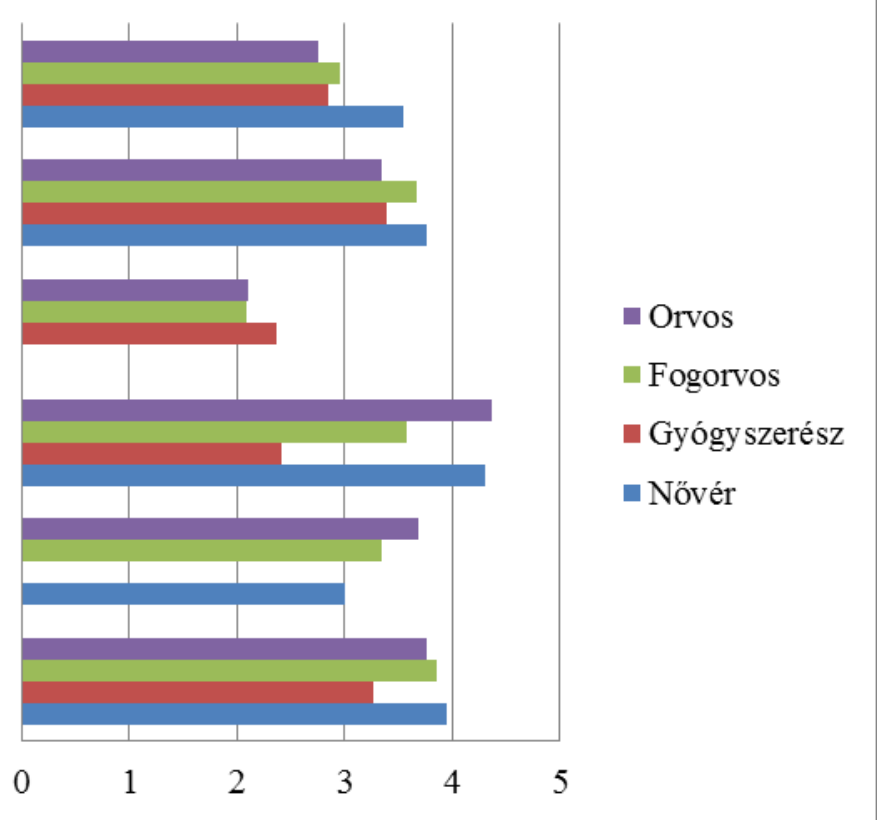

Szakok szerint a nővérek ítélik meg leginkább kilátástalannak a jövőjüket Romániában élő magyarokként (Mean=3,76) és fiatalokként (Mean=3,55; $\mathrm{F}=9,840$; szig.: 0,000), őket követik a fogorvos hallgatók. Leginkább az orvostan- és nővérhallgatók vélik úgy, hogy a kezdő fizetés nem elégséges a megélhetéshez, illetve a gyógyszerészek látják legkedvezőbbnek majdani bérezésüket $(\mathrm{F}=41,533$; szig.: 0,000). A hálapénz szükségességével leginkább az orvosok (Mean=3,69) és legkevésbé a nővérek (Mean= 3,00; $F=7,461$; szig.: 0,001) értettek egyet. Bevallásuk szerint többségüket a magasabb kereset biztosan otthon tartaná; kevésbé igaz ez a gyógyszerész hallgatókra.

\footnotetext{
${ }^{160}$ A női orvostanhallgatók egynegyede számára a szakosodási terület kiválasztásakor a legfontosabb motivációt jelentette, hogy összeegyeztethető legyen női/feleség/anya szereppel. Az is megfigyelhető továbbá - amint az interjúk később rávilágítottak -, hogy elfogadnak általánosan osztott véleményeket és ezáltal ki is zárják választási lehetőségeikböl az olyan szakterületeket, amelyek „férfi szakmáknak” minősülnek. Amint arról D vallott: „, a nagy sebészetek, azok szerintem nem női munkák”, így nem is érzik hátrányosan megkülönböztetve magukat.

161 A női orvosokkal kapcsolatos kijelentést a nővérek, a hálapénzről való megállapítást pedig a gyógyszerészek kérdőíve nem tartalmazta, mivel az ő esetükben nem tartottam relevánsnak.
} 
Saját helyzetük értékelése és a terveik, pontosabban külföldi munkavállalási szándékaikkal közötti összefüggés szemlélteti a következő táblázat.

9. táblázat: Jövőkép és migráció kapcsolata ${ }^{162}$

\begin{tabular}{|c|c|c|c|}
\hline Egyetért az alábbi kijelentéssel & $\begin{array}{l}\text { Tervez külföldi } \\
\text { munkavállalást } \\
\text { (\%) }\end{array}$ & Chi-négyzet & Szig. \\
\hline \multirow{3}{*}{$\begin{array}{l}\text { Fiataloknak nincs jövöje az országban } \\
(\mathrm{n}=83) \\
\text { Magyarok mindig hátrányos helyzetben } \\
\text { lesznek Romániában }(\mathrm{n}=126)\end{array}$} & 72 & 25,703 & 0,000 \\
\hline & \multirow[t]{2}{*}{60} & \multirow[t]{2}{*}{13,645} & \multirow[t]{2}{*}{0,003} \\
\hline & & & \\
\hline $\begin{array}{l}\text { Külföldön a nőknek nagyobb esélye van } \\
\text { egyes } \quad \text { szakterületeken elhelyezkedni } \\
(\mathrm{n}=18)\end{array}$ & 70 & 23,672 & 0,000 \\
\hline Kezdô orvosként (stb.) otthon az ember & \multirow{3}{*}{$\begin{array}{l}68 \\
63\end{array}$} & \multirow{3}{*}{$\begin{array}{c}1,601 \\
6,08\end{array}$} & \multirow{3}{*}{$\begin{array}{l}0,659 \\
0,108\end{array}$} \\
\hline $\begin{array}{l}\text { Keptelen eltartanı a csaladjat }(\mathrm{n}=1 / 2) \\
\text { Hálanénz szïkséges rossz }(\mathrm{n}=105)\end{array}$ & & & \\
\hline $\begin{array}{l}\text { Hálapénz szükséges rossz }(\mathrm{n}=105) \\
\text { Nyugati fizetés feléért biztosan maradna } \\
(\mathrm{n}=146)\end{array}$ & & & \\
\hline
\end{tabular}

Azok a hallgatók, akik szülőhazájukban a - közeli - jövőjüket fiatalként, kisebbségiként és/vagy pályakezdőként bizonytalannak gondolják, nagyobb arányban tervezik a külföldi munkavállalást. Ez a kérdés nem alkalmas annak megválaszolására, hogy hogyan függnek össze oksági szempontból az attitüdök és tervek, de egy sajátos kölcsönhatás van közöttük, amely értelmében a kedvezötlen jövőbeni kilátások nem csak okai a migrációs tervek megszületésének, hanem - amint már említésre került - e terveket alátámasztandó legitimizációs szociálpszichológiai tényezőkként is müködnek. Illetve megfordítva a dolgot: azok a tőke-szegényebb csoportok, akik úgy vélik, hogy nem változtathatják meg állapotukat, a belső konfliktus elkerülése végett megszépítik jövőképüket.

\subsubsection{Méltányosság}

A hallgatóknak a disztributív igazságosságról alkotott elképzelése, vagyis az általuk igazságosnak vélt elosztási elv, valamint a társadalom fenntartásában a saját hozzájárulásuk és a javakból való részesedés mértékéhez való attitűdjük is a vizsgálat tárgyát képezte. A disztributív igazságosságot a következő három elv segítségével vizsgáltam: a hozzájárulással arányos részesedés, az egyenlő elosztás, illetve a szükség szerinti részesedés elvével (Tóth 2012).

A végzősök fele a hozzájárulással arányos részesedést tartja méltányosnak, kétötödük a

${ }^{162}$ A semlegesnek tekinthető 3-as kód (egyetért meg nem is) kihagyásával. 
legjobb képesség szerinti hozzájárulás és szükség szerinti részesedés, míg tizedük az egaliteriánus elosztás elvét vallja. ${ }^{163}$ A hozzájárulás-részesedés arányosságát támogatók átlag felett az orvos, fogorvos, férfi és magas társadalmi státusú családból származó hallgatók. ${ }^{164} \mathrm{Az}$ egyenlőség elvét ezzel éppen ellentétben a gyógyszerész és nővér, női és alacsonyabb illetve vegyes társadalmi státusú családból jövő hallgatók képviselik elsősorban. A „segítse az erős a gyengét” működési elvet támogatók körében átlag feletti arányban vannak jelen szintén a nővérek, nők, alacsony státusú háttérből jövők. ${ }^{165}$

Saját jövőbeli helyzetét a majdani egészségügyi dolgozók többsége nagyon méltánytalannak tartja. A társadalom müködéséhez szükséges kiadásokhoz való hozzájárulásukat és a javakból való részesedésük arányát egy 0 -tól 10-ig terjedő skálán értékelhették, ahol a 0 azt jelentette, hogy sokkal többet kapnak, mint amennyivel hozzájárulnak, míg a 10 ennek az ellentétét, vagyis azt, hogy sokkal többel járulnak hozzá, mint amennyit kapnak. Átlagosan 6,75-nél helyezték el magukat. Az egyenlőség elvét vallók háromötöde ítéli meg úgy, hogy majdani nővérként/ orvosként/ gyógyszerészként többel járul hozzá a társadalom fenntartásához, mint amennyit kap; az arányosságot és a szükség szerinti részesedést támogatóknak pedig közel háromnegyede vélekedik eképpen $\left(\chi^{2}=10,214 ; \quad\right.$ szig.: 0,037). Jövőbeli helyzetüket legméltánytalanabbnak az arányosság elvét helyeslők látják: 43 százalékuk 8-as vagy annál nagyobb értéket jelölt meg a skálán. A gyógyszerészek látják leginkább méltányosnak a helyzetüket, kétharmaduk az 5-ös vagy annál kisebb értéket jelölt (Mean= 5,75), míg az orvosok a leginkább méltánytalannak, fele 8-as vagy annál magasabb értéket jelzett (Mean= 7,16, $\mathrm{F}=5,955$; szig.: 0,001). A majdani méltánytalanságtól való félelem elsősorban a férfi, a 25 éves és annál idősebb, illetve az alacsony meg a magas státusú végzősökre jellemző. Várakozásaimmal ellentétben a méltánytalanul nagynak vélt teherviselés és a migrációs szándék között nincs egy pozitív összefüggés (értsd: minél nagyobbnak véli a hozzájárulás-részesedés aránytalanságát, annál inkább tervezi a migrációt). A többel hozzájárulók háromötöde tervez külföldi munkavállalást, éppúgy, mint az ugyanannyiban vagy többen részesedők. Erre magyarázatként szolgálhat az, hogy azok, akik külföldön szándékoznak munkát vállalni, válaszukban már eleve figyelembe vehették a kedvezőbb béreket, míg az otthon maradni tervezők joggal vélekedhetnek úgy, hogy alacsony

\footnotetext{
${ }^{163}$ Disztribúciós konfliktus esetén a szolgáltató osztálynak a legitimációs ideológiája a meritokrácia: az érdem kritériumát úgy definiálja, hogy tagjainak versenyelőnyét maximalizálja, illetve a formális képzettséget a vágyott munkahelyekre való belépés ellenőrzése eszközeként használja (Goldthorpe 1982). ${ }^{164}$ Valamennyi összefüggés szignifikáns.

${ }^{165}$ Ez tökéletesen követi a szakirodalomban leírt mintázatokat (Tóth 2012).
} 
fizetésükhöz mérten sokkal többet nyújtanak majd. ${ }^{166}$

\subsubsection{Elégedettség}

A hallgatóknak a kapott szakmai képzéssel és eddigi életükkel való elégedettségét mérte. Az első tényező esetében az a kérdés merült fel, hogy a képzéssel való elégedetlenség - az inkompatibilitás érzését szülve - inkább gátolja-e a külföldi munkavállalás tervezését, vagy éppen ellenkezőleg, bátorítja azt, mintegy a szakmai innováció lehetőségével kecsegtetve a vándorlást tervezőt. Az eredmények alapján megállapítható, hogy a végzős évfolyamok hallgatói a képzéssel közepesen elégedettek, ${ }^{167}$ bár szakok szerint szignifikáns eltérés mutatkozik $\left(\chi^{2}=44,633\right.$; szig.: $0,000)$. Leginkább a nővér- és a gyógyszerészhallgatók elégedettek az intézmények által nyújtott szakmai képzéssel (3,24 és 3,22 átlaggal), az orvostan-hallgatók fele közepesen elégedett, és másik fele kiegyensúlyozottan oszlik meg az elégedetlenek és inkább elégedettek között. Legkevésbé a fogorvos hallgatók elégedettek, mindössze két fó jelezte elégedettségét a 8 fö közepesen elégedett és 23 fö elégedetlennel szemben (Mean=2,37). Az elégedetlenség kissé erősítheti a külföldi munkavállalás szándékát: az elégedettek több mint fele tervezi a migrációt, míg az elégedetleneknek kétharmada. Ez az összefüggés viszont nem szignifikáns, még a semlegesnek tekinthető „3”-as kategória figyelmen kívül hagyásával sem.

Nagyobb elégedettség található eddigi életüket tekintve: a 11 fokú skálán $(0$ = nagyon elégedetlen, $10=$ teljesen elégedett) 7,32 az átlag. Kilenc százalék jelölte 4-gyel vagy annál kisebb értékkel az elégedett(len)ségét, míg egynegyede a két legfelső érték valamelyikén. Szakok és nemek szerint nincs jelentős eltérés, bár a férfiak nagyon kevéssel elégedettebbek; hasonlóképpen a magas társadalmi státusú szülők gyermekei is. De szignifikáns eltérés mutatkozik a szülők anyagi helyzete szerint, mely értelmében az eddigi élettel való elégedettséget leginkább a szülők kedvezőbbnek vélt anyagi helyzete befolyásolja. A rosszabb jövedelmi helyzetű családból származók elégedettségi átlaga 6,53; a közepes anyagi helyzetüeké 7,40; míg a szubjektív gazdagoké 7,91 ( $\mathrm{F}=$ 10,590; szig.: 0,000). Mivel mindkét tényező (anyagi helyzet és elégedettség) szubjektív megítélésen alapszik, a kettő közötti összefüggés igazolja és jól tükrözi a relatív depriváció és az elégedettség közötti kapcsolatot (Gödri \& Kiss 2009).

Részben beigazolódni látszik Sikék megállapítása, mely szerint az elégedetlenség ,a migrációs potenciál motorja” (Sik \& Örkény 2003, 191). A nagyon elégedetlenek

\footnotetext{
${ }^{166}$ A migrációt tervezők esetében az átlag 6,74, az inkább maradni szándékozók esetében pedig 7,13; ám a különbség nem szignifikáns.

${ }^{167}$ Az 1-töl 5-ig terjedő skálán, ahol az 1 a nagyon elégedetlent, az 5 pedig a teljesen elégedettet jelzi, az átlag 3,03.
} 
viszont a legkevésbé kedvező anyagi helyzetű családokból származnak, ezért jóllehet a mobilitási szándék bennük is megvan, de nem rendelkeznek a megvalósításukhoz szükséges erőforrásokkal, gazdasági tőkével. Másfelől viszont a nagy mértékü elégedettség a helyben maradási szándékot erősíti (Sik \& Örkény 2003).

11. ábra: Eddigi élettel való elégedettség és a migráció tervezése (relativ gyakoriságok)

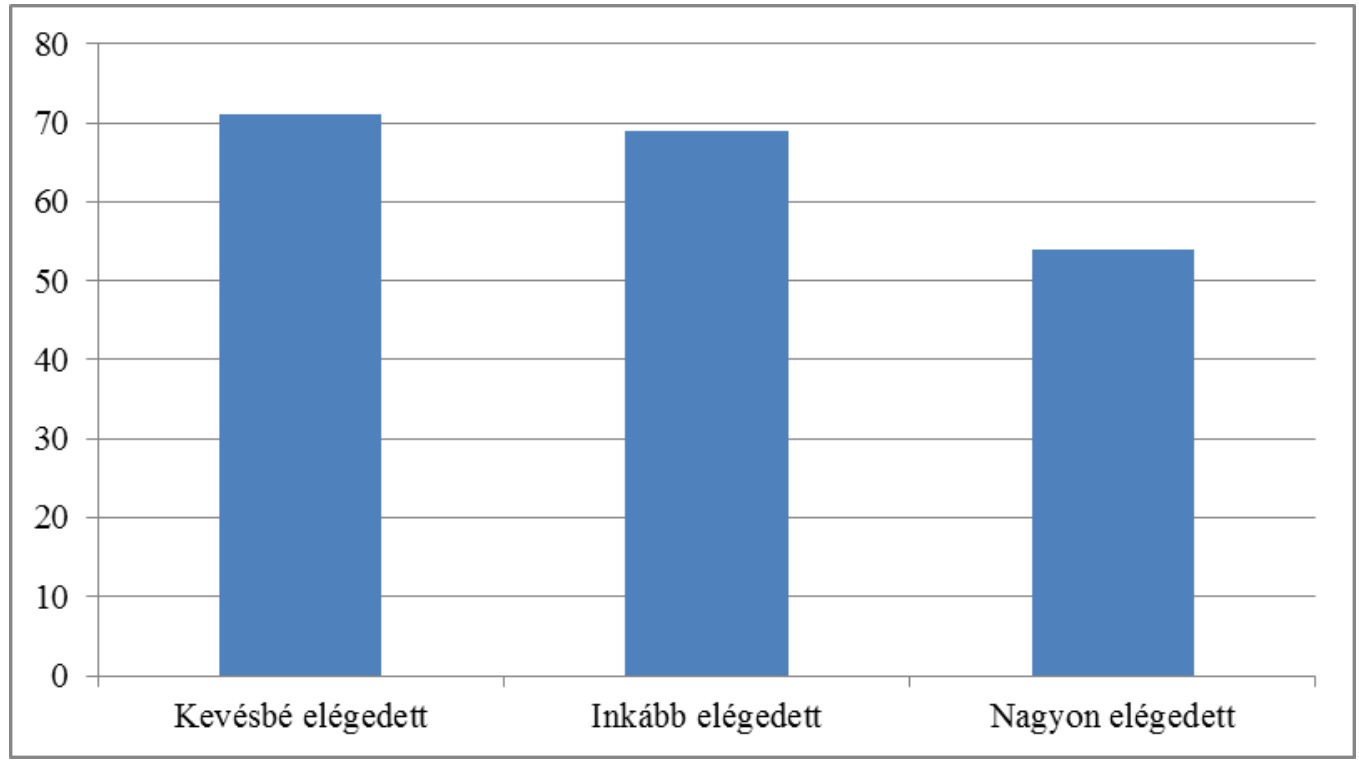

$N=241$

\subsubsection{Motivációk ${ }^{168}$}

A külföldi munkavállalási szándék mögött meghúzódó okokat egy félig zárt kérdés vizsgálta; a válaszlehetőségek között többnyire szakmai okok szerepeltek, melyek a narratív interjúkban is megjelentek, illetve amelyeket a román egészségügyi dolgozók említettek migrációs kutatásokban (Rohova 2011). ${ }^{169}$ Lehetőségük volt a felsoroltakon kívüli motivációk megnevezésérre, majd végül rangsorolniuk kellett az összes motivációt fontossági sorrendben. Ez a rangsor jól tükrözi a migrációhoz füzött várakozásaikat, remélt nyereségeket. A kérdőívben szereplő hat motiváció közül az első négy leggyakoribb a következő volt:

\footnotetext{
${ }^{168}$ A survey egyik korlátja, hogy a motivációk fontosságának mérésekor a korábbi migrációs potenciál kutatásokban alkalmazott kérdéssort - a szakmai push és pull tényezőket - vette csak figyelembe, és nem tartalmazza a narratívákban kulcsszerepet játszó családi/párkapcsolatot és hálózatokat.

${ }^{169}$ Lásd a 7. fejezet következtetéseit.
} 
10. táblázat: A migrációs motivációk rangsora és emlitésük relatív gyakorisága

\begin{tabular}{|c|c|c|c|c|c|}
\hline Migrációs motiváció (\%) & $\begin{array}{c}\text { Elsö } \\
\text { helyen }\end{array}$ & $\begin{array}{c}\text { Második } \\
\text { helyen }\end{array}$ & $\begin{array}{c}\text { Harmadik } \\
\text { helyen }\end{array}$ & $\begin{array}{c}\text { Negyedik } \\
\text { helyen }\end{array}$ & $\begin{array}{c}\text { Összes } \\
\text { emlités } \\
(\%)\end{array}$ \\
\hline A román nyelv problémát jelent & 2 & 2 & 2 & 3 & 8 \\
\hline Magasabb fizetés & 37 & 26 & 20 & 10 & 82 \\
\hline Jobb munkakörülmények & 26 & 34 & 23 & 11 & 80 \\
\hline Több szakmai fejlődési & & & & & \\
\hline $\begin{array}{l}\text { lehetőség } \\
\text { Magasabh életszínvonal }\end{array}$ & $\begin{array}{c}25 \\
7\end{array}$ & $\begin{array}{l}23 \\
10\end{array}$ & 21 & $\begin{array}{l}19 \\
40\end{array}$ & $\begin{array}{l}75 \\
71\end{array}$ \\
\hline $\begin{array}{l}\text { Magasabb életszinvonal } \\
\text { Nagyobb szakmai presztízs }\end{array}$ & $\begin{array}{l}7 \\
2\end{array}$ & $\begin{array}{c}10 \\
4\end{array}$ & $\begin{array}{c}26 \\
8\end{array}$ & $\begin{array}{l}40 \\
16\end{array}$ & $\begin{array}{l}71 \\
26\end{array}$ \\
\hline Egyéb (pl. család) & 1 & 1 & & 1 & 2 \\
\hline$N$ & 223 & 213 & 212 & 211 & \\
\hline
\end{tabular}

Összességében a jobb munkakörülmények pull hatása megközelíti a magasabb bérezését.

A külföldi munka tervezése eltérő okokból történhet a különböző szakterületeken.

12. ábra: Migrációs motivációk relatív gyakorisága a hallgatott szak alapján

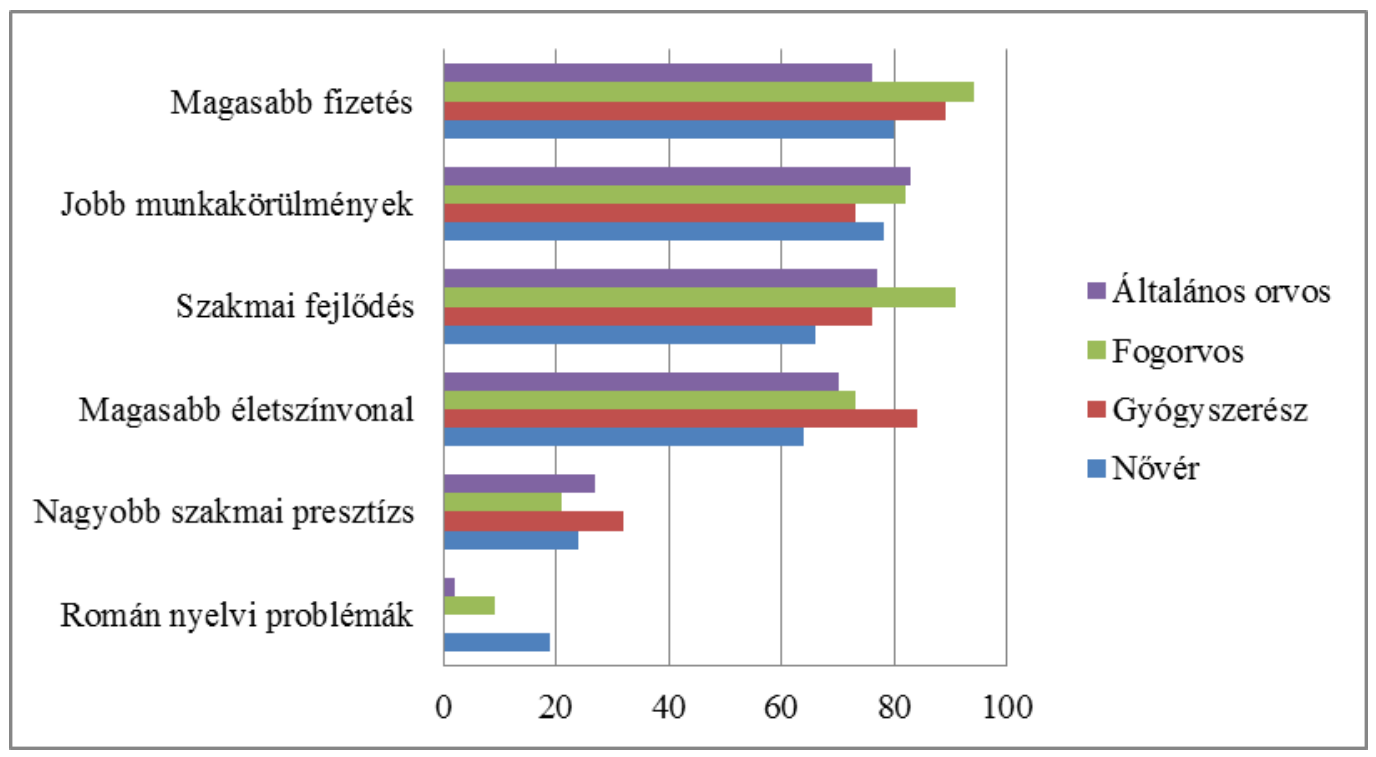

$N=198$

A külföldön megszerezhető magasabb fizetés főként a fogorvos és gyógyszerész hallgatók számára $\left(\chi^{2}=7,262\right.$; szig.: 0,064), a jobb munkakörülmények leginkább az orvostan és fogorvos hallgatók, a több szakmai fejlődési lehetőség a fogorvos hallgatók $\left(\chi^{2}=8,137\right.$; szig.: 0,043), a magasabb életszínvonal és magasabb szakmai presztízs elsősorban a gyógyszerészek, míg a román nyelvi problémák főként a nővér és valamennyire a fogorvos hallgatók számára jelent motivációt a külföldi munkavállalásra. Nemek szerint nem találunk szignifikáns különbséget: a nők nagyobb 
hányada számára motiváló a külföldön elérhető fizetés (83 százalékuk említi az első négy ok között, míg a férfiak 76 százaléka). A más országokban elérhető szakmai fejlődés inkább a férfiak, a magasabb életszínvonal inkább a nők számára motiváló. A családi állapot hatásáról elmondható, hogy a házasok különböznek a többiektől jóllehet számuk kevés -: minden tényező kevésbé motiválja őket, mint egyedülálló, párkapcsolattal rendelkező vagy együtt élö kollégáikat, a román nyelvi nehézségek kivételével. A szülök anyagi helyzete nem, viszont társadalmi státusa összefügg a végzősök motivációival. A magasabb fizetés főként a magas és vegyes státusú szülők gyermekei számára jelent indítékot a vándorlásra $\left(\chi^{2}=8,904\right.$; szig.: 0,012); ${ }^{170}$ továbbá a magas státusú családból származók remélik leginkább a jobb munkakörülmények és a szakmai fejlődési lehetőségek javulását a migrációtól, ${ }^{171}$ míg a vegyes státusúak a migrációtól egyben a felfele való mobilitást is várják: a nagyobb szakmai presztízs náluk jelenik meg leggyakrabban. A hazai intézmények által nyújtott szakmai képzéssel kevésbé elégedettek terveznek inkább külföldi munkavállalást magasabb fizetés és több szakmai fejlődés/tanulási lehetőség céljából.

13. ábra: A szakmai képzéssel való elégedettség és a migráció okai közötti összefüggések (relativ gyakoriságok)

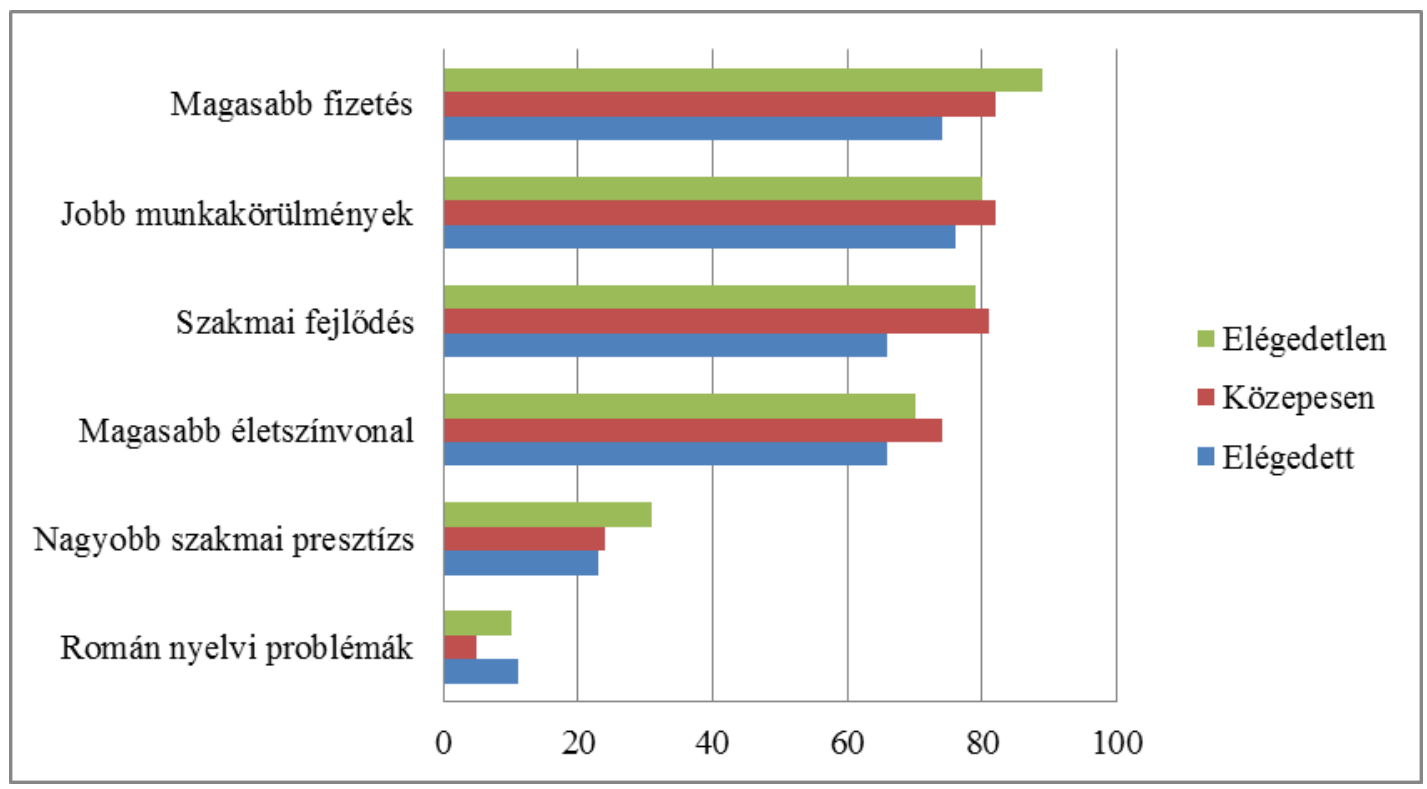

A különböző országok eltérő motiváltságú embereket vonzanak. A jobb munkakörülmények által motiváltak átlag fölött említették Magyarországot $\left(\chi^{2}=5,058\right.$; szig.: 0,025) és a Skandináv országokat. A szakmai fejlődésért vándorlók körében népszerü Anglia és más, nem EU-s országok. A magasabb életszínvonal elérésére

${ }^{170}$ A relatív depriváció vagy az attól való félelem valóban generálhatja migrációs tervek megszületését (Kiss \& Csata 2004).

${ }^{171}$ Ez alátámasztja a szülők foglalkozásának hatása kapcsán, a státusmegőrzésről levont következtetést. 
törekvők az angol nyelvterületeken (USA, Anglia) vállalnának munkát, míg a román nyelv nehézségeivel küzdők elsősorban Németországba vagy Angliába vándorolnának. A nagyobb szakmai presztízs megszerzésére vágyók ugyancsak Németországot választanák, vagy Angliát, Magyarországot. Szignifikáns kapcsolat viszont csak a magasabb fizetés és a két legkedveltebb célország, azaz Németország $\left(\chi^{2}=3,988\right.$; szig.: $0,046)$ és Anglia ( $\chi^{2}=5,340$; szig.: 0,021) között található.

A kulturális integrálatlanság elméletéből kiindulva (Kiss \& Csata 2004) és eddigi eredményekre támaszkodva azt feltételeztem, hogy azon hallgatók, akiknek problémát jelent a román nyelv mindennapos használata, inkább Magyarországot választják célországként (Gödri \& Kiss 2009), de ez a feltevés nem igazolódott be. A román nyelvvel küszködők is nagyobb arányban jelölték meg Németországot és Angliát (is), mint az anyaországot (jóllehet az alacsony esetszám miatt óvatosan kell ezt az összefüggést kezelni). ${ }^{172}$

\subsection{6. Összkép a befolyásoló tényezőkről: a logisztikus regresszióelemzés eredményei}

A külföldi munka tervezését az eddigiek alapján befolyásolni látszó tényezők hatását logisztikus regresszió elemzéssel is megvizsgáltam, ${ }^{173}$ amely módszer segített az eddig kis töredékekben látott képet egységében szemlélni és a a migráció tervezését leginkább befolyásoló tényezőket megállapítani. ${ }^{174}$

11. táblázat: A nyers migrációs potenciált befolyásoló tényezők (a logisztikus regresszió esélyhányadosai)

\begin{tabular}{|c|c|c|}
\hline Magyarázó változók & $\begin{array}{c}1 . \\
\text { modell }\end{array}$ & $\begin{array}{c}\text { 2. modell } \\
* * *\end{array}$ \\
\hline Társadalmi státus & & \\
\hline Alacsony & 1,775 & 2,593 \\
\hline Vegyes (ref.) & & \\
\hline Magas & $2,056^{*}$ & 1,741 \\
\hline
\end{tabular}

\footnotetext{
${ }^{172}$ Hasonló arányban jelölték meg a román nyelvi problémát a legalább egy idegen nyelvet folyékonyan beszélők és a gyengén beszélők.

${ }^{173} \mathrm{Az}$ alacsony esetszám miatt a migrációt tervezők különböző kategóriát egybe kellett vonni, így maradt a tervezi- nem tervezi dummy változó (a határozatlanok kihagyásával). Ez viszont nem csak az árnyalatnyi különbségek elillanását, hanem sok esetben az ezekből fakadó szignifikáns összefüggések megszünését is eredményezte. Másfelől - ugyancsak az alacsony esetszám miatt - a regresszió elemzésben szereplő magyarázó változók számát a lehető legkisebbre kellett redukálni, így a kereszttábla elemzések során szignifikánsnak bizonyuló tényezők sem mind szerepelnek benne.

${ }^{174}$ A minta alacsony esetszámára való tekintettel óvatosság szükséges az eredmények értelmezésékor és a következtetések levonásakor.
} 


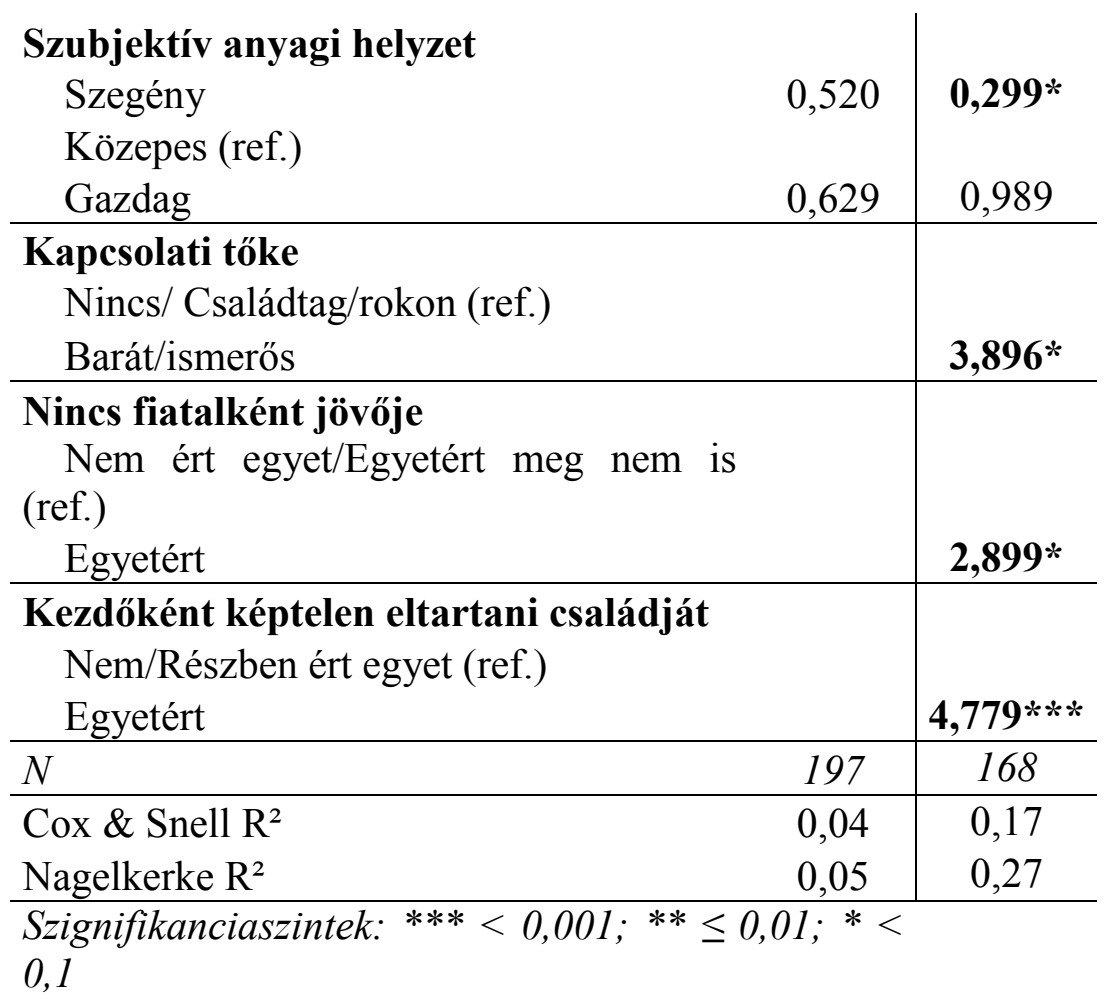

Az első modell a korábbi kereszttáblás elemzések nyomán szignifikáns hatásúnak bizonyult szociodemográfiai tényezők közül a családi társadalmi státust és a szubjektív anyagi helyzetet tartalmazza. A magas társadalmi státusú családokból jövők körében a külföldi munkavállalás tervezésének esélye kétszerese a vegyes státusú családok gyermekeiéhez képest. Az anyagi háttér nem látszik befolyásolni a migráció tervezésének esélyét ebben a modellben.

A második modell a szociodemográfiai tényezőkön kívül a migráns kapcsolati tőkét és attitüd tényezőket is magába foglal. Legnagyobb hatást a kezdő fizetés elégtelennek ítélése gyakorol: majdnem ötször nagyobb eséllyel tervezik a migrációt azok a végzősök, akik egyetértenek azzal, hogy képtelenek lennének családjuk eltartására pályakezdőként, mint az ezzel egyet nem értők. Azok a hallgatók, akiknek a célországban él/ tartózkódik barátja vagy ismerőse, közel négyszer nagyobb eséllyel tervezik a külföldi munkát, mint célszeméllyel nem rendelkező társaik. Ugyancsak megnöveli a migráció tervezésének esélyét a kilátástalannak vélt jövő: majdnem háromszor nagyobb eséllyel tervez migrációt egy olyan hallgató, aki úgy látja, hogy szülőföldjén a fiatalok számára nincs jövő, mint az a végzős, aki optimistán szemléli jövőjét. Viszont a kapcsolati és attitűd tényezők bevonásával megváltoznak a szociodemográfiai tényezők hatásai: az alacsony társadalmi státus növeli inkább a migráció tervezését, viszont ez a hatás nem szignifikáns. Ennek ellenében hat az átlagosnál rosszabb anyagi helyzet, amely viszont szignifikáns módon, nagyon lecsökkenti a külföldi munkavállalás tervezésének esélyét. Tehát itt is visszaigazolódni 
látszik a felfelé mobilitás és anyagi helyzet kapcsán tett korábbi megállapítás, mely értelmében a bőségesebb anyagi tőkével való rendelkezés egyszerre válik a felfelé mobilitás és a földrajzi mobilitás tervezésének forrásává és eszközévé. ${ }^{175}$

Összességében elmondható, hogy a magyar nyelven tanuló hallgatók nyers migrációs potenciálját legerőteljesebben az attitűd tényezők és a migráns hálózat befolyásolja: szignifikánsan növeli a külföldi munkavállalás szándékát a kezdőfizetés elégtelennek ítélése, a célországgal összekötő kapcsolati tőke (ott élő barát) és a kilátástalannak vélt jövő képe. ${ }^{176}$ Csökkenti viszont a migráció tervezésének esélyét a család átlagosnál rosszabb anyagi helyzete; a magas társadalmi státusnak esélynövelő hatása a migráció tervezésében viszont a többi tényező bevonásával megszünik.

\subsection{Tisztított migrációs potenciál}

A 147 hallgatónak, akik tervezik a külföldi munkavállalást, egyharmada (48fö) még csak gondolkodott a migráción, és a megkérdezés időpontjáig még semmit nem tett szándéka megvalósítása érdekében. Ez részben magyarázható a migrációt később tervezők („előbb otthon próbálkozók”) jelentős hányadával (27\%). Tehát a külföldi munkavállalást tervező végzős hallgatóknak majdnem fele a döntés fázisában van, és még nem lépett át a második szakaszba, amely a migrációhoz szükséges feltételek megteremtését jelenti (Horváth 2003b). Ezt igazolja, hogy az időzítés tekintetében nagyon magas a határozatlanok aránya (46\%), és egynegyedük tervezi a migrációt közvetlenül a diplomázás utánra. A fennmaradó hányad néhány év tapasztalatszerzés után (nővérek és gyógyszerészek esetében) vagy a rezidens képzés időszaka alatt (11\%), esetleg már szakvizsgát szerzett orvosként vállalna munkát külföldön. Másfelől viszont ismert, hogy sokkal kisebb valószínüséggel valósul meg a csak elméleti síkon, a tervek szintjén létező migrációs szándék (Horváth 2003b). Tisztított migrációs potenciálnak tehát azt a 115 hallgató ${ }^{177}$ (a tervezők 62 százaléka, az összes hallgató 46 százaléka) tekinthető, akik valamilyen lépés(eke)t tettek a külföldi munkavállaláshoz. Ezek a következök voltak:

\footnotetext{
${ }^{175}$ A kért óvatossággal szükséges kezelni ezt a megállapítást is, hiszen a második modellben a társadalmi státus hatása már nem szignifikáns.

${ }^{176}$ Hasonló hatást fejt ki az erdélyi magyarok helyzetének megítélése. Mivel szorosan összefügg a kettő, a logisztikus elemzés csak egyik változó használatát fogadta el; e tényező mellett pedig a referenciacsoporttal való összehasonlíthatóság mellett döntöttem.

${ }^{177}$ A válaszmegtagadók miatt nem adja ki a még csak gondolkodókkal együtt a teljes összeget.
} 
12. táblázat: Megtett lépés(ek) a migrációs terv megvalósitása érdekében

\begin{tabular}{lc} 
Tett lépés & $\%$ \\
\hline Személyes kapcsolatain keresztül érdeklödött & 46 \\
Interneten gyüjtött információkat & 25 \\
Álláshirdetéseket nézegetett & 19 \\
Személyesen körülnézett külföldön & 5 \\
Elkezdte tanulni a nyelvet & 2 \\
Jelentkezett állásra/ interjúra megy & 1 \\
Egyéb & 3 \\
\hline
\end{tabular}

Megj.: Több válaszlehetőség is megjelölhető volt.

Amint arra már többször is utalás történt korábban, a személyes kapcsolatok fontos információs csatornákként is müködnek, de milyen más források állnak rendelkezésre, illetve melyeket vett vagy venne igénybe, azt egy külön kérdéssel vizsgálta. ${ }^{178} \mathrm{~A}$ személyes kapcsolatok révén való informálódást az internetről való tájékozódás követi; nagy számban (95 hallgató említette) vennék igénybe munkaerő-közvetítő iroda segítségét, illetve a levelezőlistára érkező e-mailekből is tájékozódhat, értesülhet álláshirdetésekről a potenciális munkavállaló.

Többváltozós elemzés vizsgálta a nyers migrációs potenciál esetében oly fontos tényezők hatását, kiegészítve néhány más - csakis a tisztított migrációs potenciál esetében releváns - változóval.

13. táblázat: A tisztitott migrációs potenciált befolyásoló tényezök (a logisztikus regresszió esélyhányadosai)

A külföldi munkavállalás tervezésének esélye: $\operatorname{Exp}(B)$

\begin{tabular}{|c|c|c|c|}
\hline Magyarázó változók & $\begin{array}{c}1 . \\
\text { modell }\end{array}$ & $\begin{array}{l}2 . \\
\text { modell } \\
*\end{array}$ & 3. modell \\
\hline $\begin{array}{l}\text { Társadalmi státus } \\
\text { Alacsony } \\
\text { Vegyes (ref.) } \\
\text { Magas }\end{array}$ & 0,765 & 0,678 & 0,694 \\
\hline $\begin{array}{l}\text { Szubjektív anyagi helyzet } \\
\text { Szegény } \\
\text { Közepes (ref.) } \\
\text { Gazdag }\end{array}$ & 0,864 & 0,946 & 1,159 \\
\hline $\begin{array}{l}\text { Kapcsolati tőke } \\
\text { Nincs/ Családtag/rokon (ref.) } \\
\text { Barát/ismerős }\end{array}$ & & $2,641 * *$ & $2,642 *$ \\
\hline
\end{tabular}

${ }^{178} \mathrm{Ez}$ is többválaszos kérdésként szerepelt. 


\section{Nincs fiatalként jövője} (ref.)

Nem ért egyet/Egyetért meg nem is

\begin{tabular}{l} 
Egyetért \\
\hline Kezdőként képtelen eltartani családját \\
Nem/Részben ért egyet (ref.) \\
Egyetért \\
\hline Motiváció \\
Szakmai tanulás/fejlődés \\
Időzítés \\
Még nem tudja/ Néhány év múlva \\
(ref.)
\end{tabular}

\begin{tabular}{lc|c|c}
\multicolumn{1}{c|}{} & & $\mathbf{2 6 , 6 0 7 * * *}$ \\
\hline$N$ & 211 & 204 & 204 \\
\hline Cox \& Snell R ${ }^{2}$ & 0,01 & 0,08 & 0,32 \\
Nagelkerke R $^{2}$ & 0,01 & 0,11 & 0,42 \\
\hline
\end{tabular}

Szignifikanciaszintek: $* * *<0,001 ; * * \leq 0,01 ; *<$

0,1

Lényeges változások tapasztalhatók egyes tényezők szerepét tekintve a nyers migrációs potenciál modelljeihez képest. Az első, szociodemográfiai modell nem is szignifikáns, vagyis a tisztított migrációs potenciált a származás, illetve a szülői család anyagi helyzete nem befolyásolja.

A kapcsolati tőke és jövőképpel kapcsolatos attitüdök tényezőit is magába foglaló második modell megerösíti a migráns hálózatok és majdani kereset fontosságát a tisztított migrációs potenciál esetében is. A célországban „gyenge” migráns kapcsolattal rendelkezők (Granovetter 2010) - beleértve a kollegiális, baráti viszonyokat is - két és félszer akkora eséllyel tettek már valamit külföldi munkavállalásuk megvalósítása érdekében, mint a kapcsolati tőkét nélkülözők, illetve az „erős” migráns kapcsolattal bírók. ${ }^{179}$ A nyers migrációs potenciál esetében fontos szerepet játszó jövőkép-észlelés szignifikáns hatása már nem érvényesül a tisztított potenciál esetében. A pályakezdőként az anyagi nehézségektől - a fizetés elégtelenségétől - való félelem még az az attitűd, amely a migrációs tervek megvalósítására ösztönzi a hallgatókat. Ebből az következhetne, hogy a külföldön megszerezhető magasabb fizetés növeli annak valószínűségét, hogy a hallgatók már tettek valamit a migráció előkészítése érdekében. Érdekes módon viszont a külföldön elérhető magasabb fizetés nem hat szignifikánsan a tisztított migrációs potenciálra. ${ }^{180}$

A tisztított migrációs potenciál vizsgálatát egy harmadik modell is segíti, amely

\footnotetext{
${ }^{179}$ Granovetter nagy hangsúlyt fektet a gyenge kötéseknek a munkahelykeresésben játszott szerepének elemzésére (Granovetter 2010).

${ }^{180}$ Ezért ki is hagytam a modellből $(\operatorname{Exp}(B)=0,839$; szig.: 0,877).
} 
a korábbiakhoz képest két újabb tényezővel bővült (ezek nem relevánsak a nyers migrációs potenciál esetében): a migráció tervezett időzítésével és a szakmai fejlődés motivációjával. ${ }^{181}$ A migráció várható megvalósításának időbeli közelsége nagyon megnöveli a külföldi munkavállalás érdekében tett lépések esélyét (huszonhatszor nagyobb eséllyel tettek már valamit azok, akik közvetlenül diplomázás után mennének, mint akiknek még nincs konkrét terve az időzítést illetően). A kezdő fizetés elégtelenségétől való félelem esélynövelő hatása megszűnik, viszont a baráti migráns hálózatoké megmarad. A migrációra serkentő okok közül egyedül a szakmai fejlődés motivációja növeli - háromszorosára - a külföldi munkavállalás előkészítésének esélyét.

Összefoglalásként megállapítható, hogy a tisztított migrációs potenciált legerőteljesebben a migráció megvalósításának időbeli közelsége, továbbá a külföldön elérhető jobb szakmai fejlődés reménye, a célországgal összekötő baráti migráns hálózat, valamint a pályakezdő bérek szükösségétől való félelem növeli. Mindez alátámasztja a narratívák kapcsán tett megállapítást, miszerint a rövid távon való gondolkodás (a közvetlen jövőt érintő döntések) és a migráns hálózatok (kapcsolati tőke) szerepe kulcsfontosságú a migráció tervezésében, megvalósításában. Továbbá a szakmai motiváltság és a bérek szükösségétől való félelem szintén említésre kerültek a narratív interjúkban, illetve a romániai migráns egészségügyi dolgozók esetében is a legfontosabb, a külföldi munkavállalást kiváltó tényezők (Rohova 2011; Glinos et al. 2011).

\subsection{Ellen-motivációk, azaz helyben tartó tényezők}

Ezt két kérdés vizsgálta, melyek közül az egyik arra irányult, hogy a külföldi munkát nem tervezők miért döntenek inkább a helyben maradás mellett, illetve a migrációt tervezők számára milyen érzelmi, ideológiai stb. tényezők jelentenek akadályt, visszahúzó erőt. A másik kérdés csak a külföldi munkát vállalni szándékozókat érintette: három olyan feltételt/külső adottságot kellett megnevezniük, amelyek megváltozásával hajlandóak lennének az otthon maradásra.

\footnotetext{
${ }^{181}$ A motivációk közül ez az egy függött össze szignifikánsan a külföldi munkavállalás érdekében már megtett lépésekkel.
} 


\subsubsection{Visszatartó erök}

14. táblázat: Helyben tartó tényezök

\begin{tabular}{lc} 
& Említés gyakorisága (\%) \\
\hline Család & 30 \\
Szülőföld szeretete & 26 \\
Otthon is meg lehet élni, szerettei közelében & 23 \\
Jó szakember otthon is érvényesül & 13 \\
Kisebbségi magyarság iránt érzett felelősség & 5 \\
Már tudja hol fog otthon dolgozni & 4 \\
\hline
\end{tabular}

$N$ (emlitések száma) $=317$

Megj.: Több tényezö is megjelölhetö volt.

A hazához, szülöföldhöz való kötődés a második leggyakrabban említett visszatartó erö. Míg az ezredforduló környékén az erdélyi magyar társadalom tagjai számára a szülőföldön maradás volt a legfontosabb visszatartó tényező, idővel fokozatosan a család vette át a helyét (Gödri \& Kiss 2009), mely a „mi” közösség háttérbe szorulására utal (Sik \& Örkény 2003). Értelmezésemben, és szándékom szerint, a sorban harmadik helyet elfoglaló „otthon is meg lehet élni, és közel vannak azok, akiket szeretek” válaszlehetőség tulajdonképpen értelmezhető úgy is mint a család és szülöföld együttes választása, amikor a jobb anyagi helyzet ellenében inkább a családja körében maradás mellett dönt az egyén. Mivel ebben a válaszlehetőségként megfogalmazott kijelentésben legalább annyira hangsúlyos a család, mint a szülőföld szerepe, ezért nem vélem úgy, hogy ez változtatna a család-szülöföld fontossági sorrendjén.

A szülőföld iránti szeretet és a kisebbségi magyarok iránt érzett kollektív felelösségtudat leginkább az orvostan- és fogorvos hallgatók számára jelent visszatartó tényezőt. Főként az orvosi szak végzősei gondolják úgy, hogy „,a jó szakember otthon is érvényesül”; a fogorvos és gyógyszerészhallgatók némelyikének van már állása (vagy legalábbis ígérete rá) otthon; illetve a nővérek helyeslik legkevésbé azt a megállapítást, hogy szakmájukat gyakorolva otthon is meg tudnak élni (23 százalékuk, míg más szakokon 41-45 százalék). A férfiak minden tényezőt nagyobb arányban neveztek meg, kivéve a családot, amely a nők számára a legfontosabb helybentartó tényező. Másfelől a család, értelemszerủen, legfőképpen a házasok esetében jelent visszatartó erőt. A magasabb társadalmi státussal való rendelkezés összefügg a szülőföld szeretetével, a kisebbségi magyarok iránt érzett felelősség vállalásával. ${ }^{182} \mathrm{Az}$ alacsonyabb státusú szülök gyermekei viszont nagyobb arányban vélik úgy, hogy otthon is meg lehet élni

${ }^{182}$ Ez utóbbi összefüggést nem erősítik meg az interjúk. Inkább az alacsony és vegyes státusú, szűkös gazdasági tőkével rendelkezők fogalmaztak meg a családjuk vagy tágabb környezetük iránt érzett felelősségérzetet. 
egészségügyi dolgozóként, miközben családjuk közelségét sem kell feladniuk. Megfigyelhető, hogy a szülőföldhöz ragaszkodók inkább választják Magyarországot, ami utalhat akár arra, hogy ideológiailag a kettő (azaz Erdély és Magyarország) összetartozik számukra ${ }^{183}$; vagy lehet ennek egy másik, a földrajzi közelséggel magyarázható oka is.

\subsubsection{A maradás feltételei}

A neoklasszikus közgazdaságtan mikro elmélete szerint a migrációs döntés az egyén költség-haszon számításán alapul (Massey et al. 1993; Portes 1995; Castles \& Miller 2009). A döntés mechanizmusa és a számításba vett vagy nem tudatos, ám a döntést befolyásoló tényezők ennél jóval összetettebbek, ${ }^{184}$ de kétségkívül a haszon (akár gazdasági, akár társadalmi vagy pszichikai) mérlegelése is szerepet játszik benne.

\section{4. ábra: A maradás feltételeiként leggyakrabban megnevezett tényezök}

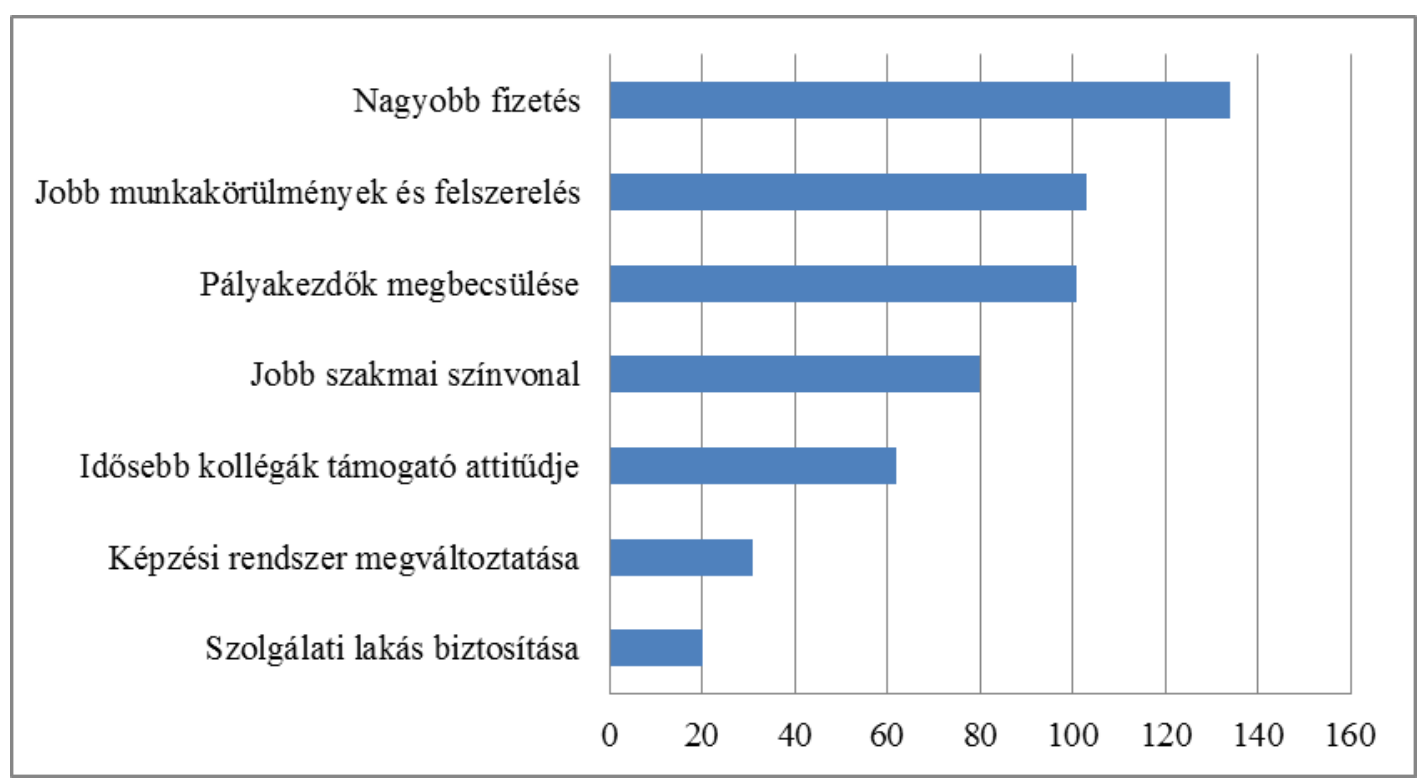

Összes emlités száma $=531$

A kérdőívben felsorolt otthon maradásra késztető tényezők közül a magyar tannyelvü végzősök a következő hármat jelölték meg leggyakrabban: a magasabb bérek biztosítását (58 százalékuk említette), a hazai egészségügyi rendszer munkakörülményeinek és a rendelkezésre álló felszerelés javítását (45\%), illetve a kezdő orvosok/ fogorvosok/ gyógyszerészek és nővérek nagyobb megbecsültsége a hazai (kibocsátó) társadalom részéről (44\%). Ezek nagy hasonlóságot mutatnak a

\footnotetext{
${ }^{183}$ A magyar állam retorikája nyíltan vállalta a határain túl élő magyarokkal való egységet, saját nemzete tagjainak nyilvánítva őket (Fox 2003).

${ }^{184}$ Scott javaslatában a középosztály nemzetközi vándorlása mint egy akár tudatosan, akár anélkül alkalmazott sajátos mobilitási stratégiaként kezelendő, amelyben egyaránt felhasználják társadalmi, kulturális és gazdasági tőkéjüket (Scott 2006).
} 
magyarországi rezidens orvosok és a romániai orvosok körében tapasztalható motivációkkal (Eke et al. 2009; Glinos et al. 2011), illetve a migráns orvosokkal készített interjúkban említett okokkal. Továbbá többnyire megegyeznek a migráció tervezésének okaiként megnevezett főbb pull tényezőkkel, azzal a különbséggel, hogy ez utóbbi esetében a harmadik leggyakrabban megjelölt okként a külföldön elérhető több szakmai lehetőség szerepelt és nem a presztízs.

A nagyobb fizetés főként az orvosokat, nővéreket és gyógyszerészeket ösztönözné a maradásra, a jobb munkakörülmények és felszerelés biztosítása valamennyiük számára egyformán igény, míg a nagyobb megbecsültség átlag fölött a nővérek esetében bizonyulna hatásos eszköznek az otthon maradásra bírás érdekében. Az óhajtott fizetés nagysága szakonként a következő: legmagasabb fizetést a gyógyszerészhallgatók neveztek meg, átlagosan ${ }^{185} 4000$ RON (kb. $900 €$ ), az orvostan-hallgatók 2500 RON (kb. $580 €$ ), a fogorvos hallgatók $2100 \mathrm{RON}$ (kb. 480 ), a nővérek pedig $1500 \mathrm{RON}$ (kb. $350 €)$ (kezdő) fizetésért volnának hajlandók az országban maradni. A szakmai színvonal javítását egyharmaduk, az idősebb kollégák támogató attitűdjét egynegyedük említette. A magasabb szakmai színvonal biztosítása föként a fogorvos, gyógyszerész és orvostan- hallgatók, a szakmabeliek attitüdjének megváltozása pedig az orvostan- és fogorvos hallgatók esetében erősítené a helyben maradás szándékát. A képzési rendszer jelenlegi müködési módjának megváltoztatását és szolgálati lakás biztosítását 13-13 százalék nevezte meg az otthon maradás feltételeként. A képzési rendszer müködésének megváltoztatását elsősorban a fogorvosok (44\%) tartják elengedhetetlennek. A szolgálati lakás biztosítása egyenlő mértkékben segítené a különböző szakos hallgatók helyben maradását (16-16\%).

A vándorlás tervezett időtartamát tekintve nincs jelentős különbség a különböző távú migrációt tervezők között: hasonló arányban jelölik meg a maradásuk feltételeikként megnevezett tényezőket. Mindössze a szolgálati lakás tekintetében van jelentősebb különbség, amely a rövid- és középtávú migrációt tervezők számára jelentene helyben tartó feltételt.

\footnotetext{
${ }^{185}$ Itt a mediánt alkalmaztam a számtani átlag helyett, mivel ez kevésbé érzékeny a szélsőséges értékekre; a csoporton belüli szórás nagyon nagy. Ennek egy oka lehet, hogy míg egyesek a kezdő fizetést, mások a már szakvizsgázott, tapasztalt szakember bérezését nevezték meg - amint erre már utaltam.
} 


\section{A MOGYE VÉGZŐS ROMÁN ÉS MAGYAR NYELVEN TANULÓ HALLGATÓI KÖZÖTTI MIGRÁCIÓS POTENCIÁL ÖSSZEHASONLÍTÁSA. ${ }^{186}$}

Ez a fejezet az előző részhez hasonló módon vizsgálja a nyers és a tisztított migrációs potenciált, itt viszont a két nyelvi csoport összehasonlítása áll a középpontban. A román nyelvü csoport bevonása az elemzésbe azért fontos, hogy kontrollmintaként használhassuk annak megállapítására, hogy a magyar tannyelvü csoport migrációs potenciálja sajátosnak mondható-e (pl. a kisebbségi helyzetéböl adódóan) vagy inkább az országos mintát követi. Mivel az összehasonlító elemzés nem tartalmazza a nővérek adatait - a román tannyelvű nővéri alminta hiányában -, a vizsgálati csoport eredményei ismét bemutatásra kerülnek a legtöbb változó és összefüggés leírásában.

\subsection{Nyers migrációs potenciál}

A referencia csoportban kissé alacsonyabb a külföldi munkavállalást fontolgatók aránya, mint a vizsgálati csoportban, és kevésbé is tervezik a migrációt.

\section{5. ábra: Külföldi munkavállalás tervezése a vizsgálati és referenciacsoportban}

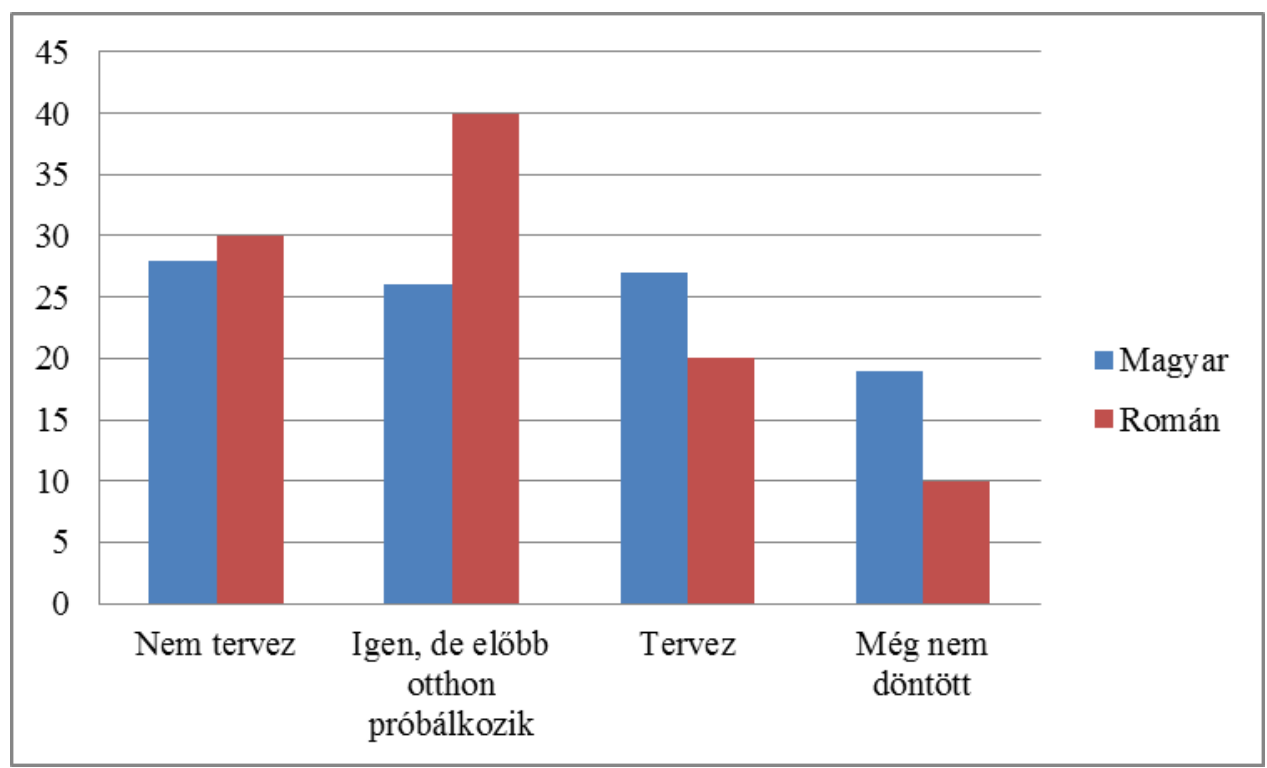

186 Ahogyan a Módszertan fejezet kitért rá, a kontrollmintában a válaszadási arány mindössze 32 százalékos volt (75 fö), ezért az összehasonlítás eredményei erős fenntartásokkal fogadhatóak. Másfelől sajnálatosnak tartottam volna a román nyelvü csoport teljes kizárását az elemzésből, mert jóllehet kevés esetszám van mögötte, mégis a csoportnak közel egyharmadát jelenti. 
A többségi társadalomhoz tartozó hallgatók számára kevésbé jelenik meg a külföldi munkavállalás „kényszerhelyzetként”, inkább bíznak a helyben maradás és „otthon boldogulás” lehetőségében. ${ }^{187}$ A migráció tervezését kétértékű változóvá (tervezi- nem tervezi) alakítva - a határozatlanok kihagyásával - a különbség a két csoport között jóformán eltünik. ${ }^{188}$ A továbbiakban ez a kétértékü változó szerepel az elemzésekben.

\subsubsection{Szociodemográfiai tényezök szerinti összehasonlitás}

A román tannyelvü férfi és női hallgatók ugyanolyan arányban tervezik a külföldi munkavállalást, mint magyar női kollégáik (67\%). A magyar nyelvü csoportban levő férfiak migrációs szándéka kevéssel elmarad ettől (62\%).

A kontrollcsoportban is elsősorban az idősebb korcsoport az, amely inkább tervezi a külföldi munkavállalást.

Családi állapot tekintetében a vizsgálati csoportban leginkább a nem együttélő párkapcsolattal rendelkezők mutatnak hajlandóságot a migrációra (háromnegyedük), és legkevésbé a házasok (egyharmaduk); az együtt élöknek fele szándékszik ( $\chi^{2}=8,284$; szig.: 0,040). Viszont az alacsony esetszám miatt óvatosan kezelelndő ez az összefüggést. A kontrollcsoportban a nőtlenek/hajadonok tervezik leginkább (79\%) a migrációt, a párkapcsolattal rendelkezőknek és együtt élőknek mintegy fele; és legkevésbé a házasok, akárcsak a vizsgálati csoportban.

A hallgatott szak alapján megállapítható, hogy a magyar nyelven tanulók körében négyötöd- kétharmad arányban tervezik a külföldi munkavállalást a különböző szakok hallgatói. ${ }^{189}$ A román nyelvü csoport hallgatói esetében viszont nagy különbségek találhatók: a fogorvosok esetében magas - a magyar fogorvos hallgatókénál magasabb ez az arány (75\%), míg a gyógyszerészeknél jóval alatta marad (42\%, a magyar gyógyszerészek esetében: $60 \%$ ).

A szülők iskolai végzettsége nincs igazán hatással a külföldi munka tervezésére a magyar nyelvü csoport hallgatói esetében, bár leginkább a középszintü iskolai végzettséggel rendelkező szülők gyermekei tervezik a migrációt, míg az alacsony iskolai végzettség kissé a helyben maradási szándékot erősíti. A kontrollcsoport esetében viszont az anya felsőfokú, illetve az apa középfokú iskolai végzettsége növeli a külföldi munkavállalási szándék létrejöttét.

\footnotetext{
${ }^{187}$ Erröl árnyaltabb képet nyerünk az interjúkból.

${ }^{188}$ A vizsgálati csoport esetében $64 \%$, a kontrollcsoport esetében $60 \%$ a migrációt tervezők aránya. Az összevonásra az alacsonyabb esetszám miatt volt szükség.

189 A kontrollminta alacsony elemszámára való tekintettel az elemzés itt és a továbbiakban sem tartalmazza a határozatlanokat.
} 
A szülők foglalkozása nem befolyásolja szignifikánsan a végzősök migrációs szándékait, jóllehet a szülő magasabb beosztással párosuló, magasabb iskolai végzettséget igénylő foglalkozása inkább növeli a külföldi munkavállalás tervezését. A két kivétel: a magyar nyelven tanulók körében a fizikai munkás vagy gazdálkodó anyák, míg a román tannyelvű csoport körében az ugyanilyen foglalkozású/beosztásban dolgozó apák esetében magasabb a migrációs szándék, mint a vezető beosztású vagy diplomás szellemi szülők gyermekei körében; jóllehet nagyon kis eltérésekről van szó. ${ }^{190}$

15. táblázat: A külföldi munkát tervezők aránya a szülők foglalkozása szerint (\%)

\section{Tervez külföldi munkavállalást (\%)}

\begin{tabular}{lcc} 
Apa foglalkozása & $\begin{array}{c}\text { Magyar } \\
\text { tannyelvü }\end{array}$ & $\begin{array}{c}\text { Román } \\
\text { tannyelvü }\end{array}$ \\
\hline Szellemi/ vállalkozó/ szabad szellemi & 77 & 78 \\
Vezető beosztású/ diplomás szellemi & 68 & 58 \\
Gazdálkodó/ munkás & 60 & 69 \\
Inaktív/ elhunyt & 44 & 50 \\
& & \\
& Magyar & Román \\
Anya foglalkozása & tannyelvü & tannyelvú \\
\hline Szellemi/ vállalkozó/ szabad szellemi & 68 & 67 \\
Vezető beosztású/ diplomás szellemi & 65 & 64 \\
Gazdálkodó/ munkás & 73 & 67 \\
Inaktív/ elhunyt & 56 & 71 \\
\hline$N$ & 131 & 60
\end{tabular}

A családi társadalmi státus a vizsgálati csoportban a származás nem függ össze szignifikánsan a külföldi munkavállalási tervekkel, csak megerősíti a szülők iskolai végzettsége és foglalkozása alapján tett megállapításokat. Mégpedig azt, hogy a magasabb státusú családból származók inkább tervezik a migrációt, mint az alacsonyabb státusúak. Viszont a román nyelvű csoportban a migrációt tervezők aránya mind a magasabb, mind az alacsonyabb státusúak esetében kevéssel elmarad a magyar tannyelvü hallgatókétól, ám a vegyes státusú családi háttérből jövő román nyelven tanulók külföldi munkavállalási hajlandósága jóval megelőzi a magyar nyelvü csoport bármely státus-kategóriájába tartozó hallgatóiét (78\%). ${ }^{191}$ Ennek az eltérő tendenciának nem tulajdonítható nagy jelentőség, hiszen nagyon kevés esetszám van mögötte. ${ }^{192}$ Ugyanakkor magyarázatul szolgálhat az is, hogy kedvezőbb anyagi helyzettel

\footnotetext{
${ }^{190}$ Tekintettel az alacsony elemszámra, nem vonhatók le további következtetések.

191 A magyar tannyelvü hallgatók esetében éppen fordított a helyzet: a vegyes státusú családból származók tervezik legkevésbé a külföldi munkavállalást. A részletes adatokat lásd a 8 . mellékletben.

${ }^{192}$ A román végzősök között mindössze 9 fő alkotja a vegyes státusúak csoportját.
} 
rendelkeznek a vegyes státusúak a kontroll-, mint a vizsgálati csoportban. A később készített interjúk nem erősítik meg a társadalmi mobilitás (vegyes státus) és a migrációs tervek együttjárását: a külföldi munkavállalás és a maradási szándék egyaránt jellemző rájuk.

A kontrollmintában a hallgatók kétharmada nyilatkozott úgy, hogy szülei ,jól kijönnek anyagilag"/ gondok nélkül élnek, egyharmadának pedig anyagi nehézségei vannak. A 0tól 10-ig terjedő vagyonossági skálán közel fele (47\%) inkább gazdagnak értékelte szülei anyagi helyzetét, egyharmaduk közepesre (skála 5-6 értéke), míg a fennmaradó hányad inkább szegénynek. A román tannyelvü végzősöket hasonló trend jellemzi, mint a vizsgálati csoport tagjait, de sokkal élesebbek a különbségek. A közepes anyagi helyzetü szülők gyermekei tervezik leginkább a külföldi munkát és a szegényebbek a legkevésbé. A kontrollcsoportban a szegényebb anyagi háttérből jövők jóval alacsonyabb arányban tervezik a migrációt, mint a magyar nyelven tanuló évfolyamtársaik (40\% az 57\%-kal szemben), viszont a közepes anyagi helyzetüek meg sokkal inkább (84\% a 69\%-hoz képest). Az anyagi helyzet 5 fokú skálája már egy homogénebb képet ad, ahol a vizsgálati- és a kontrollcsoport tagjai, illetve a kontrollmintán belül is az ,anyagi nehézségekkel küszködők” és az anyagi „gondok nélkül élők” közel azonos mértékben tervezik a migrációt. A magyar nyelvü csoportban viszont az anyagi gondok megléte inkább erősíti a külföldi munkavállalás tervezését. A két mérőszámból származó adatokat összevetve megállapítható, hogy a „mérsékelt”, azaz kisebb mértékű anyagi nehézségek érzékelése egy közepes szubjektív gazdasági tőkével párosulva - amely lehetővé teheti a szándék kivitelezését - vezet leginkább a külföldi munka tervezéséhez.

Saját lakóingatlannal a román nyelven tanulóknak is, a magyarokéhoz hasonlóan, 12 százaléka rendelkezik; és leginkább a házasságban élők birtokolnak saját lakást/házat. A tulajdonjog megléte vagy hiánya nem befolyásolja számottevően a migrációs terveket, jóllehet a vizsgálati csoportban a saját lakás megléte inkább a helyben maradás tervezését erősíti, a kontrollcsoportban viszont nem mutatkozik ilyen összefüggés. ${ }^{193}$

\subsubsection{Kapcsolati töke szerepe a külföldi munka tervezésében}

A hallgatók közel fele tagja az általa megjelölt célországokba vezető migráns hálózatoknak; a román tannyelvü hallgatók kapcsolati tőkéje csak alig kisebb a magyarokénál (44 százaléka ismer valakit a jelölt országban, míg a magyar nyelvü

${ }^{193}$ A nagyon alacsony elemszám miatt viszont nem vonhatók le messzemenő következtetéseket. 
csoportban ez az arány 52 százalék). ${ }^{194} \mathrm{~A}$ családi/ rokoni kapcsolatok egyforma arányban vannak jelen mindkét csoport esetében, közel egyötödének él rokona az adott országban (23-21\%). A baráti/ismeretségi kapcsolatok kevésbé jellemzőek a kontrollmintára (23\%, magyar nyelvű csoport: 29\%), ám a fő különbség nem ebben rejlik a két hallgatói csoport között, hanem ezeknek a kapcsolatoknak az irányában. Jóllehet óvatosan kell kezelni ezeknek az arányszámoknak az értékelését, hiszen nagyon alacsony esetszám áll mögötte, mégis meglepő a két minta nagyon eltérő migráns hálózata. Míg a vizsgálati csoport esetében a kibocsátó migráns hálózatok dominálnak, addig a kontrollcsoport esetében a befogadó hálózatok, amint az alábbi ábra is szemlélteti.

16. ábra: Barátil ismerősi kapcsolatok a célországokban a vizsgálati és kontrollcsoportban (relatív gyakoriság)

\begin{tabular}{|c|c|c|c|}
\hline \multicolumn{2}{|c|}{$\begin{array}{l}\text { Más nemzetiségủ } \\
\text { —Övével azonos nemzetiségû }\end{array}$} & \multicolumn{2}{|c|}{ Erdélyi $\quad$ Helybéli } \\
\hline 28 & & & 47 \\
\hline 72 & 54 & 74 & 53 \\
\hline Magyar & Román & Magyar & Román \\
\hline
\end{tabular}

Ez arra enged következtetni, hogy a magyar nyelvü csoport migráns baráti kapcsolatai inkább a kibocsátó közösségbe ágyazottak, míg a román nyelven tanulóké inkább korábbi, közvetlen migrációs tapasztalatokra épülnek. Valószínüleg ez a nagyobb mértékü beágyazottság és az ebből fakadó bizalom mint társadalmi tőke az oka annak, hogy a migráns kapcsolatok nagyobb szerepet játszanak a magyar hallgatók külföldi munkavállalási terveiben, mint a román nyelvű csoportban, pontosabban egy-egy ilyen kapcsolat megléte - akár rokoni, akár baráti - inkább vezet a migráció tervezéséhez a magyar tannyelvü hallgatók esetében. A célterületül választott országgal összekötő kapcsolati tőkével nem rendelkező végzősöknek is bő kétharmada tervezi a külföldi munkát mindkét csoportban, ami a migrációs kultúra jelenlétére utal (Kandel \& Massey 2002; Castles 2004).

${ }^{194}$ Ez eltér a korábbi részben bemutatott arányszámtól. Ez a különbség a nővéri alminta kihagyásából adódik. 
A más országokkal összekötő kapcsolatok lényeges szerepet töltenek be információforrásként. A vizsgált népesség 57 százaléka nevezte meg személyes kapcsolatait, mint azt a szálat, amelyen elindulna, ha külföldön állást akar(na) szerezni; a kontroll népességben ez az arány 36 százalék volt. ${ }^{195} \mathrm{~A}$ külföldi munkavállalás érdekében már megtett lépések között is első helyen áll az olyan személyes barátoktól/ismerősöktől való érdeklődés, akiknek már van migrációs tapasztalata; jóllehet a kontroll népességre kevésbé jellemző (16 százalékuk jelölte meg, míg a magyar nyelvü csoport 32 százaléka). Egy másik kérdés azt vizsgálta, hogy van-e más szerepe az információforráson túl a migráns kapcsolatoknak, pontosabban: észlelhetö-e toborzás a kapcsolat másik tagja részéről, mely a migráció tervezését bátorítja.

16. táblázat: Célszemély szerepe a migrációs tervekben

Hívták-e külföldre ott élö rokonai/barátai Magyar Román

\begin{tabular}{lcc}
$(\%)$ & tannyelvü & tannyelvü \\
\hline Nem hívták & 21 & 26 \\
Látogatóba hívták & 33 & 22 \\
Bátorították is ottani munkakeresésre & 45 & 52 \\
\hline$N$ & 75 & 27
\end{tabular}

A román tannyelvü hallgatók is legalább akkora mértékben tapasztalnak bátorítást a külföldi munkavállalásra, mint a magyar nyelven tanulók.

A kapcsolati tőke és a külföldi munka tervezése nem mutat összefüggést a vizsgálati csoport esetében: leginkább azok tervezik a migrációt, akiket nem hívtak külföldön élő rokonaik (90\%), legkevésbé pedig azok, akiket bátorítottak is külföldi munkakeresésre (82\%). A kontrollcsoport esetében: legkevésbé azok tervezik a migrációt, akiket látogatóba hívtak külföldön élö hozzátartozóik/ ismerőseik (ezeknek 67 százaléka tervezi), leginkább pedig a külföldi munkakeresésre bátorítottak tervezik (90\%). Úgy tünik tehát, hogy a kontrollcsoport esetében sokkal inkább befolyásolja a migrációs terveket a kapcsolat másik tagja részéről megnyilvánuló aktív szerep, mint a vizsgálati csoport esetében. ${ }^{196}$ Vagyis megfordítva az állítást: a magyar nyelvű csoport tagjai akkor is tervezik a külföldi munkát, ha nem hívták őket. Ez egy megnyilvánulási formája lehet annak a jelenségnek, amit Gödri ír le a ténylegesen mobilizált és nem mobilizált társadalmi tőke kapcsán (Gödri 2010). A vizsgált népesség inkább információs csatornaként használja/ használná migráns társadalmi tőkéjét, de

\footnotetext{
195 Több válaszlehetőséget is megjelölhető volt. A magyar nyelvű hallgatók körében hasonló arányban jelenik meg az internet mint információs forrás, a románok viszont sokkal inkább támaszkodnak a világhálóra (61\%).

196 A kis elemszám miatt viszont további kutatásra lenne szükség ezen összefüggés érvényességének megállapításához.
} 
mobilizálható segítség- forrásként müködhet, amivel szükség esetén élhetnek - éppen a már korábban említett beágyazottság vagy az abból fakadó közösségi szolidaritás alapján. Másfelől a túlnyomó többségében erdélyi származású, külföldön dolgozó/ élő rokonok/ barátok jelenléte a tölük szerzett információkkal párosulva vezethet a „ha neki sikerült, én is meg tudom csinálni” stratégiához. ${ }^{197}$ És ez a vélekedés eredményezheti ezt a fajta „egyéni” döntést, annak ellenére, hogy nem bátorítják kifejezetten.

\subsubsection{Célországok}

Több potenciális célországot is megnevezhettek a végzősök. Az előző fejezet bemutatta a magyar nyelvü csoport számára legfontosabb célterületeket (Németország, Anglia és Magyarország), amelyek csak részben fedik a kontrollcsoportban kedvelt célországokat.

\section{7. ábra: Emlitett célországok a vizsgálati és kontrollcsoportban (\%)}

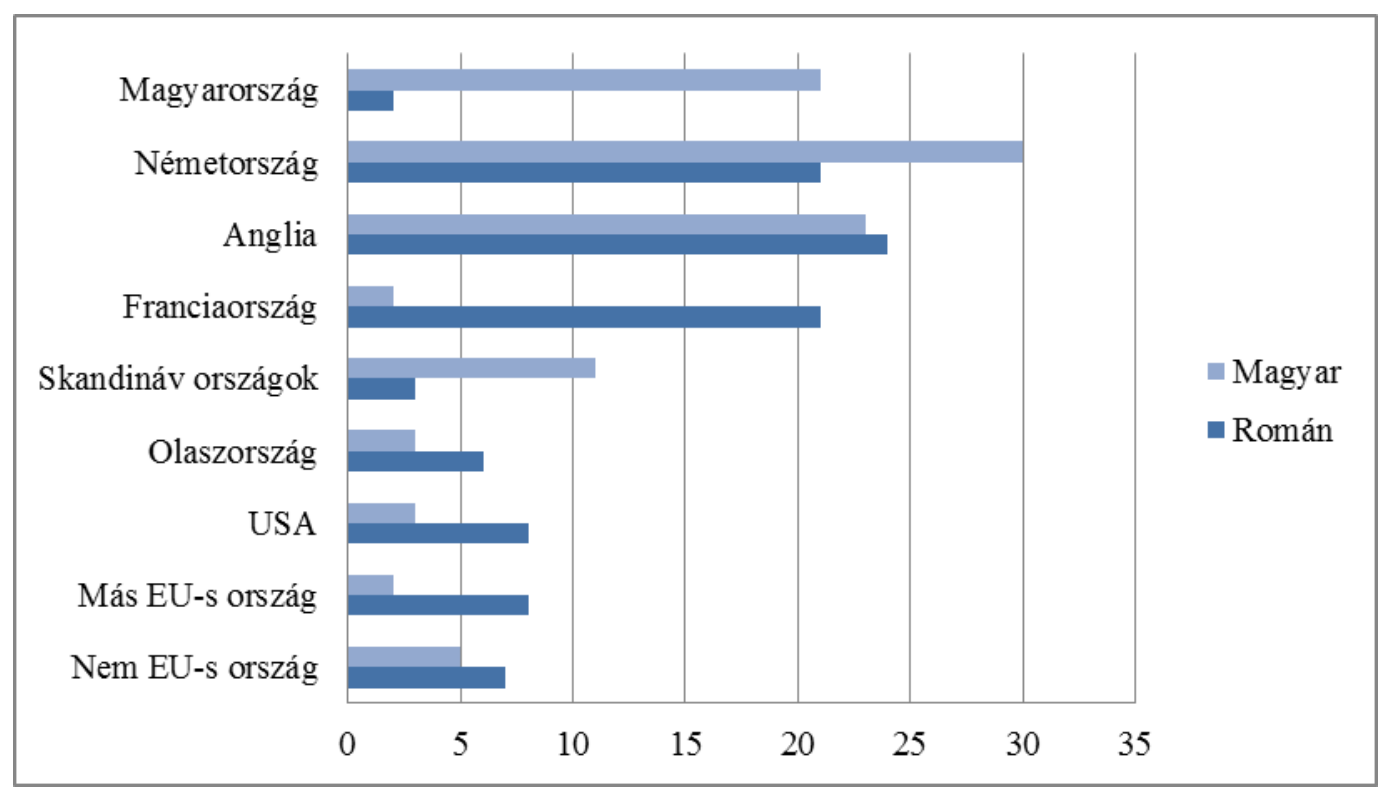

$N=220$

Visszaigazolódni látszik az elméleti felvezetésben említett megállapítás, miszerint a többségi és kisebbségi társadalom migráns hálózatainak bizonyos mértékü összefonódása ment végbe, de nem olvadtak teljesen össze (Gödri \& Kiss 2009; Kiss 2012). Anglia és Németország mindkét csoport számára fontos célterület, viszont a románok a nyelvi- kulturális hasonlóságok, a történelmi kapcsolatok (Portes \& Böröcz 2001) és a már kialakult hálózatok miatt sokkal inkább választják Franciaországot vagy Olaszországot. Érdekes viszont a Skandináv országok és az USA esetében mutatkozó eltérés; az előbbi a magyar, utóbbi a román tannyelvü hallgatókat vonzza inkább. Az USA népszerüsége nem meglepő, már évek óta nagy vonzást gyakorol a román

${ }^{197}$ Ez a fajta attitűd megjelenik később az interjúkban. 
egészségügyi dolgozókra (Rohova 2011). ${ }^{198}$ A Skandináv országok (elsősorban Svédországot jelenti) népszerüségüket valószínűleg aktív munkaerő-toborzásuknak és a kínált magas béreknek köszönhetik - erre utalnak a Magyarországra vándorolt egészségügyi dolgozókkal és a potenciális migránsokkal készült interjúk.

\subsection{Célországok és a hallgatott szak}

A referencia csoportban - a vizsgálati csoporthoz hasonlóan - Németország valamennyi szakos hallgató számára népszerü; Anglia főként a gyógyszerész hallgatókat vonzza (64 százalékuk említette) és legkevésbé a fogorvos hallgatókat (29\%). Franciaországban és Olaszországban főként a majdani gyógyszerészek és fogorvosok vállalnának munkát, míg a Skandináv országokba kizárólag a fogorvosok vágynak (a vizsgálati csoport esetében viszont föként az orvosok). Tengerentúlra inkább a gyógyszerészek és orvosok szándékoznak menni, és más EU-s vagy nem Uniós országokat elsősorban az orvosok említettek (ezek: Svájc, Ausztrália, Ausztria, Spanyolország, Belgium, Törökország, ÚjZéland, Málta, Görögország, Kanada).

\subsection{Célországok és a migráció időzítése}

A migráció tervezett ideje és a megnevezett célországok között esetenként szoros összefüggést találunk. Az alábbi táblázat szemlélteti, hogy mindkét csoportban magas a határozatlanok aránya, amely a migrációs szándékok tényleges kivitelezésének „esélyét” csökkenti. A magyar nyelvü csoportban magasabb a határozatlanok aránya, amit részben „ellensúlyoz” a közvetlenül diplomázás után külföldre menni távozók szintén magasabb aránya.

17. táblázat: A vándorlás tervezett ideje a vizsgálati- és kontrollcsoportban (\%)

\begin{tabular}{lcc} 
& $\begin{array}{c}\text { Magyar } \\
(\%)\end{array}$ & $\begin{array}{c}\text { Román } \\
(\%)\end{array}$ \\
\hline Rögtön diplomázás után & 26 & 18 \\
Rezidensként & 15 & 22 \\
Szakorvosként & 9 & 23 \\
Néhány év tapasztalatszerzés & & \\
után* & 8 & 7 \\
Még nem tudja & 42 & 30 \\
\hline$N$ & 152 & 60
\end{tabular}

\footnotetext{
198 Románia Európai Unióhoz való csatlakozását követően a potenciális migráns román egészségügyi dolgozók körében a kedvelt célországok Franciaország, Olaszország, Spanyolország, Egyesült Királyság, Belgium, Németország, Svájc, USA és Ausztrália voltak (Rohova 2011). Ezen országok sorrendje a Romániából érkező migráns népessége - stock adatok - szerint a következő: Olaszország, Spanyolország, Németország, Magyarország, USA, Anglia és Egyesült Királyság, Skandináv országok, Franciaország (United Nations, Department of Economic and Social Affairs 2013a).
} 
*Csak a gyógyszerész és nővér hallgatók rendelkezésére álló válaszlehetőség. Az orvostan- és fogorvos hallgatók által „rezidensként” és „,szakorvosként” jelölhető kategóriák megfelelője.

Azok a magyar tannyelvü hallgatók, akik közvetlenül diplomázás után terveznek külföldön munkát vállalni, leggyakrabban Németországot, Magyarországot, Angliát és a Skandináv országokat nevezték meg célterületként; a román hallgatók esetében pedig Németország, más Uniós országok, az Amerikai Egyesült Államok és Anglia jelenik meg. A magyar nyelvű csoportban a tervezett időt illetően határozatlanok körében a leggyakrabban említett célországok sorrend szerint Magyarország, Skandináv országok, Anglia, Németország, Olaszország és nem EU-s országok. A román tannyelvü, terveikben még bizonytalan hallgatók esetében Olaszország, Németország, Franciaország és más EU-s országok szerepelnek. Megállapítható, hogy az elsődleges célországok a pályájuk bármely szakaszában levő egészségügyi dolgozók számára vonzó, legyenek friss diplomások, rezidens vagy szakvizsgával rendelkező orvosok, vagy több éves tapasztalattal rendelkező gyógyszerészek.

\subsubsection{Célországok és idegennyelv-ismeret}

A nyelvtudás tekintetében nincs nagy különbség a két hallgatói csoport között, a felsővagy középfokú nyelvvizsga bizonyítvánnyal igazolható tudást véve alapul. A magyar nyelvü csoport 30 százaléka rendelkezik egy vagy két nyelvvizsga bizonyítvánnyal, míg a román tannyelvü végzősök 21 százaléka. Sokkal nagyobb különbség - és egyben ellenkező irányú összefüggés - található a saját megítélésen alapuló nyelvtudás tekintetében. Társalgási szinten beszél és nyelvvizsgával rendelkezik legalább egy nyelven a román nyelvü csoport bő négyötöde, míg a magyar tannyelvü hallgatók esetében az arány kétharmad. ${ }^{199} \mathrm{~A}$ magyar nyelven tanulók körében a nyelvvizsga bizonyítvánnyal rendelkezők átlag felett jelölték Németországot, Angliát, az Egyesült Államokat, Olaszországot és más Uniós tagállamokat. A román nyelvű csoportban a magasabb nyelvtudású végzősök átlag felett Angliát, az Amerikai Egyesült Államokat és más, EU-n kívüli országokat neveztek meg célországként. Az angol nyelvterületek népszerüsége körükben annak is köszönhető, hogy legtöbben az angol nyelvtudásukat tudják hivatalos bizonyítvánnyal is igazolni. ${ }^{200}$ Viszont a tágabb értelemben vett (önbesorolásos) idegennyelv-ismeretre alapozva, a legalább társalgási szintü nyelvismerettel rendelkezők átlag felett választják a magyar tannyelvü hallgatók esetében még a Skandináv országokat (míg a többi, korábban megnevezett ország

\footnotetext{
${ }^{199}$ A román nyelv nem számított az idegen nyelvek közé.

${ }^{200}$ A magyar nyelven tanulók közül a külföldi munkát tervezök egynegyede (25 fö) rendelkezik középvagy felsőfokú nyelvvizsgával angol nyelvböl; a román tannyelvü hallgatók közül 6 fő (16\%).
} 
továbbra is megtartja vonzerejet), a román nyelvü csoportban pedig Németországot, Franciaországot és a Skandináv országokat.

Eltérő az önbesoroláson alapuló „, jó tanuló” vagy „közepes tanuló” kategóriába való tartozás és az idegen nyelvismeret közötti összefüggés a vizsgálati és a kontrollnépességben. A magyar nyelvü csoportban a jó tanulók nagyobb aránya beszél legalább egy idegen nyelvet, viszont nyelvvizsga bizonyítvánnyal való rendelkezés tekintetében nem térnek el a közepes tanulóktól (mindkettő 30\%). A román tannyelvü végzősöknél majdhogynem fordított a helyzet: legalább társalgási szintű nyelvtudással rendelkező jó és a közepes tanulók aránya nem különbözik nagy mértékben $(90 \%$ és $83 \%)^{201}$, viszont csak feleannyian rendelkeznek nyelvvizsga bizonyítvánnyal a közepes (19 százalék a 44 százalékhoz képest), mint a magukat jó tanulónak minősítő hallgatók. ${ }^{202}$ Mivel ennyire különbözőképpen történik a jó tanuló megítélése a két csoportban, továbbra is a nyelvvizsga bizonyítvánnyal való rendelkezés és nyelvismeret mutatói szerepelnek az elemzésekben.

A nyelvismeret mint inkorporált humán tőke hatása kissé eltér a két csoportban. A nagyobb humán tőke serkenti a külföldi munkavállalás tervezését mindkét csoportban, ám a diplomával igazolható nyelvismeret hiánya nem hat gátlóan a migrációs szándékokra a román hallgatók esetében.

18. táblázat: Nyelvtudás és külföldi munkavállalás tervezése közötti kapcsolat

\begin{tabular}{lcc} 
Nyelvtudás szintje & $\begin{array}{c}\text { Tervez külföldi munkavállalást (\%) } \\
\text { Magyar }\end{array}$ & Román \\
\hline Alacsony szintü idegen nyelvtudás & 64 & 60 \\
Társalgási szintü & 71 & 74 \\
& & \\
Nyelvvizsga bizonyitvánnyal & & 71 \\
\hline Nem rendelkezik & 68 & 50 \\
Rendelkezik & 71 & 58
\end{tabular}

Még ha az alacsony elemszám miatt torzítanak is a fenti arányszámok, a trendek különbözősége a két csoportban elég egyértelmű.

Szignifikáns az összefüggés a nyelvismeret és az idegen nyelvű média (szakfolyóirat, nyomtatott és elektronikus sajtó) fogyasztása között a vizsgálati csoportban: ${ }^{203}$ a magasabb szintű nyelvismerettel rendelkezők jóval nagyobb arányban rendszeres

\footnotetext{
${ }^{201}$ Ebben a nyelvvizsga bizonyítvánnyal rendelkezők is benne vannak.

${ }^{202}$ Meglehet, hogy a többségi társadalom tagjai körében a jó tanuló egyik objektív ismérve a nyelvvizsga bizonyítvány birtoklása.

${ }^{203}$ A magyar tannyelvü hallgatók jó kétharmada nyilatkozott úgy, hogy rendszeres fogyasztója valamely vagy több idegen nyelvü médiának; a román nyelvü csoportnak fele.
} 
fogyasztói a külföldi médiának, mint a gyengébb nyelvismerettel bírók, mindkét csoport esetében. Éppen ezért nem meglepő, hogy az idegen nyelvű média-fogyasztás és a külföldi munkavállalás közötti kapcsolat a nyelvtudás és a migrációs szándékok közötti összefüggést tükrözi. Vagyis azok a magyar hallgatók, akik rendszeresen fogyasztanak külföldi médiát inkább tervezik a külföldi munkát, mint a ritkán vagy sosem fogyasztók; a román végzősök körében viszont éppen fordított az összefüggés: az idegen nyelvü média gyakori fogyasztása nem növeli a migráció tervezésének valószínüségét (58 százaléka tervezi, míg a ritkán vagy nem fogyasztók 77 százaléka).

Az idegen nyelvü média fogyasztása és a kapcsolati tőke között nem figyelhető meg összefüggés - a várakozásokkal ellentétben -, mint ahogyan a migráns kapcsolatok és az idegen nyelv ismerete között sem. Ez utóbbi viszont nem áll a kontrollcsoportra, mert esetükben egy, a célországban élő barát szükségszerüen feltételezi a nyelv ismeretét, már amiatt is, hogy ezek többnyire nem román nemzetiségüek.

Érdekes módon a magyar nyelvü csoport esetében tapasztalt összefüggés a származás és nyelvtudás között (alacsonyabb státusúak a legkevésbé, a magas státusúak leginkább beszélnek legalább egy idegen nyelvet), a román hallgatók körében nem érvényes. Az ő esetükben az alacsonyabb státusú családból jövő diákok ugyan kisebb aránya rendelkezik nyelvvizsga bizonyítvánnyal, mint a magasabb státusúak, de legkevésbé a vegyes státusúak. Hasonló összefüggés mutatkozik - jóllehet sokkal kisebb eltérésekkel a különböző kategóriák között - a legalább társalgási szintü idegennyelv ismeret vizsgálatakor (beleértve a nyelvvizsgát is): leginkább a magas státusúak beszélnek folyékonyan legalább egy idegen nyelvet (86\%), és legkevésbé a vegyes státusúak (78\%). Ám ezek a kis különbségek akár a kis méretű minta torzításaiból is adódhatnak.

\subsubsection{Coping potenciál: Attitüdök}

\subsubsection{Helyzet- és jövőkép}

A kontrollcsoport esetében a vizsgálati csoport számára megfogalmazott hat állítás közül csak öt szerepelt; az erdélyi magyarság jövőjét érintő kijelentést nem tartalmazta a román nyelvű kérdőív. Az ország ifjúságának jövőjét, pontosabban annak kilátástalanságát hasonlóképpen értékelik a többségi és kissebbségi társadalom tagjaiból álló jövőbeli egészségügyi dolgozók (román tannyelvű: Mean=2,85, magyar tannyelvű: Mean= 2,81). ${ }^{204}$ Kissé kedvezőbbnek vélik a külföldön élö, orvosi pályát választó nők

${ }^{204}$ Egy 1-től 5-ig terjedő skálán értékelve, ahol az 1: egyáltalán nem ért egyet, az 5: teljesen egyetért. Lásd az előző fejezetben. 
helyzetét a hazainál a román nyelvű csoport hallgatói (Mean=2,75, magyarok: 2,16) ${ }^{205}$ A kezdő fizetést ők is elégtelennek látják a megélhetéshez (Mean= 3,46, magyar tannyelvü: 3,77) - kiugróan magas arányban vélekednek eképpen az orvostan-hallgatók. Leginkább a bérkülönbségek kapcsán értettek egyet: a végzősök értékelése szerint a nyugaton elérhető bérek feléért többségük biztosan a maradás mellett döntene (Mean= 3,59; magyar tannyelvü: 3,67). A hálapénz szükségességéröl is hasonlóképpen vélekedik a két végzős csoport (Mean=3,53; magyar tannyelvü: 3,60). Összességében elmondható tehát, hogy a pesszimista jövőkép nem(csak) a kisebbségi léthelyzetböl adódó sajátosság, hanem a fiatal és/ vagy a gyógyítás pályáját választó társadalomra általánosan jellemző.

A fiatalság jövőjéhez és a pályakezdők bérezéséhez való hasonló attitüdök a két csoportban a külföldi munkavállalási tervekkel való összefüggésükben is hasonlóságot mutatnak: a pesszimizmus inkább vezet a külföldre vándorlás szándékának kialakulásához, vagy a migrációt tervezők inkább hajlamosak a kilátástalan jövőre hivatkozva legitimálni szándékukat. Az általában negatív állításokat helyeslők körében magasabb a migrációt tervezők aránya, mint a kijelentésekkel együtt nem értők körében; és ez a különbség nagyobb a vizsgálati, mint a kontrollmintában. Ez alól az orvostanhallgatóknak a külföldön orvosként dolgozó nők esélyeire vonatkozó és a hálapénzt érintő állításokról való véleménye képez kivételt: az ezekhez való attitüd a magyar nyelven tanulókat nem, csak a román nyelvü csoport tagjait befolyásolja migrációs terveikben, erősítve azokat.

\subsubsection{Méltányosság}

A társadalom müködési elvei közül a magyar nyelvü csoport háromötöde a hozzájárulással arányos részesedést tartja méltányosnak, egyharmada a legjobb képességek szerinti hozzájárulást és szükség szerinti részesedést; és hét százalékuk az egyenlő részesedést véli helyénvalónak. A román tannyelvü hallgatók döntő többsége (89\%) az arányosság elvét, 6 és 5 százalékuk pedig a szükség szerinti részesedést, illetve az egaliteriánus elosztást támogatja. Mindez összefüggésben áll azzal, ahogyan látják jövőbeli orvosként/fogorvosként/gyógyszerészként a társadalmi kiadásokhoz és a közös javakból való részesedésük méltányosságát. A magyar nyelvü csoportnak több mint egyharmada véli úgy, hogy sokkal többel járul majd hozzá a társadalom terheinek

\footnotetext{
205 Érdekessége ennek a véleménynyilvánításnak az, hogy míg a magyar tannyelvű hallgatók körében inkább a nők tartják előnyösebbnek külföldön élő női kollégáik helyzetét a sajátjukhoz képest, addig a kontrollcsoportban a nők a férfiaknál kevésbé értékelték úgy, hogy a női orvosok külföldön elönyösebb helyzetben vannak szakterület választás tekintetében.
} 
viseléséhez, mint amennyit cserében kapni fog, ${ }^{206}$ kevesebb mint egyharmada ugyancsak méltánytalannak véli magával szemben a hozzájárulás-elosztás mérlegét, úgy vélekedve, hogy többel járul hozzá, mint amennyit kap. ${ }^{207}$ Fennmaradó szük egyharmaduk pedig úgy értékeli, hogy ugyanannyit vagy többet fog kapni a társadalomtól, mint amennyivel hozzájárul a közös kiadásokhoz. A román tannyelvü végzősök több mint fele helyezkedik el a skála felső végén, nagyon méltánytalannak ítélve jövőbeli helyzetét, és egyötödük gondolja úgy, hogy ugyanannyit vagy többet kap majd, mint amennyivel hozzájárul a társadalom müködéséhez. Mindkét csoport esetében az orvosok tartják legméltánytalanabbnak jövöbeli helyzetüket (a kontrollcsoportra még inkább jellemző), a gyógyszerészek pedig a leginkább méltányosnak (a kontrollcsoportban kisebb arányban jellemzö).

Külföldi munkavállalási terveik és jövőbeli egészségügyi dolgozókként a helyzetük méltányosnak vagy méltánytalannak való megítélése ugyanolyan összefüggést mutat, mint korábban a teljes magyar tannyelvü mintán is megmutatkozott: leginkább azok tervezik a külföldi munkát, akik inkább méltányosnak látják az elosztást - mindkét csoportban háromnegyede ezeknek a hallgatóknak. A jövőjüket nagyon méltánytalannak érzők kétharmada tervez migrációt, míg legkevésbé a kissé méltánytalannak érzők (magyar nyelvü csoportnak több, mint fele; a román nyelven tanulók jó egyharmada). ${ }^{208}$

\subsubsection{Elégedettség}

Az egyetem által nyújtott szakmai képzéssel a román nyelven tanulók elégedettebbek $(\text { Mean }=3,39)^{209}$, mint a magyar tannyelvűek (Mean=2,93); és ez külön-külön érvényes minden szakra is. A magyar nyelvü csoportban szignifikáns a különbség az eltérő szakok elégedettségét tekintve $(\mathrm{F}=13,953$; szig.: 0,000): legkevésbé a fogorvos hallgatók (Mean= 2,37) és leginkább a gyógyszerész hallgatók elégedettek (Mean= 3,22 ). A kontrollcsoportban is a végzős gyógyszerészek a legelégedettebbek (Mean= 4,01) az intézményben kapott szakmai képzéssel, de a legelégedetlenebbek az orvostanhallgatók (3,22), amely átlag viszont még mindig magasabb a magyar tannyelvü orvostan-hallgatói átlagnál $(3,00)$, vagyis nagyobb mértékü elégedettséget takar. Legnagyobb különbséget a fogorvos végzősök között találunk, a román nyelven tanulók sokkal elégedettebbek (Mean=3,37).

\footnotetext{
${ }^{206}$ A skálán 8 vagy annál nagyobb értéket jelöltek (részletekért lásd az előző fejeztet).

${ }^{207}$ Skálán 6-7-es érték.

${ }^{208}$ Ennek lehetséges magyarázatáról már beszéltem a vizsgálati csoport elemzése kapcsán (lásd a 0. alfejezetet)

${ }^{209}$ Egy 1-5-ig terjedő skálán, ahol az 1 a nagyon elégedetlen, az 5-ös pedig a nagyon elégedettet jelenti.
} 
A szakmai képzéssel való elégedettség és a külföldi munkavállalás tervezése között összefüggés található: minél elégedetlenebb valaki a kapott képzéssel, annál inkább szándékszik külföldön dolgozni. Az elégedetlenség részben az országban meglévő más egyetemeken folyó képzéssel való összehasonlításból ered, másfelől tudatában vannak annak, hogy külföldön más technikai felszerelés, infrastuktúra áll az egészségügyben dolgozók és a hallgatók rendelkezésére, és a migrációtól remélik a felzárkózást, saját tudásuk innovációját. ${ }^{210} \mathrm{Az}$ elégedetlenség mint fontos migrációs motiváció itt is beigazolódik, sőt a kontrollcsoportban még inkább egyértelműen látszik ez, mint a vizsgálati csoportban. A román nyelvü csoport esetében a szakmai képzéssel elégedetlenek nagyobb arányban tervezik migrációt, de másfelöl az elégedettség is inkább erősíti a maradási szándékot, mint a magyar nyelvü csoportban.

19. táblázat: Szakmai képzéssel való elégedettség és a külföldi munka tervezése közötti összefüggés

Tervez külföldi munkavállalást (\%)

Magyar

\begin{tabular}{lcc} 
Szakmai képzéssel való elégedettség & tannyelvü & Román tannyelvü \\
\hline Elégedetlen & 72 & 91 \\
Elégedett is meg nem is & 63 & 82 \\
Elégedett & 62 & 53 \\
\hline$N$ & 137 & 62
\end{tabular}

Eddigi életükkel a magyar nyelvü csoport elégedettebb, mint román tannyelvü évfolyamtársaik $^{211}$ (Mean= 7,42; román: 6,88). ${ }^{212} \mathrm{~A}$ különbség elsősorban a fogorvos hallgatók nagyon eltérő elégedettségi szintjének - a vizsgálati- és a kontrollcsoportban tudható be (magyar: 7,29; román: 6,24); a másik két szakon sokkal kisebb az eltérés. Az élettel való elégedettség gyenge összefüggést mutat a családi származással a magyar nyelvü csoportban: az alacsony státusú családból származók ugyan kevésbé elégedettek (56\%), mint a magas státusúak (66\%), de a legelégedetlenebbek a vegyes státusú családok gyermekei (54\%). A román tannyelvü hallgatók körében a társadalmi státus növekedésével az élettel való elégedettség is nő. A kontrollmintában is található összefüggés igazolja, amit a vizsgálati csoport kapcsán már megállapítást nyert: az

210 Minderre az interjúkból derül fény. Például $\mathrm{H}$ így beszél erről: „Az előnyök... talán a munka minősége, amit végezni fogunk, vagy talán a jól felszereltség élvezete (jó gépek), az itteni helyzethez viszonyítva. És talán meg lenne az esélyünk arra, hogy sokkal jobban fejlödjünk szakmailag, mint itthon. Itthon csak elméleti tanfolyamok vannak és úgy tudom, hogy külföldön nagyobb hangsúlyt fektetnek a gyakorlatra, mintsem az elméletre."

211 Hasonló megállapítás született a Romániában élő magyar fiatalokról általában: míg egyes dimenziókban elégedetlenebbek a román fiataloknál, összességében kedvezőbbnek érzékelik helyzetüket (Kiss et al. 2008).

${ }^{212}$ Egy 0 -tól 10-ig terjedő skálán értékelve az elégedettséget, ahol 0 az elégedetlenség, 10 pedig az elégedettség pólusa. 
elégedettséget leginkább és szignifikáns módon a szülök anyagi helyzete határozza meg - minél magasabbra értékeli egy hallgató szülei helyzetét a gazdagsági skálán, annál inkább elégedett eddigi életével.

Az elégedettség kissé eltérő módon befolyásolja a külföldi munkavállalási szándékot a két csoportban: a kontrollcsoportban a közepesen elégedett(len)ek tervezik leginkább a migrációt, míg mind a nagyfokú elégedettség, mind a nagy mértékü elégedetlenség gátolja az ilyen fajta terveket. Ez nem szorul különösebb magyarázatra, hiszen elég felidéznünk az előző bekezdésben tett megállapítás kapcsán a gazdasági tőke és migrációs szándékok közötti összefüggést. ${ }^{213}$ A vizsgálati csoportban viszont az elégedetlenség általánosságban, mértékétől függetlenül, növeli a migrációs potenciált.

18. ábra: Eddigi élettel való elégedettség hatása a migráció tervezésére (\%)

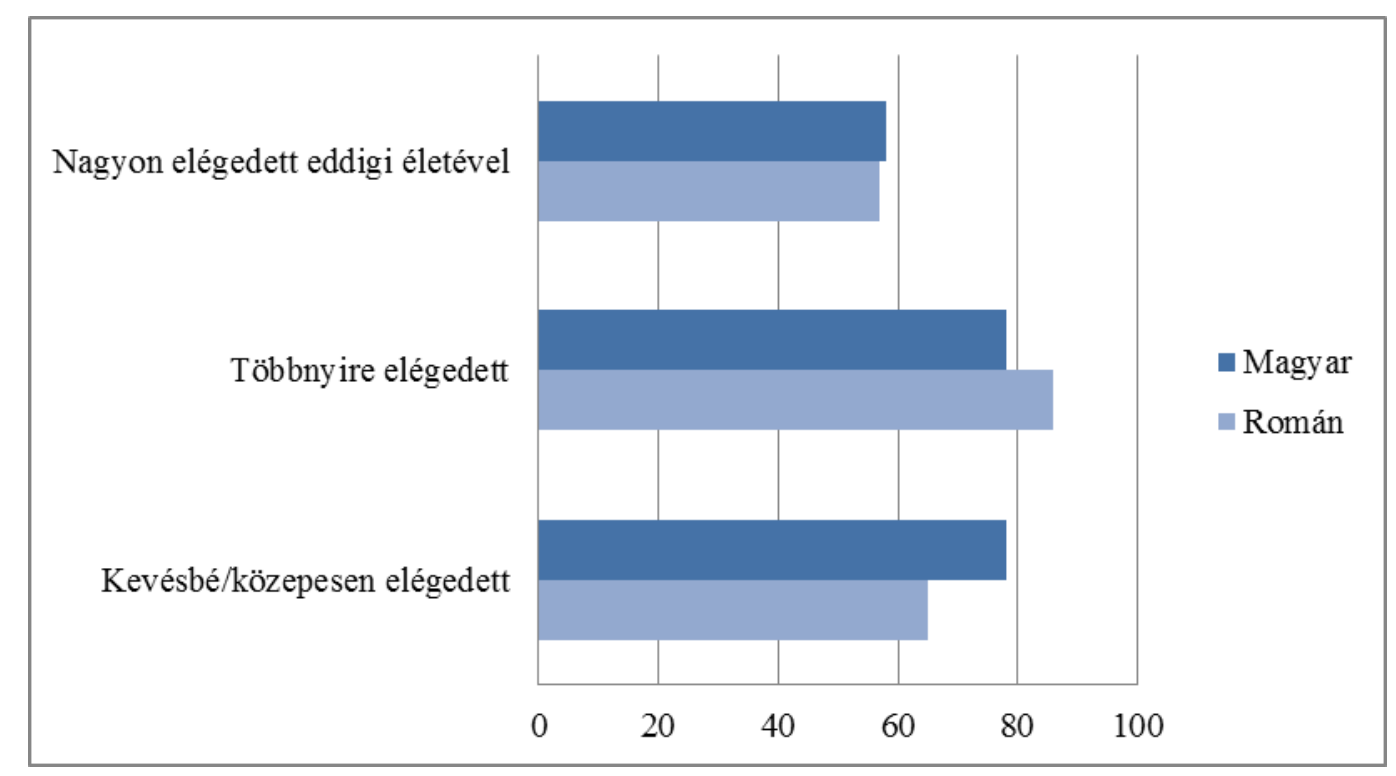

\subsubsection{Motivációk}

A zárt kérdésben felsorolt vándorlási okok rangsora nagyon hasonló a két csoportban, és egyenként megvizsgálva látható, hogy ugyanaz a motiváció kapja a legtöbb említést az adott helyezésen mindkét végzős csoport esetében. Az összesítést tekintve viszont kisebb eltérések mutatkoznak: a magyar tannyelvü hallgatók számára a szakma és anyagi okok megközelítőleg egyforma súllyal szerepelnek, ezek a legfontosabbak, amíg a román hallgatóknál részére az éltszínvonal növelése, illetve a jobb munkakörülmények a legfontosabb motivációk. Viszont a kis számú minta is okozhatja ezeket a - néhány százalékpontnyi - különbségeket.

${ }^{213}$ A kevés elemszámból eredő torzítás lehetősége itt is óvatosságra int. Az összefüggés megerősítéséhez nagyobb mintás kutatásra lenne szükség. 
20. táblázat: Migrációs motivációk rangsora a vizsgálati- és a kontrollcsoportban

Emlités gyakorisága(\%)

\begin{tabular}{|c|c|c|c|c|c|c|c|c|c|c|}
\hline \multirow[t]{2}{*}{ Migrációs motiváció } & \multicolumn{2}{|c|}{ Elsö helyen } & \multicolumn{2}{|c|}{ Második } & \multicolumn{2}{|c|}{ Harmadik } & \multicolumn{2}{|c|}{ Negyedik } & \multicolumn{2}{|c|}{$\begin{array}{l}\text { Összes } \\
\text { emlités }\end{array}$} \\
\hline & Magyar & Román & $M a$ & Ro & $M a$ & Ro & $M a$ & Ro & $M a$ & Ro \\
\hline Magasabb fizetés & 35 & 43 & 23 & 12 & 24 & 11 & 11 & 8 & 88 & 74 \\
\hline Jobb munkakörülmények & 24 & 17 & 38 & 45 & 19 & 16 & 12 & 13 & 91 & 79 \\
\hline $\begin{array}{l}\text { Több szakmai fejlődési } \\
\text { lehetőség }\end{array}$ & 31 & 17 & 23 & 20 & 23 & 23 & 14 & 30 & 86 & 74 \\
\hline Magasabb életszínvonal & 5 & 13 & 8 & 16 & 26 & 41 & 46 & 23 & 79 & 79 \\
\hline Nagyobb szakmai presztízs & 3 & 8 & 5 & 2 & 8 & 7 & 15 & 24 & 30 & 34 \\
\hline $\begin{array}{l}\text { Egyéb (pl. család, román nyelvi } \\
\text { problémák ) }\end{array}$ & & 2 & 3 & 5 & & 2 & 2 & 2 & 5 & 3 \\
\hline
\end{tabular}

A magasabb fizetés mint migrációs motiváció szignifikánsan összefügg a hallgatott szakkal: a fogorvosok és a gyógyszerészek esetében különösen fontos szerepet játszanak az országok közötti bérkülönbségek, mind a vizsgálati, mind a kontrollcsoportban. A jobb munkakörülmények a magyar nyelvü csoportban elsősorban az orvostan- és fogorvos hallgatók számára jelent motivációt, a román tannyelvü hallgatók esetében föként a gyógyszerész és orvostan-hallgatók számára. Több szakmai fejlődési lehetőséget leginkább a magyar tannyelvű fogorvos és a román gyógyszerész hallgatók remélnek a külföldi munkavállalástól. A más országok által nyújtott magasabb életszínvonal főként a gyógyszerész hallgatókat vonzza mindkét csoportban, míg a nagyobb szakmai presztízs a magyar gyógyszerész és a román nyelvü orvostanhallgatókat.

A szülők szubjektív anyagi helyzetét tekintve a rosszabb jövedelmi helyzettel rendelkező hallgatókat minden felsorolt tényező inkább motiválja - leszámítva a nagyobb szakmai presztízst -, mint a ,gazdagokat”. Származás szerint nagyon eltérő mintázat látható a vizsgálati- és a kontrollcsoportban. A magasabb fizetést leggyakrabban a magas és vegyes státusú családból származó magyar tannyelvü hallgatók említik az első négy helyen, a román nyelvü csoportban inkább a vegyes és alacsony státusúak. ${ }^{214} \mathrm{Ez}$ arra utalhat, hogy a magyar tannyelvű hallgatók esetében a jóléti migrációt a lecsúszástól, a relatív deprivációtól való félelem mozgatja, míg a románok nyelvü csoportban a felfele mobilitás eszközeként müködik inkább. A külföldön elérhető jobb munkakörülmények és szakmai fejlődési lehetőségek leginkább a magyar tannyelvű magasabb társadalmi státusú hallgatók számára jelent pull tényezőt, míg a román nyelvü csoport magasabb, illetve vegyes társadalmi státusú családból

${ }^{214} \mathrm{Az}$ interjúk fürtelemzése is megerősíti ezt az összefüggést. 
jövők számára a legkevésbé. A magasabb életszínvonal mint migrációs ok fontossága nem különbözik jelentősen az eltérő származásúak között a vizsgálati csoportban, míg az alacsony státusú román tannyelvü hallgatók számára jelentős vonzerővel bír. A nagyobb szakmai presztízs viszont mindkét hallgatói csoport esetében leginkább a vegyes státusú családból származók részére motiváló.

\subsection{6. Újabb összkép: a logisztikus regresszióelemzés modelljei ${ }^{215}$}

Többváltozós elemzéssel is megvizsgálva a különböző tényezők hatását - és elsősorban a nyelv hatását is bevonva -, a vizsgálati csoportéhoz hasonló eredmények születnek. Ez azt jelenti, hogy a két csoport csak kis mértékben különbözik egymástól (a nyelv, és egyben a nemzetiség hatása csakugyan nem szignifikáns), és a két logisztikus regresszióelemzés eredményei közötti különbségek inkább a nővéri alminta kihagyásának tulajdonítható.

21. táblázat: A külföldi munkavállalási terveket befolyásoló tényezök hatása a nemzetiség (nyelv)kontroll alatt tartásával

A külföldi munkavállalás tervezésének esélye a magyar nyelvü orvos, fogorvos és gyógyszerész hallgatók esetében: Exp (B)

\begin{tabular}{|c|c|c|}
\hline Magyarázó változók & 1. modell & $\begin{array}{c}\text { 2. modell } \\
* * *\end{array}$ \\
\hline \multicolumn{3}{|c|}{ Hallgatói csoport (ref.: román nyelvü) } \\
\hline Magyar tannyelvü & 0,899 & 0,911 \\
\hline \multicolumn{3}{|l|}{ Társadalmi státus } \\
\hline Alacsony & 1,055 & 1,034 \\
\hline Vegyes (ref.) & & \\
\hline Magas & 1,483 & 1,187 \\
\hline \multicolumn{3}{|c|}{ Szubjektív anyagi helyzet } \\
\hline Szegény & $0,414 *$ & $0,186 * *$ \\
\hline Közepes (ref.) & & \\
\hline Gazdag & 0,584 & 0,769 \\
\hline \multicolumn{3}{|l|}{ Kapcsolati tőke } \\
\hline \multicolumn{3}{|c|}{ Nincs/ Családtag/rokon (ref.) } \\
\hline Barát/ismerős & & $3,985 *$ \\
\hline \multicolumn{3}{|l|}{ Nincs fiatalként jövője } \\
\hline Nem ért egyet/Egye & & \\
\hline Egyetért & & $2,859 *$ \\
\hline \multicolumn{3}{|c|}{ Kezdőként képtelen eltartani családját } \\
\hline Nem/Részben ért ę & & \\
\hline Egyetért & & $2,725 *$ \\
\hline$N$ & 194 & 165 \\
\hline Cox \& Snell $\mathrm{R}^{2}$ & 0,03 & 0,15 \\
\hline Nagelkerke $\mathrm{R}^{2}$ & 0,04 & 0,22 \\
\hline
\end{tabular}

Szignifikanciaszintek: $* * *<0,001 ; * * \leq 0,01 ; *<0,1$

${ }^{215}$ Jelen elemzés esetében még nagyobb problémát okoz az alacsony esetszám. 
A szociodemográfiai tényezőket tartalmazó első modell tanúsága szerint az anyagi helyzet befolyása bizonyul szignifikánsnak, eltérően a korábbi modelltől, amelyben az anyanyelv hatása nem volt kontrollálva. A szubjektív szegénység csökkenti a külföldi munkavállalás tervezésének esélyét. A társadalmi státusnak nincs szignifikáns hatása; jóllehet a magyar nyelvű csoportban csak az első modellben volt szignifikáns: a magas státus növelte a külföldi munkavállalás tervezésének esélyét. Ez valószínűleg a nagyobb mértékű homogenitásnak (csak általános- és fogorvosi, meg gyógyszerész hallgatók) és kevésbé a nyelvi hatás kontrollálásának tulajdonítható. ${ }^{216}$

A kapcsolati töke és pszichikai tényezők hatását is tartalmazó második modell alapján megállapítható, hogy továbbra is a migráns hálózatok a legfontosabb befolyásoló tényezők: a baráti migráns kapcsolatok majdnem négyszeresére növelik a migráció tervezésének esélyét, de a jövővel kapcsolatos attitűdök is hasonló módon hatnak. Ezen változók bevonásával a szegénység még inkább csökkenti a külföldi munka tervezésének esélyét.

Összességében elmondható, hogy a nyelv hatásának kontrollálásával, illetve a nővéri alminta kihagyásával, elsősorban a migráns baráti kapcsolat, de a kilátástalannak ítélt jövő és a kezdő fizetés elégtelenségétől való félelem is növeli a külföldi munkavállalás tervezésének esélyét; a szubjektív anyagi szegénység pedig csökkenti azt. A korábbi elemzésekben tapasztalt társadalmi státus hatása megszünik, ami elsősorban az alacsonyabb származású nővérek kihagyásának tulajdonítható.

\subsection{Tisztított migrációs potenciál}

Csupán gondolkodott a migráción a magyar tannyelvü, külföldi munkavállalást tervező hallgatóknak egyharmada, a román nyelvü csoportnak majdnem fele (45 százaléka). A vizsgálati csoport hallgatóinak ötöde két vagy annál is több dolgot tett külföldi munkavállalása kivitelezése érdekében, a kontrollcsoportnak csak 8 százaléka. Időzítés tekintetében legnagyobb arányban azok léptek már, akik legkorábbra - közvetlenül diplomázás utánra - tervezik a migrációt (magyar nyelvü csoport: 90\%, román nyelvü: $82 \%$ ). A néhány éven belül útnak indulók körében a referencia csoportban kétötöd, a vizsgálati csoportban egyharmad tett már valamit, míg az időztés tekintetében határozatlanok egyötöde (román nyelvü), illetve egyharmada (magyar nyelvü). A különböző lépések közül az alábbiakat nevezték meg a hallgatók:

\footnotetext{
216 A nővéri alminta kihagyásával lefuttatott logisztikus regresszióelemzés eredményei szerint a magyar tannyelvü hallgatók esetében az anyagi helyzet hatása nem szignifikáns, viszont a román nyelvü csoport esetében igen. Ebben viszont szerepet játszhatnak a korábban is említett alacsony esetszámok, különösen a kontrollmintában.
} 
22. táblázat: A külföldi munkavállalás érdekében megtett lépések relatív megoszlása a vizsgálati és kontrollcsoportban (\%)

\begin{tabular}{lcc} 
Tett lépés $(e k)$ & $\begin{array}{c}\text { Magyar } \\
\text { tannyelvü }\end{array}$ & $\begin{array}{c}\text { Román } \\
\text { tannyelvü }\end{array}$ \\
\hline Érdeklődés személyes kapcsolat révén & 47 & 35 \\
Információszerzés internetröl & 23 & 35 \\
Konkrét álláshirdetések keresése & 18 & 17 \\
Nyelvtanulás & 3 & 0 \\
Jelentkezett állásra/ interjúra megy & 1 & 10 \\
Egyéb & 8 & 3 \\
\hline$N($ Említések száma) & 104 & 69
\end{tabular}

Megj.: Több válaszlehetöség is jelölhetö volt

Mint már korábban is esett szó róla, a vizsgálati csoport számára a migráns kapcsolatok egyben fontos információs csatornákként is müködnek, mivel részben baráti egyszersmind valószínüleg kollegiális - viszonyt jelölnek; másfelől a kibocsátó közösségbe való erős beágyazottságuknak köszönhetően. Fontosságát jelzi a más információforrások között elfoglalt helye is, amit az alábbi táblázat szemléltet.

23. táblázat: Az igénybe vett vagy potenciális információforrások relativ megoszlása a viszgálati-és a referenciacsoportban (\%)

\begin{tabular}{lcc} 
Információforrások & $\begin{array}{c}\text { Magyar } \\
\text { tannyelvü }\end{array}$ & $\begin{array}{c}\text { Román } \\
\text { tannyelvü }\end{array}$ \\
\hline Személyes kapcsolatok & 32 & 27 \\
Internet & 33 & 47 \\
Munkaerő-közvetítő ügynökség & 23 & 14 \\
Levelezölista (elektronikus körlevél) & 12 & 11 \\
Egyéb & & 2 \\
\hline$N$ (Említések száma) & 176 & 64
\end{tabular}

Megj: Többválaszos kérdés

A magyar nyelvű csoportban nagyobb arányban vennék igénybe a munkaerő-közvetítő ügynökségek szolgálatait, ami arra enged következtetni, hogy inkább hajlandóak az ezzel járó anyagi terheket vállalni a számukra megfelelő külföldi állás megtalálására. ${ }^{217}$

A vizsgálati csoportban a különböző okokból migrációt tervezők körében hasonló a tisztított migrációs potenciál nagysága: leginkább a külföldön elérhető nagyobb szakmai presztízsért vándorlók (53\%) és legkevésbé a magasabb fizetés reményében indulók (47\%) tettek már szándékuk megvalósításáért. A referenciacsoportban összességében alacsonyabb tisztított migrációs potenciál és

${ }^{217}$ Itt is felmerülhet a torzítás problémája. 
motivációk szerint nagyobb szórás található, a lista élén és végén az előbbi két motivációval, csak éppen fordított sorrendben: a jobb munkakörülmények reményében külföldi munkát vállalók 40 százaléka, a magasabb fizetésért migrálók 36 százaléka, illetve a nagyobb szakmai presztízsért vándorlók 29 százaléka lépett már.

A logisztikus regresszióelemzés eredményeit az alábbi táblázat tartalmazza.

24. táblázat: A külföldi munkavállalási tervek megvalósulásának esélyei a nemzetiség (nyelv) változó bevonásával

A külföldi munkavállalási tervek megvalósulásának esélye a nyelv változó bevonásával: $\operatorname{Exp}(B)$

\begin{tabular}{|c|c|c|c|}
\hline Magyarázó változók & 1. modell & $\begin{array}{l}2 . \\
\text { modell } \\
*\end{array}$ & $\begin{array}{l}\text { 3. modell } \\
* * *\end{array}$ \\
\hline $\begin{array}{l}\text { Hallgatói csoport (ref.: román nyelvü) } \\
\text { Magyar tannyelvü }\end{array}$ & 1,648 & 1,715 & 1,177 \\
\hline $\begin{array}{l}\text { Társadalmi státus } \\
\text { Alacsony } \\
\text { Vegyes (ref.) } \\
\text { Magas }\end{array}$ & 1,026 & 0,987 & 1,252 \\
\hline $\begin{array}{l}\text { Szubjektív anyagi helyzet } \\
\text { Szegény } \\
\text { Közepes (ref.) } \\
\text { Gazdag }\end{array}$ & 0,938 & 1,309 & 1,704 \\
\hline $\begin{array}{l}\text { Kapcsolati tőke } \\
\text { Nincs/ Családtag/rokon (ref.) } \\
\text { Barát/ismerős }\end{array}$ & & $2,757 * *$ & 2,709* \\
\hline $\begin{array}{l}\text { Nincs fiatalként jövője } \\
\text { Nem ért egyet/Egyetért meg nem is } \\
\text { (ref.) } \\
\text { Egyetért }\end{array}$ & & $1,858 *$ & 1,345 \\
\hline $\begin{array}{l}\text { Kezdőként képtelen eltartani családját } \\
\text { Nem/Részben ért egyet (ref.) } \\
\text { Egyetért }\end{array}$ & & 1,538 & 1,413 \\
\hline $\begin{array}{l}\text { Motiváció } \\
\text { Szakmai tanulás/fejlődés }\end{array}$ & & & 2,251 \\
\hline $\begin{array}{l}\text { Időzítés } \\
\text { Még nem tudja/ Néhány év múlva (ref.) } \\
\text { Diplomázás után }\end{array}$ & & & $22,272 * * *$ \\
\hline$N$ & 206 & 199 & 198 \\
\hline $\begin{array}{l}\text { Cox \& Snell R } \\
\text { Nagelkerke } \mathrm{R}^{2}\end{array}$ & $\begin{array}{l}0,02 \\
0,03\end{array}$ & $\begin{array}{l}0,09 \\
0,12\end{array}$ & $\begin{array}{l}0,3 \\
0,4\end{array}$ \\
\hline
\end{tabular}

Szignifikanciaszintek: $* * *<0,001 ; * * \leq 0,01 ; *<0,1$

A szociodemográfiai modell (1.) nem szignifikáns, mivel egyetlen általa tartalmazott változó hatása sem az; bár úgy tünik, hogy a magyar tannyelvü hallgatók esetében a 
külföldi munkavállalási szándék nagyobb eséllyel valósulhat meg, ez az összefüggés véletlenszerü lehet.

A migráns hálózat itt is a legfontosabb tényező (2. modell): a migráns baráti kapcsolatok több mint kétszeresére növelik a külföldi munkavállalási tervek megvalósításának esélyét. Változást jelent a teljes magyar nyelvü hallgatói minta tisztított migrációs logisztikus regressziós modelljéhez képest, hogy az attitűd változók közül az általános pesszimista jövőkép hatása bizonyul szignifikánsnak: közel kétszer akkora eséllyel tettek már valamit tervük kivitelezése érdekében azon hallgatók, akik szülőföldjükön kilátástalannak ítélik meg jövőjüket.

A migráció időzítését és a szakmai motiváltságot is tartalmazó 3. modellben a legfontosabb tényező a migráció tervezett ideje: a közvetlenül diplomázás után külföldre távozni készülők huszonkétszer nagyobb eséllyel tettek már a szándékuk megvalósítása érdekében, mint az időzítés szempontjából bizonytalankodók. Ugyancsak növeli a tisztított migrációs potenciált a migráns baráti kapcsolatokkal való rendelkezés. Változást jelent viszont - a nyers migrációs potenciált meghatározó tényezők logisztikus regresszióelemzés eredményeihez képest -, hogy sem a pályakezdőként kapott fizetés szükösségétől való félelem, sem pedig a szakmai motiváltság nem hat szignifikáns módon a külföldi munkavállalási szándék kivitelezésének esélyére. A szociodemográfiai tényezők ebben a modellben sem bizonyulnak szignifikáns hatásúaknak.

Mindezek alapján megállapítható, hogy a tisztított migrációs potenciált legerősebben a vándorlás megvalósításának időbeli közelsége, illetve a célországgal összekötő migráns baráti kapcsolatokkal való rendelkezés, továbbá a kilátástalannak ítélt jövőkép növeli.

Azon kijelentés fényében, hogy a migrációs tervek megvalósításának esélyét a potenciális migráns számára elérhető konvertálható tőkék befolyásolják (Gödri \& Kiss 2009), elmondható, hogy az egészségügy munkaerő-piacára hamarosan belépő erdélyi végzős hallgatók esetében a migráns kapcsolati tőke a kulcstényező, de fontos szerep jut a kulturális és gazdasági tőkének, illetve attitüdöknek is (a jövővel kapcsolatos félelmeknek). Tehát a baráti-kollegiális migráns hálózatokban való tagság, amely ha vagyonossággal, illetve pesszimista jövőképpel társul, nagy eséllyel növeli a tervezett migráció megvalósításának esélyét.

\subsection{Visszatartó tényezők}

A család visszatartó ereje a nők körében erősebb; különösen érzékelhető ez a román hallgatók körében, ahol csakis nők nevezték meg a családot mint olyan tényezőt, ami 
gátolja vagy nehezíti számukra a külföldi munkavállalás tervezését. A szülőföldhöz való ragaszkodás $^{218}$ és a saját nép iránti felelősségtudat inkább jellemző a férfiakra és a magyar nyelvü csoportra. Az otthon - szerettei közelében - való boldogulás reményét tekintve nemek szerint nincs eltérés, viszont a vizsgálati csoportnál inkább jelent helyben tartó tényezőt (kétötöd), mint a referencia csoport tagjai számára (egynegyede említi). Az „otthon is érvényesülő” szaktudásba vetett hit leginkább a magyar tannyelvü csoportban a férfiak, a román nyelvű csoportban pedig a nők számára jelent visszatartó erőt (29 és 28 százalékuk nevezte meg). Továbbra is érvényes a magas társadalmi státusúakra, hogy a szülőföldhöz való ragaszkodás és a saját nép iránti felelősség inkább számukra - kivétel: e tényező a kontrollcsoportban a vegyes státusúak esetében - jelent migrációt gátló tényezőt. A szülőföldjén szakmai „boldogulásba” vetett hit (szerettei közelségének feladása nélkül) leginkább az alacsony és legkevésbé a magas státusúakat tartja vissza a külföldi munkavállalástól a vizsgálati csoportban, míg a kontrollcsoportban éppen fordítva.

\subsubsection{A maradás feltételei}

A magasabb bérek a legerősebb otthon maradásra bíró tényezők (közel háromötöde jelölte meg mindkét csoportnak). Átlagosan 2500 RON-t neveztek meg a magyar nyelvü hallgatók megfelelő fizetésként, a román tannyelvü végzősök 3000 RON-t. A szakok szerint megnevezett bérek nagysága a vizsgálati csoportban már ismertetésre került az előző fejezetben; a román nyelvü csoportban az orvostan-hallgatók átlagosan 2500 RON (kb. $580 €$ ), a fogorvosok 7000 RON (kb. $1830 €$ ), a gyógyszerészek 3250 RON (kb. $760 €$ ) fizetést neveztek meg mint amiért hajlandóak lennének maradni. Az orvosi átlagbérek tekintetében konszenzus van a két csoport orvostan-hallgatói között, a gyógyszerészek bérei is nagyon közel állnak, viszont a román tannyelvü fogorvosok a magyaroknál több, mint kétszer nagyobb fizetést neveztek meg, mint ami otthon tartaná őket. Amint az alábbi ábrán látható, a pályakezdők nagyobb mértékű megbecsülése, a jobb munkakörülmények és felszerelés biztosítása, illetve az idősebb kollégák támogató attitüdje inkább a magyar nyelvü csoport részéröl feltétele a maradásnak, míg a magasabb fizetés a román hallgatók részéről. Fontos visszatartó tényezőnek bizonyul még mindkét csoportban a szakmai színvonal javítása (egyharmaduk nevezte meg).

218 Számomra kissé talányos, hogy ezt egyetlen román tannyelvü hallgató sem jelölte. De mivel a saját nép szolgálatát is csak négyen jelölték, úgy vélem, hogy nem a fordításból adódó torzítás játszik benne szerepet, hanem a „mi” közösség sorvadása, akárcsak a vizsgálati csoport esetében (Sik \& Örkény 2003). 
19. ábra: A maradás feltételeiként említett tényezök relatív gyakoriságai a vizsgálati és a kontrollcsoportban

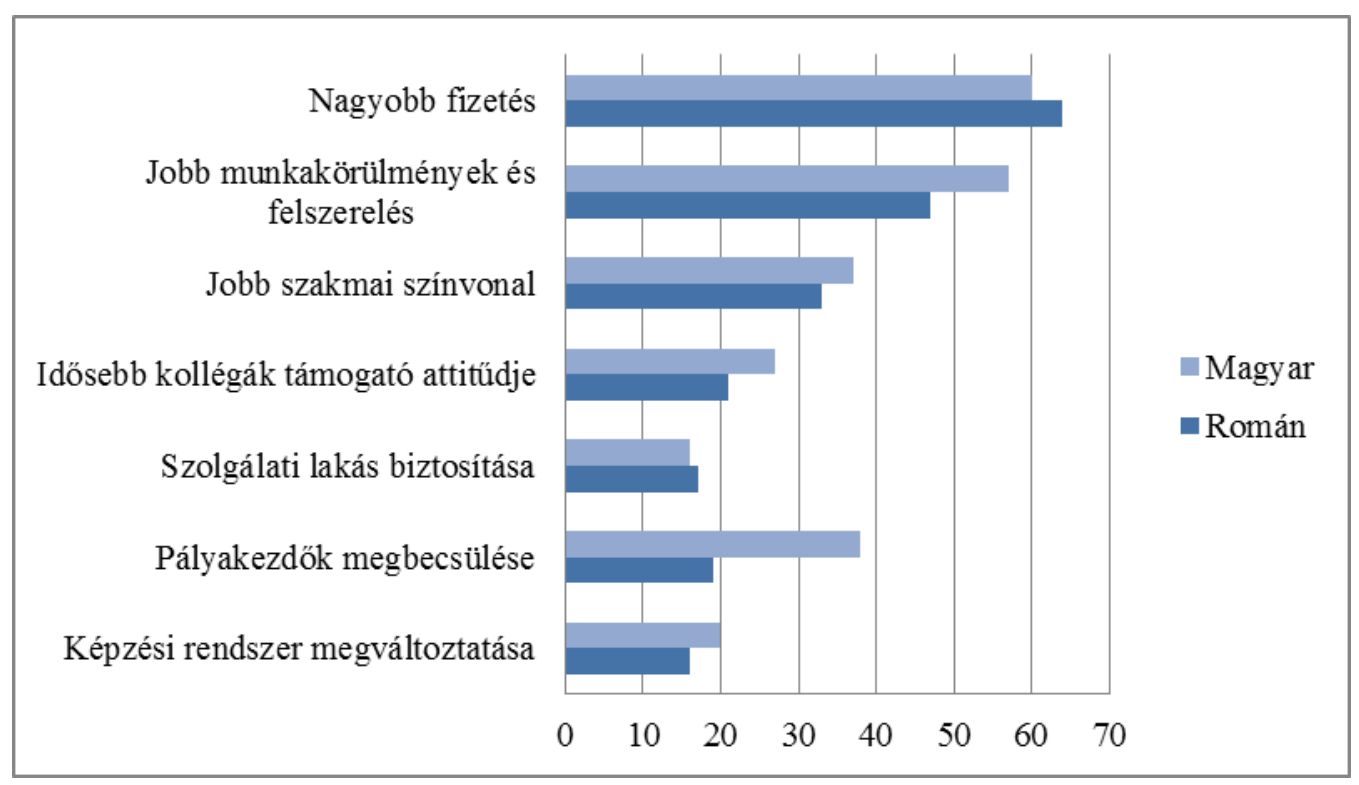

\section{4. Összegzés}

Megállapítható, hogy az egészségügyi pályát választó végzős magyar tannyelvü hallgatók migrációs potenciálja az erdélyi magyar felnőtt népességéhez képest magasnak mondható, mindössze egynegyede nem tervezi; viszont ez egyfelöl a korral, másfelől a szakmaválasztással magyarázható. Közülük is a legfiatalabbak, azaz a nővérek tervezik leginkább a külföldi munkavállalalást; őket az orvostan-hallgatók követik. A kontrollcsoportként vizsgált román tannyelvü hallgatók migrációs potenciálja kevéssel marad el a magyar nyelvü csoportétól; a különbség inkább a vándorlás időzítésében van: a többségi társadalomhoz tartozó diákok nagyobb arányban „próbálkoznának előbb otthon” és kevésbé gondolnak „,kényszerhelyzetként” a külföldi munkavállalásra. ${ }^{219}$ A referencia csoportban az „előbb otthon próbálkozók” és az otthon maradni szándékozók között is több a fiatal, illetve a migrációt biztosan tervezők körében az idősebb.

A többi szociodemográfiai tényezőt vizsgálva tapasztalható, hogy várakozásaimnak megfelelően - nemek szerint nincs eltérés a migráció tervezésében: jóllehet a férfiak kissé nagyobb arányban szándékoznak otthon maradni, a nők körében több a határozatlan. A házas és együtt élő családi állapot, illetve a szülők magasabb kulturális tőkéje szintén a helyben maradási szándékot növeli; a közepes végzettség az „előbb otthon próbálkozást”, míg az alacsony humán tőkével rendelkezés a külföldi

${ }^{219}$ Erre hatást gyakorolhat az eltérő tér-képzet: az erdélyi magyarok számára Románia Kárpátokon túli részei kevésbé jönnek számításba célterületként, mint a nyugati országok (Gödri \& Kiss 2009). 
munkavállalás tervezését erősíti. A kontrollcsoportban fordított a helyzet: mind az apa, mind az anya esetében a felsőfokú végzettség növeli a migrációs potenciált. A szülök foglalkozása eltérő módon hat a migráció tervezésére: a vizsgálati csoportban, leginkább a vállalkozó/ önálló/ szellemi szabadfoglalkozású apák, illetve a szakmunkás/segéd- és betanított munkás/gazdálkodó anyák gyermekei szeretnének külföldön munkát vállalni. A referencia csoportban viszont mind az apa, mind az anya esetében a vállalkozó/önálló/szabad szellemi serkenti leginkább a külföldi munkavállalás tervezését. A szülők iskolai végzettsége és foglalkozása alapján felállított társadalmi státus mutatója szerint az alacsonyabb, azaz felfelé mobil, meg a magasabb társadalmi státusú családból származó magyar tannyelvü hallgatók, akik közepes vagy annál jobb szubjektív anyagi helyzettel rendelkeznek, nagyobb eséllyel terveznek migrációt, mint a vegyes státusú, illetve az átlagosnál rosszabb anyagi helyzettel bírók; bár a vagyonosság másfelől a helyben maradási szándékot is erősítheti (alacsony a határozatlanok és magas az előbb otthoni munkahely kereséssel próbálkozók aránya). Viszont a kontrollcsoportban a vegyes státus növeli leginkább a migrációs potenciált; ám az alacsony esetszám miatt nem tulajdonítható ennek az összefüggésnek nagy jelentőség, hiszen az interjúk alapján készült fürtelemzés sem támasztja ezt alá.

A migráció tervezett idejét befolyásolja a hallgatott szak: legtöbben néhány évet (1-3 év) töltenének külföldön, az orvostan-hallgatókat kivévé; ők a hosszabb távú (4-10 év) kint tartózkodást tervezik. Erre magyarázatul a migráció időzítése és célja szolgál: az orvostan-hallgatók esetében a külföldi munkavállalás gyakran összekapcsolódik a továbbtanulással/ szakosodással, tehát a külföldi szakvizsga megszerzésével, ami több évet vesz igénybe. Leginkább a gyógyszerész hallgatók terveznek végleges elvándorlást (több mint egynegyedük), legkevésbé a nővérek. A magyar nyelvű csoport egynegyede közvetlenül a diplomázást követő időszakban szeretne külföldön munkát vállalni; az időbeli közelség pedig - jelen esetben többszörösen - megnöveli a tervek megvalósításának ,esélyét” (Horváth 2003b).

A migráns hálózatok szerepének fontossága - amint azt a narratív interjúk is előrevetítették - a migrációs potenciál esetében is beigazolódott. A magyar tannyelvü hallgatók körében a migráns kapcsolatok hiányában kissé - de nem szignifikánsan megnövekszik a helyben próbálkozók és a maradni szándékozók aránya. A gyenge kötések megnövelik a külföldi munkavállalás tervezésésének és megvalósulásának esélyét: leginkább a külföldön dolgozó/ élő barátoké. Ez egyfelől azt a korábbi megállapítást támasztja alá, hogy a baráti kapcsolatok a rokoninál fontosabb szerepet töltenek be a fiatalok esetében (Gödri 2010); másfelől megerösíteni látszik azt a feltételezést, hogy a gyenge kötésű migráns hálózatok magasabb státusú migránsokat 
vonzanak, mint az erős kötésü migráns hálózatok (Bagchi 2001). Ezek a baráti és többségében - az interjúk tanúsága szerint - kollegiális kapcsolatok a kibocsátó közösségbe ágyazottak, hiszen többségükben Erdélyből elvándorolt, magyar anyanyelvü egyéneket foglalnak magukba. A baráti-kollegiális hálózatok elsősorban az információ áramoltatást és gyüjtést szolgálják - főként a magyar nyelvű csoport tagjai számára -; így közvetve becsatornázzák adott országok, vagy városok, intézmények irányába a majdani külföldi egészségügyi munkavállalókat, akik a különböző célterületekhez kötődő információk függvényében döntenek majd (Sassen 1995).

A román hallgatók baráti migráns kapcsolatai főként a befogadó hálózatokba ágyazottak (többségük nem román nemzetiségü és az adott országban született); valószínüleg közvetlen migrációs tapasztalaton alapuló kapcsolati tökét jelentenek, és kevésbé befolyásolják a migrációs terveket. Esetükben inkább a migráns kapcsolataik révén tapasztalt informális toborzás növeli a vándorlási szándékot. Viszont a célországgal összekötő kapcsolat hiánya csak kis mértékben csökkenti a külföldi munkavállalás tervezését mindkét csoport esetében, ${ }^{220}$ ami egy kiterjedt migrációs kultúra jelenlétére utal. Ezt erősíti meg a vándorlással mint reális stratégiával való számolás attitüdje, a mintakövető magatartás, illetve a korábbi közvetlen migrációs tapasztalat - többnyire ösztöndíjas részképzés, tanulmányút formájában (Glinos et al. 2011; Galan et al. 2011).

A hiányos idegennyelv-ismeret nem gátló tényező a külföldi munkavállalás tervezésében, és nem is vezet feltétlenül az azonos nyelvű Magyarországra. Tehát nem érvényes erre a vizsgálati csoportra az a korábban tett megállapítás, hogy a magasabb idegennyelv-ismerettel rendelkezők inkább nyugat-európai országokat, míg a gyengébb nyelvismerettel bírók inkább Magyarországot választják célországul (Kiss 2012); vagy legalábbis nincs határozott elkülönülés a két csoport között. Az a feltevésem sem igazolódott be, hogy a román nyelv használatával küszködők inkább Magyarországot választják célországként (Gödri \& Kiss 2009), mert nagyobb arányban mennének Németországba vagy Angliába; bár nem téveszthető szem elől, hogy nagyon kevés hallgatót tartozik ebbe a kategóriába. Viszont az idegen nyelvű média fogyasztása már szignifikánsan kapcsolódik a migráció tervezéséhez: a külföldi médiát fogyasztók nagyobb arányban szándékoznak munkát vállalni külföldön; vagy fordítva: a vándorlást tervezők inkább fogyasztanak idegen nyelvü médiát, ami akár a nyelvtanulást is segítheti. Az interjúk alapján megállapítható, hogy jóllehet az idegennyelv-ismeret mint humán tőke nem közvetíti a származás hatását a külföldi munkavállalási tervekre,

${ }^{220}$ Az erdélyi magyar fiatalok körében a külföldön élő rokon szignifikánsan növelte a külföldi munkavállalás tervezését (kétharmad), a kint élő rokonnal nem rendelkezőkhöz képest (55 százalék). Viszont esetükben nem áll rendelkezésre a migráns baráti kapcsolatokról való adatok, így ennek hatását nem tudtam összehasonlítani az erős kötésével (NKI kutatása). 
viszont szükség esetén bármikor mobilizálható, így elősegítheti a szándék megvalósítását a későbbiekben.

A célországok kiválasztásában általános - egészségügyi dolgozókra jellemző mintákat követnek: a leginkább kedvelt célországok a magyar tannyelvü hallgatók esetében Németország, Anglia, Magyarország és a Skandináv államok; a román hallgatók számára pedig Anglia, Németország, Franciaország és az USA. Németország és Magyarország az erdélyi magyar lakosság körében régóta a leginkább kedvelt célországok (Sik \& Simonovits 2003; Gödri \& Kiss 2009), míg Anglia és a Skandináv államok a román és a magyarországi egészségügyi dolgozók kedvelt célterületei (Rohova 2011; Eke et al. 2011). Ezek alapján megerősítést nyer a Gödriék által tett megállapítás, mely szerint a magyarok a románok által használt migráns hálózatokba is bekapcsolódtak; a két nemzetiség hálózatai összefonódtak, de nem olvadtak egybe (Gödri \& Kiss 2009). Másrészt az is megállapítható - az interjúk tanúsága szerint -, hogy az Európai Uniós csatlakozást követően az egyéni szabad mozgás biztosítása, a képesítések automatikus elismerése következtében kiszélesedett referencia tér, továbbá a nyugati országokban elérhető komparatív előnyök ismerete - a migráns hálózatok meg a fogadó országok toborzási tevékenysége révén közölt információk alapján - (és elsősorban a bérek között levő többszörös különbség) újabb, távolabbi országokba mutató migráns hálózatok kialakulását eredményezte.

Magyarország vonzereje a magasabb béreket kínáló, fejlettebb EU-s országokkal szemben főként az őt Erdéllyel összekötő nagyon kiszélesedett és bejáratott migráns hálózatokban, a romániaitól eltérő szakmai képzési rendszerében (pl. rezidens képzésbe való belépés, szakosodási területek) és a szaknyelvi akadályok hiányában; illetve a közvetlen migrációs tapasztalatok eredményeképpen az idegenség hiányában rejlik.

A taszító tényezők közül leginkább az alacsony pályakezdő fizetés hat, amely még a megélhetésre sem elegendő. A kilátástalannak ítélt jövő - akár Romániában élő fiatalként, akár kisebbségiként - ugyancsak növeli a külföldi munkavállalás tervezésének esélyét. A pesszimista jövőkép nem(csak) a kisebbségi léthelyzetből fakad, hanem erre a fiatal, a gyógyítást hivatásul választó társadalomra nemzeti hovatartozástól függetlenül jellemző. Ezzel összhangban saját jövőbeli helyzetüket egészségügyi dolgozókként a gazdasági javak elosztásában méltánytalannak látják, leginkább az orvostan- és legkevésbé a gyógyszerészeti hallgatók. Elsősorban a 25 éves és annál idősebb, valamint a magas és alacsony társadalmi státusú családból származó hallgatók vélik úgy, hogy méltánytalanul nagy arányban járulnak majd hozzá a társadalom fenntartásához a megtermelt javakból való részesedésükhöz képest. Meglepő módon az aránytalanul nagy teherviselés nem serkenti a migrációs szándékot, amit 
valószínüleg az magyaráz - és az interjúk megerősítik ezt -, hogy a maradni tervezők számításba vették, hogy sokkal többet nyújtanak majd alacsony fizetésükhöz mérten, mint külföldön munkát vállaló kollégáik a nyugati bérekhez viszonyítva.

Megerősítést nyer a korábbi kutatások megállapítása, mely szerint - az iménti megállapításokkal összhangban - a motivációkban szerepet játszó legerősebb vonzó tényezők a külföldön elérhető magasabb bérek, a jobb munkakörülmények és szakmai fejlődés lehetőségei, illetve a magasabb életszínvonal (Rohova 2011; Glinos et al. 2011; Eke et al. 2011). A nőket nagyobb arányban motiválja a magasabb fizetés és a magasabb életszínvonal, míg a férfiakat a szakmai fejlődés. Ez utóbbi tényező nem csak a migráció tervezését, hanem kivitelezésének esélyét is növeli. A magasabb bérek a vizsgálati csoportban elsősorban a magas és vegyes státusúak számára, míg a kontrollcsoport tagjai esetében a vegyes és alacsonyabb státusúak számára jelentenek motivációt a külföldi munkavállalásra. A jobb munkakörülmények és a több szakmai fejlődés lehetősége leginkább a magas státusú családokból származók részére jelent indítékot, akik státushelyzetüket igyekeznek megörizni; a vegyes státusúak pedig elsősorban életesélyeik javítását remélik a migrációtól (Favell et al. 2008): a magasabb életszínvonal és nagyobb szakmai presztízs leginkább őket motiválja. Ez egyúttal azt is jelenti, hogy a magyar nyelvü csoportban a vándorlást a relatív deprivációtól, státusvesztéstől való félelem motiválja inkább, a román tannyelvü hallgatók pedig a felfelé mobilitást remélik elérni általa.

Az elégedetlenséggel kapcsolatos feltételezésem igazolást nyert (Sik \& Örkény 2003): az elégedetlenség kissé, de nem szignifikáns módon növeli a vándorlási hajlandóságot; míg a nagy mértékü elégedettség az otthon maradás szándékát erősíti, kiváltképpen a kontrollcsoportban (Sik \& Örkény 2003). A látogatott intézmények által nyújtott szakmai képzéssel legkevésbé a fogorvos hallgatók elégedettek, ők átlag fölötti arányban jelölték meg Magyarországot célországként. A képzéssel elégedetlenebbek számára fontos motiváció a külföldön elérhető magasabb bérek és szakmai fejlődési lehetőségek. A vándorlással kapcsolatos terveket erősítheti a relatív depriváció vagy az attól való félelem (Guilmoto \& Sandron 2001), de csak bizonyos mértékben, mert a legelégedetlenebbek egyben a legkisebb gazdasági tőkével rendelkezők is, így a mobilitási aspirációik megvalósításához nem rendelkeznek a szükséges erőforrásokkal (de Haas 2011).

A maradás szándékát erősíti, illetve a külföldi munkavállalás tervezésében gátló tényezőként jelenik meg elsősorban a családhoz való ragaszkodás; amely az erdélyi 
magyarok számára a legfontosabb „horgony”221 (Gödri \& Kiss 2009). További fontos visszatartó hatással bír a házas (vagy komoly párkapcsolattal rendelkező) családi állapot $^{222}$ és a szülőföld szeretete; kisebb mértékben pedig a szülőföldön való boldogulásba vetett hit, illetve a rokonság, a kisebbségi magyarság iránt érzett felelősség. A szülőföldjükhöz ragaszkodók nagyobb arányban választják Magyarországot, amit egyrészt magyarázhat a földrajzi közelség, ${ }^{223}$ másrészt viszont a nemzeti- kulturális egységbe vetett hit (Fox 2003).

A külföldi munkavállalást tervezők inkább a helyben maradás mellett döntenének, amennyiben magasabb fizetésre számíthatnának; javítanák és fejlesztenék a hazai egészségügy felszerelését és a munkakörülményeket; kezdő szakemberekként jobban megbecsülnék őket (föként a nővéreket). Az általuk javasolt bérek átlaga a magyar nyelvü csoport esetében 1.500 RON-4.000 RON (kb. 350-900 €) közötti skálán mozog; legnagyobb fizetést a gyógyszerészek, legkisebbet a nővérek jelöltek meg; az orvostanhallgatók átlagosan 2.500 RON (kb. 580 )), a fogorvos hallgatók 2.100 RON (kb. 480 $€)$ kezdő fizetésért dolgoznának otthon. A román tannyelvü fogorvos hallgatók sokkal magasabb, az orvosok ugyanekkora, míg a gyógyszerészek kissé alacsonyabb béreket neveztek meg. Fontos - taszító - tényezők a képzési rendszer jelenlegi müködése (elmélet orientált; a vágyott szakterület választhatóságának kiszámíthatatlansága a rezidens vizsgán; túltermelés, ami a munkanélküliségtől való félelmet táplálja; túlterhelt és/vagy felkészületlen oktatók stb.), amelynek módosításával leginkább a fogorvos hallgatók döntenének a maradás mellett. Az idősebb kollégák támogatóbb attitűdje főként a majdani orvosokat és fogorvosokat bátorítaná az otthon maradásra.

${ }^{221}$ Érdekes módon a kontrollcsoportban csakis a nők esetében müködik visszatartó erőként.

${ }^{222} \mathrm{Az}$ interjúk mutattak rá ennek fontosságára.

${ }^{223}$ Lásd: migráns narratívák (7.3. alfejezet). 


\section{MIGRÁCIÓS POTENCIÁL AZ INTERJÚK FÉNYÉBEN}

A végzős hallgatókkal készült interjúk jól szemléltetik és többnyire megerösítik a migrációs potenciál vizsgálat során feltárt összefüggéseket. Illetve felszínre hoznak olyan különbözőségeket, amelyek a survey eredményeiből nem látszottak. Például a „tervezi a külföldi munkavállalást, de előbb otthon próbálkozik” stratégia mögött eltérő mechanizmusok müködnek. A magyar nyelvü csoport tagjai ténylegesen egy másodlagos lehetőségként említik a külföldi munkavállalást, amennyiben otthoni képzéssel, munkahely kereséssel kapcsolatos - terveiket nem sikerül megvalósítaniuk. A román tannyelvü hallgatók esetében megfigyelhető egy másfajta stratégia: tervezik a migrációt, de előbb szakmai tapasztalat megszerzésére törekszenek otthon, amivel majd könnyebben boldogulnak a külföldi munkaerö-piacon.

„Remélem, hogy nem kell elmenjek. De ha nem kapok munkát, akkor lehet, hogy elmegyek (...) a barátommal. Úgy beszéltük, ha nem kapok munkát, akkor 1-2 év után... és akkor ö is jön velem." (N)

„, [M]indenképpen meg szeretném itthon próbálni elöször. Hogyha viszont eltelik... most nem tudom, nem állitottam fel idöt, mit tudom én, egy év, vagy kettö, hogyha nem találok munkát, akkor azt mondtam, hogy akkor viszont azért fogok elmenni, hogy akkor ott szerezzek valami tapasztalatot, ott nézzem meg, hogy hogy van, de úgy nem húz a szívem igazán. De hogyha szükség lesz rá, akkor megyek, de nem szívesen.” (E)

„Egyelöre nem. Miután szereztem egy kis tapasztalatot és már magabiztosnak érzem magam abban, amit csinálok, akkor igen. Nem akarok menni és csúfot üzni valakiböl a munkámmal azért, mert nincs tapasztalatom." (F)

A migráns hálózatok jelenléte és szerepének fontossága itt is megragadható, illetve arra is fényt derít, hogy miért hatnak különbözőképpen a rokoni és baráti kapcsolatok. A migrációs potenciál vizsgálata kapcsán kiderült, hogy a migráns baráti/ismerősi kapcsolatok inkább növelik a külföldi munkavállalás esélyét, mint a rokoni hálózatok. Az interjúk alapján a gyenge kapcsolatok ereje annak tudható be, hogy többnyire kollegiális viszonyt foglalnak magukban, így az egészségügyi szektorban, külföldön dolgozó kolléga nagyobb tőkeforrást jelenthet - már csak 
informátorként is -, mint a kint élö/tartózkodó rokon, akivel esetleg nem is aktív a kapcsolattartás. Nem hagyható figyelmen kívül a származás avagy osztályhelyzet hatása sem, amelyet a migráns hálózatra gyakorol. A kérdőív eredményei ugyan nem mutatnak rá, de az interjúk alapján a társadalmi státusnak megjelenítője lehet a kapcsolati tőke (Portes 1998). A magas státusú orvos szülők gyermekei közvetve szüleik migráns baráti-kollegiális tőkéjét is mobilizálhatják, míg az alacsonyabb származásúak számára a külföldön dolgozó családtagjaik sem feltétlenül jelentenek mobilizálható tőkét az egészségügyi munkaerőpiacra való belépéshez (pl. idénymunkás). Illetve a gazdasági tőke hatását is ezek összefüggésében kell szemlélni. Korábban a logisztikus regresszióelemzés rámutatott arra, hogy bár az alacsony társadalmi háttér növeli a külföldi munkavállalás tervezésének esélyét - legalábbis a magyar nyelvü minta esetében -, a szegénység ezzel ellentétesen hat (Portes 1998). ${ }^{224}$

„,[A] fivérem ment el 4 évre Görögországba, egy sörgyárban dolgozott. Hazajött mert már nem volt ott több munka és nem talált munkát máshol sem, és most is munkát keres, vagy ott vagy itthon" (R)

„Mindenki emigrál [családjából] Olaszországba és Spanyolországba. És épittkezéseken dolgoznak és ilyesmi. Föleg építkezéseken." (H)

„[A]nyukám elsö asszisztensnöjének, ök kiköltöztek még régen, és neki a fia vezet egy klinikát. Ugye nálunk kötelezö nyáron egy hónap gyakorlat, és akkor megszerveztük úgy, hogy oda menjek. Azt mondták, hogy nagyon szimpatikus vagyok, meg minden, és hogy várnak akkor egyetem után oda dolgozni. (...) [I]smerösökkel volt beszélve, hogyha esetleg kell valakinél lakni, akkor legyen, a rendelöben is, ha kell felszerelést vegyek, vagy anyagokat, vagy valamit, akkor hogy honnan lesz töke, amiböl majd vásároljak, ilyeneket" (D)

Az interjúkból látható, hogy az anyagi nehézségekkel való küszködés eltérő stratégiákhoz vezethet. Némely esetben - a kiterjedt migráns kapcsolati hálózat dacára a helyben maradás szándékát eredményezi, vagy a migráció mint másodlagos, „B-terv” jelenik meg a potenciális migráns számára. ${ }^{225}$ Ezek az interjúalanyok maradási

\footnotetext{
${ }^{224}$ Portes a hivatkozott tanulmányban a migráns etnikai csoportok és hálózatok kapcsán írja le, hogy a gazdasági tőke hiánya gyakran együtt jár a társadalmi kapcsolatok szükösségével, illetve hozzájuk hasonló helyzetben levőket foglalja magába, így gyakran még a migrációhoz szükséges információk sem jutnak el hozzájuk.

${ }^{225}$ Erről korábban az „előbb otthon próbálkozó” stratégia kapcsán volt szó.
} 
szándékukat a szülőföldhöz való kötődéssel, kisebbségi létük felvállalásával, családjuk iránt érzett felelősséggel indokolják. Olyan eset is van viszont, amikor éppen fordítva, a szegénység a külföldi munkavállalás aspirációját erősíti - még a migráns kapcsolati tőke hiányában is -, amely a nehézségekből való kiutat jelentheti.

„Itt szeretnék maradni, mert ez nem időveszteség, össze kell gyüjtenem az anyagi fedezetet az elmenetelhez. Hogyha itthon maradok egy-két évet, tapasztalatot is szerzek, még akkor is, ha nulláról kell kezdeni valahol máshol (...) Biztos vagyok abban, hogy hogyha egyszer elmegyek nem valószinü, hogy visszajönnék az országba. ” (R)

„, [Í]gy elgondolkodtam rajta, de olyan szinten tudom, hogy hosszú távra nem mennék ki külföldre, esetleg bevállalnék egy rövid intervallumra egy ösztöndíjat, egy fél évre, három hónapra, de hosszú távon nem... nem szándékozom elmenni. Túlságosan is kötődöm egyrészt a családomhoz, édesanyámhoz, a közösséghez, a szülőföldemhez és a magyarságomhoz. Tehát nekem szükségem van bizonyos keretekre, amik annyira közel állnak a szivemhez, hogy én ezeket nem szeretném feladni anyagiakért (...) igyekszem nem itélkezni, de néha azért van egy ilyen frusztráltság bennem, hogy hát igen, mindenki megy, mert könnyü, és igazából maga ez, hogy magyarnak lenni. Tehát könnyü magyarnak lenni például külföldön, amikor egy kisebbségben megvan az anyagi háttér, mert már évek után kerestek maguknak sok pénzt, és akkor utána hazajönnek, és akkor milyen jó nekik. De hát igazából nem vállalják azt a harcot magyarként például itt Erdélyben kisebbségben. De hát igyekszem nem itélkezni, és mindig az embert nézem, és nem azt, hogy akkor most milyen funkciója van, vagy mennyi a fizetése.” (G)

„,[M]indenhol vannak beteg emberek, de úgy gondolom, hogy itthon azok, akik között esetleg, ha például hazamennék, akkor azok között, akiket ismerek, azok között, akik között élek, rajtuk tudnék segiteni (...) Én saját magam nem érezném magam otthon, merthogy nem az én otthonom, nem az én országom, és bármennyire is jól telne, biztos hiányozna a szülöföldem, hiányoznának azok az értékek, amiket itt megtapasztaltam, amiket itt megéltem, azok az emberek, azok a barátok, azok a családtagok” (E)

A potenciális migránsok válaszaiban megjelennek a migrációs kultúra elemei, amelyek: a migrációról szóló ismeretek, a vándorlás mint orientáció/ életstratégia, illetve a migrációhoz kapcsolódó értékek (Massey et al. 1994). Sokoldalú ismerettel rendelkeznek a külföldi munkavállalásról, amelyeket általában közvetlen vagy közvetett (kollégáik révén) migráns hálózatuk révén szereznek be, illetve ha komolyabban 
tervezgetik, akkor a világhálón is böngésznek vagy tervezik felvenni a kapcsolatot munkaerő-közvetítő ügynökséggel. Migrációs szándékuk indoklásában makroszintü különbségek szerepelnek - a Nyugaton elérhető magasabb bérek -, a román egészségügyi rendszer müködési problémái, infrastrukturális valamint pénzügyi hiányosságai, korrupció, a relatív depriváció (elsősorban anyagi és szakmai), a képzési rendszer diszfunkciói, a migráció elterjedtsége (más is ezt az utat választja); ${ }^{226}$ sőt, még oktató részéről tapasztalt ezirányú bátorítás is.

„,[R]engeteg apróság, amit akkor él át úgy igazán az ember, amikor látja, hogy itt milyen egy rezidensnek, és hallja ismeröseitöl, hogy külföldön milyen, kezdve attól, hogy van öltözö a rezidenseknek, van saját szekrénye. Itt nincs saját szekrénye, haton vannak egy szekrényben. Apróságok is hozzájönnek mindehhez, és az, hogy itt egy rezidens elsö években csak papirmunkát végez, ott pedig a rezidens első évtöl, amikor már átveszi a rendszert és már nincs problémája a nyelvvel, akkor nemcsak papírmunkát, hanem betegekkel is dolgozik, persze, ha olyan szakon van.” (C)

„[I]tthon nem nagyon lehet munkát találni, és arra a kevés helyre protekcióval lehet bejutni- ezt láttam én 4 év alatt naponként- hogy a különbözö szakosztályokra protekcióval jutnak be, és nincsenek helyek. Másfelöl meg a fizetések nagyon alacsonyak külföldhöz képest, ahol háromszor, négyszer annyit kapsz. ” (B)

„Épp ma hallottam egy esetet, 2000 eurós fizetés... orvost vettek fel, 2000 eurós kezdő fizetéssel, és onnan még lehet növekedni." (J)

„,[E]gyfelöl a tanáraim sugallják, hogy külföldre kell menni, kell képezni magunkat, hogy lássuk, hogy külföldön milyen lehetöségek vannak, és azt a tudást, ha tudjuk, hozzuk haza. Tehát ez végül is nem egy olyan rossz dolog szerintem, csak a lényeg az, hogy meg kell találni a lehetöséget arra, hogy visszacsalogatni, hazahozni azokat az orvosokat, akik külföldön összegyüjtötték a tudást, hogy hazajöjjenek és itthon hasznositsák azt." (C)

A szakmai relatív depriváció egyik forrása - a már átvándoroltak által is említett korábbi szakmai migráció. A különböző nemzetközi hallgatói mobilitási

226 Mindezek nagymértékben megegyeznek a már elvándorolt egészségügyi dolgozók révén megfogalmazott migrációs motivációkkal (lásd a 7. fejezetet). 
ösztöndíjprogramok egyik hatása, hogy kitágítják az egyén referencia alapját, elvezetve a relatív depriváció megszületéséhez vagy megerősödéséhez. ${ }^{227}$

„Az ötlet talán befolyás alapján is jött, mert nagyon sokan elmennek, de legföbb ok az, hogy voltam Erasmus ösztöndíjjal Franciaországban $M$ egyetemen. És ennek köszönhetően eldöntöttem, hogy ,,Igen, el akarok menni”, mert látom a különbséget az ö és a mi egészségügyi rendszerünk között. Hasonlitgatva és kérdezösködve az a benyomásom, hogy így van más országokban is. És akkor eldöntöttem. ” (R)

„,[N]agyon szerencsés vagyok, mert ismeretségen keresztül tavaly nyáron kikerültem egy budapesti klinikára, és ott felajánlottak egy munkát (...) Ugye nálunk kötelezö nyáron egy hónap gyakorlat, és akkor megszerveztük úgy, hogy oda menjek.” (D)

A szakmai relatív deprivációt kiválthatja nemcsak a személyes migrációs tapasztalat, hanem a szakmai képzés révén nyújtott ismeretek és az egészségügyi rendszer infrastruktúrája közötti diszharmónia. Migráció- kutatók megállapították már, hogy a magasan képzettek migrációs szándékát erősíti, hogy jóllehet a képzés során a nyugati, modern módszereket sajátítják el, ennek a tudásnak a gyakorlati alkalmazására nincs lehetőség a megfelelő, fejlett felszerelések hiányában (Portes \& Böröcz 2001).

„Pillanatnyilag Romániában szerintem az a helyzet, hogy semmiféleképpen az orvosok nem tudnak boldogulni (...) Szeretném kielégiteni a szaktudásomat, és szeretném elérni azt, hogy bármilyen gépet, bármit tudjak használni arra, hogy egy beteget tudjak meggyógyítani vagy legalább diagnosztizálni, ne legyen az a probléma, mint ami esetleg itt fennáll, hogy évekig egy ember szenved és nem tudja még a diagnózist sem. És akkor még ne is beszéljünk a megoldásáról ennek a problémának.” (S)

A relatív deprivációnak végül egy további forrása a korábban is említett migráns hálózatok és az általuk közvetített információk, tudáshalmaz. A migráció elterjedtségére utal a vizsgált közösségben, hogy sok minden „köztudott” számukra, a külföldi munkavállalás ügyét csoportosan fontolgatják; sőt, egyesek már „szakértenek” a kivándorlási adatokban.

${ }^{227}$ Lásd korábban HR szövegét. 
„Föként az a téma, hogy milyen térségben keressünk munkát, inkább most ez a téma, és aztán nem tudom, így, ahogy beszélgettünk, még nem beszéltem olyannal, aki azt mondta volna, hogy ö most, jaj istenem, külföldre szeretne mindenféleképpen menni. Mindenki azt mondta, hogy inkább megpróbálja itt, és akkor hogyha itt nem jön össze, akkor ott. Vagy hogyha olyan lehetöség adódik, akkor ott." (Q)

„, [Ú]gy az évfolyamtársakkal is úgy beszéltük, hogy egyedül senki nem menne. Hát úgy van mindenki, hogy ha esetleg még ketten-hárman mennének, akkor még esetleg megpróbálnák, de egyedül nem." (E)

„Nálunk a tendencia az, ahogy egy felmérés is kimutatta, hogy minden ötödik órában elhagyja az országot egy orvos, és az egyetemisták több mint 70 százaléka akar külföldre menni, mert a fizetések nagyon alacsonyak. Bármilyen EU-s országhoz hasonlitva, azt hiszem, itt a legalacsonyabb. A kórházakban a körülmények hagynak kívánnivalót maguk után, és a társadalom részéröl is az orvos nem örvend egy olyan megbecsülésnek, amit esetleg kiérdemelne. (...) [M]ert az évfolyamunkról a mostani végzösöknek nagyon nagy része, tíz emberböl hét azt mondja, hogy megy el. És ez óriási szám. És akkor ki marad itthon? Mert itthon is szükség van orvosokra, söt, egyre nagyobb." (C)

Így a migráció mint életstratégia a hallgatók számára egy olyan természetes kérdésként vetődik fel, amivel mindenképpen számolniuk kell és dönteniük (Bodó 2008). Persze ez a döntés időben nem állandó, sőt folyamatosan változik új információk, adott körülmények és lehetőségek változásának hatására. Viszont a vándorlás életstratégiaként legitimmé és többnyire elfogadottá vált körükben; erre utalnak a migránsokról alkotott véleményeik. Bár némely hallgató - amint már eddigi idézetekből látható - a szülőföld, a család vagy a hazai betegek iránti felelősség nevében az otthon maradás - vagy csak rövid távú migráció - mellett foglal állást. ${ }^{228}$

„Hát most amióta otthon kaptam [állás]ajánlatokat, azóta gondolkodom, hogy maradjak itthon, és utána. Úgyhogy ezen most a hónapokban kezdtem gondolkodni, hogy maradjak.”(O)

${ }^{228}$ A közösségükért felelősséget érzők a vegyes és alacsony származású hallgatókból állnak. 
„Egyre inkább, az az igazság. Tehát lehet, hogyha egy évvel ezelött beszéltünk volna, akkor még azt mondtam volna, hogy nem, nem, semmi szín alatt” (P)

„Van, akit tisztelek, hogy volt bátorsága elmenni. De van olyan, aki szerintem próbálkozhatott volna egyszer itt, s ha nem jött volna össze, akkor menjen ki. Nem hogy egyböl már kimennek” (N)

„Nem értek egyet ezzel. Ha meg lehet élni, miért ne éljünk itt? Miért menjek oda, dolgozzak idegeneknek, mikor itt a mi hazánk? Itt elvégzem az iskolát, aztán dolgozzak ott?" (M)

A házastárs visszatartó ereje - föként ha kevésbé mobilizálható tökével rendelkezik abban mutatkozik meg, hogy képes más családtagok migrációja esetében is „helyhez kötni" a társát.

„,Nem akarok elmenni. Jövőben férjhez megyek, és nem” (M)

„A szüleim elmentek, Olaszországban vannak már 10 éve (...) A férjem... Itt van vállalkozása, itt van minden, és egyelöre még... Mindent itt kellene hagyjon miattam, tudod, és egyelöre tudnék boldogulni itt is.” (I)

A külföldi munkavállaláshoz olyan remélt nyereségek és értékek füzödnek mint a szakmai fejlödés és magasabb társadalmi-gazdasági megbecsültség elérésének lehetősége, egy meritokratikusabb munkaerő-piacra való belépés és anyagi jólét; bátorság, de ugyanakkor a „könnyebb út” választása, „,modern rabszolgaság” is egyben.

„[E]löször, ami legelöször eszembe jut, az az, hogy tényleg bátrak, de ez felfogás kérdése is (...) Van, akiben úgy benne van ez a kalandvágy.” (Q)

„[N]agyon sokszor szembesültem avval, hogy az elözö évben végzett barátaim, ismerőseim nagy része külföldet választotta, meg a csoporttársaim is gondolkoznak azon, hogy külföldre menjenek. Így én is szembesültem azzal a kérdéssel, hogy igen, de hogy leszel-e az a hülye, aki itthon marad és küzd. És ma avval is szembesülök, hogy minthogy fontolom azt, hogy itthon maradjak, fel kell készüljek arra, hogy sokkal nehezebb lesz, kisebb lesz a fizetés, és meg kell kezdjem a saját harcaimat. (...) [M] indenkinek a saját döntése, mindenkinek jogában áll és szabadságában áll, hogy mit 
választ, mik a prioritások. Én úgy gondolom, hogy egyrészt... nem lehet itélkezni sem, hogy most könnyü a könnyebb utat választani, merthogy milyen nagyok a fizetések külföldön is, hogy milyen jó megbecsültség, mert mindennek megvan a maga ára. Tehát hogy egyrészt az sem semmi, aki vállalja azt a cécót, hogy minden papirt elintézni, egy idegen környezetbe beilleszkedni, nyelvet megtanulni, ez nem kis áldozat. Tehát ezért ilyen szempontból becsülöm azt, aki ezeket az áldozatokat meghozza és sikeresen helytáll, ennyi kihívásban." (G)

\subsection{A migrációhoz való attitüdök típusai}

\subsubsection{Az egyéni érdekkövetö}

Egyfajta jóléti migránsnak fogható fel (Gödri \& Tóth 2005; Kovács \& Melegh 2001); 10 fö tartozik ebbe a típusba. Az anyagi jólét az, ami motiválja a külföldi munkavállalásban, de szerepet játszik - mintegy felerősítve emezt - még a megváltozott referencia tér ${ }^{229}$ és a helyi egészségügyi rendszer észlelt hiányosságai; ez utóbbi taszító tényezőként müködik. A képzési rendszer nem megfelelő müködése némely esetben mintegy „rákényszeríti” az egyént a vándorlásra - a hallgató legalábbis nem lát más utat -, mivel vagy nem teszi lehetővé a szabad szakmaválasztást, ${ }^{230}$ vagy nem biztosít a végzősök számával arányos továbbképzési helyet. ${ }^{231}$ Elbeszélésében és válaszaiban általában egy aktív, a cselekvést kezdeményező szerepében jeleníti meg önmagát. Passzivitás a pályaválasztás során jön elő: valaki meggyőzte vagy rábeszélte az adott szakmára. De főként a mintakövetés (magasabb státusúak esetében többnyire valamely szülőé, alacsonyabb státusúak esetében valamely rokoné vagy osztálytársaké) áll a pályaválasztása hátterében. A migráns hálózatok, a célországgal összekötő főként baráti és ismerősi kapcsolatok információs csatornákként és mobilizálható vagy már ténylegesen mobilizált társadalmi tőkeként müködnek (Gödri 2010). A kapcsolati tőkeszegénység, főként ha szűkös gazdasági tőkével társul, ,álomszerűvé” teheti a migráció gondolatát, vagy éppenséggel megszilárdítja a külföldre vándorolni vágyó szándékát. Kiszemelt célterülete Anglia vagy angol nyelvterület, Németország, Svédország és

\footnotetext{
${ }^{229}$ A külföldön élő lehetőségek megismerése és tudatossá válása a határokat átívelő információk révén, kitágítják az egyén aspirációinak körét (de Haas 2011).

${ }^{230}$ A szakosodást biztosító rezidens-képzési rendszerbe való belépés egy országos szintủ vizsgán elért pontszámok alapján müködik. A legnagyobb pontszámot elért rezidens- jelölt választ elsőként a meghirdetett szakterületek és a képzést nyújtó intézmények közül, és így tovább, egyre inkább szükülnek a választási lehetőségek, míg végül betelnek a meghirdetett helyek. Azok, akik elérték ugyan a minimálisan elvárt pontszámot, de már nem jut számukra hely, automatikusan családorvosi szakképzésbe kerülnek. Dönthetnek, hogy elvégzik-e azt, vagy ismét tanuláshoz látnak, és egy év múlva újra próbálkoznak a rezidens vizsgán.

${ }^{231}$ A képzési rendszer ,elszűkülését” az elvándorolt román orvosok is említették migrációs motivációik sorában (Glinos et al. 2011; Rohova 2011).
} 
Magyarország. Elsősorban a státusmegőrzők, tehát a magasabb státusú szülők gyermekei közül kerül ki. Alacsonyabb státusúak esetében az anyagi helyzet javításának szándéka mögött a jelenben/múltban megtapasztalt anyagi gondok állnak. Közép (4-5 év) és hosszútávú (több mint 6 év, esetleg végleges) migrációt tervez. Ebből eredően az életét öt év múlva itthon, de némely esetben külföldön (csak erre a típusra jellemző) képzeli el. A külföldi munkától az anyagi körülményeinek javulását, jobb munkakörülményeket, munkája megbecsülését és szakmai fejlődést remél.

\subsubsection{Maradni szándékozó}

Az interjúalanyok közel egyharmadát kitevő csoport (6 fö). Terveikben elvetik az elvándorlás gondolatát; legfennebb egy néhány hónapos ösztöndij/ tapasztalatszerzés formájában jelenik meg. Viszonylag kiterjedt migráns kapcsolati tőkével rendelkeznek. ${ }^{232}$ Némelyek említették, hogy anyagi nehézséggel küzd családjuk, illetve egyszülős családból származnak. ${ }^{233}$ Valamennyi társadalmi státusú családból jövő és szakterületủ hallgató jelen van ebben a csoportban. ${ }^{234}$ Maradásra késztető tényezőként müködik a már házas családi állapot - alátámasztva a kérdőíves felmérés eredményeit -, vagy egy komoly párkapcsolat megléte. Indoklásukban jelen van a szülő(k) vagy a tágabb közösség iránt érzett felelősség, a szülőföldhöz való ragaszkodás. A külföldi munkavállalás előnyeit - a vándorolni szándékozókhoz hasonlóan - a jobb anyagi körülményekben, a szakmai fejlődési lehetőségekben és kedvezőbb munkakörülményekben, egy meritokratikus munkaerőpiacban és magasabb életszínvonalban látják. A migráció legfőbb hátrányainak a családtól, otthontól való elszakadást, a jelenlegi kapcsolatok elveszítését/átalakulását, a befogadó társadalomban a bevándorlókra váró kommunikációs és beilleszkedési nehézségeket, valamint az idegenség érzését tartják. A mintakövetés hiánya (az ,árral szemben való úszás” attitüdje - hiszen a migrációs kultúrában nehéz a maradás mellett dönteni, és a vándorlás könnyebben járhatónak tünik) némelyiküknél már korábbi döntéseikben, pontosabban a pályaválasztásban is megnyilvánul, amikor úgy döntöttek az egészségügyi pálya mellett, hogy nem állt elöttük egy családi vagy rokoni példakép,

\footnotetext{
${ }^{232}$ A kereszttáblás elemzések eredményeként azt a következtetés született a vizsgálati csoportot illetően, hogy a helyben maradás vagy az előbb otthon próbálkozás mellett nagyobb arányban a kapcsolati tőkeszegények döntenek, viszont a kontrollcsoportra nem állt ez az összefüggés. Az interjúk során viszont a helyben maradást tervezők között mind a magyar, mind a román hallgatók rendelkeztek különböző migráns kapcsolatokkal. Erre a látszólagos ellentmondásra magyarázatul szolgálhatnak az egyéb tényezők hatásai, mint az átlagosnál rosszabb anyagi helyzet vagy a házas családi állapot a maradni szándékozók esetében.

${ }^{233}$ Olyan eset is van, hogy mindkettő jellemző rá.

${ }^{234}$ Gyógyszerész hallgatók említették a maradás okaként a már állással rendelkezést vagy annak biztosításáról való ígéretet.
} 
sem osztálytársaik mintája, hanem szeretteik szenvedése, a másokon segíteni akarás vagy egyéb tényezők motiválták. Úgy jelenítik meg magukat mint jelenlegi helyzetükkel elégedett, megállapodott fiatalok vagy szüleik, esetleg nemzetük iránt felelős jövendőbeli szakemberek.

\subsubsection{Kényszer migráns}

Két típusa különböztethető meg. Az egyik típus az egészségügyi képzési rendszer részéröl érzi kényszerítve magát, a másik típus a párkapcsolata révén.

10.1.3.1. A rendszer jelen müködése alapján nem látják biztosítottnak foglalkoztatásukat a román munkaerőpiacon a nővérek. A magyar tannyelvű nővérek esetében figyelhető meg a migráció olyan stratégiaként, amely - és kizárólag - a hazai egészségügyi rendszerbe való belépés sikertelen kísérletét követően mobilizálódik. Egyfajta „kényszerpálya” vagy „menekülési útvonal” szerepét tölti be ez esetben, és így bizonyos értelemben átmenetet képez a maradni szándékozók és a vándorlást tervezők között, hiszen az elsődleges szándék itt is a szülőföldön maradás, és önbemutatásukban is - az előző típushoz hasonlóan - a megállapodott, illetve a családja és saját népe iránt felelős ember képét ábrázolják. Ezt támasztja alá jól informáltságuk a diplomázást követő ügyintézésről, amely a hazai munkaerőpiacra való belépéshez szükséges. Célországként Németországot és Angliát nevezték meg, viszont egyikük sem indulna el egyedül, hanem párjukkal vagy testvérrel, baráttal vállalkoznának a külföldi munkavállalásra, amit néhány éves időtávra terveznek. A várt nyereségek között az anyagi és szakmai tényezőkön túlmenően megjelenik a nyelvtanulás, illetve a betegséghez való másfajta attitüd - mind a betegek, mind pedig az egészségügyi dolgozók részéről - megismerése.

A magyar tagozaton tanuló nővérek részben elégedetlenek a képzés struktúrájával: túlságosan elmélet- és orvos- centrikusnak tartják, és véleményük szerint kevesebb gyakorlati ismeretre és tapasztalatra tesznek szert, mint az egy évvel rövidebb képzést nyújtó egészségügyi föiskolák hallgatói. Ennek fő okait a képzési központ túlzsúfoltságában, az oktatók túlterheltségében, a kisegítő személyzet elégtelenségében és a belső hierarchiában zajló hatalmi harcokban látják. Az egészségügyi rendszer müködéséről való kritikát és pályakezdőként a munkanélküliségtől való félelmet osztják a román nővér hallgatók is. Egy belső inkonzisztenciát látnak: a képzésben egy „túltermelés” folyik, amit a rendszer nem képes felszívni, és amely kedvező teret nyújt a korrupciónak $^{235}$ és a migráció irányába hat.

${ }^{235}$ A korrupciót és protekciót a külföldön dolgozó román egészségügyi dolgozók (Rohova 2011), illetve az erdélyi magyar migráns interjúalanyok is említették. 
Másfelől nem nevezhető egyértelmüen túltermelésnek, mert az ezer lakosra jutó nővérek arányszáma Romániában nagyon alacsony (lásd 3. ábra), és az egészségügyi rendszer alulfinanszírozottságának egyik következménye az elérhető munkahelyek számának szükössége. A nővérek - de általánosságban az egészségügyi dolgozók túlterheltsége migrációra ösztönző tényező lehet, amely öngerjesztő folyamattá válhat, hiszen az elvándorlás következtében még jobban megnövekszik az egy före jutó páciensek száma, túlterheltség stb. (Greco 2010).

Ebben az esetben viszont, amikor úgy érzik, hogy nincs szükség az ő munkaerejükre, talán inkább felmentik magukat migrációs döntésük etikai felelősség alól. ${ }^{236}$

10.1.3.2. Kapcsolat-vezérelt (1 fö): az elvándorlás tervezését egyfajta kapcsolatkényszerként éli meg; párja indítványozására kezdett el foglalkozni a migráció gondolatával. Döntésében a párja részéről érkező befolyás mellett szerepet játszik a férfi külföldön élő rokonainak hívogatása; továbbá attól való félelme, hogy szakorvosként sem lesz lehetősége állást találni szülővárosában. Célországa Magyarország, mivel egyfelöl párját elsősorban a kulturális/ nyelvi integrálatlanság (Kiss \& Csata 2004) motiválja a külföldi munkavállalásra; másfelől meg saját félelmeit, aggodalmait fejezte ki egy más kultúrába való beilleszkedés kapcsán. Így az anyaország válik célterületté, „,mert úgy érzem, hogy ott mind a ketten megtalálnánk a helyünket” (P). A külföldi munka hátrányaiként az idegenség, otthontalanság érzését emeli ki, amelynek veszélye még az azonos nyelvi környezetben is fennáll. A migrációt egy nagy töréspontnak látja életútjában: ,, [M]ár úgy érzem, hogy abban a korban vagyok, így van egy igényem arra, hogy valahol gyökeret verjek, és most ez olyan lenne, minthogyha a semmiböl épiteném fel az egészet megint, és ez valahogy nem része annak a normális életszakasznak, amit bárki úgy átél” (P). Jövőjét és terveit illető bizonytalanságát jól tükrözi, hogy ő az egyedüli, aki nem tud hozzávetőleges választ sem adni arra, hogy hol, melyik országban képzeli el az életét öt év múlva.

\subsubsection{Kalandvágyó}

Egy másik sajátos eset, amelyik egyik korábbi típusba sem sorolható; a kíváncsiságot nevezte meg a vándorlási szándéka mozgatórugójaként. Egyfajta belső feszültség figyelhető meg a hallgató válaszaiban, amely az aspirációk és lehetőségek között álló konfliktusból származik ${ }^{237}$ és egy ide-oda csapongást szül a gondolatvezetésben. Kalandvágya a tengerentúlra hajtaná, viszont társadalmi és humán (szakmai nyelv

\footnotetext{
236 Egy kutatás eredményei alapján a több éve külföldön dolgozó román orvosok véleménye szerint migrációjuk nem etikai kérdés. Úgy vélik, hogy joguk van saját lelkiismeretük szerint dönteni, és oda menni, ahol érdekeiknek megfelel és szakmailag is előnyösebb számukra (Cehan 2013).

${ }^{237}$ Lásd az elméleti részben Festingernek a kognitív disszonanciáról való elméletét.
} 
ismerete) tőke hiányában, amihez valószínűleg gazdasági tőke-szegénység is társul, ${ }^{238}$ ennek megvalósítása inkább vágyálommá válik a maga számára is. Bár célterület tekintetében nagyban különbözik a kapcsolat vezérelt kényszer migráns típusától „Én úgy gondoltam, ha már megyek, akkor megyek. Tehát ott is, én amennyire tudom... nem hiszem, hogy kimennék Magyarba dolgozni, vagy nem tudom” (T),

más szempontból viszont több hasonlóság is megfigyelhető e két egyedi ${ }^{239}$ motiváltságú potenciális migránsnál. Bizonytalanság (gyakori „,nem tudom”-ok) és konfliktus hatja át mindkettőt, egyik esetben a vágyak és lehetőségek közötti feszültségből, másik esetben a vándorlással járó áldozat, illetve a migrációhoz kapcsolt félelmek miatt. A külföldi munkától várt előnyök tekintetében is sajátos ez a két típus; a más fajta tapasztalatok megszerzését emelték ki elsősorban, de a magasabb kereseti lehetőséget, és egy másfajta attitüd megismerését is említették.

\section{2. Összegzés: a migrációról való gondolkodás és a „befejezett” migráció közötti fontosabb összefüggések}

A migrációs kultúra jelenléte és hatása figyelhető meg mind a migránsok, mind a végzős hallgatók körében. Az EU-n belüli szabad mozgás és a képesítések szállíthatóságának következtében még inkább kitágult a referenciatér a potenciális migránsok számára, és olyan nyugat-európai országokat tűznek ki célországul, amelyek a korábban migráltak számára egy szekunder migrációval, azaz továbbvándorlással érhető el.

A külföldi munkavállalás tervezésének fő motivációi a globális egyenlőtlenségekből erednek - úgymint az országok közötti bérkülönbségekböl, az egészségügyi rendszerek felszerelése közötti különbségekből, a szakmai relatív deprivációból. Szerepet játszanak ezentúl a képzési rendszer hiányosságai, a korrupció, a kilátástalannak vélt jövő, a fennálló migráns hálózatok toborzásos tevékenysége; továbbá a párkapcsolat által kiváltott „,kényszer”240 és a kalandvágy. Így a vándorláshoz füzött remélt nyereségek elsősorban a magasabb bérek (jólét), a szakmai fejlődés lehetősége, magasabb társadalmi-gazdasági megbecsültség elérése és egy meritokratikusabb munkaerőpiacra való belépés.

Ezek többségét a már migrált egészségügyi dolgozók narratívái visszaigazolják. Jóllehet esetükben az elsődleges motivációt a párkapcsolat (család) jelentette, a továbbvándorlást fontolgatók számára ugyanúgy a globális hierarchiákból eredő

\footnotetext{
${ }^{238}$ Erre engednek következtetni a rokkant anya, és a külföldön elérhető magasabb jövedelem említése.

${ }^{239}$ Ezalatt természetesen csak a mintába választott interjúalanyok sokaságát értem mindössze

${ }^{240}$ Lásd RI és P interjúját.
} 
különbségek (Nyugat-Kelet) a migráció tervezésének okai; és többé- kevésbé rejtetten már az anyaországba vándorlásuk esetében is szerepet játszott. ${ }^{241} \mathrm{~A}$ már továbbvándorolt, korábbi évfolyamtársak migráns hálózatain keresztül áramló információ a relatív depriváció megerősítését szolgálja. Magyarországra vándorlásuk értékelésében - a nővérek kivételével - úgy vélik, hogy gazdasági és szakmai előrelépést, fejlődést eredményezett számukra a migráció (a maradáshoz képest). A potenciális migránsok által remélt társadalmi- gazdasági megbecsültséget csak kevesüknek sikerült elérnie; és ugyancsak a nővérek hagsúlyozták leginkább ennek hiányát. Az anyaországi képzési rendszert és egészségügyi munkaerőpiacot meritokratikusnak vélik, amelybe ők a magyarországi hallgatókéhoz hasonló eséllyel léphettek be ${ }^{242}$ versenyezhettek a meghirdetett állásokért.

A potenciális migránsok a vándorlás hátrányaiként a családtól, az otthontól való távollétet, a korábbi kapcsolatok átértékelődését, illetve megszakadását, a beilleszkedéssel, alkalmazkodással járó nehézségeket, továbbá a diszkriminációt, az idegenség, magányosság érzését, a kommunikációs problémákat és az esetleges kudarcot nevezték meg.

A migránsok történeteiben a családtól való elszakadás vagy ragaszkodás jelenik meg a leghangsúlyosabban; ez utóbbiak esetében a visszatérés szándékának vagy a továbbvándorlás tervének elutasítását, az előzőeknél pedig egy lebegő-sodródó léthelyzet kialakulását eredményezve. Egyik orvos lelkiismeret furdalást is említ szülei elhagyása miatt.

A beilleszkedéssel, alkalmazkodással járó nehézségek is megjelennek egy-egy migrációs történetben; illetve a kudarcélmény is. ${ }^{243}$ Ugyanakkor az erdélyi identitáshoz való ragaszkodás illetve a sodródó léthelyzet kapcsán az is megállapítást nyert, hogy az átvándorolt egészségügyi dolgozók nagy részének integrációja a magyar társadalomba csak szakmai- munkahelyi szinten valósult meg. Kommunikációs nehézségeket Magyarország kapcsán az azonos nyelvre való tekintettel nem említettek. Viszont szerepet játszott Magyarországnak célországként való választásában, illetve a továbbvándorlás gátjaként is megemlítették. A befogadó társadalom részéről tapasztalt etnikai diszkriminációról általában csak kérdezés révén számolnak be. Ennél sokkal hangsúlyosabb szerepet kap a kibocsátó társadalom részéről megnyilvánuló diszkrimináció.

\footnotetext{
${ }^{241}$ Lásd pl. BA és AO interjúját.

${ }^{242}$ Kivételt képez a honosítási eljárás alatti időszak, amikor a hivatalos státusuk nem felelt meg a valódi munkakörüknek. Illetve TC esetében az adminisztrációs követelmények ismeretének hiányában hiúsult meg a felvétele egy adott kórházba.

${ }^{243}$ Ez utóbbihoz lásd BA, RT vagy AO interjúját.
} 
A kollegiális migráns hálózatok hatása a külföldi munkavállalás tervezésére az információ közvetítésben és a toborzásban jelenik meg, a relatív depriváció kialakulását vagy megerősítését eredményezve. Továbbá szerepet játszanak a korábban beindult migrációs folyamatok önfenntartóvá válásában, valamint a migrációs kultúra terjedésében.

A megvalósult migráció - amely esetében ezek a migráns hálózatok többnyire összefonódnak a párkapcsolati vagy testvéri viszonyokkal - megerősíti nem csak az informátori és toborzásos tevékenységét, hanem mobilizálásával csökkentek a migráció anyagi és pszichológiai költségei. Elősegítették az előzetes „körülnézést”, a munkahely keresését. Másfelől viszont korlátozzák, becsatornázzák az egyének választási lehetőségeit (Portes 1995; Guilmoto \& Sandron 2001; Sassen 1995), úgynevezett migráns „,tömbök” kialakulásához vezetve városok és intézmények szintjén. 


\section{KÖVETKEZTETÉSEK}

Az értekezésben alapjául szolgáló kutatás az erdélyi magyar társadalom egy sajátos alnépességének, az egészségügyi dolgozóknak a Magyarországra irányuló vándorlására irányult.

A rendelkezésre álló statisztikai adatok elemzése alapján megállapítható, hogy a Magyarországon egészségügyi diplomát honosítottak száma a rendszerváltást követő két évtizedben követte az általános trendet: az erdélyi bevándorlók számának időbeli változásait. Két csúcspont figyelhető meg ebben az időszakban: az első a rendszerváltozás és az azt közvetlenül követő két-három év, a másik pedig a Magyarország uniós tagállammá válását követő esztendő. Románia EU-s csatlakozása és a nem sokkal később beköszöntő gazdasági válság eredményeképpen Magyarország veszít vonzerejéből az egészségügyi dolgozók számára is (Gödri \& Kiss 2009; Ábrám 2011), az anyaországba vándorlók száma hirtelen lecsökken.

De az interjúk tanúsága szerint Magyarország egy tranzitország szerepét töltötte be már korábban is némely itt dolgozó és élő orvos és szakdolgozó számára. Az etnikai tőkének (nyelvi-kulturális kapcsolatok), korábbi személyes migrációs tapasztalatoknak és kiterjedt migráns hálózatoknak, valamint intézményileg szervezett vagy személyes toborzási tevékenységeknek köszönhetően döntött a pályakezdő orvosok és nővérek egy része az anyaországban való munkavállalás mellett. A megváltozott referenciatér, új ismeretek és a relatív depriváció következtében viszont többen is a továbbvándorlást fontolgatják. A már itt praktizáló, ugyanakkor sodródó léthelyzetben levő orvosok és nővérek közül azokat tudja „megtartani” Magyarország, akik számára fontos a magyar nyelvi és kulturális környezet, illetve a hátrahagyott szülőföldhöz való viszonylag kis földrajzi távolság, a kapcsolattartás a kibocsátó közösséggel (család, barátok).

A vizsgált magyar nyelvü csoport körében magas a migrációs hajlandóság az erdélyi magyar felnőtt népességéhez képest: a diákoknak több mint fele tervezi a külföldi munkavállalást, vagy friss diplomásként vagy néhány éves tapasztalatszerzés után. Ezt részben magyarázza a magas iskolai végzettség és a fiatal életkor, ami jellemzi őket; hiszen az erdélyi magyar fiatalok és a magyarországi rezidens orvosok körében a migrációs potenciál mértéke hasonló (NKI 2013; Eke et al. 2011).

A migráció tervezésének esélyét leginkább a kilátástalannak ítélt - rövid távú jövő és a célországgal összekötő migráns kapcsolatok növelik (Sik \& Örkény 2003; Kiss \& Csata 2004; Gödri 2010), illetve nagyobb eséllyel tervezik a külföldi 
munkavállalást az „aktív” nyelvtudással rendelkező hallgatók, akik gyakran fogyasztanak idegen nyelvü médiát. A jövőről alkotott pesszimista kép nem(csak) egy magyar, a kisebbségi léthelyzetből fakadó sajátosság, hanem a többségi társadalom tagjaira is általánosan jellemző, erősítve vagy legitimizálva a migráció tervét. A migráns hálózat és a humán tőke hatása a tisztított migrációs potenciál esetében is megmutatkozik, illetve az attitűdváltozók közül a pályakezdő fizetések szűkösségétől való félelem az, amely leginkább a külföldi munkavállalásra serkenti a majdani egészségügyi dolgozókat. A fejlettebb országok részéről jelentkező húzó tényezők közül pedig a jobb szakmai fejlődés lehetősége növeli szignifikánsan az esélyét annak, hogy a migrációt tervező már tett is valamit annak érdekében, hogy szándékát megvalósítsa.

Az elégedetlenség érzése csakugyan növeli a külföldi munkavállalás tervezésének esélyét (Sik \& Örkény 2003). A képzéssel való elégedetlenség hátterében gyakran egy korábbi szakmai migrációs tapasztalatból származó relatív depriváció áll. Elmondható tehát, hogy a különböző nemzetközi, hallgatói mobilitást szorgalmazó és támogató ösztöndíj programok az elsődlegesen kitüzött cél - a szakmai innováció vagy „brain circulation” - megvalósítása mellett egy másodlagos hatást is kifejtenek: a szakmai relatív depriváció megszületését vagy erősödését (Knight 2014; Hawthorne 2012). A szakmai deprivációt kiválthatja továbbá a nyugati rendszer szerint történő oktatás és az elsajátított tudás megvalósításának tárgyi feltételeit nem biztosító egészségügyi rendszer közötti diszharmónia (Portes \& Böröcz 2001); illetve a migráns hálózatokon keresztül áramló információk is (Sassen 1995).

A migráns hálózatok szerepe régóta kulcsfontosságú a migrációs kutatásokban, illetve az erdélyi bevándorlók esetében is gyakran elemzés tárgyát képezte. Jelen esetben is bebizonyosodott az, hogy a magyar tannyelvü hallgatók számára az elsődleges információforrás szerepét is betöltik, megkönnyítve és előkészítve a külföldi munkavállalást. Érdekes eredménye a kutatásnak a két nemzetiségü csoport migrációs hálózata különbözőségének és ebből eredően eltérő hatásának feltárása. ${ }^{244}$ A magyar nyelvü csoport baráti migráns kapcsolatai zömében a kibocsátó közösségbe ágyazottak (Tilly 2001), és többnyire kollegiális hálózatot jelentenek. Így inkább erősítik a migrációs terveket, mint a román tannyelvü hallgatók körében, akiknek baráti migráns hálózataik főként a befogadó társadalom tagjaiból épülnek fel, így valószínúleg „frissebb” kapcsolatok és kisebb mértékü mobilizálható tőkét jelentenek. A baráti migráns hálózatok összetételéhez kapcsolódik, hogy a magyar tannyelvü hallgatók esetében a magasabb fokú - társalgási szintü - idegennyelv-ismeret és a migráció

${ }^{244}$ A kontrollminta alacsony esetszáma miatt viszont tanácsos fenntartással kezelni ezt a megállapítást. Érvényességének megállapításához egy nagyobb, reprezentatív mintán való tesztelése ajánlott. 
tervezése között pozitív kapcsolat létezik, a román nyelvü csoportban - akiknek külföldön élő barátai eltérő nemzetiségüek, tehát a kapcsolat eleve feltételezi az idegennyelv-ismeretet - ez az összefüggés nem áll fenn.

A migráns kapcsolatok becsatornázzák az egyén választási körét a célterületek tekintetében (Portes 1995; Guilmoto \& Sandron 2001; Portes \& Sensenbrenner 2001; Sassen 1995), így a kutatott végzős román és magyar nyelvű csoportok célországaik tekintetében - bár vannak közös metszéspontok - a korábbi migrációs potenciál kutatások által megállapított országokat részesítik előnyben. Tehát az anyagi (magasabb bérek) motiváción túl fontos szerepet kapnak a nyelvi-kulturális hasonlóságok, a már korábban kialakult, történelmi kapcsolatok az adott országokkal (Portes \& Böröcz 1989). Illetve a hálózatok információkat közvetítő szerepe is kifejti hatását (Hárs 1992a), hiszen minden gyüjtött információ a kapcsolatok adott térbeli eloszlása és azon időszak alapján mintázott, amikor a kapcsolatok léteznek; tehát a továbbított információk nem általánosak, hanem helyhez kötöttek (Sassen 1995). Jóllehet a kapcsolati tőke-szegények migrációs készsége megközelíti azokét, akik rendelkeznek migráns kapcsolattal a kiválasztott célország(ok)ban, az előbbiek terve kisebb eséllyel valósul meg.

Favell és munkatársainak a „brain circulation” elmélet kapcsán tett kritikáját vagyis az elmélet alapjául szolgáló feltételezés korlátozottságát - támasztják alá a narratív interjúk. A fejlettebb országokban megszerzett technikai tudásfölény nem a hazavándorlás szándékát segíti, inkább elriasztja a migránst a visszatéréstől, mivel szakmai visszalépésként értékeli azt (Favell et al. 2008).

Az erdélyi magyar nyelvü egészségügyi képzés végzősei számára (potenciális migránsok) Magyarország kevésbé jön számításba célországként, mint a - bérek szempontjából - nagyobb komparatív előnyöket kínáló Németország vagy Anglia. A nyugati, fejlettebb országokba kiépült migráns hálózatok müködése mellett Magyarországnak a még fennálló vonzereje elsősorban a román képzési rendszertől való eltérő müködésének (pl. több szakosodási lehetőség) és az általa nyújtott jobb munkakörülményeknek tulajdonítható.

A román nyelvismeret szintje nem gyakorol szelekciós hatást a célterület megválasztására, szemben a korábbi kutatások eredményeivel (Gödri \& Kiss 2009). Tehát a hiányos román nyelvismeret nem feltétlenül Magyarország irányába tereli a potenciális migránsokat; legalább akkora körükben a Nyugat-Európába igyekvők aránya, mint az anyaországba. Viszont a hallgatói népesség eleve szelektált jellege is szerepet játszhat benne. 
A társadalmi státus nem tematizálódott a már átvándoroltak migrációs narratíváiban, viszont látható, hogy befolyásolja a migrációs potenciált. Bár mind a magas, mind az alacsony társadalmi státusú családból származó hallgatók nagyobb eséllyel tervezik a külföldi munkavállalást a vegyes státusúakhoz képest, a migrációs tervek előkészítésében és megvalósításában fontos az, hogy a migráns hálózatok, amelyeknek tagjaik, hol helyezkednek el a társadalmi struktúrában. A hallgatókkal készült interjúk megerősítik Portes társadalmi tőke kapcsán tett megállapítását, miszerint a társadalmi struktúrában elfoglalt hely meghatározza az egyén társai által birtokolt erőforrásokat, amelyekhez az egyén tagsága révén hozzájuthat (Portes 1998). Egy másik lényeges tényező a szándék megvalósításához szükséges anyagi tőke megléte. A gazdasági tőke hiánya különböző attitüdökhöz vezet a migrációt komolyan fontolgatók esetében. Némely esetben egyfajta álomképpé alakítja a migrációt, amelyben a külföldi munkavállalás nagyszerü kaland lenne a fiatal, friss diplomásnak, viszont egyelőre csak azt a feszültséget éli meg, amely a vágyai és lehetőségei között feszül (de Haas 2011). Egy másik típus, aki nélkülözi a külföldi munkavállaláshoz szükséges anyagi fedezetet az, akinek szándékát megerősíti a kitörni vágyás a „kinti jobb élet” reményében. És van egy harmadik attitüd is, az elfogadóé, aki családja, a szülöföldhöz való ragaszkodása, valamint a kisebbségben élő magyarság iránt érzett és vállalt felelősségére hivatkozva dönt a helyben maradás mellett.

A kutatás egy további fontos következtetése, hogy a döntési mechanizmusokban - a hallgatókéban és a migránsokéban egyarán - nagy szerepet kapnak a globális hierarchiák (Portes 1995), az országok relatív pozíciója, amelyekre elsősorban a bérkülönbségek és az egészségügyi intézmények felszereltsége közötti eltérések, a Nyugat-Kelet ellentétpár gyakori említése révén reflektálnak (Melegh 2012).

A külföldön megszerezhető magasabb bérek valamennyi társadalmi státusú csoportot motiválnak a migrációra, de míg a vizsgálati csoportban a gazdasági tőke növelése elsősorban a státusmegőrzést szolgálja (legnagyobb arányban a magas és a vegyes státusúak számára motiváció), addig a referencia csoportban inkább a felfelé mobilitás eszközévé válik (vegyes és alacsony státusúak említették nagyobb arányban). ${ }^{245} \mathrm{Ez}$ utóbbi összefüggést erősíti az is, hogy a román hallgatók számára nagyobb húzó hatást jelent a nyugati országok által nyújtott magasabb életszínvonal.

Egy migrációs kultúra (Massey et al. 1994) jelenléte figyelhető meg a migránsok és a diákok körében. A hallgatók is kiterjedt ismerettel rendelkeznek - elsősorban

\footnotetext{
${ }^{245}$ Ez a nővéri alminta kihagyása esetében érvényes összefüggés. Ha az asszisztenseket is tekintetbe vesszük, akkor a magyar hallgatók körében is érvényessé válik a referencia csoport kapcsán tett megállapítás.
} 
kollegiális migráns hálózataik révén - a különböző országokban elérhető komparatív előnyökről, amelyek elősegíthetik a relatív depriváció megszületését vagy elmélyülését. A migráció mint életstratégia teljesen nyitott - sőt bátorított, majdhogynem előírt választási lehetőségként áll előttük, amellyel kapcsolatosan meg kell hozniuk saját döntésüket.

A külföldi munkavállaláshoz pozitív értékek is társulnak, mint például a bátorság, de sokan azt vallják, hogy a többszörösen magasabb bérért végzett külföldi munka a „könnyebb út” választása, amely egyben a „modern rabszolgaság”, az otthonhoz füződő kapcsolatok elszakításával járó sodródó élethelyzet.

Mindezek alapján megállapítható, hogy a migráció - ahogyan az új közgazdaságtan modellje felismerte (Roberts 1995; Massey 1999) - nem egy kizárólagosan individuális döntés eredménye. Az egyéni mérlegelés beleilleszkedik a családi, párkapcsolati viszonyokba és döntésekbe. A narratív interjúk egy fontos tanulsága, hogy a potenciális migráns számára alapvető kérdés, hogy össze tudja-e egyeztetni migrációs terveit a párkapcsolatával vagy szüleihez való viszonyával. A migrációs potenciál kutatásoknak egy módszertani korlátját jelenti, hogy nem vizsgálják ezeket az összefüggéseket. A bemutatott kutatás megismétlése vagy kiterjesztése esetén a kérdőívbe olyan jellegü kérdéseket is beépítenék, amelyek a potenciális migráns döntésében szerepet játszó egyének befolyását is igyekezne felmérni.

A jövőbeli egészségügyi dolgozókat leginkább a magasabb fizetés biztosításával és a szakmai színvonal javításával tudná helyben tartani a kibocsátó társadalom. Ez utóbbi elsősorban a tárgyi feltételek biztosítását jelenti a román tannyelvű hallgatók esetében - mint a jobb munkakörülmények és felszerelés -, a magyar nyelvü csoport pedig a kollegiális közösség attitüdjének megváltozását igényli: a kezdők nagyobb mértékű megbecsülését és az idős, tapasztalt kollégák támogató hozzáállását.

A kutatás lehetséges további irányai. A migrációs potenciál kérdőíves felmérésének nagyobb mintán való megismétlése a vizsgálati csoport eredményei érvényességének és általánosíthatóságának ellenőrzését segítené, ugyanakkor a nem reprezentatív kontrollcsoport kapcsán tett megállapítások korlátozottságát is feloldaná. Egy további lehetséges folytatás egy panel vizsgálat: a survey és fél-strukturált interjúk által megkérdezett és már hivatásukat gyakorló orvosok, fogorvosok, gyógyszerészek és nővérek újbóli megkeresése a tervezett migráció vagy otthon maradás megvalósulásának mérése végett. Ezt elsősorban az interjúalanyok esetében tartom kivitelezhetőnek - beleértve a narratív interjúkban mesélő migránsokat is, akik esetében a szekunder migráció vagy a visszatérés kerülhetne a kutatás fókuszába. A kutatás kiterjesztésének egy további lehetséges szála a visszavándoroltak vagy a 
Magyarországról Erdélybe ingázó egészségügyi dolgozók motivációinak kutatása lehetne. 


\section{BIBLIOGRÁFIA}

Ábrám, Z., 2011. Az erdélyi magyar orvosmigráció újabb hullámai. Korunk, 22(4), pp.95-100.

Andreescu, D.N., 2005. Alocaţiunea la masa rotundă de CNSLR Frăţia cu tema "Migrația salariatelor din sistemul sanitar- încotro...?" (A Romániai Szabad Szakszervezetek Nemzeti Szövetsége elnökének beszéde “Az egészségügyi rendszer alkalmazottainak migrációja-... felé?" témakörb. Available at: http://www.omfm.ro/dms/detaliu_articol.php?recordID=62.

Babbie, E., 2003. A társadalomtudományi kutatás gyakorlata 9th ed., Budapest: Balassi Kiadó.

Bagchi, A.D., 2001. Migrant networks and the immigrant professional : An analysis of the role of weak ties. Population Research and Policy Review, 20, pp.9-31. Available

at: http://download.springer.com/static/pdf/872/art\%253A10.1023\%252FA\%253A101 0608225985.pdf?auth66=1403685656_2cd36c37b48e444429af725df3883718\&ext $=$.pdf.

Balázs, P., 2003. Migráció a magyar orvostársadalomban és az 1989-es rendszerváltozás hatása. Egészségügyi Gazdasági Szemle, (4), pp.5-12.

Baldwin-Edwards, M., 2008. Migration policies for a Romania within the European Union: Navigating between Scylla and Charybdis. In G. Silași \& O. L. Simina, eds. Migration, Mobility and Human Rights at the Eastern Border of the European Union-Space of Freedom and Security. Timisoara: Editura Universității de Vest, pp. 257-288. Available at: http://papers.ssrn.com/sol3/papers.cfm?abstract_id=1319308.

Balogh, Z., 2009. Tények a szakdolgozók migrációjáról. MESZK, p.3. Available at: http://www.meszk.hu/upload/meszk/document/migracio_felmeres_200909.pdf?we b_id=.

Bauböck, R., 2001. International Migration and Liberal Democracies. The Challenge of Integration. Patterns of Prejudice, 35(4), pp.33-49. Available at: http://dx.doi.org/10.1080/003132201128811278.

Baukó, M. et al., 2003. Humánerőforrás-hiány az egészségügyben- rövid vagy hosszú távú probléma? Egészségügyi Menedzsment, (4), pp.45-51.

Biró, A.Z., 1996. Egyéni és kollektív identitás a kilépés gyakorlatában. In J. Bodó, ed. Elvándorlók? Vendégmunka és életforma a Székelyföldön. Csíkszereda: Pro-Print Könyvkiadó, pp. 123-141.

Black, R. et al., 2006. Migration and Development: Causes and Consequences. In R. Penninx et al., eds. The Dynamics of International Migration and Settlement in Europe. Amsterdam: Amsterdam University Press, pp. 41-64.

Bodó, J., 2008. Diskurzusok és életutak a migráció tükrében, Budapest: Scientia Humana. 
Bose, P.S., 2012. Mapping Movements: Interdisciplinary Approaches to Migration Research. In C. Vargas-Silva, ed. Handbook of Reasearch Methods in Migration. Edward Elgar, pp. 273-294.

Brettel, B.C., 2000. Theorizing Migration in Anthropology. The Social Construction of Networks, Identities, Communities and Globalscapes. In B. C. Brettel \& F. J. Holliefield, eds. Migration Theory. Talking Across Disciplines. Routledge, pp. 97135.

Brubaker, R., 1998. Migration of Ethnic Unmixing in the "New Europe." International Migration Review, 32(4), pp.1047-1065. Available at: http://dx.doi.org/10.2307/2547671.

Brubaker, R. et al., 2006. Nationalist Politics and Everyday Ethnicity in a Transylvanian Town, New York: Princeton University Press.

Bryman, A., 2008. Social research methods 3rd ed., Oxford: Oxford University Press.

Butler, T., 1995. The Debate Over the Middle Classes. In T. Butler \& M. Savage, eds. Social Change and the Middle Classes. London: University College London Press, pp. 26-36.

Castles, S., 2000. International migration at the beginning of the twenty-first century: global trends and issues. International Social Science Journal, 52(165), pp.269281. Available at: http://dx.doi.org/10.1111/1468-2451.00258.

Castles, S., 2004. The Factors that Make and Unmake Migration Policies. International Migration Review, 38(3), pp.852-884. Available at: http://dx.doi.org/10.1111/j.1747-7379.2004.tb00222.x.

Castles, S., 2012. Understanding the Relationship Between Methodology and Methods. In C. Vargas-Silva, ed. Handbook of Reasearch Methods in Migration. Edward Elgar, pp. 7-25.

Castles, S., de Haas, H. \& Miller, M.J., 2014. The Age of Migration 5th ed., London: Palgrave Macmillan.

Castles, S. \& Miller, M.J., 2009. The Age of Migration 4th ed., Palgrave Macmillan.

Cehan, I., 2013. Migraţia medicilor români şi etica recrutării internaţionale (A román orvosok migrációja és a nemzetközi toborzás etikája). Revista Română de Sociologie, 24(3-4), pp.327-335. Available at: http://www.revistadesociologie.ro/pdf-uri/nr.3-4-2013/19-ICehan.pdf.

Cehan, I. \& Teodorescu, C., 2012. Migrația personalului medical între responsabilitate socială și dreptul la liberă circulație (Az orvosi személyzet migrációja a társadalmi felelösség és a szabad mozgáshoz való jog között). Revista Română de Bioetică, 10(4), pp.35-43. Available at: www.bioetica.ro/index.php/arhivabioetica/article/.../415.

Coggi, P.T., 2011. Foreword. In M. Wismar et al., eds. Health Professional Mobility and Health Systems. WHO, p. ix. 
Coleman, D.A., 2006. Mass Migration to Europe: Demographic Salvation, Essential Labor, or Unwanted Foreigners? In A. M. Messina \& G. Lahav, eds. The Migration Reader. Exploring Politics and Policies. London: Lynne Rienner Publishers, pp. 348-371.

Constantin, D.L. et al., 2004. Fenomenul migraționist din perspectiva aderării României la Uniunea Europeană (A migráció jelensége Romániának az Európai Unióhoz való csatlakozásának perspektivájából), Bucuresti.

Conway, D., 2000. Notions Unbounded: A Critical (Re)read of Transnationalism Suggests that U.S.-Carribean Circuits Tell the Story Better. In B. Agozino, ed. Theoretical and Methodological Issues in Migration Research. Interdisciplinarity, Intergenerational and International Pesrpectives. Aldershot: Ashgate, pp. 203226.

Cseresnyés, F., 1991. Migrációs tendenciák Magyarországon az 1990-es években. Belügyi Szemle, (1), pp.35-49.

Demuth, A., 2000. Some Conceptual Thoughts on Migration Research. In B. Agozino, ed. Theoretical and Methodological Issues in Migration Research. Interdisciplinarity, Intergenerational and International Pesrpectives. Ashgate, pp. 21-58.

DPR, 2013. Hallgatók 2012. Kutatási zárótanulmány, Budapest. Available at: http://www.felvi.hu/pub_bin/dload/Hallgatok_2012_zarotanulmany.pdf.

Eke, E., Girasek, E. \& Szócska, M., 2011. From Melting Pot to Laboratory of Change in Central Europe: Hungary and Health Workforce Migration. In M. Wismar et al., eds. Health Professional Mobility and Health Systems. WHO, pp. 365-394.

Eke, J., Girasek, E. \& Szócska, M., 2009. A migráció a magyar orvosok körében. Statisztikai Szemle, (7-8), pp.795-827.

EMK, 2012. Az egészségügyi emberi eröforrásai. Felmérés a rezidens orvosok migrációs szándékairól, pályaválsztási terveikről és azok motivációs erőteréről2012 Budapest. Available at: http://semmelweis.hu/emk/files/2007/11/2012rezidens_eredmenyek.pdf.

Faist, T., 2000. Transnationalization in International Migration: Implications for the Study of Citizenship and Culture. Ethnic and Racial Studies, 23(2), pp.189-222. Available at: http://dx.doi.org/10.1080/014198700329024.

Fakhri, S.M.A.K., Willis, K.D. \& Yeoh, B.S.A., 2003. Transnational Edges. Ethnic and Racial Studies, 26(2), pp.207-217.

Favell, A., Feldblum, M. \& Smith, M.P., 2008. The Human Face of Global Mobility: A Research Agenda. In M. P. Smith \& A. Favell, eds. The Human Face of Global Mobility: International Highly Skilled Migration in Europe, North America and the Asia-Pacific. Transaction Publishers, pp. 1-25.

Fawcett, J.T., 1989. Networks, Linkages, and Migration Systems. International Migration Review, 23(3), pp.671-680. Available at: http://dx.doi.org/10.2307/2546434. 
Feischmidt, M. \& Zakariás, I., 2010. Hazatérő idegenek. Az etnikai migráció formái, okai és hatásai a Kárpát-medencében. In Á. Hárs \& J. Tóth, eds. Változó migrációváltozó környezet. Budapest: MTA Etnikai-nemzeti Kisebbségkutató Intézet, pp. 59-86.

Feliciano, C., 2005. Does Selective Migration Matter? Explaining Ethnic Disparities in Educational Attainment among Immigrants' Children. International Migration Review, 39(4), pp.841-871. Available at: http://dx.doi.org/10.1111/j.17477379.2005.tb00291.x.

Festinger, L., 2000. A kognitív disszonancia elmélete, Budapest: Osiris.

Fox, J., 2003. National Identities on the Move: Transylvanian Hungarian Labour Migrants in Hungary. Journal of Ethnic and Migration Studies, 29(3), pp.449-466. Available at: http://dx.doi.org/10.1080/13691830305612.

Freidson, E., 1970. Profession of Medicine. A Study of the Sociology of Applied Knowledge, New York: Dodd, Mead \& Company.

Galan, A., Olsavszky, V. \& Vladescu, C., 2011. Emergent Challenge of Health Professional Emigration: Romania's accession to the EU. In M. Wismar et al., eds. Health Professional Mobility and Health Systems. WHO, pp. 449-478.

Gárdos, É. \& Gödri, I., 2014. Analysis of Existing Migratory Data Production Systems and Major Data Sources in Eight South-East European Countries, Budapest. Available http://www.seemig.eu/downloads/outputs/SEEMIGWorkingPapers2.pdf.

Geddes, A., 2011. Overview. In A. Geddes, ed. International Migration. London: Sage Publications, pp. 1-16. Available at: http://dx.doi.org/10.4135/9781446262160.

George, A., 2007. Human resources for health: a gender analysis, Available at: http://www.who.int/social_determinants/resources/human_resources_for_health_w gkn_2007.pdf?ua=1.

Glick Schiller, N., Basch, L. \& Szanton Blanc, C., 1995. From Immigrant to Transmigrant: Theorizing Transnational Migration. Anthropological Quarterly of UNH, 68(1), pp.48-63. Available at: http://dx.doi.org/10.2307/3317464.

Glinos, I.A. et al., 2011. Health professional mobility and health systems in Europe: 67 conclusions from the case-studies. In M. Wismar et al., eds. Health Professional Mobility and Health Systems. Copenhagen: WHO, pp. 67-86.

Goldthorpe, J., 1982. On the Service Class, Its Formation and Future. In A. Giddens \& G. Mackenzie, eds. Social Class and the Division of Labour. Cambridge: Cambridge University Press, pp. 162-185.

Gödri, I., 1998. A romániai magyar értelmiségiek kivándorlásának motivációs háttere és ideológiai vonatkozásai. Regio. Kisebbség, politika, társadalom, 9(3), pp.75-99. Available at: http://epa.oszk.hu/00000/00036/00033/pdf/05.pdf. 
Gödri, I., 2010. Bevándorlás és etnicitás- összefüggések nyomában. In Á. Hárs \& J. Tóth, eds. Változó migráció- változó környezet. Budapest: MTA Etnikai-nemzeti Kisebbségkutató Intézet, pp. 87-124.

Gödri, I., 2004. Etnikai vagy gazdasági migráció? Az erdélyi magyarok kivándorlását meghatározó tényezők az ezredfordulón. Erdélyi Társadalom, (1), pp.37-54.

Gödri, I., 2005. Nők és férfiak a migrációs folyamat különböző szakaszaiban. In I. Nagy, T. Pongrácz, \& I. G. Tóth, eds. Szerepváltozások. Jelentés a nök és a férfiak helyzetéröl. Budapest: TÁRKI, pp. 149-164.

Gödri, I. \& Kiss, T., 2009. Migrációs hajlandóság, tervek és attitüdök az erdélyi magyarok körében. In Z. Spéder, ed. Kutatásjelentések 86. Párhuzamok. Anyaországi és erdélyi magyarok a századfordulón. Budapest: KSH Népességtudományi Kutatóintézet, pp. 183-215.

Gödri, I. \& Tóth, P.P., 2005. Bevándorlás és beilleszkedés. A szomszédos országokból Magyarországra irányuló bevándorlás az ezredfordulón., Budapest.

Granovetter, M.S., 2010. A gyenge kötések ereje. A hálózatelmélet felülvizsgálata. In R. Angelusz, M. Éber, \& O. Gecser, eds. Társadalmi rétegzödés olvasókönyv. TÁMOP 2010-201, pp. 315-329. Available at: http://www.tankonyvtar.hu/hu/tartalom/tamop425/0010_2A_19_Tarsadalmi_reteg zodes_olvasokonyv_szerk_Gecser_Otto/ch06s03.html.

Greco, G., 2010. International Migration of Health Professionals: Towards a Multidimensional Framework for Analysis and Policy Response. In R. S. Shah, ed. The International Migration of Health Workers: Ethics, Rights ans Justice. New York: Palgrave Macmillan, pp. 9-24.

Guilmoto, C.Z. \& Sandron, F., 2001. The Internal Dynamics of Migration Networks in Developing Countries. Population: An English Selection, 13(2), pp.135-164.

De Haas, H., 2011. The Determinants of International Migration, Oxford.

Hárs, Á., 1992a. A nemzetközi migráció néhány problémájáról. Szakirodalmi áttekintés. Szociológiai Szemle, (2), pp.123-137. Available at: http://www.szociologia.hu/dynamic/9202hars.htm.

Hárs, Á., 1992b. Migráció és munkaerőpiac. In E. Sik, ed. Menekülők, vándorlók, szerencsét próbálók. Budapest: MTA Politikatudományok Intézete, pp. 9-21.

Hárs, Á., 2010. Migráció és munkaerőpiac Magyarországon. Tények, okok, lehetőségek. In Á. Hárs \& J. Tóth, eds. Változó migráció- változó környezet. Budapest: MTA Etnikai-nemzeti Kisebbségkutató Intézet, pp. 15-53.

Hawthorne, L., 2012. Designer Immigrants 1?: International Students and Two-Step Migration. In D. K. Deardorff et al., eds. The SAGE Handbook of International Higher Education. Thousand Oaks: Sage Publications, pp. 417-436. Available at: http://dx.doi.org/10.4135/9781452218397.n23. 
Hirschman, A.O., 2001. Kivonulás, tiltakozás és a Német Demikratikus Köztársaság sorsa: egy elmélettörténeti esszé. In E. Sik, ed. A migráció szociológiája. Budapest: Szociális és Családügyi Minisztérium, pp. 213-234.

Horváth, I., 2002. A romániai magyar kisebbség Magyarországra irányuló mozgása. Korunk,

Available

at: http://www.korunk.org/?q=node/8\&ev=2002\&honap=2\&cikk=6812 [Accessed March 15, 2014].

Horváth, I., 2003a. A vendégmunka. Korunk, (6).

Horváth, I., 2003b. Migrációs hajlandóság az erdélyi magyarság körében- 2003 október. Erdélyi Társadalom, (2), pp.39-54.

Huisman, J. et al., 2012. Europe' s Bologna Process and Its Impact on Global Higher Education. In E. D. K. Deardorff et al., eds. The SAGE Handbook of International Higher Education. Thousand Oaks: Sage Publications, pp. 81-100. Available at: http://dx.doi.org/10.4135/9781452218397.n5.

Ion, C., 2006. Reperfuzia sistemului medical (Az orvosi rendszer feltöltése). Available at:

http://www.presspromedic.ro/index.php?option=com_content\&task=view\&id=125 $\&$ Itemid $=165$.

Jakab, Z., 2011. Foreword. In M. Wismar et al., eds. Health Professional Mobility and Health Systems. WHO, p. xi.

Jenkins, R. et al., 2010. International migration of doctors, and its impact on availability of psychiatrists in low and middle income countries. PloS one, 5(2), p.e9049. Available at: http://dx.doi.org/10.1371/journal.pone.0009049 [Accessed March 15, 2014].

Juss, S.S., 2007. International Migration and Global Justice, Ashgate.

Kaelin, L., 2011. Care drain: the political making of health worker migration. Journal of Public Health Policy, 32(4), pp.489-98. Available at: http://dx.doi.org/10.1057/jphp.2011.43 [Accessed March 15, 2014].

Kandel, W. \& Massey, D.S., 2002. The Culture of Mexican Migration: A Theoretical and Empirical Analysis. Social Forces, 80(3), pp.981-1004. Available at: http://dx.doi.org/10.1353/sof.2002.0009.

Kearney, M., 2004. Introduction: Migration and Identities: A Class-Based Approach. Latin American Perspectives, 31(5), pp.3-14. Available at: http://lap.sagepub.com/cgi/doi/10.1177/0094582X04268399 [Accessed September 27, 2014].

Kincses, Á., 2010. A Kárpát-medence országaiból Magyarországra tartó vándorlások demográfiai és geográfiai vonatkozásai, 2001-2008. Demográfia, 53(2-3), pp.205233. Available at: http://www.demografia.hu/letoltes/kiadvanyok/Demografia/2010_23/3_Kincses_tan.pdf. 
Kiss, T., 2012. Demográfiai körkép. A kisebbségi magyar közösségek demográfiai helyzete a Kárpát-medencében. Educatio, 21(1), pp.24-48.

Kiss, T., Barna, G. \& Sólyom, Z., 2008. Erdélyi magyar fiatalok 2008. Közvéleménykutatás az erdélyi magyar fiatalok társadalmi helyzetérōl és elvárásairól. Összehasonlitó gyorsjelentés, Kolozsvár. Available at: http://www.ispmn.gov.ro/uploads/Kiss-Barna-Solyom-12.pdf.

Kiss, T. \& Csata, Z., 2004. Migrációs-potenciál vizsgálatok Erdélyben. In T. Kiss, ed. Népesedési folyamatok az ezredfordulón Erdélyben. Kolozsvár: Kriterion, pp. 91122.

Kisvarga, Z., 2005. Az orvoslétszám tervezhetőségének problémái. Magyar Rezidens Szövetség. Available http://www.rezidens.hu/index.php?c=view\&type=news\&id=410.

Kivisto, P., 2001. Theorizing Transnational Immigration: A Critical Review of Current Efforts. Ethnic and Racial Studies, 24(549-577). Available at: http://dx.doi.org/10.1080/01419870120049789.

Knight, J., 2014. Concepts, Rationales, and Interpretive Frameworks in the Internationalization of Higher Education. In D. K. Deardorff et al., eds. The SAGE Handbook of International Higher Education. Thousand Oaks: Sage Publications, pp. 27-42. Available at: http://dx.doi.org/10.4135/9781452218397.n2.

Kolosi, T. \& Keller, T., 2012. Megéri tanulni?... Származás, iskola, foglalkozás, kereset- utak és elágazások a rendszerváltást követően. In T. Kolosi \& I. G. Tóth, eds. Társadalmi Riport 2012. Budapest: TÁRKI, pp. 41-46.

Koltai, J. \& Sik, E., 2012. Határokon átnyúló munkaerő-piaci és jövedelemszerző mozgások a "végeken." In T. Kolosi \& I. G. Tóth, eds. Társadalmi Riport 2012. Budapest: TÁRKI, pp. 209-226.

Kovács, É. \& Melegh, A., 2004. A vándorlást elbeszélő narratívák neme, avagy a nők és férfiak elbeszélései- női és férfi elbeszélésmódok. In A. Pető, ed. Társadalmi nemek képe és emlékezete Magyarországon a 19-20. században. A Nők a Valódi Esélyegyenlöségért Alapítvány, pp. 175-195.

Kovács, É. \& Melegh, A., 2007. In a Gendered Space. Demográfia, 50(5), pp.26-59.

Kovács, É. \& Melegh, A., 2001. "It could have been worse: we could have gone to America". Migration Narratives in the Transylvania-Hungary-Austria Triangle. In P. Nyíri, J. Tóth, \& M. Fullerton, eds. Diasporas and Politics. Budapest: MTA Politikatudományok Intézete, pp. 108-135.

Lahav, G. \& Lavenex, S., 2013. International Migration. In W. Carlsnaes, T. Risse, \& Beth A. Simmons, eds. Handbook of International Relations. London: Sage Publications, pp. 746-775. Available at: http://dx.doi.org/10.4135/9781446247587.n30.

Lavenex, S., 2008. The competition State and Multilateral Liberalization of Highly Skilled Migration. In M. P. Smith \& A. Favell, eds. The Human Face of Global 
Mobility: International Highly Skilled Migration in Europe, North America and the Asia-Pacific. New Brunswick: Transaction Publishers, pp. 29-52.

Levatino, A. \& Pecoud, A., 2012. Overcoming the Ethical Dilemmas of Skilled Migration? An Analysis of International Narratives on the "Brain Drain." American Behavioral Scientist, 56(9), pp.1258-1276. Available at: http://dx.doi.org/10.1177/0002764212443817 [Accessed March 15, 2014].

Levitt, P. \& de la Dehesa, R., 2003. Transnational Migration and the Redefinition of the State: Variations and Explanations. Ethnic and Racial Studies, 26(4), pp.587-611. Available at: http://dx.doi.org/10.1080/0141987032000087325.

Macovei, V., 2004. Unde veți putea lucra în Europa (Hol dolgozhatnak majd Európában). Evenimentul Zilei. Available at: www.evenimentulzilei.ro.

Maier, C.B. et al., 2011. Cross-country Analysis of Health Professional Mobility in Europe: The Results. In M. Wismar et al., eds. Health Professional Mobility and Health Systems. WHO, pp. 23-66.

Massey, D.S. et al., 1993. Theories of International Migration: A Review and Appraisal. Population and Development Review, 19(3), pp.431-466. Available at: http://doi.org/fpbvf4.

Massey, D.S., 1999. Why Does Immigration Occur? A Theoretical Synthesis. In C. Hirschman, P. Kasinitz, \& J. Dewind, eds. The Handbook of International Migration. Russel Sage Foundation, pp. 34-52.

Massey, D.S., Goldring, L. \& Durand, J., 1994. Continuities in Transnational Migration: An Analysis of Nineteen Mexican Communities. The American Journal of Sociology, 99(6), pp.1492-1533.

Mckenzie, D. \& Rapoport, H., 2006. Network effects and the dynamics of migration and inequality: Theory and evidence from Mexico, Available at: http://siteresources.worldbank.org/DEC/Resources/Network_effects_and_the_dyna mics_of.pdf.

Melegh, A., 2011. A globalizáció és migráció Magyarországon. Educatio, (2), pp.166180.

Melegh, A., 2004. Munkások vagy migránsok? Eszmélet, 62(2). Available at: http://www.eszmelet.hu/index2.php?act=period\&lang=HU\&item=163\&auth=Mele gh Attila: \&info=Eszmélet folyóirat, 62. szám (2004. nyár).

Melegh, A., 2012. Net Migration and Historical Development in Southeastern Europe since 1950. Hungarian Historical Review, 1(3-4), pp.415-453. Available at: http://www.seemig.eu/downloads/outputs/HungarianHistoricalReviewMelegh.pdf.

Melegh, A., Kovács, É. \& Gödri, I., 2010. “Azt hittem, célt tévesztettem”. A bevándorló nők élettörténeti perspektívái, integrációja és a bevándorlókkal kapcsolatos attitüdök nyolc európai országban, Budapest: KSH Népességtudományi Kutatóintézet. 
Messina, A.M. \& Lahav, G., 2006. The Migration Reader. Exploring Politics and Policies A. M. Messina \& G. Lahav, eds., London: Lynne Rienner Publishers.

Morris, L., 1997. Globalization, Migration and the Nation-State: The Path to a PostNational Europe? The British Journal of Sociology, 48(2), pp.192-209. Available at: http://dx.doi.org/10.2307/591748.

Nagy, Ö., 2005. Orvosi és Gyógyszerészeti Szemle, MOGYE. Revista de Medicină și Farmacie, UMF, 51, pp.1-161.

Németh, N., Csite, A. \& Jakobi, Á., 2011. Employees with Romanian Citizenship in Hungary. Regional Statistics, 14(Special number), pp.55-63.

Niessen, J., 2000. Diversity and Cohesion: New Challenges for the Integration of Immigrants and Minorities,

NKI, 2013. Erdélyi magyarok a romániai és a magyarországi politikai térben, Kolozsvár.

OECD Statistics, 2014. Average annual wages. Available at: http://stats.oecd.org [Accessed November 20, 2014].

Oliver, C. \& O'Reilly, K., 2010. A Bourdieusian Analysis of Class and Migration: Habitus and the Individualising Process. Sociology, 44(1), pp.49-66. Available at: http://dx.doi.org/10.1177/0038038509351627.

Orbán, A., 2006. A társadalmi tőke koncepciója. In Z. Szántó, ed. Analitikus szemléletmódok a modern társadalomtudományban. Helikon, pp. 137-152.

Orosz, I. \& Molnár, E., 2008. Karrierutak vagy parkolópályák? Friss diplomások karrierje, migrációs tendenciája, felnőttképzési igényei Kárpátalján. Educatio, (1), pp.143-158. Available at: http://epa.oszk.hu/01500/01551/00043/pdf/525.pdf.

Örkény, A., 2003. A migrációs potenciál szociodemográfiai okai a Kárpát-medencei magyarok körében. In A. Örkény, ed. Menni vagy maradni? Kedvezménytörvény és migrációs várakozások. Budapest: MTA Politikatudományok Intézete, pp. 150187.

Packer, C., Runnels, V. \& Labonté, R., 2010. Does the Migration of Health Workers Bring Benefits to the Countries They Leave Behind? In R. S. Shah, ed. The International Migration of Health Workers: Ethics, Rights ans Justice. New York: Palgrave Macmillan, pp. 44-61.

Papp, Z.A. \& Csata, Z., 2013. Aranymetszés 2013. Külhoni magyar doktoranduszok a Kárpát-medencében. Összegzö kutatási jelentés, Budapest. Available at: http://mta.hu/data/cikk/13/18/48/cikk_131848/352_palyamunka_(1).pdf.

Penninx, R., Berger, M. \& Kraal, K., 2006. The Dynamics of International Migration and Settlement in Europe, Amsterdam.

Portes, A., 1999. Conclusion: Towards a New World- The Origins and Effects of Transnational Activities. Ethnic and Racial Studies, 22(2), pp.463-477. Available at: http://dx.doi.org/10.1080/014198799329567. 
Portes, A., 1995. Economic Sociology and the Sociology of Immigration: A Conceptual Overview. In A. Portes, ed. The Economic Sociology of Immigration. Essays on Networks, Ethnicity, and Enterpreneurship. New York: Russel Sage Foundation, pp. 1-41.

Portes, A., 1996. Global Villagers. The Rise of Transnational Communities. The American Prospect, pp.74-77. Available at: http://prospect.org/article/globalvillagers-rise-transnational-communities.

Portes, A., 2008. Migration and Social Change: Some Conceptual Reflections, Available at: https://www.princeton.edu/cmd/working-papers/papers/wp0804.pdf.

Portes, A., 1998. Social Capital: Its Origins and Applications in Modern Sociology. Annual Review of Sociology, 24(1), pp.1-24. Available at: http://dx.doi.org/10.1146/annurev.soc.24.1.1.

Portes, A. \& Böröcz, J., 1989. Contemporary Immigration: Theoretical Perspectives on Its Determinants and Modes of Incorporation. International Migration Review, 23(3), pp.606-626. Available at: http://dx.doi.org/10.2307/2546431.

Portes, A. \& Böröcz, J., 2001. Keserü kenyér: a munkaerő nemzetközi migrációjának szociológiai problémái. In E. Sik, ed. A migráció szociológiája. Budapest: Szociális és Családügyi Minisztérium, pp. 69-87.

Portes, A., Guarnizo, L.E. \& Landolt, P., 1999. The Study of Transnationalism: Pitfalls and Promise of an Emergent Research Field. Ethnic and Racial Studies, 22(2), pp.217-237. Available at: http://dx.doi.org/10.1080/014198799329468.

Portes, A. \& Sensenbrenner, J., 2001. Beágyazottság és bevándorlás: megjegyzések a gazdasági cselekvés társadalmi meghatározóiról. In E. Sik, ed. A migráció szociológiája. Budapest: Szociális és Családügyi Minisztérium, pp. 105-126.

Pries, L., 2003. The Challenge and Chance of Transnational Migration in the New Europe. In Past, Present and Future of European East-West Migrations: Old Predicaments and New Challenges. pp. 1-20.

Prónai, C., 2003. Migráció és kulturális antropológia (tudománytörténeti vázlat). Available at: www.mtaki.hu/tanulmanyok/pronai_csaba/migracio_es_kulturalis antropologia.doc.

Recchi, E., 2008. From Migrants to Movers: Citizenship and Mobility in the European Union. In M. P. Smith \& A. Favell, eds. The Human Face of Global Mobility: International Highly Skilled Migration in Europe, North America and the AsiaPacific. Transaction Publishers, pp. 53-77.

Réthy, E., 2002. A kognitív és motivációs önszabályozást kialakító oktatás. Iskolakultúra, (2), pp.3-12. Available at: http://epa.oszk.hu/00000/00011/00057/pdf/tanulm2002-2.pdf.

Riessman, C.K., 2012. Analysis of Personal Narratives. In J. F. Gubrium et al., eds. The Sage Handbook of Interview Research. Sage Publications, pp. 367-379. 
Roberts, B.R., 1995. Socially Expected Durations and the Economic Adjustment of Immigrants. In A. Portes, ed. The Economic Sociology of Immigration. Essays on Networks, Ethnicity, and Enterpreneurship. New York: Russel Sage Foundation, pp. 42-86.

Rohova, M., 2011. Romania. Mobility of Health Professionals. Medical University of Varna, pp.1-292. Available at: http://www.mohprof.eu/LIVE/DATA/National_reports/national_report_Romania.p df.

Román Orvosi Kollégium, 2012. Migratia medicilor- 2012 (Orvosok migrációja). Available at: http://www.opd.ro/CMR/migratia-medicilor-2012/ [Accessed May 1, 2012].

Rosenthal, G., 1993. Reconstruction of Life Stories. The Narrative Study of Lives, (1), pp.59-91.

Saldana, J., 2009. The Coding Manual for Qualitative Research, Sage Publications.

Salt, J., 2001. A nemzetközi tendenciák és típusok összehasonlító áttekintése, 19501980. In E. Sik, ed. A migráció szociológiája. Budapest: Szociális és Családügyi Minisztérium, pp. 59-68.

Sandu, D., 2000a. Migrația circulatorie ca strategie de viață (A cirkuláris migráció mint életstratégia). Sociologie Românească, (2), pp.5-29.

Sandu, D., 2000b. Migrația transnațională a românilor din perspectiva unui recensământ comunitar. Sociologie Românească, (3-4), pp.5-50.

Sassen, S., 2006. Foreign investment: A neglected variable. In A. M. Messina \& G. Lahav, eds. The Migration Reader. Exploring Politics and Policies. London: Lynne Rienner Publishers, pp. 596-608.

Sassen, S., 1995. Immigration and local labor markets. In A. Portes, ed. The economic sociology of immigration: essays on networks, ethnicity, and entrepreneurship. New York: Russel Sage Foundation, pp. 87-127.

Sassen, S., 2007. Sociology of globalization 1st ed., New York: W. W. Norton.

Savage, M., 1995. Class Analysis and Social Research. In T. Butler \& M. Savage, eds. Social Change and the Middle Classes. London: University College London Press, pp. 15-25.

Scott, S., 2006. The Social Morphology of Skilled Migration: The Case of the British Middle Class in Paris. Journal of Ethnic and Migration Studies, 32(7), pp.11051129. Available at: http://dx.doi.org/10.1080/13691830600821802 [Accessed September 27, 2014].

SEEMIG, 2014. A SEEMIG - Managing Migration in South East Europe transznacionális együttmüködési projekt „Helyzetkép a magyarországi elvándorlásról” címü sajtótájékoztatójának sajtóanyaga, Budapest. Available at: http://seemig.eu/downloads/pressroom/SEEMIGpressmaterialBudapest15October2 014.pdf. 
Shah, R.S., 2010a. Introduction. In R. S. Shah, ed. The International Migration of Health Workers: Ethics, Rights ans Justice. Palgrave Macmillan, pp. 1-8.

Shah, R.S., 2010b. The Right to Health, State Responsability and Global Justice. In R. S. Shah, ed. The International Migration of Health Workers: Ethics, Rights ans Justice. New York: Palgrave Macmillan, pp. 78-102.

Sigler, N., 2010. Global Health, Justice and the Brain Drain: A Trade Union Perspective. In R. S. Shah, ed. The International Migration of Health Workers: Ethics, Rights ans Justice. New York: Palgrave Macmillan, pp. 203-214.

Sik, E., 2011a. A migrációs burok. In E. Sik, ed. A migráció szociológiája 2. Budapest: ELTE TáTK, pp. 115-136. Available at: http://www.tankonyvtar.hu/hu/tartalom/tamop425/0010_2A_15_Sik_Endre_Migra cio_szociologiaja_2_Valogatta_es_szerk_Sik_Endre/index.html.

Sik, E., 2003. A migrációs potenciál kutatásának alapfogalmai. In A. Örkény, ed. Menni vagy maradni? Kedvezménytörvény és migrációs várakozások. Budapest: MTA Politikatudományok Intézete, pp. 15-18.

Sik, E., 2011b. Adalékok a menekültek, a menekülés és a menekültügyi rendszer születésének szociológiai jellemzőihez - Magyarország, 1988-1991. In E. Sik, ed. A migráció szociológiája 2. Budapest: ELTE TáTK, pp. 178-216. Available at: http://www.tankonyvtar.hu/hu/tartalom/tamop425/0010_2A_15_Sik_Endre_Migra cio_szociologiaja_2_Valogatta_es_szerk_Sik_Endre/index.html.

Sik, E., 2011c. Kezdetleges gondolatok a diaszpóra fogalmáról és hevenyészett megfigyelések a diaszpórakoncepció magyar nézőpontból való alkalmazhatóságáról. In E. Sik, ed. A migráció szociológiája 2. Budapest: ELTE TáTK, pp. 93-104. Available at: http://www.tankonyvtar.hu/hu/tartalom/tamop425/0010_2A_15_Sik_Endre_Migra cio_szociologiaja_2_Valogatta_es_szerk_Sik_Endre/index.html.

Sik, E., 1993. Románia emigrációs potenciálja. In E. Sik, ed. Útkeresők. Budapes: MTA Politikatudományok Intézete, pp. 19-22.

Sik, E. \& Örkény, A., 2003. A migrációs potenciál kialakulásának mechanizmusai. In A. Örkény, ed. Menni vagy maradni? Kedvezménytörvény és migrációs várakozások. Budapest: MTA Politikatudományok Intézete, pp. 188-200.

Sik, E. \& Simonovits, B., 2003. A migrációs potenciál mértéke és társadalmi bázisa a Kárpát-medencei magyarok körében. In A. Örkény, ed. Menni vagy maradni? Kedvezménytörvény és migrációs várakozások. Budapest: MTA Politikatudományok Intézete, pp. 43-66.

Simonovits, B., 2003. A migrációs burok hatása a migrációs potenciálra a Kárpátmedencei magyarok körében. In A. Örkény, ed. Menni vagy maradni? Kedvezménytörvény és migrációs várakozások. Budapest: MTA Politikatudományok Intézete, pp. 143-149.

Szakáts, M., 1995. Az Erdélyből áttelepült magyarok társadalmi integrációja. Társadalmi Szemle, 50(5), pp.69-79. 
Szakáts, M.E., 1995. Az Erdélyből áttelepült magyarok otthonképe. In E. Sik \& J. Tóth, eds. Táborlakók, diaszpórák, politikák. Budapest: MTA Politikatudományok Intézete, pp. 91-118.

Tilly, C., 2001. Áthelyeződött hálózatok. In E. Sik, ed. A migráció szociológiája. Budapest: Szociális és Családügyi Minisztérium, pp. 89-103.

Toro-Morn, M.I., 1995. Gender, Class, Family, and Migration: Puerto Rican Women in Chicago. Gender and Society, 9(6), pp.712-726. Available at: http://dx.doi.org/10.1177/089124395009006005.

Tóth, J., 2000. Az elmúlt évtized diaszpórapolitikája. In E. Sik \& J. Tóth, eds. Diskurzusok a vándorlásról. Budapest: MTA Politikatudományok Intézete, pp. 218-251.

Tóth, L., 2012. A kollektív cselekvés és a politikai részvétel előfeltételei: igazságosságérzet, identitás, érzelmek, hatékonyság és beágyazottság. In B. Göncz, G. Lengyel, \& L. Tóth, eds. Bevándorlók a magyar társadalom tükrében. Méltóság, igazságosság és civil integráció. Budapest: Budapesti Corvinus Egyetem, pp. 161-190.

Tóth, P.P., 2004. Egy évtized után. Kisebbségkutatás, 13(4), pp.598-626.

Tóth, P.P., 1994. Magyarország új állampolgárai. In E. Sik \& J. Tóth, eds. Jönnek? Mennek? Maradnak?. Budapest: MTA Politikatudományok Intézete, pp. 85-97.

Tóth, P.P., 2003. Nemzetközi vándorlás- magyar sajátosságok. Demográfia, 46(4), pp.332-341. Available at: http://www.demografia.hu/letoltes/kiadvanyok/Demografia/2003_4/Toth Pal Peter_tan.pdf.

Turner, J.H. \& Bonacich, E., 2001. A közvetítő kisebbségek összefoglaló elmélete felé. In E. Sik, ed. A migráció szociológiája. Budapest: Szociális és Családügyi Minisztérium, pp. 127-140.

UN, 2006. International Migration Report 2002. In A. M. Messina \& G. Lahav, eds. The Migration Reader. Exploring Politics and Policies. London: Lynne Rienner Publishers, pp. 24-30.

United Nations, Department of Economic and Social Affairs, P.D., 2013a. International migrant stock: By destination and origin. Available at: http://www.un.org/en/development/desa/population/migration/data/estimates2/esti matesorigin.shtml [Accessed August 27, 2015].

United Nations, Department of Economic and Social Affairs, P.D., 2013b. International Migration Wallchart, Available at: http://www.un.org/en/development/desa/population/migration/publications/wallcha rt/docs/wallchart2013.pdf [Accessed August 27, 2015].

Vertovec, S., 1999. Conceiving and Researching Transnationalism. Ethnic and Racial Studies, 22(2), pp.447-462. Available at: http://dx.doi.org/10.1080/014198799329558. 
Vertovec, S., 2001. Transnationalism and Identity. Journal of Ethnic and Migration Studies, 27(4), pp.573-583. Available at: http://dx.doi.org/10.1080/13691830120090386.

Vízvári, L., 2003. "Népvándorlás” a 21. században az egészségügyi dolgozók körében. Egészségügyi Gazdasági Szemle, (1-2), pp.38-41.

Wallace, C., Chmouliar, O. \& Sidorenko, E., 2001. Nyugat-Európa keleti határa: mobilitás az ütközőzónában. In E. Sik, ed. A migráció szociológiája. Budapest: Szociális és Családügyi Minisztérium.

WHO, 2014. Global Atlas of the Health Workforce. Available at: http://www.who.int/hrh/statistics/hwfstats/ [Accessed November 20, 2014].

Wiegand, B., 2001. A feketepiaci bünözés etnikai és társadalmi struktúrája. In E. Sik, ed. A migráció szociológiája. Budapest: Szociális és Családügyi Minisztérium, pp. 141-154.

Wismar, M. et al. eds., 2011. Health Professional Mobility and Health Systems,

Witz, A., 1995. Gender and Service-Class Formation. In Tim Butler \& Mike Savage, eds. Social Change and the Middle Classes. London: University College London Press, pp. 41-57.

WorldBank, 2014. World Development Indicators. Available at: http://databank.worldbank.org/data/views/variableselection/selectvariables.aspx?so urce=world-development-indicators [Accessed December 2, 2014].

Wuliji, T., Carter, S. \& Bates, I., 2009. Migration as a Form of Workforce Attrition: A Nine-Country STudy of Pharmacists. Human resources for health, 7, p.32. Available at: http://dx.doi.org/10.1186/1478-4491-7-32 [Accessed September 23, 2014].

Zolberg, A., 2001. Újabb hullámok: migrációelmélet egy változó világban. In E. Sik, ed. A migráció szociológiája. Budapest: Szociális és Családügyi Minisztérium, pp. 41-57. 
1. melléklet: Vizsgálati csoport súlyai

\begin{tabular}{|c|c|c|c|c|c|c|c|}
\hline Intézmény & Szak & Kora & Neme & $\begin{array}{l}\text { Teljes } \\
\text { nép. }\end{array}$ & Minta & $\begin{array}{l}\text { Elméleti } \\
\text { gyakoriság }\end{array}$ & Súly \\
\hline MOGYE & $\begin{array}{l}\text { Általános } \\
\text { orvos } \\
\text { Általános }\end{array}$ & $\begin{array}{l}24 \text { éves vagy } \\
\text { fiatalabb }\end{array}$ & Férfi & 41 & 29 & 30 & 1,034483 \\
\hline MOGYE & orvos & 24 vagy fiatalabb & Nő & 71 & 54 & 52 & 0,962963 \\
\hline MOGYE & $\begin{array}{l}\text { Általános } \\
\text { orvos } \\
\text { Általános }\end{array}$ & $\begin{array}{l}25 \text { éves vagy } \\
\text { idősebb }\end{array}$ & Férfi & 10 & 6 & 7 & 1,166667 \\
\hline MOGYE & orvos & $\begin{array}{l}25 \text { vagy idősebb } \\
\text { Összesen }\end{array}$ & Nö & $\begin{array}{c}16 \\
138 \\
\end{array}$ & $\begin{array}{c}12 \\
101 \\
\end{array}$ & $\begin{array}{c}12 \\
101 \\
\end{array}$ & $\begin{array}{l}1 \\
1 \\
\end{array}$ \\
\hline MOGYE & Fogorvos & 24 vagy fiatalabb & Férfi & 6 & 3 & 4 & 1,333333 \\
\hline MOGYE & Fogorvos & 24 vagy fiatalabb & Nő & 30 & 24 & 22 & 0,916667 \\
\hline MOGYE & Fogorvos & 25 vagy idősebb & Férfi & 3 & 3 & 2 & 0,666667 \\
\hline MOGYE & Fogorvos & $\begin{array}{l}25 \text { vagy idősebb } \\
\text { Összesen }\end{array}$ & Nő & $\begin{array}{c}7 \\
46 \\
\end{array}$ & $\begin{array}{c}4 \\
34 \\
\end{array}$ & $\begin{array}{c}5 \\
33 \\
\end{array}$ & $\begin{array}{c}1,25 \\
0,970588\end{array}$ \\
\hline $\begin{array}{l}\text { MOGYE } \\
\text { MOGYE }\end{array}$ & $\begin{array}{l}\text { Gyógyszerész } \\
\text { Gyógyszerész }\end{array}$ & $\begin{array}{l}24 \text { vagy fiatalabb } \\
25 \text { vagy idősebb }\end{array}$ & $\begin{array}{l}\text { Férfi } \\
\text { Férfi }\end{array}$ & $\begin{array}{l}5 \\
2\end{array}$ & 4 & 5 & 1,25 \\
\hline $\begin{array}{l}\text { MOGYE } \\
\text { MOGYE }\end{array}$ & $\begin{array}{l}\text { Gyógyszerész } \\
\text { Gyógyszerész }\end{array}$ & $\begin{array}{l}24 \text { vagy fiatalabb } \\
25 \text { vagy idősebb } \\
\text { Összesen }\end{array}$ & $\begin{array}{l}\text { Nő } \\
\text { Nö }\end{array}$ & $\begin{array}{c}39 \\
5 \\
51 \\
\end{array}$ & 33 & 32 & $\begin{array}{c}0,969697 \\
1\end{array}$ \\
\hline MOGYE & Nővér & 24 vagy fiatalabb & Férfi & 4 & 2 & 3 & 1,5 \\
\hline MOGYE & Nővér & 24 vagy fiatalabb & Nő & 27 & 19 & 20 & 1,052632 \\
\hline MOGYE & Nővér & 25 vagy idősebb & Férfi & 0 & 0 & 0 & 0 \\
\hline MOGYE & Nővér & $\begin{array}{l}25 \text { vagy idősebb } \\
\text { Összesen }\end{array}$ & Nő & $\begin{array}{c}0 \\
31 \\
\end{array}$ & $\begin{array}{c}0 \\
21 \\
\end{array}$ & $\begin{array}{c}0 \\
23 \\
\end{array}$ & $\begin{array}{c}0 \\
1,095238 \\
\end{array}$ \\
\hline BodP & Nővér & 24 vagy fiatalabb & Férfi & 2 & 1 & 1 & 1 \\
\hline BodP & Nővér & 24 vagy fiatalabb & Nő & 24 & 14 & 18 & 1,285714 \\
\hline BodP & Nővér & 25 vagy idősebb & Férfi & 0 & 0 & 0 & 0 \\
\hline BodP & Nővér & $\begin{array}{l}25 \text { vagy idősebb } \\
\text { Összesen }\end{array}$ & Nő & $\begin{array}{c}5 \\
31 \\
\end{array}$ & $\begin{array}{c}2 \\
17 \\
\end{array}$ & $\begin{array}{c}4 \\
23 \\
\end{array}$ & $\begin{array}{c}2 \\
1,352941 \\
\end{array}$ \\
\hline LuisP & Nővér & 24 vagy fiatalabb & Férfi & 5 & 3 & 4 & 1,333333 \\
\hline LuisP & Nővér & 24 vagy fiatalabb & Nő & 29 & 26 & 21 & 0,807692 \\
\hline LuisP & Nővér & 25 vagy idősebb & Férfi & 2 & 3 & 1 & 0,333333 \\
\hline LuisP & Nővér & $\begin{array}{l}25 \text { vagy idősebb } \\
\text { Összesen }\end{array}$ & Nő & $\begin{array}{l}12 \\
48\end{array}$ & $\begin{array}{c}9 \\
41\end{array}$ & $\begin{array}{c}9 \\
35\end{array}$ & $\begin{array}{c}1 \\
0,853659\end{array}$ \\
\hline \multicolumn{4}{|c|}{ Összesen } & 345 & 251 & 252 & \\
\hline
\end{tabular}


2. melléklet: Referenciacsoport súlyai

\begin{tabular}{|c|c|c|c|c|c|c|c|}
\hline & Szak & Kora & Neme & $\begin{array}{l}\text { Teljes } \\
\text { nép. }\end{array}$ & Minta & $\begin{array}{c}\text { Elméleti } \\
\text { gyakoriság }\end{array}$ & Súly \\
\hline & Általános & & & & & & \\
\hline MOGYE & $\begin{array}{l}\text { orvos } \\
\text { Általános }\end{array}$ & & Férfi & 43 & 6 & 14 & 2,333333 \\
\hline MOGYE & orvos & & Nő & 98 & 40 & 31 & 0,775 \\
\hline MOGYE & & Összesen & & 141 & 47 & 45 & 0,957447 \\
\hline MOGYE & Fogorvos & & Férfi & 15 & 2 & 5 & 2,5 \\
\hline MOGYE & Fogorvos & & Nő & 39 & 9 & 12 & 1,333333 \\
\hline MOGYE & & Összesen & & 54 & 11 & 17 & 1,545455 \\
\hline MOGYE & Gyógyszerész & & Férfi & 7 & 3 & 2 & 0,666667 \\
\hline MOGYE & Gyógyszerész & & Nő & 34 & 14 & 11 & 0,785714 \\
\hline MOGYE & & Összesen & & 41 & 17 & 13 & 0,764706 \\
\hline & $\ddot{O} s s$ & esen & & 236 & 75 & 75 & \\
\hline
\end{tabular}




\section{KÉRDŐÍV}

Ez a kutatás az erdélyi magyar végzős orvostan-, fogorvos-, nővér-, illetve gyógyszerészhallgatók külföldi munkavállalási hajlandóságát vizsgálja. Kérlek, figyelmesen olvasd el a kérdéseket és kövesd az utasításokat.

A válaszadás önkéntes és névtelen.

1. Hallgatott szak:

2. Mennyire vagy elégedett az itt kapott szakmai képzéssel? (Karikázd be azt az egyet, amelyik a leginkább jellemző rád)

1. Nagyon elégedetlen vagyok

2. Inkább elégedetlen vagyok

3. Elégedett vagyok meg nem is

4. Többnyire elégedett vagyok

5. Teljesen elégedett vagyok

3. Mire szeretnél szakosodni?

4. Miért éppen arra? Válaszd ki azt az egy okot, amelyik téged leginkább motivál!

1. Jól lehet keresni vele

2. Hiányszakma

3. Mindig is erre vágytam, elhívatásomnak érzem

4. Ismertem ilyen orvost, és mindig felnéztem rá azért, amit tett

5. Összeegyeztethető a nö/feleség/anya szereppel

6. Egyéb, éspedig:.

5. Gondoltál-e már arra, hogy külföldön vállalj munkát?

1. Sosem gondoltam rá

2. Megfordult már a fejemben

3. Többször is gondoltam rá

4. Komolyan fontolgattam/fontolgatom a dolgot

6. Tervezed-e, hogy külföldön dolgozol?

1. Biztosan nem A 7-es kérdés megválaszolása után ugorj a 17-es kérdésre

2. Kevéssé tartom valószínünek

3. Valószínüleg igen, de előbb itthon próbálkozom

4. Nagyon valószínünek tartom

5. Biztosan igen (Ugorj a 8-as kérdésre)

6. Még nem döntöttem el 
7. Miért NEM vállalnál munkát külföldön? Három válaszlehetőség is megjelölhetö.

1. Családom miatt

2. A szülöföldemen szeretnék maradni, ez az otthonom

3. Tudásommal a kisebbségi magyarokat szeretném szolgálni; felelősnek érzem magam miattuk

4. Itthon is meg lehet élni, és közel vannak azok, akiket szeretek

5. A jó szakember itthon is érvényesül

6. Már tudom hol fogok dolgozni; megvan itthon a munkahelyem

8. Mikor mennél el?

1. Rögtön diplomázás után, rezidens vizsga elött

2. A rezidens évek alatt

3. Szakorvosként

4. Még nem tudom

9. Melyik országba mennél?

1. Magyarország

2. Németország

3. Anglia

4. Franciaország

5. Olaszország

6. Skandináv ország, éspedig:

7. Más EU-s ország, éspedig.

8. Amerikai Egyesült Államok

9. Egyéb, éspedig:....

10. Él-e ott valakid?

1. Nem Ugorj a 12-es kérdésre!

2. Igen: családtag, rokon Ugorj a 11-es kérdésre!

3. Igen: barát Folytasd a 10.a./b kérdéssel!

4. Igen: ismerős Ugorj a 11-es kérdésre!

10.a. Külföldön élő barátod nemzetisége:

1. Magyar

2. Nem magyar

10.b. Külföldön élő barátod:

1. Innen elszármazott

2. Ottani/ helybeli

3. Egyéb, éspedig:

11. Hívtak-e ezek az emberek, hogy menj abba az országba, ahol ők élnek?

1. Nem

2. Hívtak, hogy látogassam meg őket

3. Bátorítottak is, hogy keressek ott munkát 
12. Mennyi időre tervezed a külföldi munkavállalást?

1. Ingáznék, az itthoni munkahelyem megtartása mellett

2. Néhány hónap Ugorj a 13-as kérdésre

3. 1-3 év Ugorj a 13-as kérdésre

4. 4-5 év Ugorj a 13-as kérdésre

5. 6-10 év Ugorj a 13-as kérdésre

6. Végleg kitelepülnék Ugorj a 13-as kérdésre

7. Egyéb, éspedig: Ugorj a 13-as kérdésre

12.a. Ha ingáznál, milyen gyakorisággal tennéd azt?

1. Hetente

2. Havonta néhány alkalommal

3. Havonta egyszer

4. Évente néhány alkalommal

5. Nem tudom

13. Miért mennél külföldre dolgozni? A következő tényezők milyen szerepet játszanak ebben? Fontossági sorrendjüknek megfelelően jelöld őket számokkal! 1-gyel jelölt a legfontosabbat és 7-tel a legkevésbé fontosat. Ha a felsoroltakon kívül nincs egyéb tényező, amit említenél, akkor a 7. válaszlehetőség kapja a 7. sorszámot.

1. A román nyelv problémát jelent számomra

2. Magasabb fizetés

3. Jobbak a munkakörülmények

4. Többet tanulhatnék, fejlődhetnék szakmámban

5. Magasabb életszínvonal

6. Nagyobb szakmai presztízs

7. Egyéb, éspedig:

14. Tettél-e már valamilyen lépést a külföldi munkavállalás ügyében? Több válaszlehetőség is megjelölhető!

1. Nem, csak gondolkodtam rajta

2. Igen, interneten gyüjtögettem az információkat arról, hogy milyen iratok szükségesek

3. Személyesen érdeklődtem barátaimtól/ismerőseimtől, akiknek már van ebben tapasztalatuk

4. Már konkrét álláshirdetéseket nézegettem

5. Egyéb, éspedig:.

15. Álláskeresésben honnan szerzed/szereznéd be a szükséges információt? Több válaszlehetőség is megjelölhető!

1. Személyes kapcsolataimon keresztül érdeklődnék

2. E-mailben, levelezölistára érkeznek

3. Interneten rákeresnék

4. Munkaerő-közvetítő irodán keresztül

5. Egyéb, éspedig:. 
16. Milyen feltételek mellett maradnál itthon? Válaszd a számodra legfontosabbakat (max. 3 válaszlehetőség)!

1. Ha nagyobb lenne a fizetés, körülbelül .RON

2. Ha az itthoni rezidens-képzési rendszert megváltoztatnák

3. Ha itthon jobban megbecsülnék a fiatal orvosokat

4. Ha szolgálati lakást biztosítanának

5. Ha a szakmai közeg (idősebb vezető kollégák attitüdje) támogatóbb lenne.

6. Ha a szakmai színvonal jobb lenne

7. Ha jobb munkakörülményeket és felszerelést biztosítanának

8. Egyéb, éspedig:

17. Mennyiben értesz egyet az alábbi kijelentésekkel? (Minden sorban karikázz egyet!)

\begin{tabular}{|c|c|c|c|c|c|}
\hline & $\begin{array}{l}\text { Egyáltalán } \\
\text { nem értek } \\
\text { egyet }\end{array}$ & $\begin{array}{l}\text { Inkább } \\
\text { nem értek } \\
\text { egyet }\end{array}$ & $\begin{array}{l}\text { Egyetértek } \\
\text { meg nem } \\
\text { is }\end{array}$ & $\begin{array}{l}\text { Többnyire } \\
\text { egyetértek }\end{array}$ & $\begin{array}{l}\text { Teljesen } \\
\text { egyetértek }\end{array}$ \\
\hline $\begin{array}{l}\text { Ebben az országban a } \\
\text { fiataloknak nincs } \\
\text { jövője }\end{array}$ & 1 & 2 & 3 & 4 & 5 \\
\hline $\begin{array}{l}\text { A magyarok itt mindig } \\
\text { hátrányos helyzetben } \\
\text { lesznek }\end{array}$ & 1 & 2 & 3 & 4 & 5 \\
\hline $\begin{array}{lr}\text { Külföldön a nöknek } \\
\text { több esélyük } & \text { van } \\
\text { egyes } & \text { orvosi } \\
\text { szakterületeken } & \\
\text { elhelyezkedni, mint } \\
\text { itthon }\end{array}$ & 1 & 2 & 3 & 4 & 5 \\
\hline $\begin{array}{l}\text { Kezdőorvosként az } \\
\text { ember itthon képtelen } \\
\text { eltartani a családját }\end{array}$ & 1 & 2 & 3 & 4 & 5 \\
\hline $\begin{array}{l}\text { A hálapénz szüksséges } \\
\text { rossz, amire az } \\
\text { orvosoknak szükségük } \\
\text { van a rendes } \\
\text { megélhetéshez }\end{array}$ & 1 & 2 & 3 & 4 & 5 \\
\hline $\begin{array}{lr}\text { Ha legalább feleannyit } \\
\text { keresnék, } & \text { mint } \\
\text { nyugaton az } & \text { orvosok, } \\
\text { biztosan } & \text { itthon } \\
\text { maradnék } & \end{array}$ & 1 & 2 & 3 & 4 & 5 \\
\hline
\end{tabular}

18. Nemed

1. Férfi

2. Nö

19. Születési éved: 
20. Családi állapotod

1. Nötlen/hajadon

2. Házas

3. Nem együttélő párkapcsolata van

4. Együtt él nem házasságban

5. Elvált

6. Özvegy

21. Mi szüleid legmagasabb iskolai végzettsége? Jelöld x-szel mindkét oszlopban!

1. Kevesebb, mint 8 osztály

2. Általános 8 évfolyam

3. Szakiskola (érettségi nélkül)

4. Szakközépiskola (érettségivel)

5. Elméleti líceumi érettségi

6. Technikum/poszliceális

7. Föiskola, egyetem

8. Posztgraduális (mesteri,

\begin{tabular}{|l|l|}
\hline Édesapád & Édesanyád \\
\hline & \\
\hline & \\
\hline & \\
\hline & \\
\hline & \\
\hline & \\
\hline & \\
\hline & \\
\hline
\end{tabular}
doktori)

22. Megítélésed szerint milyen a szüleid anyagi helyzete?

5. Gondok nélkül élnek

4. Beosztással jól kijönnek

3. Éppen, hogy kijönnek a havi jövedelmükből

2. Hónapró-hónapra anyagi gondjaik vannak

1. Nélkülözések között élnek

23. Hol helyeznéd el szüleidet anyagi helyzetük alapján az alábbi skálán, ahol a 0 a nagyon szegényt, a 10 pedig a nagyon gazdagot jelenti? Karikázd be azt a számot!

Nagyon szegény

Nagyon gazdag

$\begin{array}{lllllllllll}0 & 1 & 2 & 3 & 4 & 5 & 6 & 7 & 8 & 9 & 10\end{array}$

24. Mi édesapád foglalkozása? Ha nyugdíjas, az utolsó foglalkozását vedd alapul!

1. Önálló gazdálkodó, őstermelő

2. Fizikai munkát is végző kisvállalkozó

3. Szellemi szabadfoglalkozású

4. Egyéb vállalkozó/önálló

5. Felső vagy középszintü vezetői alkalmazott

6. Alsó szintü vezetői vagy művezetői alkalmazott

7. Diplomához kötött szellemi alkalmazott

8. Szakmunkás

9. Betanított vagy segédmunkás

10. Háztartásbeli

11. Egyéb, éspedig: 
25. Mi édesanyád foglalkozása? Ha nyugdíjas, az utolsó foglalkozását vedd alapul!

1. Önálló gazdálkodó, őstermelő

2. Fizikai munkát is végző kisvállalkozó

3. Szellemi szabadfoglalkozású

4. Egyéb vállalkozó/önálló

5. Felső vagy középszintü vezetöi alkalmazott

6. Alsó szintü vezetői vagy müvezetői alkalmazott

7. Diplomához kötött szellemi alkalmazott

8. Szakmunkás

9. Betanított vagy segédmunkás

10. Háztartásbeli

11. Egyéb, éspedig:.

26. Van-e saját lakóingatlanod?

1. Van

2. Nincs

27. A következö állítások közül hozzád melyik áll a legközelebb?

1. Mindenkinek annyit kellene kapnia a társadalomtól, mint amennyivel hozzájárul a müködéséhez

2. Mindenkinek egyenlö arányban kell részesednie a megtermelt javakból

3. Mindenki a legjobb képességei alapján járuljon hozzá a társadalom fenntartásához, és annyit kapjon, amennyire szüksége van

28. És te hogyan ítéled meg saját helyzetedet jövőbeni orvosként az alábbi skálán? Összességében többet kapsz a társadalomtól, mint amennyivel hozzájárulsz a közös kiadásokhoz, vagy többel járulsz hozzá, mint amennyit kapsz?

Sokkal többet kap, mint amennyivel hozzájárul

$\begin{array}{lllllllllll}0 & 1 & 2 & 3 & 4 & 5 & 6 & 7 & 8 & 9 & 10\end{array}$

Sokkal többel járul hozzá mint amennyit kap 10

29. Hogyan jellemeznéd magad?

1. Jó tanuló vagyok

2. Közepes tanuló vagyok

3. Gyengén teljesítő tanuló vagyok

30. Milyen idegen nyelv(ek)en beszélsz és milyen szinten?

\begin{tabular}{|l|l|l|l|}
\hline & Angol & & \\
\hline Felsőfokú nyelvvizsgám van & & & \\
\hline Középfokú nyelvvizsgám van nyelvvizsgám, de & & & \\
\hline $\begin{array}{l}\text { Nincs nó } \\
\text { folyékonyan beszélem a nyelvet }\end{array}$ & & & \\
\hline $\begin{array}{l}\text { Alapszinten megértem és meg } \\
\text { tudom értetni magam }\end{array}$ & & & \\
\hline
\end{tabular}


31. Szoktál-e idegen nyelvü...?

\begin{tabular}{|l|l|l|l|l|l|l|}
\hline & Nem & Naponta & Hetente & Havonta & $\begin{array}{l}\text { Évente } \\
\text { néhányszor }\end{array}$ & $\begin{array}{l}\text { Milyen } \\
\text { nyelv(ek)en }\end{array}$ \\
\hline $\begin{array}{l}\text { Szakfolyóiratot } \\
\text { olvasni }\end{array}$ & & & & & & \\
\hline $\begin{array}{l}\text { Folyóiratot, } \\
\text { napilapot olvasni }\end{array}$ & & & & & & \\
\hline $\begin{array}{l}\text { Híreket } \\
\text { nézni/hallgatni }\end{array}$ & & & & & & \\
\hline
\end{tabular}

32. Mennyire vagy elégedett eddigi életeddel? Jelöld az alábbi skálán, ahol a 0 a nagyon elégedetlen, a 10 pedig a nagyon elégedettet jelenti!

Nagyon elégedetlen

Teljesen

elégedett

$\begin{array}{lllllllllll}0 & 1 & 2 & 3 & 4 & 5 & 6 & 7 & 8 & 9 & 10\end{array}$

Köszönöm a segítséged! :) 
4. melléklet: Átlagos éves bérek a célországokban (1990-2013)

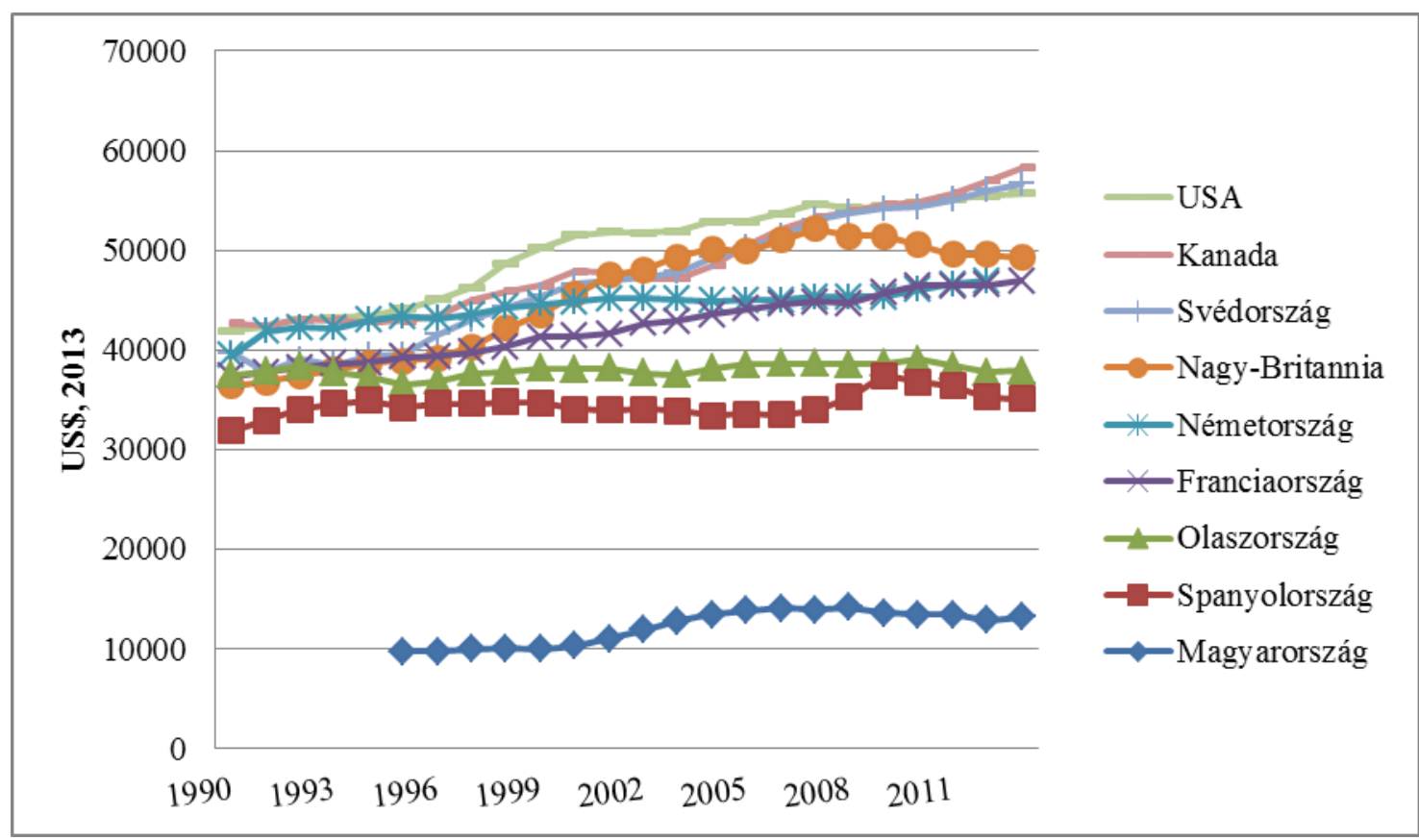

Forrás: Average annual wages (OECD Statistics 2014)

5. melléklet: Honositások száma

\begin{tabular}{|c|c|c|c|}
\hline $\begin{array}{l}\text { Honositás } \\
\text { éve }\end{array}$ & Románia & $\begin{array}{c}\text { Ebböl MOGYE } \\
(\%)\end{array}$ & $\begin{array}{c}\text { Elismertetések } \\
\text { száma }\end{array}$ \\
\hline 1990 & 384 & 78 & \\
\hline 1991 & 422 & 78 & \\
\hline 1992 & 197 & 73 & \\
\hline 1993 & 40 & 58 & \\
\hline 1994 & 55 & 69 & \\
\hline 1995 & 21 & 57 & \\
\hline 1996 & 11 & 73 & \\
\hline 1997 & 25 & 84 & \\
\hline 1998 & 37 & 68 & \\
\hline 1999 & 16 & 69 & \\
\hline 2000 & 88 & 76 & \\
\hline 2001 & 52 & 71 & \\
\hline 2002 & 101 & 63 & \\
\hline 2003 & 121 & 67 & \\
\hline 2004 & 133 & 68 & \\
\hline 2005 & 169 & 67 & \\
\hline 2006 & 141 & 72 & \\
\hline 2007 & 110 & 58 & \\
\hline 2008 & 50 & 62 & \\
\hline 2009 & 33 & 15 & 45 \\
\hline 2010 & 20 & 0 & 18 \\
\hline 2011 & 39 & 13 & 34 \\
\hline 2012 & 43 & 16 & 36 \\
\hline Összesen & 2308 & 68 & 133 \\
\hline
\end{tabular}

Forrás: EEKH adatai 
Megj.: az elismertetés az EU-konform diplomákat foglalja magában, amiket a Román Oktatási Minisztérium bocsát ki, és ebböl nem derül ki, hogy mely egyetemen szerezte az áttelepült a diplomáját. Az ezekben az években honositott diplomák tulajdonosai $2007-$ nél korábban szerezték meg oklevelüket.

6. melléklet: MOGYE-n végzett magyar tannyelvü hallgatók (asszisztensek nélkül) és a honositottak száma

\begin{tabular}{ccc}
$\begin{array}{c}\text { Honositás } \\
\text { éve }\end{array}$ & Románia & $\begin{array}{c}\text { Magyar nyelvü } \\
\text { végzös }\end{array}$ \\
\hline 1990 & 384 & 98 \\
1991 & 422 & 58 \\
1992 & 197 & 59 \\
1993 & 40 & 38 \\
1994 & 55 & 28 \\
1995 & 21 & 59 \\
1996 & 11 & 74 \\
1997 & 25 & 113 \\
1998 & 37 & 102 \\
1999 & 16 & 117 \\
2000 & 88 & 119 \\
2001 & 52 & 115 \\
2002 & 101 & 148 \\
2003 & 121 & 148 \\
2004 & 133 & 191 \\
2005 & 169 & 198 \\
2006 & 141 & 180 \\
2007 & 110 & 152 \\
2008 & 50 & 171 \\
2009 & 33 & $181 *$ \\
2010 & 20 & $212 *$ \\
2011 & 39 & $234 *$ \\
2012 & 43 & $214 *$ \\
\hline$\ddot{O} s s z e s e n$ & 2308 & 3009 \\
Forrás: EEKH és MOGYE által nyújtott adatok
\end{tabular}

*Saját becslésen alapuló adatok (hivatalos információk hiányában), melyek kiszámításánál a megelözö években végzett magyar hallgatói arányszámokat vettem figyelembe 
7. melléklet: Honositottak száma szakonként

\begin{tabular}{llc} 
Szak & \multicolumn{1}{c}{ Nem } & $N$ \\
\hline Orvos & Férfi & 736 \\
& Nö & 942 \\
\multirow{2}{*}{ Fogorvos } & Összesen & 1678 \\
& Férfi & 163 \\
& Nő & 211 \\
Gyógyszerész & Összesen & 374 \\
& Férfi & 43 \\
& Nő & 212 \\
& Összesen & 255 \\
\hline & Összesen & 2307
\end{tabular}

Forrás: EEKH adatai

8. melléklet: Származás hatása a migrációs tervekere a vizsgálati- és referencia csoportban

\begin{tabular}{lcc}
\multicolumn{3}{c}{ Tervez külföldi munkavállalást (\%) } \\
Magyar & $\begin{array}{c}\text { Román } \\
\text { tannyelvü }\end{array}$ & tannyelvü \\
Szülök státusa foglalkozás alapján & 64 & 55 \\
Alacsonyabb & 54 & 78 \\
Vegyes & 69 & 62 \\
Magasabb & 139 & 66
\end{tabular}

Forrás: Saját adatok 
9. melléklet: Fürtelemzés

\begin{tabular}{|c|c|c|c|c|c|c|c|c|c|c|c|c|c|c|c|c|c|c|c|c|}
\hline & $\mathrm{N}$ & Q & $\mathrm{E}$ & $\mathrm{R}$ & $\mathrm{K}$ & $\mathrm{H}$ & A & B & $\mathrm{G}$ & $\mathrm{F}$ & $\mathrm{L}$ & $\mathrm{I}$ & $\mathrm{M}$ & $\mathrm{S}$ & $\mathrm{T}$ & $\mathrm{P}$ & $\mathrm{O}$ & $\mathrm{J}$ & $\mathrm{D}$ & $\mathrm{C}$ \\
\hline \multicolumn{21}{|l|}{ Motivációk } \\
\hline Kényszer & $\cdot$ & & $\cdot$ & & & & & - & & & & & & & & & $\cdot$ & & & $\bullet$ \\
\hline Megváltozott referencia-alap & & & & - & & & & & & & & & & & & & & $\cdot$ & - & \\
\hline Anyagi jobblét & & & & - & & & - & $\cdot$ & & $\cdot$ & & & & • & & & & $\bullet$ & - & $\bullet$ \\
\hline Kapcsolat-vezérelt migráció & & & & & $\bullet$ & & & & & & & & & & & $\bullet$ & & & & \\
\hline Mintakövetés & & & & - & & & & & & - & & & & & & & & & & $\bullet$ \\
\hline Kalandvágyó & & & & & & & & & & & & & & & $\cdot$ & & & & & \\
\hline Szakmai/ hazai eü. rendszer & & & & - & & $\bullet$ & & - & & & & & & - & & - & - & & & $\bullet$ \\
\hline Tudatosan maradni szándékozó & & - & & & & & - & & - & & - & $\bullet$ & - & & & & & & & \\
\hline \multicolumn{21}{|l|}{ Identitás } \\
\hline Egyéni érdekkövető & & & & $\bullet$ & & $\bullet$ & & $\cdot$ & & & $\bullet$ & & & $\cdot$ & & & - & $\bullet$ & $\bullet$ & $\bullet$ \\
\hline Kollektív felelősségvállaló & & & - & & & & - & & - & & & & & & & & & & & \\
\hline Csapdába szorult & & & & & - & & & & & & & & & & $\cdot$ & $\cdot$ & & & & \\
\hline Megállapodott/Elégedett & $\bullet$ & $\bullet$ & & & & & & & & - & & - & $\cdot$ & & & & & & & \\
\hline \multicolumn{21}{|l|}{ Narratíva } \\
\hline Aktív & $\cdot$ & $\bullet$ & - & - & & $\bullet$ & & - & - & - & & $\bullet$ & $\cdot$ & $\cdot$ & $\cdot$ & $\cdot$ & - & - & & $\bullet$ \\
\hline Passzív & & & & & - & & - & & & & - & & & & $\cdot$ & $\cdot$ & & - & $\bullet$ & \\
\hline \multicolumn{21}{|l|}{ Családi származás } \\
\hline Mobil & $\cdot$ & $\bullet$ & - & - & - & $\bullet$ & $\bullet$ & & & & & & & & & & & & & \\
\hline Státusmegőrző & & & & & & & & & & & & & - & - & & $\cdot$ & $\bullet$ & - & $\cdot$ & $\bullet$ \\
\hline Vegyes & & & & & & & & - & - & - & $\bullet$ & $\bullet$ & & & $\cdot$ & & & & & \\
\hline \multicolumn{21}{|l|}{ Kapcsolat } \\
\hline Egyedülálló & & & $\bullet$ & & & $\bullet$ & & $\bullet$ & & & $\bullet$ & & & & $\cdot$ & & & & & \\
\hline Párkapcsolat & $\bullet$ & & & - & $\bullet$ & & & & - & & & & $\bullet$ & & & $\bullet$ & - & & - & \\
\hline Házas & & & & & & & & & & & & - & & $\cdot$ & & & & $\bullet$ & & $\bullet$ \\
\hline \multicolumn{21}{|l|}{ Célország } \\
\hline Magyarország & & & & & & & & & & & & & & & & $\cdot$ & $\bullet$ & & $\bullet$ & \\
\hline Németország & $\bullet$ & & - & & $\bullet$ & & & $\cdot$ & & & & & & - & & & & & & $\bullet$ \\
\hline Anglia & $\bullet$ & & & - & & $\bullet$ & & $\bullet$ & & & & & & & & & & & & \\
\hline
\end{tabular}




\begin{tabular}{|c|c|c|c|c|c|c|c|c|c|c|c|c|c|c|c|c|c|c|c|c|}
\hline Skandináv államok & & & & & & & & & & & & & & & & & - & & $\bullet$ & \\
\hline angol nyelvterület & & & & & $\bullet$ & & & & & & $\bullet$ & & & & $\bullet$ & & & $\bullet$ & & \\
\hline Franciaország & & & & $\bullet$ & $\bullet$ & & & & & & & & & & & & & & & \\
\hline \multicolumn{21}{|l|}{ Időzítés } \\
\hline Közvetlenül diplomázás után & & & & & & & & $\bullet$ & & & & & & $\bullet$ & $\bullet$ & & & & $\bullet$ & \\
\hline Itthoni próbálkozás után & $\bullet$ & & $\bullet$ & & & & $\bullet$ & & & & & & & & & $\bullet$ & $\bullet$ & & & $\bullet$ \\
\hline Itthoni tapasztalatszerzés után & & & & $\bullet$ & $\bullet$ & $\bullet$ & & & & $\bullet$ & & & & & & & & $\bullet$ & & \\
\hline \multicolumn{21}{|l|}{ Kivel? } \\
\hline Egyedül & & & & & & & $\bullet$ & $\bullet$ & & & & & & & & & $\bullet$ & & $\bullet$ & \\
\hline Párjával/házastársával & $\bullet$ & & & - & - & $\bullet$ & & & & - & & & & $\bullet$ & & - & & - & & $\bullet$ \\
\hline Baráttal & & & $\bullet$ & & & & & & & & $\bullet$ & & & & $\bullet$ & & & & & \\
\hline \multicolumn{21}{|l|}{ Kapcsolati tőke } \\
\hline Családi/rokoni kapcsolatok & & & $\bullet$ & & & $\bullet$ & $\bullet$ & $\bullet$ & $\bullet$ & $\bullet$ & $\bullet$ & $\bullet$ & & $\bullet$ & & $\bullet$ & $\bullet$ & $\bullet$ & $\bullet$ & \\
\hline Kollegiális/baráti kapcsolatok & & $\bullet$ & $\bullet$ & & & $\bullet$ & & & $\bullet$ & & & $\bullet$ & & $\bullet$ & & $\bullet$ & $\bullet$ & & & \\
\hline Más baráti kapcsolatok & & $\bullet$ & $\bullet$ & & & & & & & & & & $\bullet$ & & & & $\bullet$ & & & \\
\hline Ismerősök & & & & & & & & & & & & & & & $\bullet$ & & & & $\bullet$ & $\bullet$ \\
\hline Anyagi nehézségek említése & & & $\bullet$ & $\bullet$ & & $\bullet$ & $\bullet$ & & $\bullet$ & & & & & & & & & & & \\
\hline \multicolumn{21}{|l|}{ Nemzetisége } \\
\hline Román & & & & - & - & - & $\bullet$ & $\bullet$ & & - & - & - & - & $\bullet$ & & & & & & \\
\hline Magyar & $\bullet$ & $\bullet$ & $\bullet$ & & & & & & $\bullet$ & & & & & & $\bullet$ & $\bullet$ & $\bullet$ & $\bullet$ & $\bullet$ & $\bullet$ \\
\hline \multicolumn{21}{|l|}{ Időtartam } \\
\hline Rövid távú ( $\leq 3$ év) & & & $\bullet$ & & & & $\bullet$ & & & & & & & & $\bullet$ & & & & & \\
\hline Közép távú (4-5 év) & & & & & & & & & & & & & & $\bullet$ & & $\bullet$ & $\bullet$ & & $\bullet$ & \\
\hline Hosszú távú ( $\geq 6$ év) & & & & $\bullet$ & & $\bullet$ & & & & & & & & & & & & & & $\bullet$ \\
\hline Végleg & & & & $\bullet$ & & & & & & & & & & & & & & $\bullet$ & & \\
\hline Jobb anyagi körülmények & $\bullet$ & & $\bullet$ & $\bullet$ & & $\bullet$ & $\bullet$ & $\bullet$ & $\bullet$ & $\bullet$ & $\bullet$ & $\bullet$ & $\bullet$ & $\bullet$ & $\bullet$ & & & $\bullet$ & $\bullet$ & $\bullet$ \\
\hline Szakmai fejlődés & & $\bullet$ & $\bullet$ & & & $\bullet$ & & & $\bullet$ & $\bullet$ & & & & $\bullet$ & & & $\bullet$ & $\bullet$ & $\bullet$ & \\
\hline Más rendszer & & & & $\bullet$ & $\bullet$ & & $\bullet$ & & & & & & & & & & & & & $\bullet$ \\
\hline Jobb munkakörülmények, eszközök & $\bullet$ & & & & & $\bullet$ & & & $\bullet$ & & & & & $\bullet$ & & & $\bullet$ & $\bullet$ & $\bullet$ & \\
\hline Más attitűd/ Meritokrácia/Megbecs. & & & & & $\bullet$ & $\bullet$ & $\bullet$ & & $\bullet$ & & $\bullet$ & $\bullet$ & & & $\bullet$ & $\bullet$ & & $\bullet$ & & $\bullet$ \\
\hline Magasabb életszínvonal & & & & & & & & & & & & $\bullet$ & & & & & & & & \\
\hline Más tapasztalatok & & & & & & & & & & & & & & & $\bullet$ & $\bullet$ & & & & \\
\hline
\end{tabular}




\begin{tabular}{|c|c|c|c|c|c|c|c|c|c|c|c|c|c|c|c|c|c|c|c|c|}
\hline \multicolumn{21}{|l|}{ Hátrányai } \\
\hline Távol családtól, otthontól & - & - & - & - & - & - & - & - & - & - & - & & - & - & - & & - & & - & - \\
\hline Idegenség & & & $\bullet$ & - & & & & $\cdot$ & $\bullet$ & $\bullet$ & & • & & & $\cdot$ & - & & & & \\
\hline Kommunikáció/nyelvi nehézségek & & & & - & & & - & $\bullet$ & & & & & & - & - & & - & & & - \\
\hline Kapcsolatok átértékelődése & & $\bullet$ & $\bullet$ & & & & & & $\bullet$ & & & & & & & & & & & \\
\hline Alkalmazkodás/beilleszkedés/diszkr. & & & & - & - & - & - & - & & - & & & & - & & - & - & & - & - \\
\hline Kudarc/malpraxis & & & & & & $\bullet$ & & $\cdot$ & & & & & & & - & & & & & \\
\hline \multicolumn{21}{|l|}{ Jövőkép } \\
\hline Itthon & - & $\bullet$ & • & & - & $\bullet$ & $\bullet$ & & $\bullet$ & & • & • & - & & $\bullet$ & & - & - & - & • \\
\hline Külföldön & & & & - & & & & & & & & & & - & & & & & & \\
\hline Nem tudja & & & & & & & & & & & & & & & & - & & & & \\
\hline \multicolumn{21}{|l|}{ Pályaválasztás } \\
\hline Mintakövetés & & & $\bullet$ & - & & $\bullet$ & & $\bullet$ & & & - & - & $\bullet$ & $\bullet$ & & & - & & - & - \\
\hline Egyetlen lehetőség/váratlan döntés & & - & & & & & - & & & - & & & & & - & & - & & & \\
\hline Gyerekkori hajlam & - & & & - & & & & $\bullet$ & & & & & & & & & & & & \\
\hline Segíteni akarás/betegség & & & - & & - & & & - & - & & & & & & & - & - & & & \\
\hline Tanács & & & & & • & & & & & & - & & & - & & & & - & - & \\
\hline Ambíció & & & & & & & & & & & & & & & - & - & & & & \\
\hline
\end{tabular}


10. melléklet: Migráns interjúalanyok jegyzéke

AO: férfi, orvos

BA: férfi, orvos

EP: nő, nővér

GL: nő, orvos

HR: nő, fogorvos

KE: nö, orvos

LP: nő, nővér

MJ: nő, orvos

NE: nö, orvos

ON: férfi, orvos

RI: nő, fogorvos

RT: nő, orvos

TC: nő, orvos

ZS: férfi, orvos

11. melléklet: Végzős hallgatók interjúalanyainak jegyzéke

A: nő, nővér, román nyelvü

B: nő, nővér, román nyelvű

C: férfi, orvos, magyar nyelvü

D: nö, fogorvos, magyar nyelvü

E: nő, nővér, magyar nyelvü

F: nő, fogorvos, román nyelvü

G: nő, orvos, magyar nyelvü

H: nő, fogorvos, román nyelvü

I: nö, fogorvos, román nyelvü

$\mathrm{J}$ : nő, fogorvos, magyar nyelvü

K: nő, gyógyszerész, román nyelvü

L: nő, gyógyszerész, román nyelvü

M: nő, gyógyszerész, román nyelvü

$\mathrm{N}$ : nő, nővér, magyar nyelvü

$\mathrm{O}$ : nő, gyógyszerész, magyar nyelvü

P: nő, orvos, magyar nyelvü

Q: nő, gyógyszerész, magyar nyelvü

R: nő, orvos, román nyelvü

S: férfi, orvos, román nyelvü

T: nő, gyógyszerész, magyar nyelvü 


\section{Magyar nyelvü tanulmányok:}

Pitó K., 2009. Elmennél, nem mennél?... Erdélyi magyar tizenévesek migrációs kultúrája. Új Ifjúsági Szemle, 7 (2), pp. 5-20. Available at:

http://www.uisz.hu/archivum/uisz_23 pito.pdf

Székely L. \& Pitó K., 2010. Nélkülük megy a vonat tovább? Mobilitási történet és hajlandóság a magyarországi fiatalok körében. Új Ifjúsági Szemle, 8 (2), pp. 11-35.

Pitó K., 2015. „Nálunk (...) minden ötödik órában elhagyja az országot egy orvos”. Tér és Társadalom, 29 (3), pp. 93-114

doi: 10.17649/TET.29.3.2683

\section{Konferencián bemutatott anyag:}

Pitó K., 2013. A Marosvásárhelyi Orvosi és Gyógyszerészeti Egyetem migrációs potenciálja. In Koncz I. \& Nagy E. (eds.) Tudományos próbapálya címü nemzetközi Ph.D. konferencia elöadásai. Budapest: Professzorok az Európai Magyarországért, pp. 68-78.

(http://peme.hu/userfiles/Interdiszciplin $\% \mathrm{C} 3 \% \mathrm{~A} 1$ lis $\% 20 \% \mathrm{C} 3 \% \mathrm{~A} 9 \mathrm{~s} \% 20$ tudom $\% \mathrm{C} 3 \% \mathrm{~A}$ $\underline{\text { nyfiloz } \% \mathrm{C} 3 \% \mathrm{~B} 3 \text { fia.pdf) }}$

\section{Idegen nyelvü tanulmány:}

Pitó K., 2015. The Migration Potential of Graduates at a Medical School in Romania: Does Minority Status Matter? A Qualitative Approach. Corvinus Journal of Sociology and Social Policy, 6, pp. 129-151.

http://doi.org/6fq 